\author{
UNIVERSIDADE DE SÃO PAULO \\ FACULDADE DE ARQUITETURA E URBANISMO
}

PAULA REGINA DA CRUZ NOIA

\title{
Sustentabilidade socioambiental: Desenvolvimento de sistemas construtivos em bambu no Vale do Ribeira, SP.
}

\author{
Dissertação de mestrado apresentada ao curso de \\ pós-graduação da Faculdade de Arquitetura e \\ Urbanismo da Universidade de São Paulo, para a \\ obtenção do título de mestre em Arquitetura e \\ Urbanismo. \\ Área de concentração: Tecnologia da Arquitetura. \\ Orientadora: Prof.. Dra. Erica Yukiko Yoshioka. \\ Projeto realizado com o apoio da FAPESP - Fundação \\ de amparo à pesquisa do Estado de São Paulo. \\ EXEMPLAR REVISADO E ALTERADO EM RELAÇÃO À \\ VERSÃO ORIGINAL, SOB RESPONSABILIDADE DO \\ AUTOR E ANUÊNCIA DO ORIENTADOR. \\ O original se encontra disponível na sede do \\ programa
}

São Paulo, 30 de Dezembro de 2012 
AUTORIZO A REPRODUÇÃO E DIVULGAÇÃO TOTAL OU PARCIAL DESTE TRABALHO, POR QUALQUER MEIO CONVENCIONAL OU ELETRÔNICO, PARA FINS DE ESTUDO E PESQUISA, DESDE QUE CITADA A FONTE.

E-MAIL: paula.noia@usp.br

Noia, Paula Regina da Cruz

N782s Sustentabilidade socioambiental : desenvolvimento de sistemas construtivos em bambu no Vale do Ribeira, SP /

Paula Regina da Cruz Noia. -- São Paulo, 2012.

211 p. : il.

Dissertação (Mestrado - Área de Concentração : Tecnologia da Arquitetura) - FAUUSP.

Orientadora: Érica Yukiko Yoshioka

1. Arquitetura sustentável - Vale do Ribeira (SP) 2. Sistemas e processos construtivos 3. Bambu 4. Meio ambiente. Título

CDU 72:504(816.12) 
NOIA, Paula Regina da Cruz. Sustentabilidade socioambiental: Desenvolvimento de sistemas construtivos em bambu no Vale do Ribeira, SP. Dissertação de mestrado apresentada ao curso de pós-graduação da Faculdade de Arquitetura e Urbanismo da Universidade de São Paulo, para a obtenção do título de mestre em Arquitetura e Urbanismo.

Aprovado em 03/12/2012

Banca Examinadora:

Prof. Dr. Antonio Ludovico Beraldo - FEAGRI UNICAMP,

Prof. Dr. Reginaldo Luiz Nunes Ronconi - FAU USP,

Profa. Dra. Erica Yukiko Yoshioka - FAU USP (orientadora). 


\section{DEDICATÓRIA}

Aos meus pais, Nemias e Blandina, que sempre me estimularam ao aprendizado autônomo e responsável, criando as bases para a busca incansável pelo conhecimento. 


\section{AGRADECIMENTOS}

Muitos foram aqueles que contribuíram direta e indiretamente para este trabalho, e o processo de troca certamente foi o seu melhor produto.

Primeiramente gostaria de agradecer à Profa. Dr. Erica Yoshioka, minha sempre presente orientadora, cujo profissionalismo e sabedoria tanto me inspiraram ao longo deste processo.

Ao Prof. Dr. Reginaldo Ronconi, pelas ricas trocas de conhecimento, tanto no processo do mestrado quanto no trabalho junto ao Laboratório de Culturas Construtivas (LCC FAU USP).

Ao Prof. Dr. Antonio Beraldo da UNICAMP, pela importante orientação desde a banca de qualificação até a finalização do trabalho, e ao Prof. Dr. Marco Pereira do Laboratório de Experimentação com Bambu da UNESP, pela hospitalidade com a qual fui recebida em seu laboratório.

Aos colegas do Laboratório de Culturas Construtivas: Carlos Guerra, Francisco Barros, Juliano Martins, Micheline Marcos, Tomaz Lotufo e Fernando Minto; presentes na construção diária do tão querido Laboratório de Culturas Construtivas.

Ao Romerito Ferraz, técnico do Canteiro Experimental, pelos inestimáveis ensinamentos à mim concedidos na execução do protótipo. Também a todos os técnicos e funcionários do LAME pela contribuição no mesmo processo, especialmente ao Julio César da Silva, José Rocha e ao Santos, da manutenção.

Ao aluno de graduação Gustavo de Oliveira, pela grande ajuda ao longo da execução do protótipo.

Aos funcionários do Viveiro de mudas da USP, sob a coordenação de Manuel, pelo paciente trabalho de auxílio na extração dos bambus para o protótipo.

Aos funcionários do Departamento de Tecnologia e da Pós-graduação da FAU USP.

À equipe VIDEO FAU, pelo suporte na elaboração do registro visual da execução do protótipo.

À arquiteta Leiko Motomura e ao engenheiro agrônomo Danilo Candia, pelas ricas entrevistas concedidas à pesquisa.

Aos colegas colombianos do Centro de Investigación de Madera y Guadua (CIBAM), do Instituto de Investigaciones Tecnologicas da Universidad Nacional de Colombia (UNAL), pela grande colaboração no período de estágio em pesquisa realizado na instituição. Especialmente à orientação concedida pelo Prof. Jorge Lozano e pelo colega de laboratório engenheiro César Ardilla, fundamental para a compreensão de muitas questões inerentes ao trabalho.

Aos arquitetos e construtores colombianos Simón Vélez e Marcelo Villegas, pela generosa receptividade, inata a todos os colombianos com quem lidei nesse período de aprendizado.

À Fundação de Amparo à Pesquisa do Estado de São Paulo (FAPESP) pela bolsa de mestrado que possibilitou a realização deste trabalho.

Ao Programa Santander de Mobilidade Internacional pela bolsa de estágio em pesquisa de pósgraduação realizado junto à Universidad Nacional de Colombia.

Aos familiares, especialmente meus pais Nemias e Blandina Noia, às minhas irmãs Fernanda e Luciana Noia, aos meus sogros Oriosvaldo e Regina Moura e aos meus cunhados.

Aos meus pacientes amigos, especialmente à Gabriella Radoll, com quem divido as principais expectativas e anseios sobre o universo da pesquisa e extensão.

Ao Otavio Lanner, pelo companheirismo e otimismo que sempre me estimulam a crescer. 
"Procurar com atenção as bases culturais de um país (sejam quais forem: pobres, miseras, populares) quando reais, não significa conservar as formas e os materiais, significa avaliar as formas criativas originais. Os materiais modernos e os modernos sistemas de produção tomarão depois o lugar dos meios primitivos, conservando, não as formas, mas a estrutura profunda daquelas possibilidades. Esta procura, realizada numa base rigorosamente científica, ridiculariza os romantismos populistas, as falsas tradições, todas as formas de enlanguescimento cultural, assim como as atitudes da tecnocracia ideológica."

Lina Bo Bardi

"Uma arquitetura sã não pode produzir-se sem o uso racional e econômico dos materiais de construção. Mesmo se falando em arquitetura enquanto arte em seu nível mais elevado. Em última análise, não ha uma diferença essencial entre o econômico e o moral. É moral aquilo que nos leva à realização final humana e para essa realização é indispensável uma utilização racional e respeitosa dos recursos naturais. Este é o sentido da palavra economia: uso cuidadoso e, portanto, profundo das possibilidades do natural, por isso esta justificada a busca das formas que se adequem de modo mais intimo às leis que regem a matéria, sempre tendo como princípio que o homem é que deve elaborar e trabalhar sobre a matéria."

Eladio Dieste

"Não conseguimos solucionar um problema permanecendo no mesmo nível de consciência em que ele foi criado."

Albert Einstein 


\section{RESUMO}

NOIA, P. R. C. Sustentabilidade socioambiental: Desenvolvimento de sistemas construtivos em bambu no Vale do Ribeira, SP. 2012. 211 f. Dissertação (Mestrado) - Faculdade de Arquitetura e Urbanismo, Universidade de São Paulo, São Paulo, 2012.

O discurso corrente sobre termos como "desenvolvimento sustentável" e "sustentabilidade" tende a ser atribuído diretamente a uma matriz de pensamento "verde" que se desenvolve de maneira independente da realidade social envolvida. No entanto, a manutenção de uma sociedade sustentável deve resgatar, sobretudo, o conceito de qualidade de vida das mesmas. Assim, configura-se a demanda de elaboração de possíveis formas de organização sustentáveis baseadas nos valores históricos, culturais e nas relações existentes entre os cidadãos e a natureza. Diante das questões levantadas, a produção da arquitetura tende a sofrer uma reflexão sobre a postura que se mostraria mais coerente com tais preceitos. A busca por uma arquitetura de baixo impacto social e ambiental pode estar ligada a uma adequada articulação entre novas tecnologias e tradições construtivas existentes, conforme o conceito de pluralismo tecnológico. Diante do cenário social e ambiental do Vale do Ribeira, SP, mostra-se necessário o pensar em culturas construtivas que garantam 0 estreitamento de relações comunitárias, o envolvimento do usuário/produtor com o processo construtivo, a formação de uma mão-de-obra capacitada e a consequente autonomia das comunidades locais. O bambu representa uma cultura agrícola de fácil manutenção no ambiente natural do Vale do Ribeira, já sendo atualmente uma das principais regiões de seu cultivo no Estado de São Paulo. Configura-se como planta com grande potencial de regeneração ambiental e de grande rendimento produtivo. Já na elaboração do material para seu uso na construção, seu processo produtivo possibilita um amplo domínio pelo usuário, configurando um importante veículo de engajamento de projetos de inclusão social, possibilitando formação, capacitação e geração de trabalho e renda. Assim, a pesquisa visa elucidar e desenvolver possíveis sistemas construtivos em bambu que respondam às questões econômicas, ambientais e sociais referentes ao universo das comunidades caiçaras e ribeirinhas do Vale do Ribeira. A pesquisa, visando questões como o desenvolvimento de um processo de construção autônomo e a valorização do sujeito-autor de seu próprio espaço, contribui para uma forma de desenvolvimento contextual com raízes legítimas, integrado a um modo de vida e a uma cultura local, que só assim poderá trazer na incursão de novas tecnologias, uma atividade social e ambientalmente sustentável.

Palavras-chave: Arquitetura Sustentável, Bambu, Culturas Construtivas, Autoconstrução, Habitação. 


\section{ABSTRACT}

NOIA, P. R. C. Socio-environmental sustainability: Development of bamboo construction systems in Ribeira's Valley, SP. 2012. 211 f. Dissertação (Mestrado) - Faculdade de Arquitetura e Urbanismo, Universidade de São Paulo, São Paulo, 2012.

The current discourse about "sustainable development" and "sustainability" is usually directly assigned to a "green" thinking, developed independently from the social reality involved. However, to maintain a sustainable society it is necessary to rescue the concept of quality of life. Thus, there is a demand of developing sustainable organizations, based on historical, cultural and on the relation between citizens and nature. Before those questions, the production of architecture tends to be an object of observation to define which position would prove more coherence with such precepts. The demand for an architecture of low social and environmental impact can be connected to a proper articulation between new technologies and existing building traditions, as the concept of technological pluralism. Given the social and environmental scenario of Ribeira's Valley, SP, it is necessary to think about constructive cultures that can guarantee a community's relations approach, the involvement of the user/producer with the construction process, the formation of a manpower and the consequent empowerment of local communities. Bamboo is an easy to maintain agricultural crop in the natural environment of Ribeira's Valley, one of the main regions of its cultivation in São Paulo State. It is a plant with great potential for environmental regeneration and high production yield. In material elaboration for construction, its production process enables a broad domain by the user, setting an important vehicle for social inclusion projects, providing education, training, employment and income generation. This research aims to elucidate and develop possibilities for bamboo construction systems that responds to economic, environmental and social issues from the caiçaras and riverside communities universe in Ribeira's Valley. The research, aimed at issues such as the development of a autonomous building process and the appreciation of the author of your own space, contributes to a contextual development with legitimate roots, integrated into local way of life and culture, which represents the only way of bringing in the incursion of new technologies, a social and environmentally sustainable.

Keywords: Sustainable Architecture, Bamboo, Constructive cultures, Self-construction, Housing. 


\section{LISTA DE ILUSTRAÇÕES}

Figura 1 - Diagrama Comunidades Sustentáveis. 19

Figura 2 - Diagrama Arquitetura de baixo impacto socioambiental.__ 19

Figura 3 - Diagrama potencial produtivo do bambu.___ 21

Figura 4 - Diagrama sobre respostas às demandas econômicas, sociais e ambientais.___ 22

Figura 5 - Foto aérea recorte de estudo - comunidades caiçaras e ribeirinhas do Vale do Ribeira. ___ 23

Figura 6 - Mapa de distribuição geográfica do bambu no Brasil.___ 25

Figura 7 - Mapa de distribuição geográfica do bambu no estado de SP: Vale do Ribeira.__ 25

Figura 8 - Infográfico comparativo entre produção de bambu e madeira.___ 26

Figuras 9 e 10 - Caiçaras consertando canoa e produção de palmito em Iguape na década de 40.___ 37

Figuras 11 e 12 - Barreado do pau-a-pique e casa de pau-a-pique no Vale do Ribeira.__ 38

Figuras 13 e 14 - Casa de madeira e cobertura em folhas de palmeiras no litoral paranaense.__ 39

Figura 15 - Plantas padrão das habitações caiçaras unifamiliares no bairro do Icapara.___ 39

Figuras 16 e 17 - Exemplos de autoconstrução recente na Barra do Ribeira. ____ 40

Figura 18 - Croquis principais arranjos de espaço encontrados na pesquisa.___ 46

Figuras 19 e 20 - Casa em madeira e casa em pau-a-pique no Jairê, Iguape. ___ 46

Figuras 21 e 22 - Interior de casa em madeira no Jairê, Iguape.__ 47

Figuras 23 e 24 - Casas em alvenaria em Icapara, Iguape.__ 47

Figuras 25 e 26 - Ilustração de caractere chinês originado do ideograma pré-histórico bambu e ilustração

Bamboo de Xu Wei, Dinastia Ming.___ 51

Figura 27 - Mapa da distribuição Geográfica do bambu no mundo.__ 52

Figura 28 - Mapa da distribuição de espécies de bambu na América.__ 53

Figuras 29 e 30 - Floresta tropical adulta e broto de bambu. __ 56

Figuras 31 e 32 - Sistemas leptomorfos e paquimorfos respectivamente._56 56

Figura 33 - Estrutura do bambu transversal e longitudinalmente. __ 58

Figura 34 - Gráfico de relação entre resistência e dureza e massa específica. ___ 59

Figuras 35 e 36 - Ensaios de compressão no Centro de Investigación de Madera y Guadua,___ 60

Universidad Nacional de Colombia.___ 60

Figura 37- Usinagem de corpos de prova para ensaios de tração no Centro de___ 60

Investigación de Madera y Guadua, Universidad Nacional de Colombia.___ 60

Figuras 38 e 39 - Propagação por pedaços de colmo e propagação por ramos laterais.___ 62

Figura 40 - Colheita de bambu.___ 63

Figuras 41 e 42 - Tratamentos de cura pela ação da fumaça e por imersão em água.___ 65

Figuras 43 e 44 - Exemplos da produção da arquitetura contemporânea oriental em bambu: Escola Em

Bangladesh (Anna Heringer e Eike Roswag) e Centro Residencial no Japão (Shoei Yoh). ___ _ 66

Figuras 45 e 46 - Habitação temporária indígena na Colômbia e habitação em bambu e madeira no Equador.

Figuras 51 e 52 - Exemplos da produção da arquitetura contemporânea brasileira em bambu: Centro

Cultural Max Feffer e Memorial dos Índios.____ 68

Figuras 53 e 54 - Floresta de Guadua na Colômbia e Guadua no projeto do Pavilhão Zeri (Simón Vélez). __ 70

Figuras 55 e 56 - Pré-fabricação de treliças para ponte (Joerg Stamn) e oficina de___ 72

pré-fabricação de peças em bambu (Marcelo Villegas). ___ 72

Figuras 57 e 58 - Fundações em tijolos e concreto isolando estruturas e vedação em bambu do solo em residência colombiana (Joerg Stamn) e no Pavilhão Zeri (Simón Vélez).___ 73

Figura 59 - Possibilidades de piso: A - Esterilla, B - Bambu em trama, C - Meia Cana e D - Cana inteira.__ 73

Figuras 60, 61, 62 e 63 - Tesoura em bambus, treliça plana em tiras de bambu___ 74

e técnicas de encaixe e corte de bambus. ___ 74 
Figura 64 - Vedações tipo 1 (de origem Peruana) e 2 (de origem Colombiana). 75

Figura 65 - Vedações tipo 3 (de origem Colombiana) e 4 (de origem Japonesa).___ 76

Figuras 66 e 67 - Casa em Bauru com parede dupla em trama de bambu revestida externamente. ___ 76 Figuras 68 e 69 - Fechamento em colmos abertos e prensados nos EUA (tipo 6) e fechamento com colmos inteiriços sobrepostos (tipo 5) no Equador (Gernot Minke).___ 76

Figuras 70 e 71 - Cobertura em telhas de bambu.___ 77 Figuras 72, 73 e 74 - Centro Residencial no Japão (Shoei Yoh) e Casa Tarumã em Botucatu (Leiko Motomura). Trama de bambu servindo como fôrma para a cura do concreto. 78

Figuras 75 e 76 - Fôrma para concreto com armação em bambu (Prof. Ghavami) e Biokreto (Prof. Beraldo).

Figuras 77 e 78 - Perfis compostos por bambu laminado.___ 80

Figura 79 - Possibilidade de nós e conexões.___ 80

Figura 80 - Conexões em junco.___ 81

Figura 81 - Conexão em boca de pescado.___ 82

Figuras 82, 83, 84 e 85 - Conexões metálicas desenvolvidas por:___ 83

Renzo Piano, Shoei Yoh, Tim Obermann e Max Mengeringhausen.___ 83

Figuras 87 e 88 - Conexão Simón Vélez e conexão em tubos moldados de tecido da UFMG.____ 85

Figuras 89, 90, 91 e 92 - Tipologias de construções tradicionais: rurais, urbanas tradicionais, ___ 90

urbanas projetadas, e urbanas marginais segundo Gutiérrez (2000).___ 90

Figuras 93, 94, 95 e 96 - Pavilhão em Xangai (Simón Vélez), pedágio em Circacia (Simón Hosie), bairro

Ciudad Alegría em Quindío (Opción Timágua) e Clube em Santiago de Cali (Carlos Vegara). ___ _ 92

Figuras 97 e 98 - Habitação de Interesse Social em Ricaurte (Simón Vélez), figuras 99 e 100 - Bairro Ciudad

Alegría em Quindío (Opción Timágua) Figuras 101 e 102 - Protótipo Habitação___ 93

de Interesse Social (Corporación Autónoma Regional del Quindío - CRQ) ___ 93

Figura 103 - Bairro El Italiano em Barcelona, Quindío.____ 95

Figura 104 - Cartilha-guia para autoconstrução - cooperação GTZ e UTP.____ 96

Figuras 105 e 106 - Habitações cooperação GTZ e UTP em construção. ___ 98

Figuras 107 e 108 - Unidades habitacionais VHC.___ 99

Figura 109 - Variações de plantas do VHC (20,5 m2, 25,6 m2 e 41m2)___ 100

Figuras 110 e 111 - Processo de montagem de painéis Viviendas Hogar de Cristo no Equador.___ 101

Figuras 112 e 113 - Unidades habitacionais-modelo PNB.__ 105

Figura 114 - Variações de plantas de PNB.___ 106

Figuras 115 e 116 - Detalhes vedação composta por painéis diafragma. ___ 107

Figuras 117 e 118 - Habitação de interesse social em Maceió. ___ 111

Figura 119 - Planta Projeto INBAMBU em Alagoas.___ 112

Figuras 120 e 121 - Processo de pré-fabricação de painéis e argamassagem do painel fixo.___ 113

Figura 122 - Diagrama metodologia de projeto de sistema construtivo em bambu. __ 118

Figuras 123 e 124 - Bambus Dendrocalamus giganteus e Bambusa tuldoides no Vale do Ribeira.___ 120

Figura 125 - Espaços modulares em sistema normalizado de madeira e guadua.__ 122

Figura 126 - Módulo simples (9m2) e união entre módulos.__ 123

Figura 127 - Ampliação da habitação pela união de módulos.__ 124

Figura 128 - Possibilidades de arranjo de habitação $54 \mathrm{m2}$. 124

Figura 129 - Tipologia de habitação de $54 \mathrm{m2}$.__ 125

Figura 130 - Possibilidades de boca de pescado. Aplicada a "de dos orejas".___ 126

Figura 131 - Painel de vedação simples tramado em Bambusa tuldoides. ___ 126

Figura 132 - Implantação do protótipo no canteiro experimental.___ 128

Figura 133 - Projeto do módulo (9 m2) da unidade habitacional.___ 128

Figuras 134, 135 e 136 - Touceira de Dendrocalamus giganteus, touceira de Bambusa tuldoides___ 132

e marcação dos colmos de Dendrocalamus giganteus maduros.___ 132 
Figuras 137 e 138 - Corte do bambu Dendrocalamus giganteus e Processo de cura sobre placa de concreto.

Figura 139 e 140 - Colmos de bambu subdivididos e transporte das peças.___ 136

Figura 141, 142, 143 e 144 - Lavagem das peças, perfuração dos entrenós, ___ 138

furo do entrenó e octoborato aplicado no tratamento.__ 138

Figura 145, 146, 147 e 148 - Imersão das peças, proteção da solução, escorrimento e secagem das peças. 140

Figura 149 - Classificação das peças pelo diâmetro. __ 141

Figuras 150, 151 e 152 - Peças pré-fabricadas em bambu,___ 142

cera de carnaúba utilizada e peça de bambu com a cera aplicada.___ 142

Figuras 153, 154, 155, 156 e 157 - Bambus em beneficiamento, corte de faca radial, retirada do parênquima, tratamento por imersão e secagem das taliscas.

Figuras 158, 159, 160, 161, 162 e 163 - Nivelamento do terreno, forma com lastro de brita, lona plástica com malha metálica, ferragem dos arranques dos pilares, concretagem e radier finalizado .__ 144

Figuras 164 e 165 - Assentamento do BTC e embasamento finalizado. ___ 145

Figuras 166, 167, 168, 169, 170, 171 e 172 - Corte para encaixe de peças, orifícios feitos por serra copo, encaixe entre peças de bambu, locação dos primeiros pórticos, grauteamento dos bambus nas esperas,

fechamento de orifícios com cola branca e serragem, braçadeiras metálicas evitando cisalhamento.___ 147

Figura 173 - Estrutura finalizada. 148

Figuras 174, 175, 176, 177, 178, 179 e 180 - Confecção dos painéis em gabarito, painel pequeno finalizado,

detalhe fixação de taliscas sem perfuração, fixação do contraventamento dos painéis, tela de viveiro, __ 149

painel grande finalizado e painéis fixados à estrutura.__ 149

Figuras 181 e 182 - Argamassagem com solo-cimento e reboco simples em cimento.__ 150

Figura 183 - Centro Cultural Max Feffer. Vista do palco.__ 172

Figura 184 - Vista lateral da cobertura.___ 174

Figura 185 - Croqui esquemático da mão francesa.___ 177

Figura 186 - Barras metálicas interligando os colmos de bambu.__ 178

Figura 187 - Montagem da cobertura - gabaritos.__ 181 


\section{LISTA DE TABELAS}

Tabela 1 - Índices do Vale do Ribeira. 41

Tabela 2 - Espécies prioritárias de bambu de acordo com o INBAR.

Tabela 3 - Propriedades do bambu, aço e concreto, valores médios.

Tabela 4 - Casos escolhidos para análise de projetos de habitação de interesse social em bambu.

Tabela 5 - Custo da habitação VHC padrão 4,80 m X 4,80 m em dólares americanos (US\$).

Tabela 6 - Fases do processo de produção do PNB.

Tabela 7 - Instrumentos para implantação de linha de produção em bambu. 


\section{LISTA DE ABREVIATURAS E SIGLAS}

\begin{tabular}{|c|c|}
\hline APO & Avaliação Pós-ocupação \\
\hline $\mathrm{BCID}$ & Banco Centro Americano de Integração Econômica \\
\hline BTC & Bloco de terra comprimida \\
\hline CCA & Cromo Cobre Arsênio \\
\hline CENA & Centro de Energia Nuclear na Agricultura \\
\hline CIBAM & Centro de Investigción de Madera y Guadua \\
\hline CONSAD & Consórcio de Segurança alimentar e Desenvolvimento Local \\
\hline CP V-ARI & Cimento Portland de Alta Resistência Inicial \\
\hline DF & Distrito Federal \\
\hline EBIOBAMBU & Escola de Bio-arquitetura e Centro de Pesquisa e Tecnologia Experimental em Bambu \\
\hline ESALQ & Escola Superior de Agricultura Luiz de Queiroz \\
\hline EUA & Estados Unidos da América \\
\hline FAU USP & Faculdade de Arquitetura e Urbanismo da Universidade de São Paulo \\
\hline FEAGRI & Faculdade de Engenharia Agrícola \\
\hline FUNBAMBU & Fundación del Bambú \\
\hline GTZ & Deutsche Gesellschaft für Technische Zusammenarbeit \\
\hline HABITAT II & Second United Nations Conference on Human Settlements \\
\hline IAC & Instituto Agronômico de Campinas \\
\hline IBGE & Instituto Brasileiro de Geografia e Estatística \\
\hline IDESC & Instituto para Desenvolvimento Sustentável e Cidadania no Vale do Ribeira \\
\hline IDHM-E & Índice de Educação \\
\hline IDHM-L & Índice de Longevidade \\
\hline IDHM-M & Índice de Desenvolvimento Humano Municipal \\
\hline IDHM-R & Índice de Renda \\
\hline INBAMBU & Instituto do Bambu \\
\hline INBAR & International Network for Bamboo and Rattan \\
\hline ISO & International Standardization Organization \\
\hline LAME & Laboratório de Modelos e Ensaios \\
\hline LCC & Laboratório de Culturas Construtivas \\
\hline MAD & Aeroporto Internacional de Madrid Barajas \\
\hline MIVAH & Ministerio de Vivienda y Asentamientos Humanos \\
\hline MDA & Ministério do Desenvolvimento Agrário \\
\hline MDS & Ministério de Desenvolvimento Social \\
\hline MG & Minas Gerais \\
\hline MMA & Ministério do Meio Ambiente \\
\hline MS & Mato Grosso do Sul \\
\hline NSR & Reglamento Colombiano de Construcción Sismo Resistente \\
\hline NTC & Norma Tecnica Colombiana \\
\hline ONU & Organização das Nações Unidas \\
\hline PNB & Proyecto Nacional del Bambú \\
\hline PNUMA & Programa das Nações Unidas para o Meio Ambiente \\
\hline PUC & Pontifícia Universidade Católica \\
\hline RJ & Rio de Janeiro \\
\hline SC & Santa Catarina \\
\hline
\end{tabular}


SP

TIBÁ

UF

UFAL

UFMG

UFPB

UFSC

UINC

UNAL

UnB

UNDP

UNESP

UNICAMP

USP

UTP

$\mathrm{VHC}$

WWF

ZERI
São Paulo

Tecnologia Intuitiva e Bio-arquitetura

Unidade da Federação

Universidade Federal de Alagoas

Universidade Federal de Minas Gerais

Universidade Federal da Paraíba

Universidade Federal de Santa Catarina

International Union for Conservation of Nature

Universidad Nacional de Colombia

Universidade de Brasília

United Nations Development Programme

Universidade Estadual Paulista Júlio de Mesquita Filho

Universidade Estadual de Campinas

Universidade de São Paulo

Universidad Tecnologica de Pereira

Viviendas Hogar de Cristo

World Wide Fund for Nature

Zero Emissions Research Initiative 
SUMÁRIO

DEDICATORIA

AGRADECIMENTOS

RESUMO

ABSTRACT

8

LISTA DE ILUSTRAÇÕES 9

LISTA DE TABELAS 12

LISTA DE ABREVIATURAS E SIGLAS 13

SUMARIO 15

CAPITULO 1 - INTRODUÇÃO 17

1.1 - ColocaÇÃo do PROBLEMA E JUSTIFICATIVA 18

1.2 - RECORTE DO TRABALHO 22

1.3 - OBJETO DE ESTUDO 26

1.4 - OBJETIVOS DA DISSERTAÇÃO 27

1.5 - PROCEDIMENTOS METOdOLOGICOS

CAPITULO 2 - EMBASAMENTO TEORICO 29

2.1 - SUSTENTABilidAde: Conceitos E Definiıç̃̃es 30

2.1.1 - SUSTENTABILIDADE E DESENVOLVIMENTO SUSTENTAVEL

2.1.2 - DesenVolvimento, Progresso e Meio Ambiente

2.1.3 - DESENVOLVIMENTO SUSTENTAVEL E ECODESENVOLVIMENTO

2.1.4 - COMUNIDADES SUSTENTAVEIS E ETNOCONSERVAÇÃO

2.1.5 - ARQUITETURA DE BAIXO IMPACTO SOCIOAMBIENTAL

2.2 - O RECORTE EM QUESTÃO: VALE DO RIBEIRA

2.2.1 - HISTORIA E MEMORIA 35

2.2.2 - CULTURAS CONSTRUTIVAS 36

2.2.3 - QUESTÕES CONTEMPORANEAS 40

2.2.4 - DesenVolvimENTO SUSTENTAVEL No VALE Do RibeiRA 41

2.2.5 - PESQUISA DE CAMPO

3.1 - O BAMBU COMO FONTE DE MATERIA-PRIMA PARA A CONSTRUÇÃO CIVIL. 50

3.1.1 - INTRODUÇÃO 50

3.1.2 - A CULTURA DO BAMBU NO MUNDO

51 
3.1.3 - CARACTERISTICAS GERAIS

3.1.4 - O BAMBU E A CONSTRUÇÃO CIVIL 66

3.1.5 - COMPONENTES CONSTRUTIVOS EM BAMBU $\quad 71$

3.1.6 - NORMATIZAÇÃO

3.1.7 - PRE-FABRICAÇÃO DE HABITAÇÃO

3.2. Sistemas CONSTRUTIVOS EM BAMBU: O CASO COLOMBIANO E PROJETOS DE HABITAÇÃo DE INTERESSE SOCIAL.

3.2.1 - ARQUITETURA TRADICIONAL COLOMBIANA 87

3.2.2 - PROJETOS DE HABITAÇÃo de INTERESSE SOCIAL EM BAMBU: REFERENCIAS DE PROCESSOS PRODUtIVOS 92

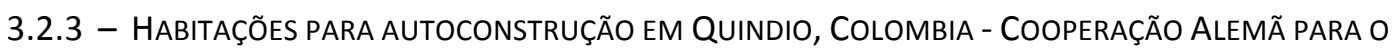

DESENVOLVIMENTO (GTZ).

3.2.4 - HABITAÇÕES DE INTERESSE SOCIAL EM GUAYAQUIL, EQUADOR - VIVIENDAS HOGAR DE CRISTO. 99

3.2.5 - HabitaÇões Projeto Nacional de Bambu na Costa Rica 104

3.2.6 - HABITAÇõES DE INTERESSE SOCIAL EM ALAGOAS, BRASIL - INSTITUTO dO BAMBU. 110

CAPITULO 4 - PROTOTIPO DE SIMULAÇÃO CONSTRUTIVA 116

4.1 - Sistemas CONSTRUtIVOS EM BAMBU : PosSIBILIDADES DE DESENVOLVIMENTO No VALE DO RIBEIRA 117

4.1.1 - PREMISSAS PARA ELABORAÇÃO DO PROJETO

$\begin{array}{ll}\text { 4.1.2 - PROJETO } & 122\end{array}$

4.2 - ENSAIOS DE VIABILIDADE DE EXECUÇÃO

4.2.1 - PROCEDIMENTOS DE ELABORAÇÃO DO PROTOTIPO.

$\begin{array}{ll}4.3-R E S U L T A D O S & 150\end{array}$

4.3.1 - RESULTADO POR ETAPAS DO PROCESSO 150

$\begin{array}{ll}4.3 .2-\text { CONCLUSÕES } & 153\end{array}$

CAPITULO 5 - CONSIDERAÇÕES FINAIS

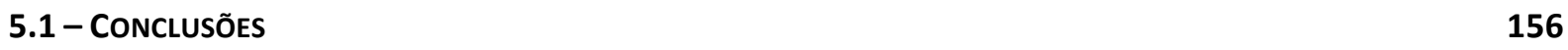

$\begin{array}{ll}5.3 \text { - PERSPECTIVA PARA PESQUISAS FUTURAS } & 159\end{array}$

$\begin{array}{lr}\text { BIBLIOGRAFIA } & 160\end{array}$

APENDICE - QUESTIONARIOS LEVANTAMENTO DE DADOS PRIMARIOS $\quad 168$

\begin{tabular}{ll} 
APENDICE - ENTREVISTAS & 171 \\
\hline
\end{tabular} 
CAPÍTULO 1 - INTRODUÇÃO 


\section{1 - Colocação do problema e justificativa}

O discurso corrente sobre termos como "desenvolvimento sustentável" e "sustentabilidade" tende a ser atribuído diretamente a uma matriz de pensamento "verde" que se desenvolve de maneira independente em relação à realidade social envolvida. 0 conceito, fundamentalmente político, carece de uma abordagem mais ampla, engajada em ações ambientais conscientes, mas sem desprezar as causas sociais e econômicas envolvidas em tais situações (DIEGUES, 1992).

Percebe-se a necessidade de reflexão acerca de algumas questões sobre crescimento econômico, distribuição de renda, conservação de recursos naturais que conduzem a um questionamento maior, a uma reformulação da própria conceituação de desenvolvimento. É necessário o resgate de um conceito de desenvolvimento sustentável ligado ao bem-estar coletivo, mesmo que isso represente uma utopia de repensar a noção de desenvolvimento vigente em nossa sociedade (LAYRARGUES, 1998).

A manutenção de uma sociedade sustentável deve resgatar, sobretudo, o conceito de qualidade de vida. Assim, configura-se a demanda de elaboração de possíveis formas de organização sustentáveis baseadas nos valores históricos, culturais e nas relações existentes entre os cidadãos e a natureza, conforme Figura 1. A implantação do conceito de comunidades sustentáveis traz consigo consequências positivas para a prática da sustentabilidade, como a manutenção dos processos ecológicos fundamentais e a preservação das diversidades genéticas e biológicas. O conhecimento acumulado pelas comunidades tradicionais permite o manuseio, a classificação, a domesticação da biodiversidade respeitando os limites do crescimento. Todo o saber-fazer dessas comunidades é desenvolvido e repassado oralmente geração após geração, e configura uma forma alternativa à ciência moderna para a compreensão e manutenção do meio ambiente (DIEGUES, 2002).

Diante das questões levantadas, a produção da arquitetura, assim como tantas outras práticas envolvidas, tende a sofrer uma reflexão sobre a postura que se mostraria mais coerente com tais preceitos. A concepção do espaço está diretamente relacionada à construção, à utilização de recursos materiais e aos processos para transformá-los, por menos elaborados que estes sejam. A busca por uma arquitetura de baixo impacto social e ambiental pode estar ligada a uma adequada articulação entre novas tecnologias e tradições construtivas existentes, conforme o conceito de pluralismo tecnológico (Figura 2). 


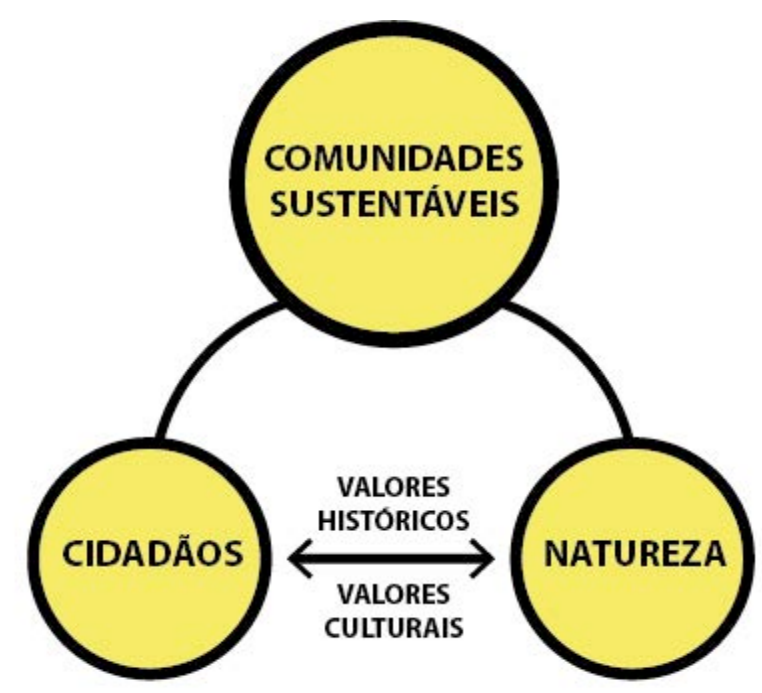

Figura 1 - Diagrama Comunidades Sustentáveis.

Fonte: Autoria própria.
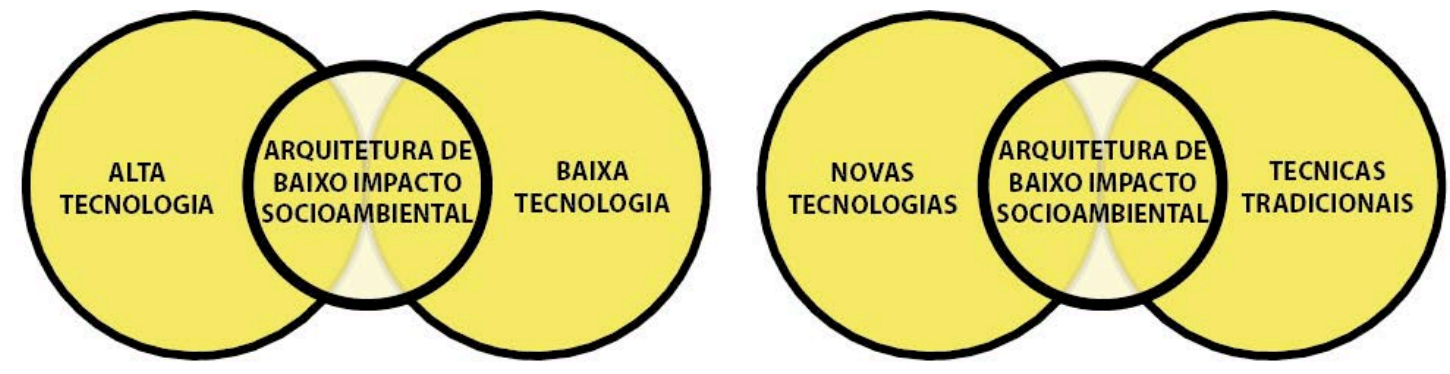

Figura 2 - Diagrama Arquitetura de baixo impacto socioambiental.

Fonte: Autoria própria.

Considerando o recorte da pesquisa em questão, há nessa nova concepção de arquitetura a expectativa de assimilar a evolução tecnológica da construção civil sem esquecer a arquitetura tradicional que valoriza o saber popular e seu espírito construtivo funcional. Há um delicado exercício de recuperação desse saber coletivo e de suas técnicas históricas. Assim, uma arquitetura de baixo impacto social e ambiental configura-se como uma resposta ao meio no qual se insere. Esse caráter contextual faz com que características geográficas, econômicas, sociais, culturais, de território e de recursos disponíveis sejam fatores determinantes da arquitetura a ser produzida (WEIMER, 2005).

No caso do Baixo Vale do Ribeira, a região ainda conta com significativos recursos naturais preservados e um singular patrimônio cultural. Em seu território, encontram-se comunidades remanescentes quilombolas, indígenas, caiçaras e de pequenos produtores 
rurais. Toda essa riqueza socioambiental, no entanto, contrapõe-se aos mais baixos índices sociais do Estado de São Paulo, comparáveis aos da região nordeste do país. Os fatores determinantes para essa conformação atual vão desde o isolamento territorial, passando pela carência de infraestrutura econômica e pela fragilidade das relações comunitárias.

A cultura construtiva desse coletivo sempre esteve intimamente ligada ao meio no qual está inserida, na eleição de materiais, processos, sistemas e organizações sociais que irão resultar no espaço construído escolhido para acolher os valores estabelecidos pela comunidade. A integração do caiçara com o ambiente é tamanha que o habitante faz-se o artífice de seu meio, sendo hábil a executar as mais diversas atividades artesanais, manuais, ou especializadas. Quanto às construções habitacionais, estas trazem consigo um aspecto de simplicidade na medida em que são compostas por materiais encontrados no meio, sempre indicando uma vinculação com a natureza em virtude das limitações econômicas e sociais às quais está sujeita (VALENTIN, 2005).

A partir dos anos 1960, com grandes transformações do ponto de vista territorial, as comunidades sofreram violento processo de expulsão de seu território, ora pela ocupação de veranistas, ora pela instalação de áreas de proteção. A crise gerada nas periferias das grandes cidades pela explosão da especulação imobiliária deu início a um processo de favelização da comunidade caiçara, no qual as novas construções acabaram perdendo muitas das características da construção regional, transformando-se em construções desintegradas, descaracterizadas. Pode-se traçar um paralelo entre a realidade atual das construções e a instrumentalização do caiçara. Estes artífices do meio perderam ao longo do processo o domínio sobre o fazer, tornando-se mão-de-obra desqualificada para lidar com os novos materiais e sistemas construtivos industrializados que agora se encontram ao alcance (DIEGUES, 2005).

Diante do cenário social e ambiental da região, mostra-se necessário o pensar em culturas construtivas que garantam o estreitamento de relações comunitárias, o envolvimento do usuário/produtor com o processo construtivo, a formação de uma mão-deobra capacitada e a consequente autonomia das comunidades do Vale do Ribeira. A pesquisa inicial por tais processos construtivos, embasada em questões ambientais, sociais e culturais fundamentais no universo em questão apontou o uso do bambu como uma possibilidade de matéria-prima que representa enquanto tecnologia, uma prática social e ambientalmente sustentável.

De acordo com o diagrama presente na Figura 3, o bambu representa uma cultura agrícola de fácil manutenção no ambiente natural do Vale do Ribeira, sendo já atualmente uma das principais regiões de seu cultivo no Estado de São Paulo. Configura-se como planta com grande potencial de regeneração ambiental e de grande rendimento produtivo. Já na 
elaboração do material para seu uso na construção, seu processo produtivo possibilita um amplo domínio pelo usuário. Analogamente à tradicional cultura construtiva da madeira, as etapas de produção de bambu para construção civil são todas passíveis de engajamento do usuário, desde o cultivo enquanto espécie vegetal até a construção propriamente dita. Desta forma, tal cultura construtiva representa um notável veiculo de engajamento de projetos de inclusão social, possibilitando formação, capacitação e geração de trabalho e renda. Além disso, a geração de uma fonte de renda poderia ser uma das bases da integração econômica de tais comunidades.

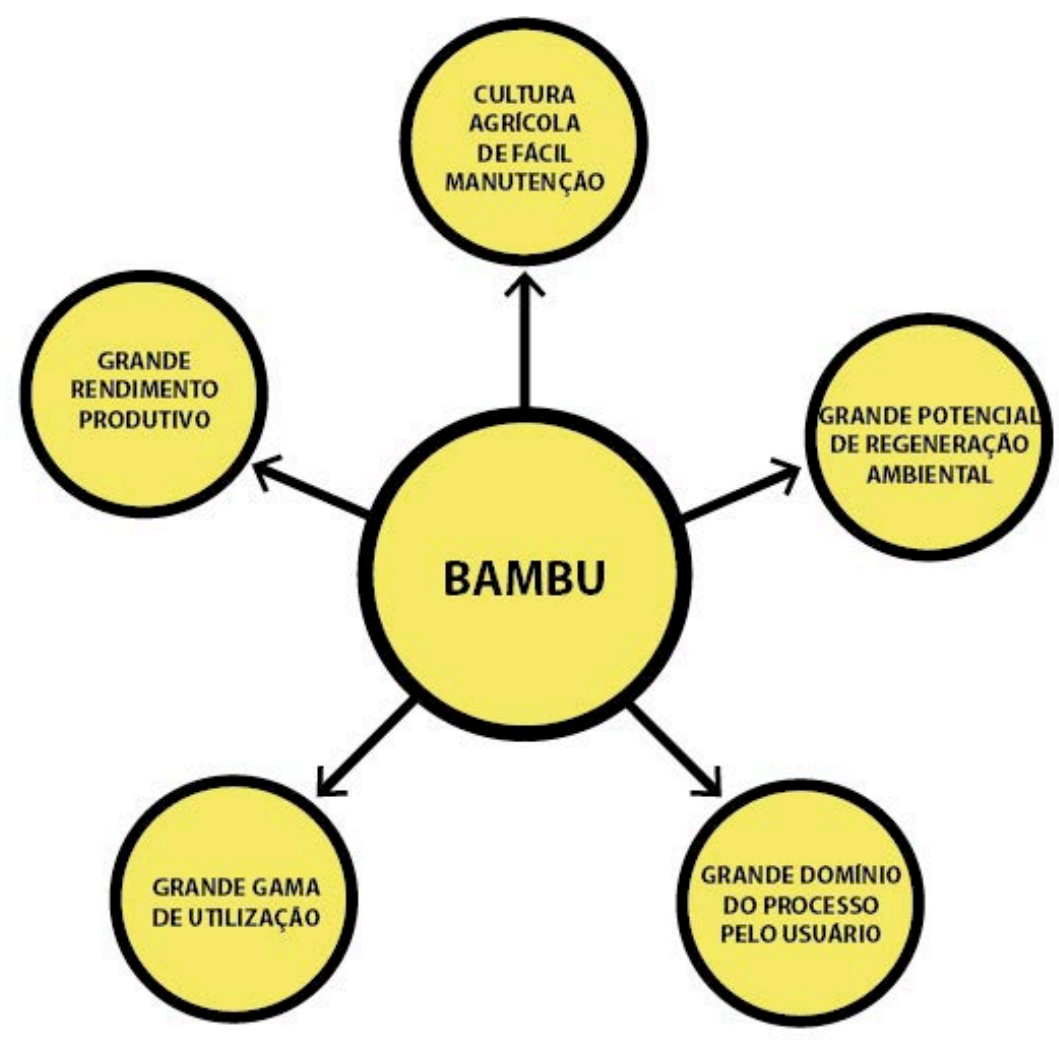

Figura 3 - Diagrama potencial produtivo do bambu.

Fonte: Autoria própria.

Assim, a pesquisa visa elucidar e desenvolver possíveis sistemas construtivos em bambu que respondam às questões econômicas, ambientais e sociais referentes ao universo das comunidades caiçaras e ribeirinhas do Vale do Ribeira. A pesquisa, visando questões como o desenvolvimento de um processo de construção autônomo e a valorização do sujeito-autor de seu próprio espaço, contribui para uma forma de desenvolvimento contextual com raízes legítimas, integrado a um modo de vida e a uma cultura local, que só assim poderá trazer na incursão de novas tecnologias, uma atividade social e ambientalmente sustentável. 


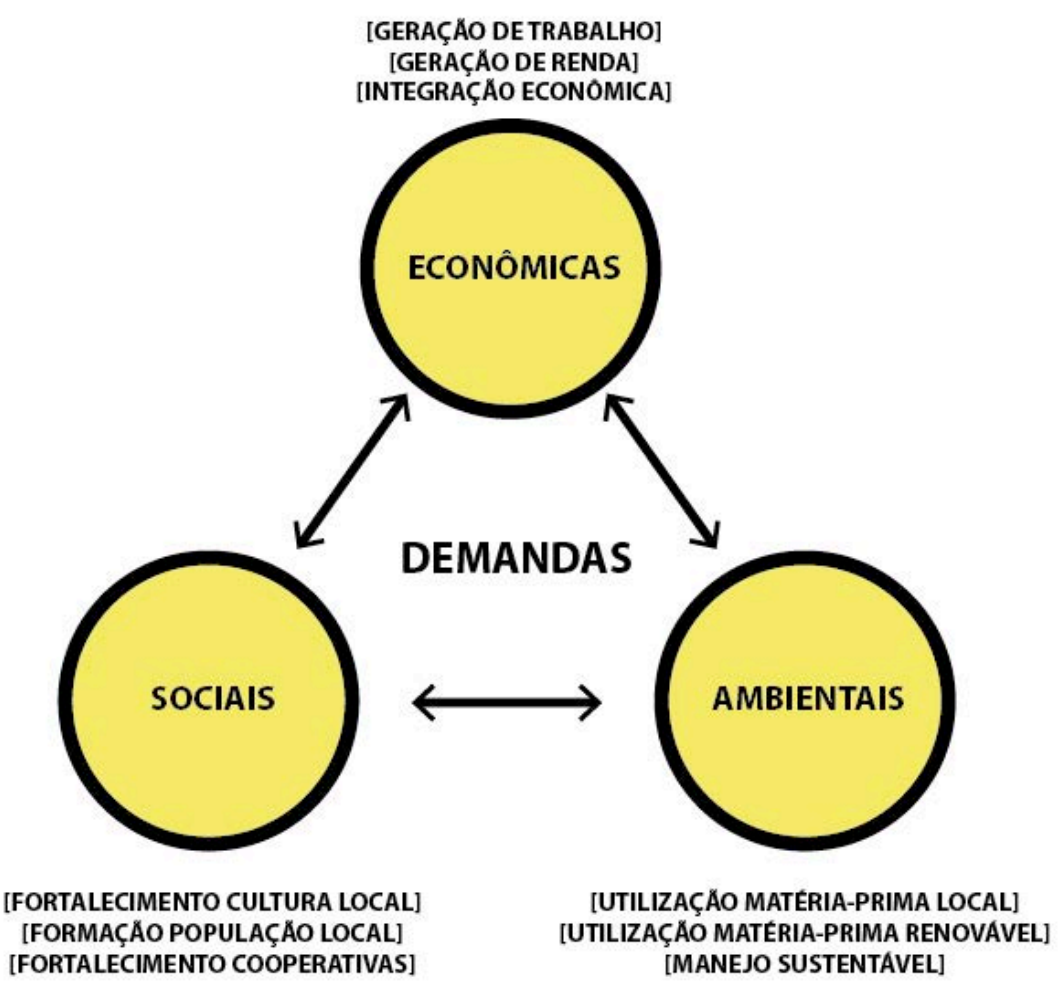

Figura 4 - Diagrama sobre respostas às demandas econômicas, sociais e ambientais.

Fonte: Autoria própria.

\section{2 - Recorte do trabalho}

Para uma melhor delimitação da área estudada foi recortada uma região de estudo inserida na região do Vale do Ribeira, conforme Figura 5. O Vale configura uma região com enorme variedade de situações físicas, geográficas e culturais. Em seu território existem comunidades remanescentes quilombolas, indígenas, caiçaras e de pequenos produtores rurais. Assim, o estudo será desenvolvido abordando as características de pluralidade do Vale do Ribeira, mas focando nas tradicionais comunidades caiçaras e ribeirinhas litorâneas do baixo Ribeira, como Icapara, Pontal, Barra do Ribeira e Iguape.

Quanto ao sistema construtivo a ser desenvolvido, os objetivos principais do sistema são:

- a economia de recursos materiais

- a cultura e memória construtiva

- a inovação tecnológica 
- o desenvolvimento local e durável

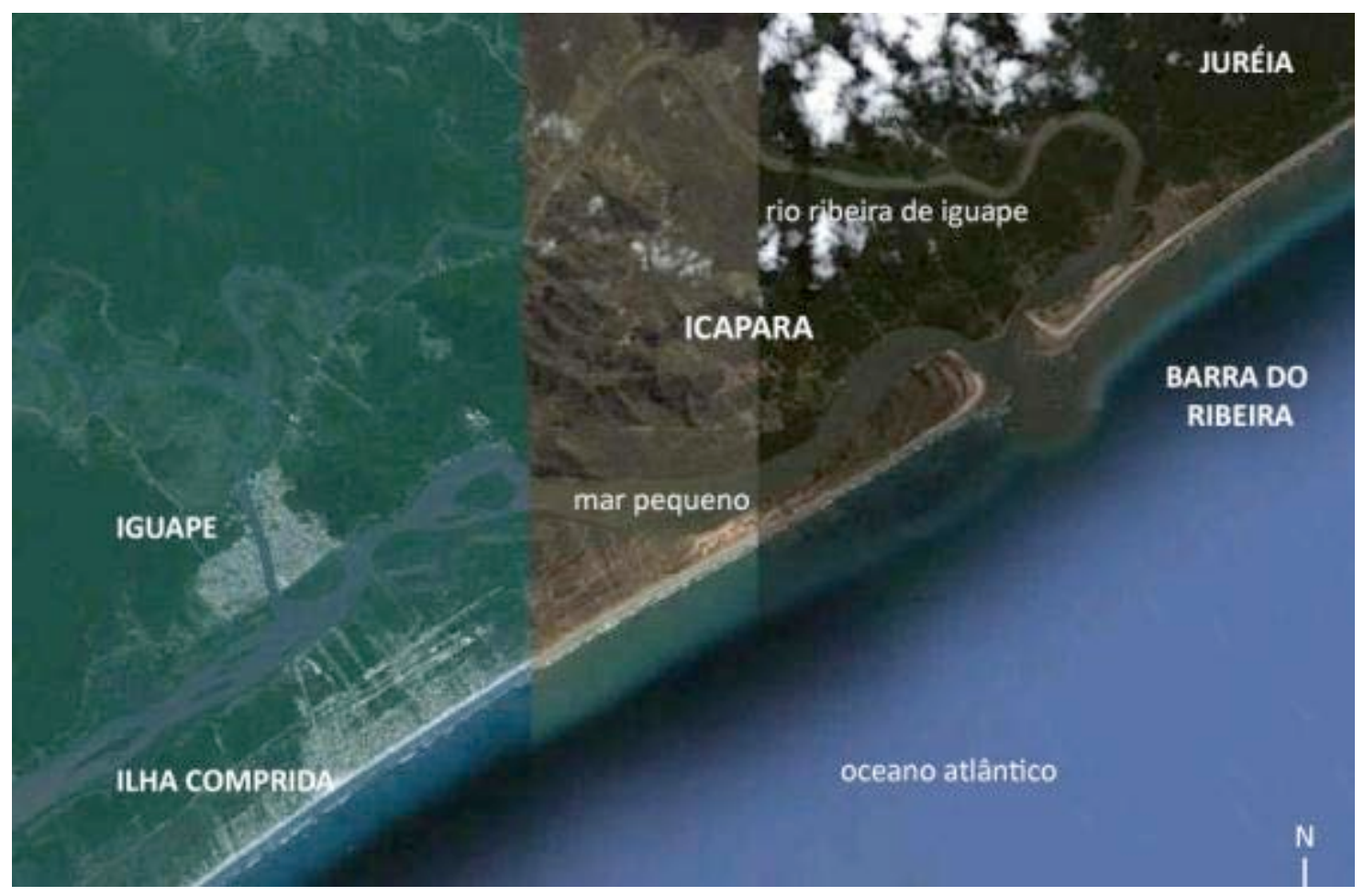

Figura 5 - Foto aérea recorte de estudo - comunidades caiçaras e ribeirinhas do Vale do Ribeira.

Fonte: Google Earth (adaptado).

O contexto existente no recorte de trabalho escolhido indica duas questões como pontos de partida para o raciocínio sobre as principais demandas do sistema construtivo a ser desenvolvido: o isolamento territorial e as novas políticas de conservação ambiental.

Segundo Silva (2005), os primeiros autores que elaboraram alguma literatura sobre a região ${ }^{1}$ afirmavam desde então que a posição de isolamento geográfico que a região em questão tinha com o planalto, a fez e sempre a fará estar à parte do dinamismo econômico lá existente, criando-se assim as bases para interpretação de que tais comunidades caiçaras se constituíram "comunidades isoladas", permanecendo relativamente imunes ao desenvolvimento capitalista. De fato, tal isolamento territorial é perceptível no local, mesmo atualmente, tendo sido relativizadas as distâncias físicas.

\footnotetext{
${ }^{1}$ Memorialistas locais como Ernesto Guilherme Young e Antônio Paulínio de Almeida iniciaram na década de 1940 registros historiográficos sobre o Vale do Ribeira.
} 
Assim, o fator do isolamento geográfico e fragilidade de articulação física configura um desenvolvimento local vinculado à autonomia regional. O sistema deve ser concebido atentando portanto:

- à autonomia produtiva - domínio dos processos produtivos pelo habitante/produtor/usuário,

- à autonomia na provisão de matéria-prima - produção local de matéria prima.

Quanto à produção de matéria-prima local, a forte relação histórica do habitante caiçara com a natureza enquanto meio de onde extrai seu sustento faz com que esta possa ser uma prática compatível com sua realidade cultural.

A segunda questão, referente às novas políticas de conservação ambiental, configura um afastamento do caiçara, habitante local, de seu meio natural. Apesar de representar relativo controle à devastação da especulação imobiliária e às práticas exploratórias ilegais, as políticas ambientais que instauraram uma série de unidades de conservação a partir da década de 1970 acarretaram uma ameaça ao direito civil de tais comunidades, que, impedidas de realizar as atividades tradicionais caiçaras, sofreram grandes mudanças em sua cultura material e imaterial.

Essas e outras questões serão desenvolvidas ao longo da dissertação; no entanto, foram importantes para a definição do material que possivelmente representará uma alternativa à tais demandas apresentadas na elaboração do sistema construtivo. Ao longo do desenvolvimento dessas questões, a fonte natural de matéria-prima para a construção provinda da cultura do bambu introduziu-se como uma boa alternativa de uso para a elaboração de um sistema construtivo por diversos argumentos (Figuras 6 e 7).

Enquanto cultura agrícola a ser inserida na região, o bambu possui significativas vantagens. Trata-se de uma planta perene e altamente renovável, sem necessidade de replantio (Figura 8). É uma planta tropical muito bem adaptada às condições climáticas locais, já sendo atualmente produzida ao longo do Vale do Ribeira.

No âmbito da preservação ambiental, sua produção além de aliviar a pressão para a exploração de madeiras pertencentes a ecossistemas ameaçados no Brasil representa importante expressão na regeneração e proteção ambiental, reflorestando e recompondo matas ciliares, contendo solos e evitando erosões. Segundo Pereira e Beraldo (2008), o bambu é um material renovável e de baixo custo de produção, além de possuir baixo tempo de renovação e grande rendimento anual por unidade de área. 


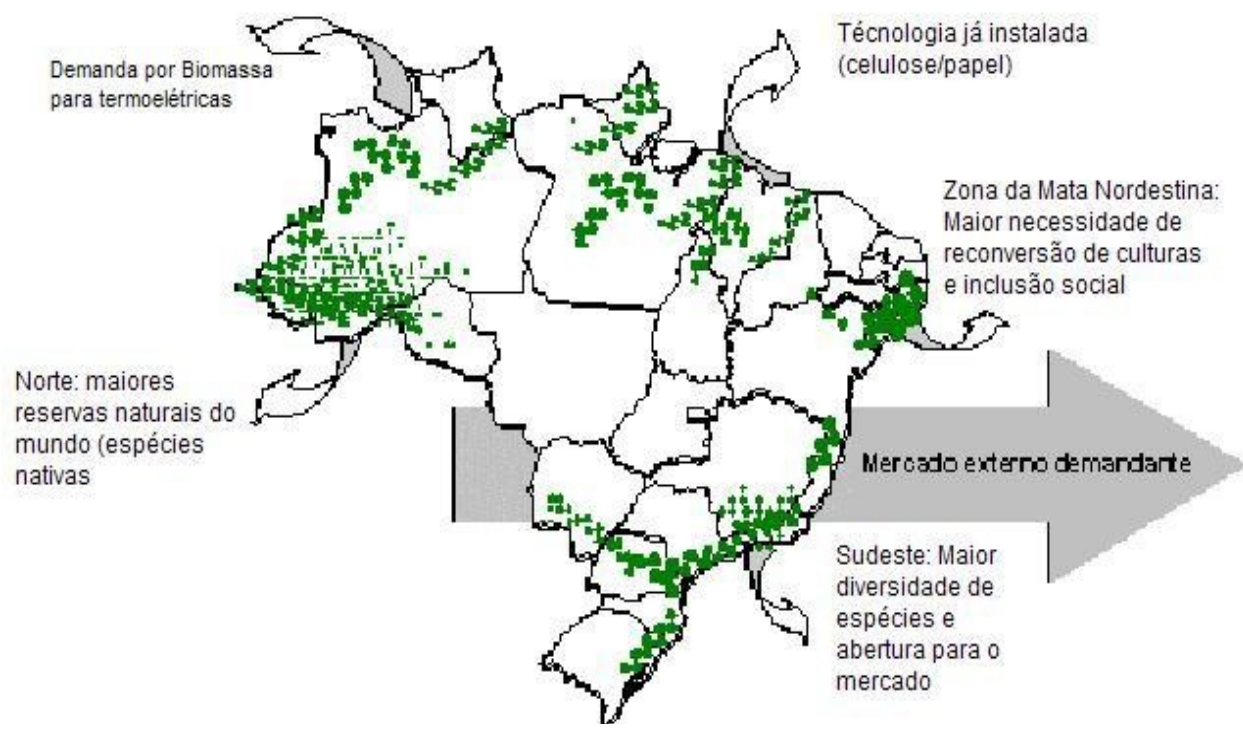

Figura 6 - Mapa de distribuição geográfica do bambu no Brasil.

Fonte: Bambu Carbono Zero.

Distribuição Geográfica de área cultivada e número de produtores, 2007/2008

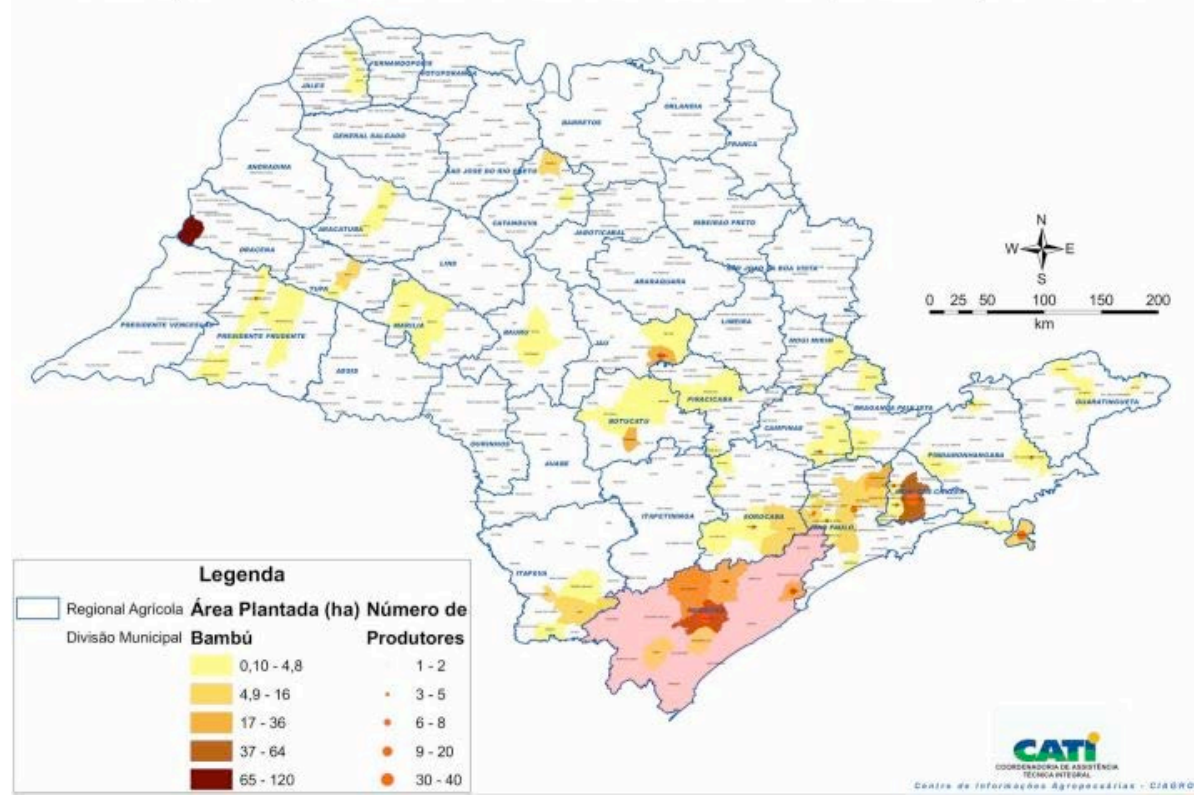

Figura 7-Mapa de distribuição geográfica do bambu no estado de SP: Vale do Ribeira.

Fonte: http://www.cati.sp.gov.br/projetolupa/ 


\section{BAMBOO CONSERVATION - THE \$EN\$ IBLE WAY}

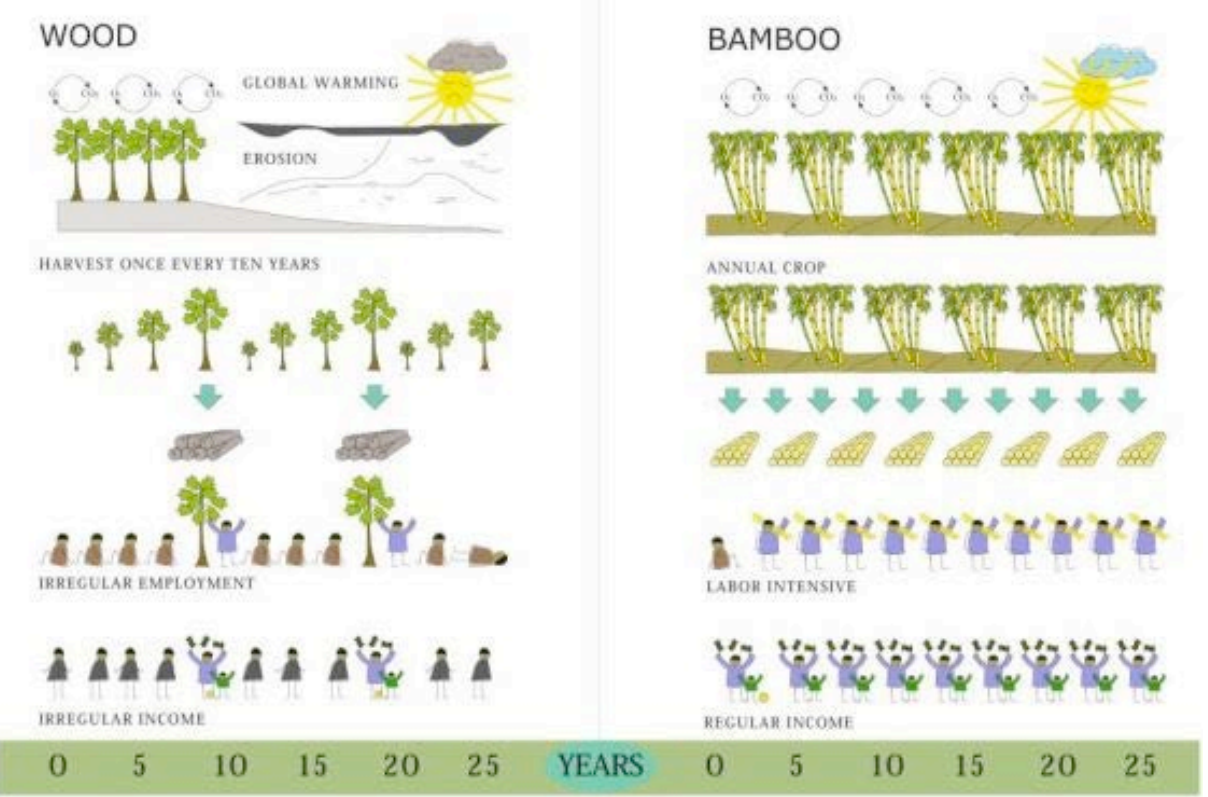

Figura 8 - Infográfico comparativo entre produção de bambu e madeira.

Fonte: http://www.bamboocentral.org

Enquanto material, o bambu possibilita ao usuário um fácil domínio de todo seu processo produtivo. Todas as suas etapas são passíveis de execução pelo usuário de maneira relativamente simples, desde o cultivo, o tratamento até o manuseio, sendo assim visto como uma matéria-prima já consolidada no engajamento de projetos de inclusão social e qualificação da mão de obra. Por fim, tal cultura construtiva pode vir a representar um importante meio de formação social, inserindo e qualificando tal população que, conforme já mencionado, desintegrou muito do saber fazer correspondente ao modo de vida que possuíram.

\section{3 - Objeto de estudo}

O objeto de estudo da pesquisa é composto por duas partes:

- As comunidades caiçaras e ribeirinhas e ribeirinhas do Vale do Ribeira - enfoque histórico em suas culturas construtivas.

- Bambu como fonte de matéria-prima para construção civil - enfoque em sistemas construtivos. 
Apesar da aparente divisão em dois objetos de estudo, as partes são diretamente relacionadas e representam complementaridade no todo da pesquisa.

\section{4 - Objetivos da dissertação}

A pesquisa possui como objetivo geral o desenvolvimento de sistemas construtivos em bambu baseados no contexto das comunidades caiçaras e ribeirinhas do Vale do Ribeira que visem uma atividade socialmente e ambientalmente sustentável.

Dentre os objetivos específicos, a pesquisa busca:

- analisar o conceito de sustentabilidade e desenvolvimento sustentável no contexto das comunidades caiçaras e ribeirinhas do Vale do Ribeira;

- analisar o bambu como matéria-prima para a construção civil e suas aplicações;

- analisar, por meio da elaboração de sistemas construtivos em bambu, as possibilidades de emprego do bambu para a construção civil;

- analisar as possibilidades de formação da mão-de-obra;

- analisar as possibilidade de geração de trabalho e renda;

- desenvolver alternativas de sistemas construtivos com o material.

\section{5 - Procedimentos metodológicos}

O trabalho utiliza-se do método empírico e qualitativo dividido em três partes:

- 1a parte - Embasamento teórico: Desenvolvimento sustentável e sustentabilidade socioambiental nas comunidades caiçaras e ribeirinhas do Vale do Ribeira: Compreende a etapa de revisão bibliográfica e levantamento do estado da arte do aspecto construtivo contextual do Vale do Ribeira. Elaborada a partir de fontes primárias como a literatura do estado da arte sobre o local e em fontes secundárias como pesquisa de campo, com registro fotográfico e a realização de entrevistas com moradores na área de estudo. 
- 2a parte - Base empírica: 0 bambu como fonte de matéria-prima para o desenvolvimento de sistemas construtivos sustentáveis para a região em questão: Compreende a etapa de desenvolvimento dos materiais analisados no embasamento teórico e revisão bibliográfica sobre o material bambu. São analisados processos produtivos do bambu para a construção civil, sistemas construtivos existentes, sistemas vinculados às demandas locais e estudos de casos de habitações de interesse social relacionados ao contexto. Também são realizadas entrevistas com profissionais especialistas sobre o tema do bambu na arquitetura e construção.

- 3a parte - Protótipo de simulação construtiva:

Desenvolvimento de hipótese (projeto de sistema construtivo) baseada em:

1. Contexto específico: contexto social e técnico das comunidades caiçaras e ribeirinhas do Vale do Ribeira analisado na 1a parte;

2. Estudo de caso: os casos de projetos de habitação de interesse social analisados na 2a parte;

3. Normas de construção: normas colombianas de construção em guadua: NTC 5300 "Cosecha y Poscosecha de los culmos de Guadua angustifolia Kunth", NTC 5301 "Secado e inmunizado de los culmos de Guadua angustifolia Kunth" e NTC 5407 "Uniones de estructuras con Guadua angustifolia Kunth".

O desenvolvimento do sistema construtivo também baseou-se na norma da International Standards Organization ISO N31352 ${ }^{3}$ como outro critério metodológico para o desenvolvimento de hipóteses de projeto. O método empregado para o projeto do sistema construtivo possuiu uma abordagem sistêmica, baseada em definições que determinam os fatores que fazem parte desse sistema e uma constante realimentação de informações no processo de pesquisa.

Após o desenvolvimento de hipótese de sistema construtivo foi realizado um protótipo de simulação construtiva como método experimental, cujo objetivo foi a verificação da viabilidade de execução física dos sistemas estudados e o real desempenho das técnicas construtivas elaboradas.

\footnotetext{
${ }^{3}$ INTERNATIONAL STANDARDIZATION ORGANIZATION - ISO N313 (Bamboo Structural Design)
} 
CAPÍTULO 2 - EMBASAMENTO TEÓRICO 


\section{1 - Sustentabilidade: Conceitos e Definições}

\subsection{1 - Sustentabilidade e Desenvolvimento Sustentável}

Por se tratar de um conceito fundamentalmente político, a discussão sobre o termo "desenvolvimento sustentável" pode ter atribuições das mais variadas linhas de pensamento. Em geral há uma tendência de alguns setores ambientalistas em atrelar o conceito a um discurso "verde" cuja matriz de pensamento desenvolve-se de maneira independente à realidade social envolvida. A manutenção de uma ordem econômica atual gera uma grande deficiência nas discussões gerais sobre o tema, que normalmente se atém apenas aos rumos do desenvolvimento vigente para uma prática econômica mais engajada com ações ambientais conscientes, sem analisar, sob uma ótica mais ampla, as causas sociais e econômicas que desencadeiam tal situação ambientalmente desfavorável.

A partir dos anos 1970, uma série de documentos ${ }^{4}$ foi produzida sobre o conceito, entre eles o mais conhecido é o "Nosso Futuro Comum" (1988), da Comissão Brundtland (ONU, 1988). O informe definiu o conceito de desenvolvimento sustentável como "o desenvolvimento que satisfaz as necessidades presentes, sem comprometer a capacidade das gerações futuras de suprir suas próprias necessidades". Um dos pontos favoráveis do documento é que este aproxima o importante caráter político e social nas relações entre os países na elaboração de uma consciência global sobre o assunto. "Ao menos em teoria, introduz uma dimensão ética e política, ausente em algumas propostas anteriores: o desenvolvimento é um processo de mudança social, que implica transformações das relações econômicas e sociais" (DIEGUES, 2002).

Dessa forma, a proposta põe em questão alguns pontos sobre crescimento econômico, distribuição de renda, conservação de recursos naturais que levam a um questionamento maior, a uma necessidade de reformulação da própria conceituação de desenvolvimento vigente. Assim, é necessário o resgate de um conceito de desenvolvimento sustentável ligado ao bem-estar da sociedade, mesmo que isso represente uma utopia de repensar a noção de desenvolvimento da nossa sociedade.

\footnotetext{
${ }^{4}$ Documentos como a Estratégia Mundial para a Conservação (1980), o informe Nosso Futuro Comum (1987), da Comissão Brundtland (ONU, 1988), Cuidar de Terra (UINC, WWF e PNUMA, 1991) e o informe da Comissão de Desenvolvimento e Meio Ambiente da América Latina e Caribe (1991) foram importantes instrumentos para a discussão dos conceitos de desenvolvimento sustentável.
} 


\subsection{2 - Desenvolvimento, Progresso e Meio Ambiente}

O modelo clássico de desenvolvimento estabelecido na ordem econômica em vigor significa o progresso da sociedade para níveis de acumulação de capital cada vez maiores. Nessa visão, a quantidade de riqueza material de uma sociedade representa o potencial produtivo da mesma (DIEGUES, 1992).

Assim, o conceito de progresso atrelado a tal raciocínio implica em uma evolução baseada no desenvolvimento de conhecimentos técnico-científicos, no qual o homem, com pleno domínio sobre o saber técnico, é capaz de controlar a natureza e dela extrair tudo para sua serventia. Desenvolvimento passou a significar crescimento econômico que por sua vez passou a significar industrialização. $O$ ideal de bem-estar dos países desenvolvidos estava diretamente ligado ao processo de industrialização, como uma mandatória trajetória linear a ser percorrida por todos os países que o almejassem. Nesse contexto, a então chamada ecologia seria uma desvantagem na corrida pelo desenvolvimento pois representaria uma redução no crescimento econômico. No caso dos países em desenvolvimento, a ainda farta natureza, representando uma estática provedora de recursos para o crescimento econômico, ao ter seu ritmo de exploração diminuído estaria freando a promissora caminhada desenvolvimentista (LAYRARGUES, 1998).

A reflexão mundial acerca de novos modelos de desenvolvimento culminou com as crises de petróleo da década de 1970. Sucedendo um período de grande prosperidade econômica para as potências mundiais ${ }^{5}$, tais crises representaram um alerta para uma questão que cabe a todo o mundo. Começa a surgir o desafio de elaboração de um ideal de sociedade desenvolvida de maneira equilibrada e diversa, com opções econômicas e tecnológicas diferenciadas, voltadas principalmente para o "desenvolvimento harmonioso das pessoas" e de suas relações com o conjunto do mundo natural.

“(...) ganha sentido a ideia de que não existe um único paradigma de sociedade do bem-estar (a ocidental) a ser atingido por vias do "desenvolvimento" e do "progresso" linear. Há necessidade de se pensar vários tipos de sociedades sustentáveis, ancoradas em modos particulares, históricos e culturais de relações com os vários ecossistemas existentes na biosfera e dos seres humanos entre si." (DIEGUES, 1992, p.40).

Começa-se a pensar o desenvolvimento sustentável a partir de um processo de mudança social estrutural, significando transformações nas próprias relações materiais e sociais já estabelecidas. Tanto em escala nacional quanto em escala global, é necessário que esse desenvolvimento atenda aos anseios de conservação dos recursos naturais, mas que

\footnotetext{
${ }^{5}$ O período de pós-guerra, representado pelo consumo de massa, pelo uso de fontes energéticas de baixo custo e pela instalação de multinacionais ao redor do mundo, trouxe grande favorecimento aos Estados Unidos, Europa e Japão. Tal processo desencadearia uma estratégia de dominação ideológica, econômica e política de tais potências sobre outras formas de organização não capitalistas existentes no mundo (DIEGUES, 1992).
} 
também garanta a democratização do acesso a esse recurso bem como o acesso aos benefícios provenientes dos mesmos.

\subsection{3 - Desenvolvimento Sustentável e Ecodesenvolvimento}

Diante da importante discussão acerca da degradação ambiental e da extinção de recursos materiais desencadeada, alguns modelos de desenvolvimento surgiram a partir da década de 1970, entre eles, o Ecodesenvolvimento. Embora não seja tão difundido quanto o conceito de Desenvolvimento Sustentável, o conceito de Ecodesenvolvimento apresenta uma inspirável definição que pode ser aproximada de uma maneira interessante ao universo de pesquisa do presente trabalho.

O conceito consiste em uma forma de desenvolvimento, adaptada aos ambientes não urbanos de países em desenvolvimento, que seja baseada no uso consciente dos recursos locais pautado no conhecimento tradicional da comunidade local, garantindo assim, a manutenção dos recursos para as futuras gerações.

O economista Ignacy Sachs (1986) se apropria posteriormente de tal conceito e estabelece como pressuposto incondicional de tal conceito os três pontos: a eficiência econômica, a justiça social e a prudência ecológica. ${ }^{6}$ Sachs acredita no crescimento sem prejuízos econômicos, e para a operacionalização de tal conceito defende a forte relação de conhecimento das culturas e do ecossistema, quais os dilemas cotidianos das pessoas envolvidas e quais as técnicas que ali desenvolvem. Enfatiza a importância da participação da comunidade envolvida no planejamento das estratégias e nos processos decisórios para que esta se estabeleça sem ser dominada por outras culturas em geral consideradas superiores (LAYRARGUES, 1998).

Pontua ainda o autor que as soluções escolhidas devem respeitar o contexto histórico ecológico e cultural presente, além de priorizar a autonomia na tomada de decisões dos envolvidos por meio de planejamento. Tais soluções não sugerem a tentativa de negar as sociedades industriais que fazem parte de seu complexo, nem negar o progresso. Sachs defende que as tecnologias intermediárias não podem atender a todas as demandas, e por isso sugere o pluralismo tecnológico como esquema mais conveniente, de acordo com a necessidade em questão.

Assim, pode-se extrair do conceito de ecodesenvolvimento a necessidade de busca, pelas próprias sociedades, de um nível de equilíbrio entre a satisfação das necessidades

\footnotetext{
${ }^{6}$ O economista, ao final da década de 1980, apropria-se de tal conceito e o desenvolve conceitual e operacionalmente, criando um quadro de estratégias ao ecodesenvolvimento (LAYRARGUES, 1998).
} 
humanas e o consumo dos recursos naturais, para que, com autonomia e parcimônia, se possa promover a preservação dos bens naturais ao longo das futuras gerações.

\subsection{4 - Comunidades Sustentáveis e Etnoconservação}

Baseado na definição de ecodesenvolvimento proposta por Sachs, a manutenção de uma sociedade sustentável deve resgatar sobretudo o conceito de bem-estar e qualidade de vida das sociedades humanas. Assim, há a demanda pela elaboração de possíveis formas de organização de sociedades sustentáveis baseadas nos valores históricos, culturais e nas relações existentes entre os cidadãos e a natureza. Tal paradigma só criará bases fortes com a consciência da existência de diversidade entre os povos, fato este dificilmente constatado se levar-se em consideração a pressão para uma homogeneização sociocultural mundial expressa pelo sistema capitalista.

Uma comunidade sustentável deve basear-se em uma harmoniosa relação entre a comunidade e a natureza e para isso é indispensável que essa relação se crie com bases que respeitem os elementos culturais e históricos que caracterizam essa sociedade. Diegues (2002) afirma que a implantação do conceito de comunidades sustentáveis traria consigo consequências positivas para a prática da sustentabilidade, como a manutenção dos processos ecológicos fundamentais e a preservação das diversidades genéticas e biológicas.

Nesse sentido alguns trabalhos vêm sendo desenvolvidos relacionando a manutenção da diversidade biológica com a diversidade cultural. Tais estudos comprovam que diversas comunidades tradicionais, pescadores, indígenas e caiçaras, representam agentes responsáveis por mecanismos de manutenção da diversidade biológica. $O$ estabelecimento de áreas de proteção acaba sendo um fator de redução da diversidade cultural, pois impossibilita o habitante local de regular a maneira como se desenvolve esta forma de manejo.

Tal configuração é muito recorrente nos países em desenvolvimento, em sociedades que sofrem menos a influência dos grandes centros econômicos. As comunidades pesquisadas são um exemplo dessas populações que possuem forte vínculo cultural com o meio ambiente em que vivem, e a partir do seu modelo de produção, acabam desenvolvendo formas de manejo dos recursos naturais. É importante que essas comunidades sejam observadas, pois a manutenção da diversidade ecológica nos países em desenvolvimento depende da atuação das mesmas.

\footnotetext{
"A conceituação de sociedades sustentáveis, baseada na necessidade de se manter a diversidade ecológica, social e cultural dos povos, das culturas e modos de vida nos parece não somente mais substantiva, mas portadora dos grandes desafios. Ela relança, de alguma forma, a necessidade de se criarem novas utopias para o século XXI. Ela acena para a necessidade de se pensar na diversidade de
} 
sociedades sustentáveis, com opções econômicas e tecnológicas diferenciadas, voltadas principalmente para o 'desenvolvimento harmonioso das pessoas' e de suas relações com o conjunto do mundo natural." (DIEGUES, 2002, p.6).

O conhecimento acumulado pelas comunidades tradicionais permite o manuseio, a classificação, e a domesticação da biodiversidade respeitando os limites do crescimento. Todo o saber-fazer dessas comunidades é desenvolvido e repassado oralmente geração após geração. Para muitas sociedades, especialmente as indígenas, existe uma ligação entre o mundo natural, o sobrenatural e a organização social, o que faz inexistir a classificação dualista entre o natural e o social, sendo ambas as coisas uma coisa só (DIEGUES, 2005a). Isso somado à existência da ciência moderna aponta para a criação de uma nova ciência e prática, a etnoconservação, baseada na síntese do conhecimento das práticas científicas e tradicionais. É necessário o reconhecimento das sociedades tradicionais como formas alternativas à ciência moderna para a compreensão do meio ambiente.

\subsection{5 - Arquitetura de baixo impacto socioambiental}

Diante das questões levantadas, a produção da arquitetura, assim como tantas outras práticas envolvidas, tende a sofrer uma reflexão sobre a postura que resultaria em uma prática adequada referente a tais questões. A concepção do espaço está diretamente relacionada à construção, à utilização de recursos materiais e aos processos para transformá-los, por mais simples que estes sejam. Questões como escassez de recursos materiais e energia serão sempre presentes no contexto altamente consumidor da construção civil. Assim, a busca por uma arquitetura de baixo impacto social e ambiental pode estar ligada a uma adequada articulação entre novas tecnologias e tradições construtivas existentes, conforme o conceito de pluralismo tecnológico de Sachs (1986), já citado anteriormente.

As duas principais vertentes sobre formas de desenvolvimento de uma arquitetura de baixo impacto socioambiental são a da alta e da baixa tecnologia da construção. Não há regra para a aplicação de cada uma dessas vertentes, dependendo de questões particulares decorrentes de itens como:

- Contexto local: geográfico, econômico, social e cultural;

- Localização: urbana ou rural;

- Recursos materiais disponíveis no local

- Programa do edifício. 
Assim, é difícil denominar uma prática sustentável sem compreender todo ciclo produtivo pelo qual ela passa, mas é importante compreender que nada é absoluto em termos de arquitetura de baixo impacto socioambiental, e que cada caso deve ser analisado de maneira integrada. Um novo material ou sistema construtivo que gera excelentes resultados em termos de economia de energia e matéria em seu processo construtivo pode ser extremamente nocivo sob o aspecto social, por exemplo. É necessária uma visão sistêmica para compreender muitos equívocos frequentemente cometidos no universo da pesquisa sobre a arquitetura de baixo impacto social e ambiental.

Considerando o recorte da pesquisa em questão, há na concepção de arquitetura a expectativa de assimilar a evolução tecnológica da construção civil sem esquecer a arquitetura tradicional que valoriza o saber popular e seu espírito construtivo funcional. Há a busca do exercício de recuperação desse saber coletivo e de suas técnicas históricas, fortalecendo-as com a pesquisa de alternativas pertinentes ao contexto pesquisado.

Assim, a arquitetura de baixo impacto social e ambiental configura-se como uma resposta ao meio no qual se insere. Esse caráter contextual faz com que características geográficas, econômicas, sociais, culturais, de território, de recursos disponíveis e das demandas sociais locais sejam fatores determinantes da arquitetura a ser produzida.

\section{2 - O recorte em questão: Vale do Ribeira}

\subsection{1 - História e Memória}

Dentro da temática descrita, o universo da pesquisa centra-se no Vale do Ribeira, SP; mais precisamente nas comunidades caiçaras ${ }^{7}$ do litoral sul de São Paulo. É tão forte a relação que o habitante local tem com a geografia que o meio natural teve grande importância na conformação dos espaços e das relações humanas, sendo o Rio Ribeira de Iguape o ícone maior. Os inúmeros sambaquis encontrados na região testemunham a existência de civilizações pré-históricas ligadas ao extrativismo e à pesca.

Historicamente a região alterna períodos de prosperidade com períodos de grande decadência. Importantes ciclos econômicos como o do ouro e do arroz garantiram à região um notável patrimônio arquitetônico. A decadência desses ciclos econômicos também trouxe ao litoral paulista um caráter de desintegração. Devido a sua posição de isolamento geográfico com o planalto, a região esteve à parte de todo dinamismo econômico existente no "Serra Acima", conservando mais suas, lendas, costumes, crenças e tradições. Assim, criaram-se as bases para interpretação de que tais comunidades caiçaras se constituíram em

\footnotetext{
${ }^{7}$ Define-se como caiçaras os habitantes do litoral da região sudeste contidos entre o norte do litoral de Paraná e o sul do litoral do Rio de Janeiro, que caracterizam-se pela prática de atividades agrícolas, extrativistas e de pesca (DIEGUES 2005a).
} 
"comunidades isoladas", permanecendo imunes ao desenvolvimento capitalista (VALENTIN, 2005).

O isolamento físico somado às lacunas historiográficas fizeram com que as pesquisas de caráter histórico-antropológicos ficassem muito limitadas até meados da década de 1970, sendo que o registro histórico das "pessoas comuns" era inexistente na história oficial. A partir dos anos 1970, a vertiginosa transformação social ocorrida nas comunidades caiçaras fez com que a atenção dos estudiosos e pesquisadores voltasse-se a tal campo de investigação. E ao invés de utilizar a tradicional descrição do objeto de pesquisa, começa-se a trabalhar por meio de entrevistas, na tentativa de uma maior aproximação com a tradição oral que é tão familiar ao caiçara na manutenção de sua cultura.

\subsection{2 - Culturas Construtivas}

Nas ciências sociais, uma cultura pode ser definida como uma perspectiva do mundo através da interação de pessoas ao longo do tempo. É essa cultura que define valores, crenças, verdades, metas e regras para a identidade de uma manifestação coletiva. É nítida nas comunidades tradicionais estudadas a forte identificação cultural e social do homem com o espaço geográfico, como um reconhecimento com o território construído e apropriado. Essa aproximação traduz às estratégias de conhecimento dessas comunidades, um pensamento empírico/lógico/racional que se relaciona com o universo mitológico e simbólico e que se mantém em constante modificação. Assim, a cultura construtiva desse coletivo está intimamente ligada ao meio no qual está inserida, na eleição de materiais, processos, sistemas e organizações sociais que irão resultar no espaço construído escolhido para acolher os valores estabelecidos pela comunidade. Nesse exercício de busca pelas premissas de ordens sociais, culturais e tecnológicas locais para a definição de um sistema construtivo é importante compreender e respeitar os saberes tradicionais coletivos. A integração do caiçara com o ambiente é tamanha que o habitante faz-se o artífice de seu meio, sendo hábil a executar as mais diversas atividades artesanais, manuais, ou especializadas.

"Forçado pelo meio que vive, praiano é o homem que toca todos os instrumentos, como vulgarmente se diz, pois a necessidade de fazer a própria canoa, transformou-o no hábil carpinteiro da ribeira, mestre de construções navais, levando-o a realizar todos os trabalhos concernentes à arte, como a casa em que mora, o "tráfico", para a farinha, artigos de cerâmica, tecimento de palhas para coberturas, esteiras de peri, violas e até violinos, caixas delicadas e uma infinidade de objetos de uso domestico. É proverbial a facilidade com que se adaptam aos mais diferentes misteres, substituindo a oficiais artífices, como geralmente acontece, transformando-se em mecânicos e tanoeiros, maquinistas e pintores." (ALMEIDA, 2005, p.51). 
Na construção naval os caiçaras são especialistas na confecção de canoas de grande dimensão. Na região sul do litoral, próximo a Cananeia e Iguape, são muito fabricadas as canoas ribeiranas, compostas por madeira clara e leve, como a guapuruvu, justificando a especialidade no uso de tal material encontrado na região. Outro material comumente empregado para as construções locais era a cal extraída das cascas de ostras e berbigões provenientes dos sambaquis.
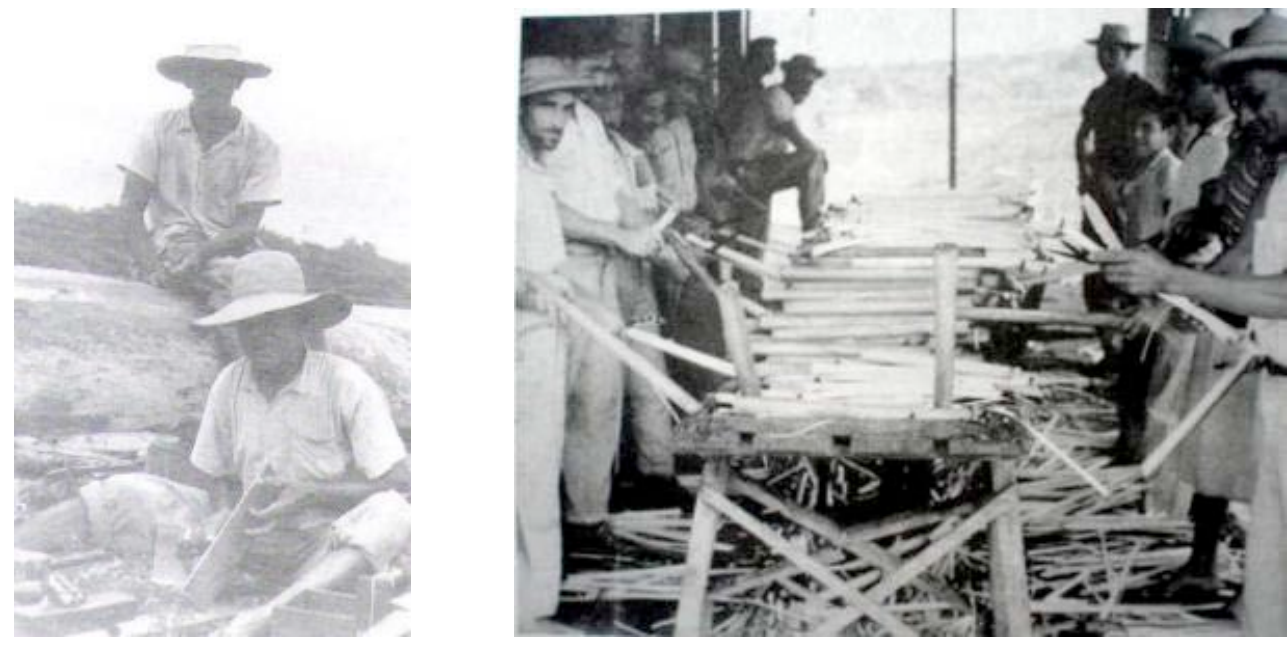

Figuras 9 e 10 - Caiçaras consertando canoa e produção de palmito em Iguape na década de 1940.

Fonte: http://my.opera.com/perfeito/albums.

No que diz respeito às construções habitacionais, a arquitetura popular desenvolvida no local, como toda arquitetura popular no país, traz consigo um aspecto de simplicidade na medida em que é composta pelos materiais que são encontrados no meio, sempre indicando uma vinculação com a natureza em virtude das limitações econômicas e sociais às quais está sujeita. Desta forma, a adaptabilidade é uma característica das culturas populares (WEIMER, 2005).

\footnotetext{
“O regionalismo não é apenas uma questão 'de usar materiais locais disponíveis', ou copiar algumas formas simples de construção usadas pelos nossos antepassados, na ausência de algo melhor, um ou dois séculos atrás. As formas regionais são as que mais de perto respondem às condições reais da vida e que melhor conseguem fazer que um povo se sinta completamente em casa, dentro do seu meio: elas não apenas utilizam o solo, mas refletem as condições correntes da cultura da região." (JORGE, 1999, p.93,94).
}

O respeito à tradição cultural não impede que a arquitetura descrita seja criativa em termos de imaginação formal e dos materiais de construção. Justamente por não ter uma intenção formal específica como a arquitetura erudita, a arquitetura popular é livre e ensina 
que, sendo a forma plástica o resultado da técnica e materiais empregados, essa arquitetura oferece uma grande quantidade de soluções (WEIMER, 2005).

Quanto às técnicas construtivas tradicionalmente empregadas no local, as principais são o pau-a-pique simples, o pau-a-pique barreado (Fig. 11 e 12), e a casa de madeira (Fig. 14 e 15). As coberturas mais usuais são confeccionadas em telhas tradicionais, sapê e folhas de palmeiras ${ }^{8}$, materiais encontrados em igual proporção . O piso, dependendo do uso empregado, varia. Na sala é comum o uso do assoalho de madeira; já na cozinha e quarto terra batida. Mesmo quando o restante da construção é feito em outro material, a cozinha, que apresenta maior uniformidade em sua construção, é construída em pau-a-pique (MÜLLER, 2005).

Ainda segundo Müller (2005), a planta básica da habitação caiçara conta com três peças indispensáveis: sala, quarto e cozinha. Cada uma delas constitui uma unidade do corpo geral da casa, muitas vezes feita com materiais diferentes, marcando a construção da casa em etapas, de acordo com a disponibilidade do material. Conforme Figura 15, a casa pode ser dividida em três lances: 10 frente (sala), 2으 centro (corredor que une frente ao fundo e sala) e 3 o último (cozinha). A sala tem a função mista de depósito, despensa e celeiro, com apenas alguns bancos como mobiliário. O quarto conta com um ou dois jiraus ${ }^{9}$, caixotes apoiados servindo como armários, e roupas penduradas. A cozinha não possui janelas, apenas uma porta para acesso externo, e é iluminada e arejada pela luz e ar que entra pelas frestas das paredes. Seu piso é sempre de terra batida, já que o fogo é feito sobre o próprio chão, a panela é suspensa pelo teto ou apoiada em um tripé de ferro ${ }^{10} \mathrm{Na}$ cozinha há a tríade constituída em seu ambiente: o pilão, a engenhoca para a moagem e o "tráfico"11. Constam as três partes: a roda, a prensa e o forno.
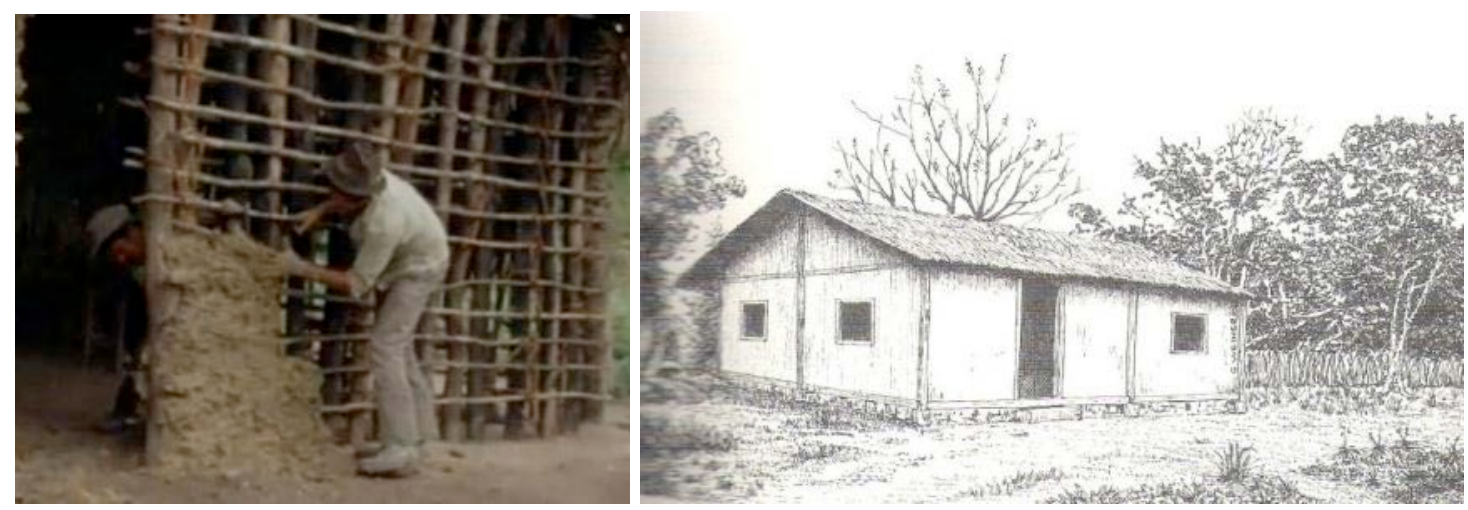

Figuras 11 e 12 - Barreado do pau-a-pique e casa de pau-a-pique no Vale do Ribeira.

\footnotetext{
${ }^{8}$ Especialmente a juçara, palmeira que produz palmito muito encontrado no litoral

${ }^{9}$ Também conhecido como tarimba: cama rústica, feita por estrados de pau recobertos por uma esteira.

${ }^{10}$ Também conhecida como trempe.

${ }^{11}$ Conjunto de peças para a fabricação doméstica da farinha de mandioca, base da alimentação do praiano.
} 

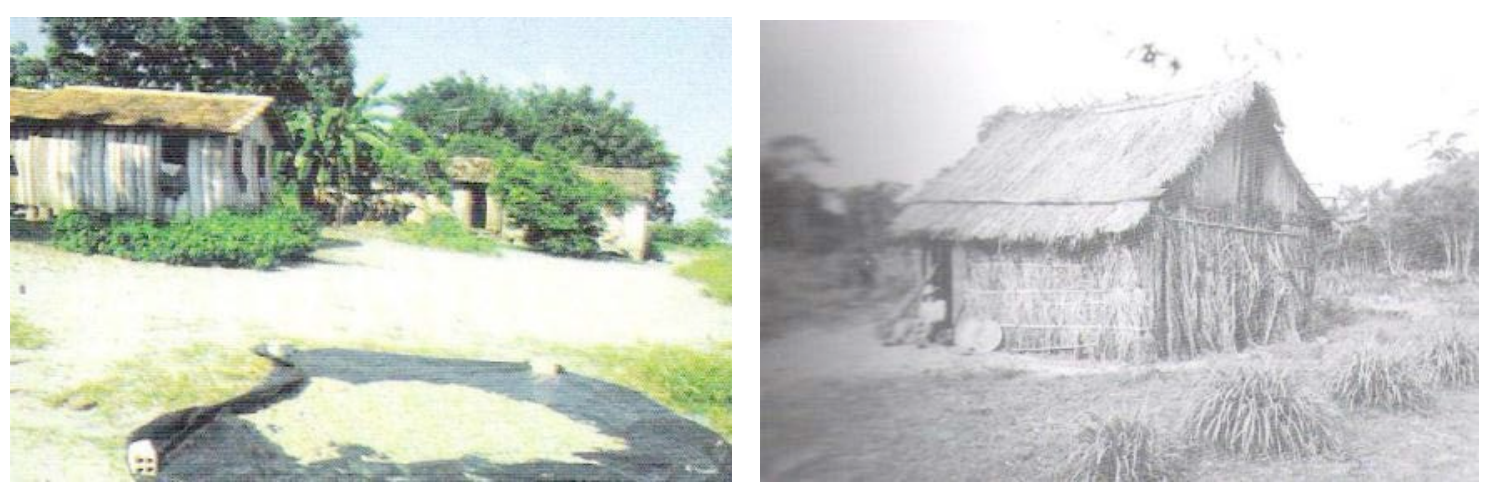

Figuras 13 e 14 - Casa de madeira e cobertura em folhas de palmeiras no litoral paranaense.

Fonte: DIEGUES 2005.
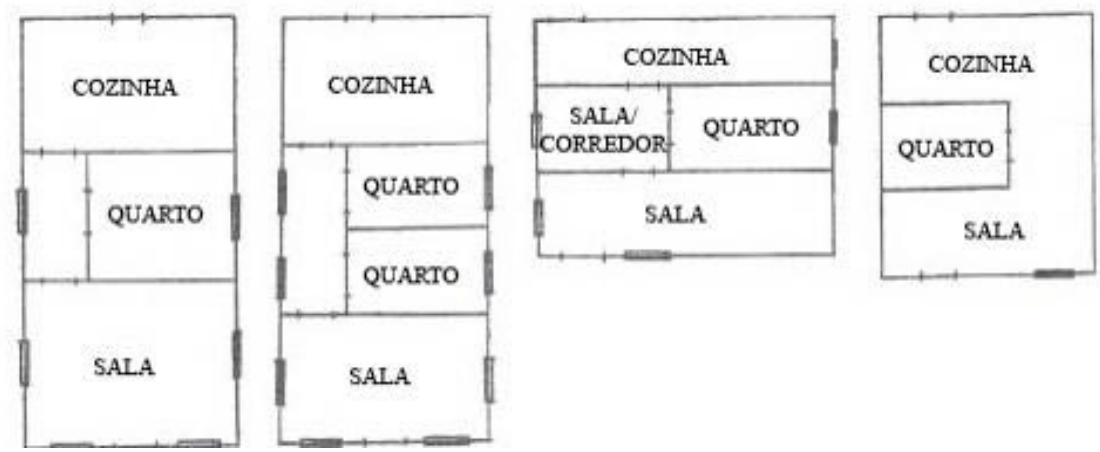

Figura 15 - Plantas padrão das habitações caiçaras unifamiliares no bairro do Icapara.

Fonte: DIEGUES 2005.

"Por sua disposição geral, pela aparência e composição de cada uma de suas dependências, a casa do praiano é um verdadeiro espelho a refletir a vida do seu morador: simples em suas necessidades, produtiva, procurando ser ao máximo autossuficiente pelo beneficiamento doméstico dos produtos que lhe servem de alimento." (MÜLLER, 2005, p. 102).

Em contato com o mar e a terra, o caiçara possui um gênero de vida misto, conciliando as atividades de pesca e agricultura que se processam em diferentes períodos do ano. Muitas vezes, essas atividades que correm simultaneamente acabam por criar outra forma de organização produtiva, onde é comum a prática de técnicas agrícolas e de pesca coletivas, baseadas em colheitas feitas em regime de mutirão. 


\subsection{3 - Questões Contemporâneas}

A partir dos anos 1960, o litoral paulista e as comunidades caiçaras sofrem uma série de transformações. Com a abertura de estradas rumo ao litoral, a região recebe grande número de veranistas, acarretando a compra de grande parte do território pelos empreendedores. Os caiçaras, habitantes originais, sofreram um violento processo de expulsão de seu território por não possuírem posse legal dessas terras. A consequência dessa valorização imobiliária foi o crescimento de ocupações irregulares em encostas de serras, locais sujeitos a desabamento, onde tampouco a posse legal era existente (DIEGUES 2005). Assim, tal movimento deu início a um processo de favelização da comunidade caiçara, no qual as novas construções acabaram perdendo muitas das características da construção regional, transformando-se em construções desintegradas, descaracterizadas (Fig. 16 e 17).

Outra questão contemporânea foi a transformação de grande parte do território caiçara em unidades de conservação. Apesar de a medida até certo ponto ser capaz de frear a especulação imobiliária, os caiçaras, impedidos de fazer a maior parte das suas atividades como fazer roça, extrair madeira para canoas e moradias, entre outras, acabaram tendo seus direitos civis ameaçados. Pela baixa densidade de exploração e pelos conhecimentos e práticas culturais no uso dos recursos naturais, a ação caiçara na extração de recursos junto ao meio ambiente pouco traria prejuízos para a manutenção das espécies, ao contrário, exerceria um papel regulador dos recursos, uma vez que deles dependem para viver. A política ambiental inadequada e a especulação imobiliária são os principais processos sociais atuais que atingem o modo de vida caiçara, enfraquecendo as relações sociais e suas noções culturais.
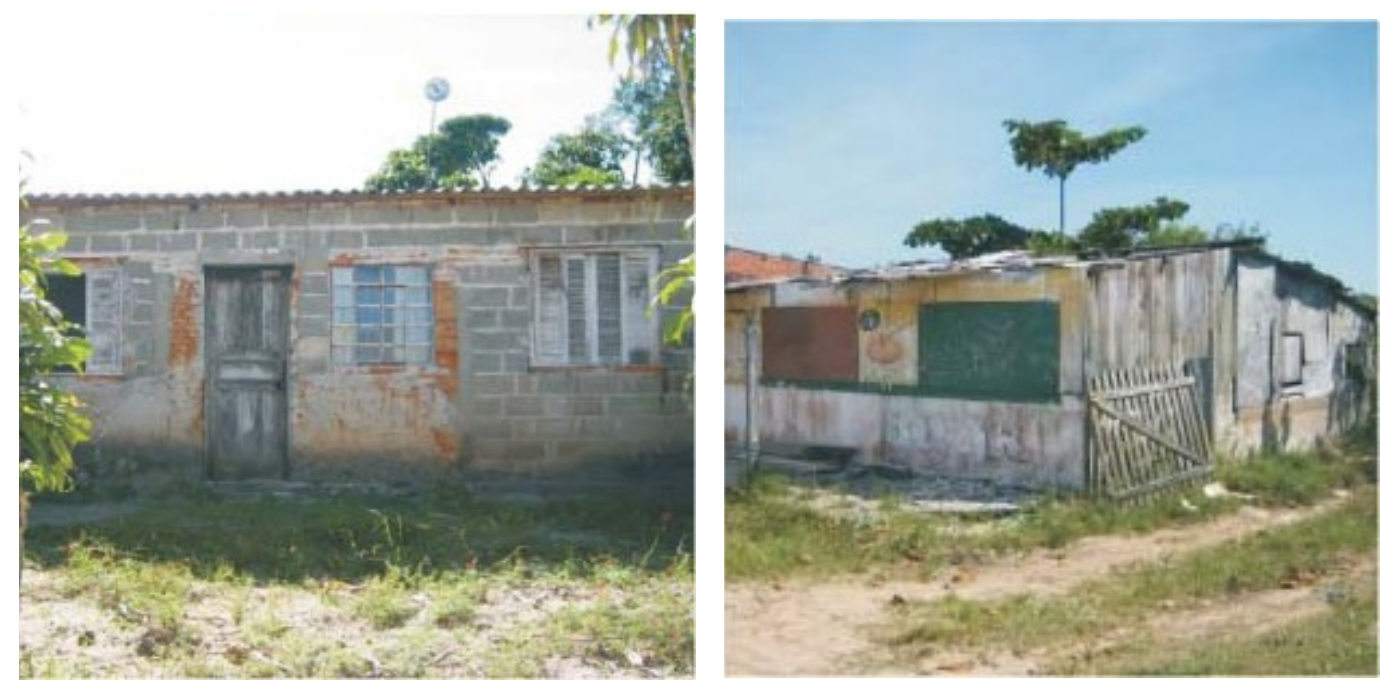

Figuras 16 e 17 - Exemplos de autoconstrução recente na Barra do Ribeira.

Fonte: Autoria própria. 


\subsection{4 - Desenvolvimento sustentável no Vale do Ribeira}

A condição socioeconômica atual do Vale do Ribeira é decorrente em grande parte desse seu processo de evolução histórica. A parte mais significativa de sua produção econômica corresponde à comercialização de produtos naturais, como o extrativismo natural e pesqueiro e a produção agrícola. Essas atividades, já prejudicadas por não agregarem tanto valor a sua produção, são ainda agravadas se consideradas em um mercado onde os concorrentes têm a vantagem de maiores aportes tecnológicos e mão-deobra qualificada. Já no setor secundário, a região apresenta poucos estabelecimentos, e uma absorção de mão de obra pequena, situada principalmente nos setores de mineração.

A agricultura ainda é a principal atividade econômica, sendo representada principalmente pelas culturas do chá e banana. Isso devido à importância da pequena propriedade rural no Vale. A maior parte da mão de obra agrícola absorvida no setor é encontrada em pequenos núcleos agrícolas distante dos grandes centros. Dados do Censo Agropecuário de 1995-1996 do IBGE registraram que 35,95\% dos estabelecimentos agropecuários da região de Governo de Registro tinham menos de 10 hectares, enquanto que a média estadual era da ordem de $29,95 \%$

Ha também parte da população que se beneficia da extração e venda do palmito e plantas ornamentais. E necessário lembrar que essas atividades, apesar de ainda praticadas e expressivas na economia da região, configuram- se hoje como ilegais, em função da legislação das últimas décadas e a criação das unidades de conservação

As tabelas que seguem sintetizam e demonstram, através de alguns índices sociais , o panorama de alguns municípios localizados no Vale do Ribeira.

Tabela 1 - Índices do Vale do Ribeira.

Fonte: IBGE 1996.

\begin{tabular}{|c|c|c|c|c|c|c|c|}
\hline MUNICÍPIO & $\begin{array}{c}\text { Renda per } \\
\text { Capita } \\
\text { (Em R\$) }\end{array}$ & $\begin{array}{l}\text { Índice de } \\
\text { Longevid. } \\
\text { (IDHM-L) }\end{array}$ & $\begin{array}{l}\text { Índice de } \\
\text { Educ. } \\
\text { (IDHM-E) }\end{array}$ & $\begin{array}{c}\text { Índice de } \\
\text { renda } \\
\text { (IDHM-R) }\end{array}$ & $\begin{array}{c}\text { Índice de } \\
\text { Desenvolv. } \\
\text { Humano Munic. } \\
\text { (IDH-M) }\end{array}$ & $\begin{array}{c}\text { Classific. } \\
\text { na UF }\end{array}$ & $\begin{array}{l}\text { Classific. } \\
\text { Nacional }\end{array}$ \\
\hline Cananéia & 229,18 & 0,814 & 0,830 & 0,680 & 0,775 & 360 & 1190 \\
\hline São M. Arcanjo & 225,27 & 0,782 & 0,848 & 0,677 & 0,769 & 404 & 1350 \\
\hline Jacupiranga & 267,27 & 0,743 & 0,830 & 0,706 & 0,759 & 475 & 1601 \\
\hline Cajati & 170,53 & 0,814 & 0,807 & 0,631 & 0,751 & 531 & 1863 \\
\hline Tapiraí & 220,93 & 0,733 & 0,808 & 0,674 & 0,738 & 583 & 2193 \\
\hline Eldorado & 173,05 & 0,743 & 0,823 & 0,633 & 0,733 & 602 & 2353 \\
\hline Sete Barras & 159,39 & 0,763 & 0,812 & 0,619 & 0,731 & 605 & 2398 \\
\hline Apiaí & 171,29 & 0,673 & 0,845 & 0,631 & 0,717 & 623 & 2683 \\
\hline Capão Bonito & 184,95 & 0,673 & 0,830 & 0,644 & 0,716 & 625 & 2699 \\
\hline Guapiara & 167,90 & 0,688 & 0,801 & 0,628 & 0,706 & 632 & 2901 \\
\hline Ribeirão Grande & 161,85 & 0,688 & 0,805 & 0,622 & 0,705 & 633 & 2907 \\
\hline Iporanga & 135,50 & 0,688 & 0,798 & 0,592 & 0,693 & 638 & 3113 \\
\hline Barra do Turvo & 113,89 & 0.670 & 0,755 & 0,563 & 0,663 & 641 & 3566 \\
\hline
\end{tabular}


Diante de tal cenário, o Governo Federal recentemente contribuiu com iniciativas em políticas públicas que beneficiem a região em aspectos sociais e ambientais deficitários. Foi criado em 2004, no âmbito do programa Fome Zero, um programa executado pelo Ministério de Desenvolvimento Social (MDS) e Combate à Fome, por meio da Secretaria Extraordinária de Segurança Alimentar e Nutricional com o objetivo de garantir maior inserção socioeconômica de tal região. Outros programas de desenvolvimento territorial sustentável, como o Programa de Desenvolvimento Territorial, do Ministério do Desenvolvimento Agrário (MDA) e do Programa da Agenda 21 do Ministério do Meio Ambiente (MMA) também vem contribuindo para a promoção do desenvolvimento sustentável no Vale do Ribeira.

Os três Ministérios, MDA, MMA e (MDS) trabalham juntos para o desenvolvimento da região e para intermediar tais relações, o Consórcio de Segurança Alimentar e Desenvolvimento Local (CONSAD) foi criado, como fórum democrático de discussão de tais ações. O CONSAD é uma associação privada sem fins lucrativos, entre municípios, que vem se construindo na região do Vale do Ribeira, com a participação do poder público e da sociedade civil. Tal instituição manifestou a necessidade de desenvolvimento de um plano para um Projeto de Desenvolvimento Territorial Sustentável para o Vale do Ribeira, e elegeu o Instituto para Desenvolvimento Sustentável e Cidadania no Vale do Ribeira (IDESC) entidade responsável para tal elaboração.

Além do MDS, que vem liberando recursos para apoio ao desenvolvimento local, programas como o Programa Nacional de Desenvolvimento Territorial, do MDA, têm apoiado a agricultura familiar financiando projetos que são pactuados como prioritários pela comunidade local (governos e sociedade civil do território). Por sua vez, o MMA apresenta a proposta de apoiar a construção de uma importante ferramenta - a Agenda 21, aqui denominada de Plano de Desenvolvimento Territorial Sustentável - para a construção do Desenvolvimento Sustentável do Vale do Ribeira.

Assim, em novembro de 2004, o MMA publicou edital propondo o apoio financeiro para a elaboração de um Plano de Desenvolvimento Territorial Sustentável para o Vale do Ribeira e implantação de projetos socioambientais prioritários, abrangendo 32 municípios, sendo 7 localizados na porção territorial do Paraná. Entre os critérios estabelecidos pelo edital, constava que a instituição proponente deste projeto deveria ser entidade-membro do CONSAD Vale do Ribeira.

Nesse contexto, em reunião do Fórum CONSAD, realizada em 2004, o IDESC foi a entidade eleita para ser proponente do Projeto, devendo, entretanto, assegurar o fórum 
CONSAD como instância maior de pactuação e deliberação sobre todo o processo de implantação do Projeto.

Para facilitar o trabalho de articulação e mobilização do projeto, o território do Vale do Ribeira foi dividido em 12 microrregiões e, cada uma dessas regiões, contou com a atuação de uma instituição mobilizadora com a responsabilidade de articular o trabalho. A microrregião II, onde se incluem os municípios de Iguape, Cananéia, Ilha Comprida, Pariquera-Açu, é o principal objeto de estudo neste trabalho.

Segundo o relatório produzido em conferência das microrregiões II e VI realizada em Registro:

"O desenvolvimento territorial sustentável do Vale do Ribeira deve promover integralmente a qualidade de vida de toda a população local, aumentar a autoestima e a esperança da geração atual e garantir os direitos socioambientais das gerações futuras. Deve atender às necessidades básicas de serviços de educação integral de qualidade, saúde, segurança alimentar, regularização fundiária de terra, geração de trabalho e renda, com investimentos em infraestrutura e nas políticas de inclusão social e de combate à pobreza, respeitando o meio ambiente e todas as formas de vida, garantindo a conservação e o uso dos recursos naturais de uma forma equilibrada e consciente. Deve ser com base nos processos democráticos e participativos, no reconhecimento e no respeito mútuo à nossa diversidade social, cultural, religiosa, econômica e política e de gênero.

$\mathrm{Na}$ atualidade o processo hegemônico de desenvolvimento no Vale do Ribeira é caracterizado pela concentração de riquezas e depredador dos recursos naturais, como gerador da exclusão social. Os principais entraves ao desenvolvimento regional são: a falta de infraestrutura, as leis ambientais restritivas sem políticas compensatórias e não incentivadoras do desenvolvimento sustentável, a falta de regularização fundiária das terras, as leis ambientais restritivas, a falta da implantação de políticas de educação ambiental orientativa, tecnologia e pesquisa insuficientes e a falta de investimentos em políticas socioeconômicas inclusivas.

O diagnóstico regional impõe uma ação imediata e integrada do poder público, no âmbito municipal, estadual e federal, com a sociedade civil para combater a pobreza e gerar emprego e renda, visando reverter positivamente a realidade socioeconômica do Vale do Ribeira.

Adotar a concepção de desenvolvimento sustentável que articule as forças sociais e econômicas, a sociedade civil e o poder público e que potencialize o capital social e natural para a promoção social e econômica tendo como centro a promoção humana em todas as suas dimensões. De modo concreto, promover a qualidade de vida, garantir a geração de oportunidades de emprego, trabalho e renda, apoiar e fortalecer a agricultura familiar, a pesca, extrativismo, apicultura, turismo, promover a conservação e o uso sustentável da biodiversidade e, principalmente, buscar a solução de problemas estruturais de 
infraestrutura e a titulação de terras. O poder público deve desempenhar sua função republicana tanto na oferta de bens e serviços essenciais e universais, como no planejamento integrado. Isto se traduz na implantação de políticas públicas com qualidade, equidade e efetividade, na realização de investimentos em infraestrutura e na solução dos problemas estruturais, principalmente a regularização fundiária, com a adoção de instrumentos adequados de financiamento e fomento das atividades sociais e econômicas de modo democrático e transparente, com participação e controle social." (IDESC, 2006)

Assim, é clara a necessidade de criação de políticas públicas para a promoção de desenvolvimento sustentável na região, regulando e promovendo o bem-estar e a qualidade de vida nas mais diversas formas de manifestação humana. Uma ação efetiva da esfera pública com a participação da população no processo decisório pode representar uma interessante estratégia para condução da questão.

\subsection{5 - Pesquisa de Campo}

Como parte da metodologia, ao longo do desenvolvimento da pesquisa foram realizadas visitas ao local para a realização de trabalho de campo, traduzido em entrevistas junto aos moradores locais e levantamento de imagens fotográficas. Os questionários elaborados $^{12}$ visavam recolher informações sobre as habitações unifamiliares existentes, como, localização, uso, implantação, arranjo dos espaços, sistemas construtivos, subsistemas e infraestrutura existente. Além disso, o questionário visava também à identificação dos moradores, averiguação da idade e da ocupação, o responsável pela execução da casa, os principais inconvenientes segundo seus habitantes, e as alterações que julgavam necessárias de serem feitas. Foram entrevistadas 15 famílias nativas, excluindo-se as famílias em casas de veraneio: 5 do povoado de Jairê, 5 do povoado de Icapara e 5 da Barra do Ribeira, todos no município de Iguape.

\subsubsection{1 - Síntese de dados obtidos}

Localização pesquisa: Bairros tradicionais Icapara (33,33\%), Barra do Ribeira (33,33\%) e Jairê $(33,33 \%)$.

Uso: Estritamente Residencial (100\%).

Arranjo dos espaços: Residências térreas. Dois Dormitórios (média), Sala, Cozinha, Banheiro.

Sistemas construtivos: Bloco de concreto (53,33\%), vedação em madeira (33,33\%), e pau-apique $(13,33 \%)$.

Sistemas construtivos cobertura: Telha de fibrocimento $(53,33 \%)$ e telha cerâmica $(46,66 \%)$.

\footnotetext{
${ }^{12}$ Questionários elaborados presentes no item Apêndices.
} 
Patologia observada nos sistemas: Contato com o solo trazendo umidade. Falta de manutenção em algum componente de madeira (cobertura).

Infraestrutura existente:

Esgoto: Fossa séptica (100\%).

Água: Rede pública $(66,66 \%)$, poço $(33,33 \%)$.

Energia: Rede pública (100\%).

Vias públicas: Bloco Inter travado (40\%), Areia/terra (60\%).

Perfil dos habitantes:

Média de habitantes por casa: Três.

Ocupação: Dona de casa: 16,66\%, pescador: 25\%, funcionário publico: 8,33\%, comércio/serviços: $16,66 \%$, aposentado: $16,66 \%$, estudante: $16,66 \%$.

\section{Execução da casa:}

Quantas etapas: Duas (60\%), Uma (40\%).

Quem executou: Profissional (pedreiro) da região contratado $(66,66 \%)$, autoconstrução $(33,33 \%)$.

Quais principais inconvenientes: Muito quente (80\%), Goteiras (13,33\%), Acesso fácil de mosquitos por falta de forro $(6,66 \%)$.

Quais alterações sugerem: Aumento do pé direito: (20\%), Troca de cobertura (40\%), Mudança na implantação para diminuir a insolação (13,33\%), colocação de forro $(26,66 \%)$. 


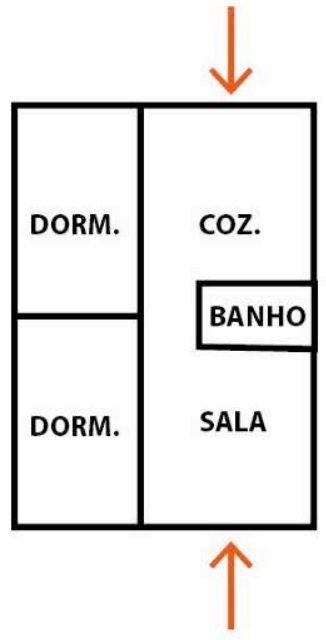

FRENTE DO LOTE

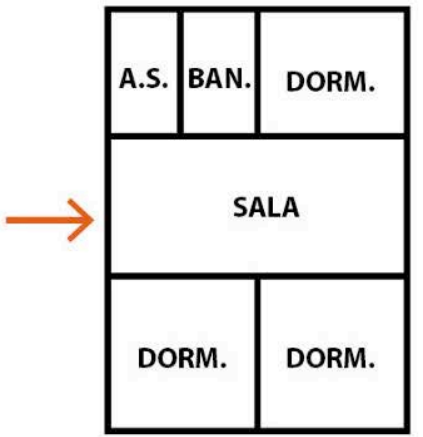

FRENTE DO LOTE

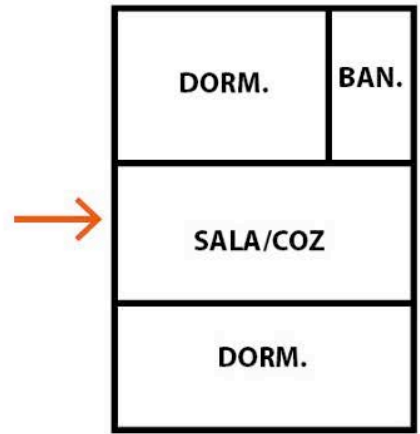

FRENTE DO LOTE

Figura 18 - Croquis principais arranjos de espaço encontrados na pesquisa.

Fonte: Autoria própria.

\subsubsection{2 - Levantamento de Imagens}
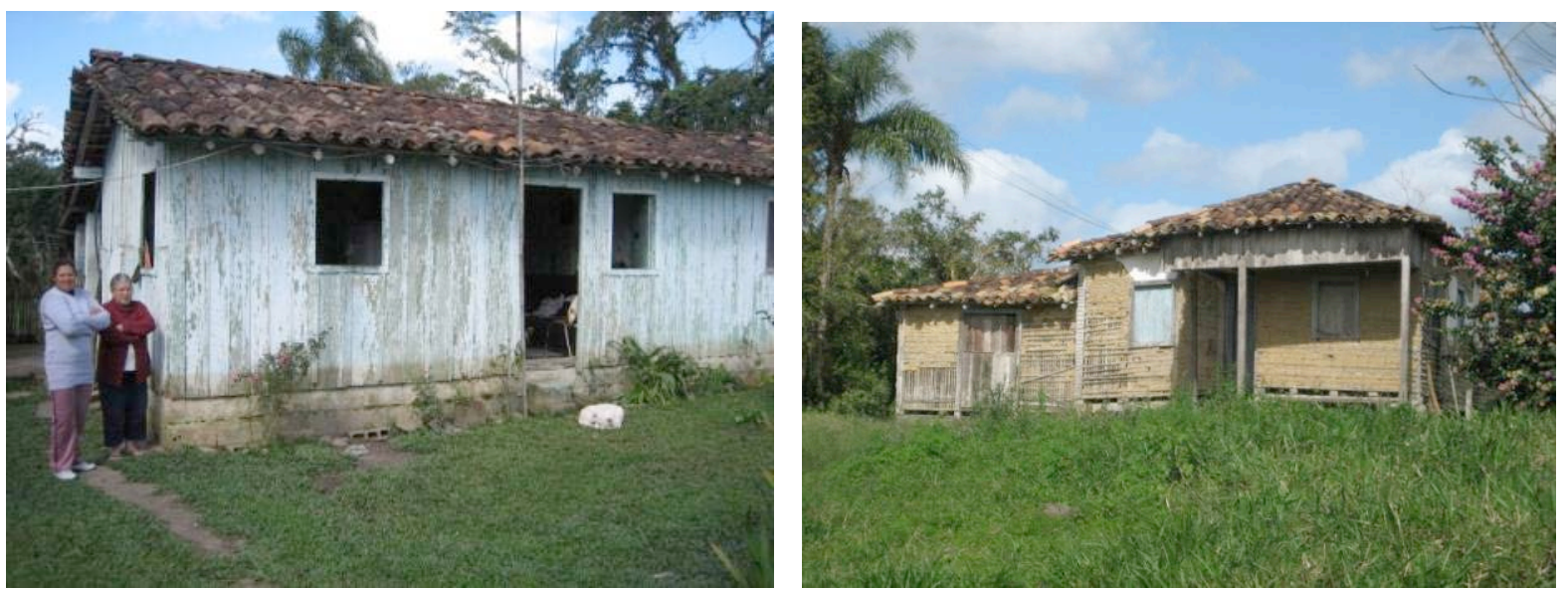

Figuras 19 e 20 - Casa em madeira e casa em pau-a-pique no Jairê, Iguape.

Fonte: Autoria própria. 

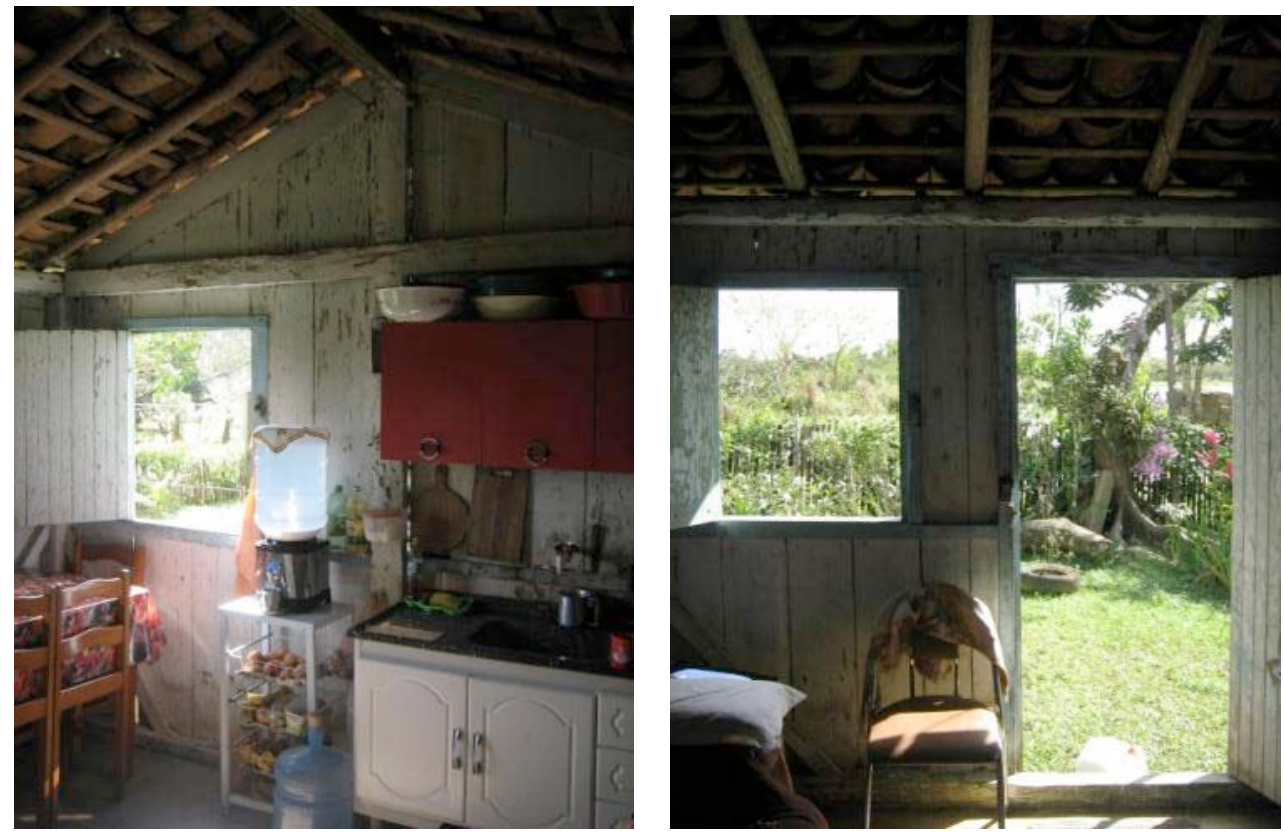

Figuras 21 e 22 - Interior de casa em madeira no Jairê, Iguape.

Fonte: Autoria própria.
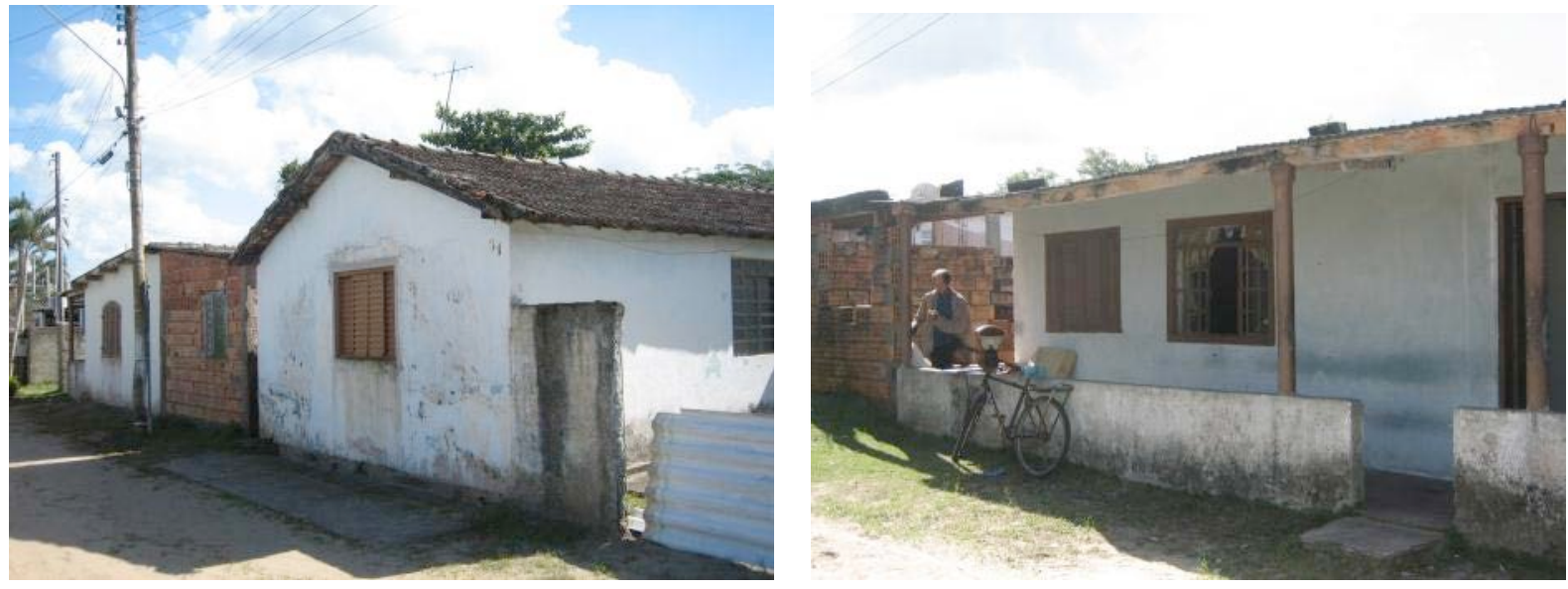

Figuras 23 e 24 - Casas em alvenaria em Icapara, Iguape.

Fonte: Autoria própria.

\subsubsection{3 - Resultados}

Baseada na análise desenvolvida a pesquisa alcançou um diagnóstico com algumas premissas. Primeiramente é importante ressaltar a grande integração do modo de vida do caiçara ao meio local. A complexidade das atividades realizadas por esses grupos assegura a manutenção de uma cultura integrada à natureza, com suas formas próprias de manejo, o que caracteriza o ideal de uma sociedade sustentável. Assim, como uma via de mão dupla, o 
complexo e parcimonioso aproveitamento dos recursos naturais locais para a subsistência promove a manutenção da cultura local, e a cultura local promove a preservação da biodiversidade do meio ambiente.

Outra importante premissa levantada é a da tradição coletiva das organizações sociais. Conforme a bibliografia existente, muitas das atividades desenvolvidas por estas populações, como a pesca, a pequena agricultura ou até mesmo as atividades de construção civil são realizadas através da cooperação interfamiliar, o mutirão. ${ }^{13}$ Apesar dessa tradição, a pesquisa de campo sinalizou que a prática do mutirão na construção civil gradativamente diminui-se, fragilizando ainda mais as relações sociais do contexto.

Apesar de tal fragilidade, a pesquisa de campo foi capaz de constatar a existência de algumas técnicas construtivas tradicionais, totalizando quase a metade das habitações existentes. As casas de madeira fabricadas em decorrência da construção naval e as casas de pau-a-pique de arquitetura rural ainda são recorrentes na arquitetura espontânea local, e a tradição ainda é passada através de gerações.

A última premissa diz respeito à familiaridade do habitante caiçara com as mais diversas atividades construtivas, o que demonstra o viés 'artífice' que esses habitantes preservam, desenvolvendo as mais diversas atividades técnicas, garantindo a autossuficiência com os recursos locais.

Assim, a proposta de um sistema construtivo aplicável para a autoconstrução na região demonstra-se não só passível de desenvolvimento mas também necessária para o fortalecimento de ações comunitárias e para a motivação de articulação social em tais povos. A pesquisa de base desenvolvida sobre o contexto social do Vale do Ribeira e sua documentação representam importantes contribuições na manutenção dos aspectos culturais desses povos, que tanto foram alvo da já discutida invisibilidade existente. É importante pensar na dimensão da pesquisa como sendo parte de um trabalho maior que pode, concretamente, atribuir uma melhoria espacial e técnica nas práticas da autoconstrução existente, valorizando a história local e o indivíduo enquanto sujeito de seu próprio espaço.

\footnotetext{
${ }^{13}$ Mutirão, na linguagem caiçara: muxirão, puxirão ou ajutório.
} 
CAPÍTULO 3 - BASE EMPÍRICA 
3.1 - O bambu como fonte de matéria-prima para a construção civil.

\subsection{1 - Introdução}

Historicamente, é inquestionável o papel desempenhado pelo bambu no desenvolvimento das civilizações Orientais, no sudeste asiático e em países como China, Indonésia, Índia e Japão. A planta apresenta uma ampla variedade de aplicações associadas às praticas humanas que se materializam até os dias de hoje. Sua matéria-prima é capaz de produzir alimentação, medicamentos, artesanato, utensílios, vestimentas, combustível e até mesmo se configurar como elemento estrutural na construção civil. Estima-se que, ainda hoje, o bambu contribua para a subsistência de mais de um bilhão de pessoas (SASTRY, 1999 apud PEREIRA; BERALDO, 2008) ${ }^{14}$.

Enquanto cultura agrícola, o bambu apresenta significativas vantagens. Trata-se de uma planta perene e altamente renovável, sem necessidade de replantio. É uma planta muito bem adaptada às condições climáticas brasileiras, sendo algumas espécies nativas ao território e outras espécies exóticas. Segundo Pereira e Beraldo (2008), o bambu é um material renovável e de baixo custo de produção, além de possuir baixo tempo de renovação e grande rendimento anual por unidade de área.

No âmbito da preservação ambiental, sua produção, além de aliviar a pressão para a exploração de madeiras pertencentes a ecossistemas ameaçados no Brasil, representa importante expressão na regeneração e proteção ambiental, reflorestando e recompondo matas ciliares, contendo a movimentação de solos e, desse modo, evitando erosões.

Mas talvez a mais importante implicação decorrente do uso do bambu no presente trabalho é o potencial de aproximação e domínio do homem em todo o processo produtivo no qual o bambu está inserido. Desde o início de seu cultivo, o bambu demanda constante presença do homem na manutenção anual de sua cultura e também no desenvolvimento de todo o processo: colheita, corte, tratamento, beneficiamento e manufatura. Pode-se concluir que representa um importante elemento de fixação e aproximação do homem ao processo de produção e às atividades artesanais, sendo consequentemente uma solução desencadeadora de uma organização social mais democrática dentro do processo produtivo.

Dessa forma, o bambu enquanto matéria-prima para a construção civil pode e deve carregar consigo a postura de uma produção voltada para escala e possibilidades mais humanas, seja na otimização dos recursos materiais, seja na autossuficiência do provimento de matéria-prima, seja em uma distribuição de trabalho socialmente mais equilibrada seja em uma produção de material mais acessível. É para essas funções que o "amigo das

\footnotetext{
${ }^{14}$ SASTRY, C. B. Timber for the 21st Century. On line. INBAR, 1999.
} 
pessoas", como notoriamente é chamado o bambu na China, deve seguir acompanhando a humanidade.

\subsection{2 - A cultura do bambu no mundo}

Segundo grande parte das fontes sobre o tema, a origem do bambu remonta o período Cretáceo, próximo ao início na era Terciária, sendo relacionada diretamente às primeiras civilizações asiáticas. O bambu está registrado nos principais elementos da ideografia chinesa pré-histórica, e a relação da planta com povos orientais como chineses, japoneses, indianos e indonésios sempre permaneceu extremamente próxima até os dias de hoje (Figuras 25 e 26).
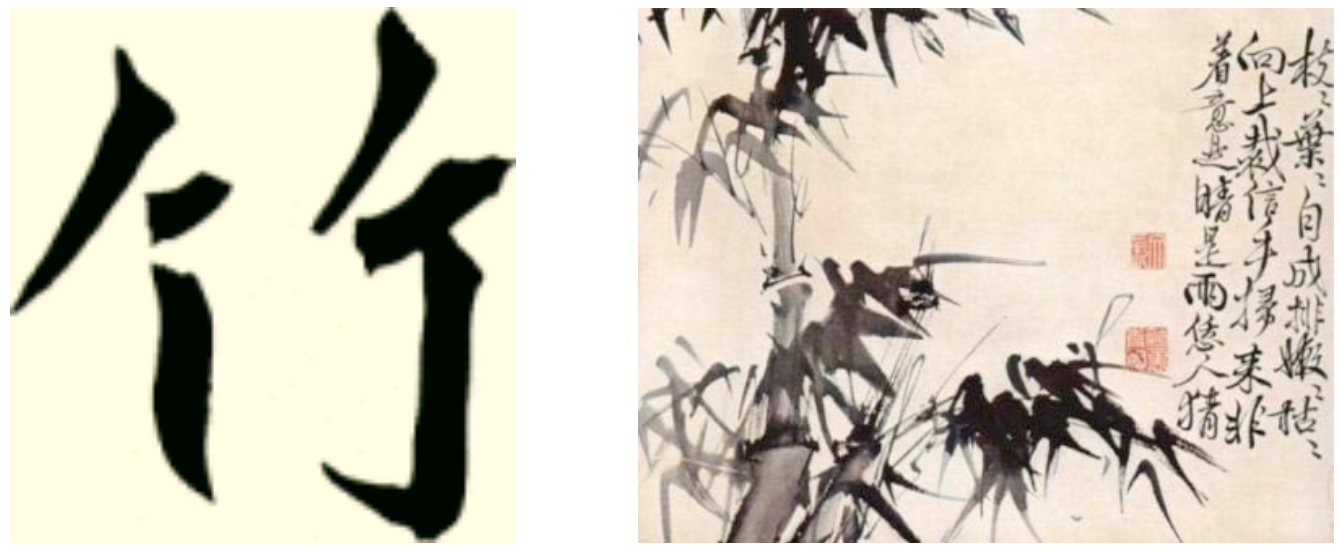

Figuras 25 e 26 - Ilustração de caractere chinês originado do ideograma pré-histórico bambu e ilustração Bamboo de Xu Wei, Dinastia Ming.

Fonte: http://www.npm.gov.tw.

Quanto à localização geográfica de sua ocorrência, a adaptabilidade do vegetal permite uma ampla distribuição abrangendo três grandes regiões: o Pacifico asiático, a África e a América. Assim, com exceção ao continente europeu, o bambu se desenvolve de maneira natural em todos os outros continentes, desde a latitude $46^{\circ}$ Norte até a $47^{\circ} \mathrm{Sul}$, e desde o nível do mar até os 4300 metros de altitude. Segundo Villegas (2003), embora a máxima altitude para o crescimento do bambu tenha se registrado na região dos Andes equatoriais, a maior parte dos bambus se adapta melhor aos habitats úmidos das florestas tropicais, sendo assim o único grupo de gramíneas adaptado inteiramente às florestas. Algumas espécies se desenvolvem em locais mais secos, mas nenhuma delas em desertos.

Segundo Hidalgo-López (2003), a distribuição continental do bambu é de aproximadamente 67\% na Ásia e Oceania, 3\% na África e 30\% nas Américas. Pertencente à 
família Graminae (gramíneas) e à subfamília Bambusaceae, os bambus são existentes em aproximadamente 1600 espécies distribuídas em possíveis 121 gêneros ( 25 herbáceos e 96 lenhosos).

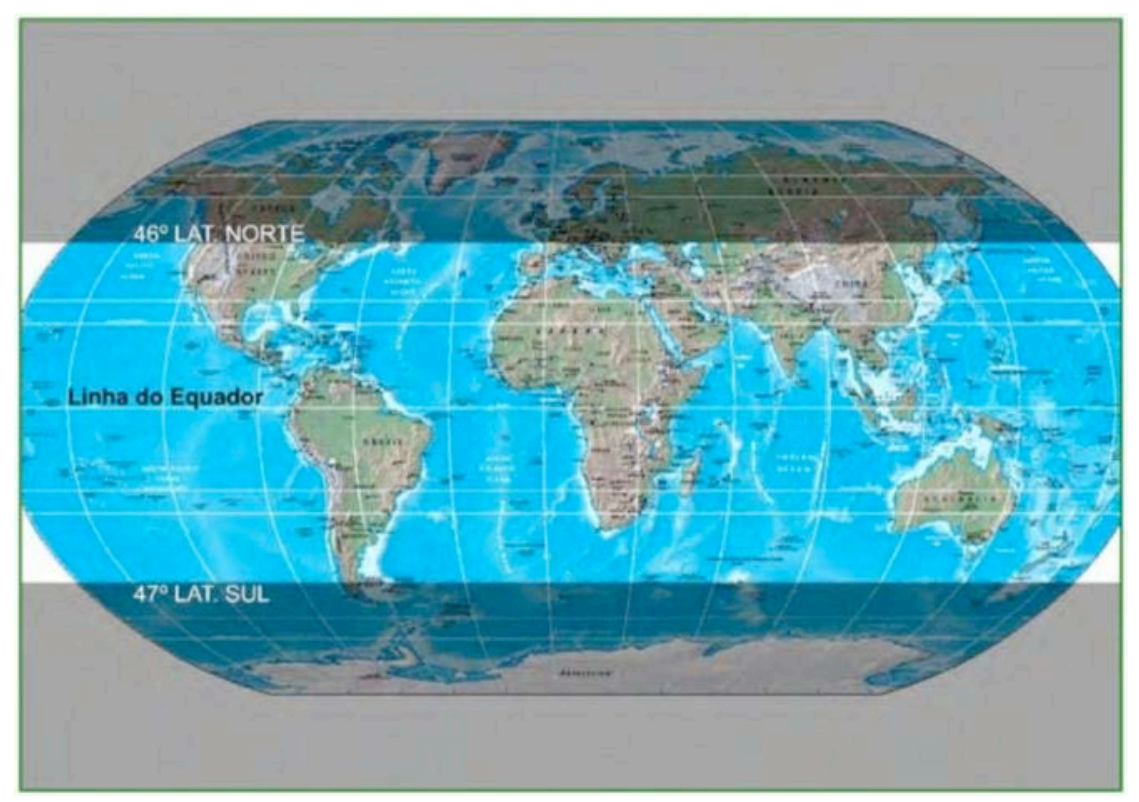

Figura 27 - Mapa da distribuição Geográfica do bambu no mundo.

Fonte: NUNES, 2005.

Na América, segundo continente em volume da distribuição do bambu, os números correspondem a, aproximadamente, 440 espécies nativas identificadas, sendo 320 lenhosas e 120 herbáceas, sendo que ainda existem muitas espécies lenhosas não identificadas. Sua distribuição em tal continente concentra-se também entre $46^{\circ}$ Norte e $47^{\circ}$ Sul, entre a zona temperada dos Estados Unidos e a Bacia do Rio da Prata na Argentina. As espécies lenhosas estão em sua maior parte localizadas entre a latitude $22^{\circ}$ Norte no México e $34^{\circ}$ Sul. Já as espécies herbáceas situam-se entre a latitude $29^{\circ}$ Norte no México e $34^{\circ}$ Sul. Verticalmente, tais espécies são raramente encontradas em altitudes superiores a 1200 metros. Assim, a América Latina é a mais rica região em termos de diversidade e número de espécies de bambus das Américas (HIDALGO-LÓPEZ, 2003).

Devido ao pequeno valor econômico ainda atribuído ao bambu, a maioria dos países latino-americanos não conta com dados que estimem as áreas cobertas com sua produção; somente a Colômbia, Nicarágua e Venezuela possuem dados nesse sentido. Entretanto, fotografias de satélite permitem estimar que existam no mínimo 11 milhões de hectares cobertos de bambu na América Latina (VILLEGAS, 2003). 


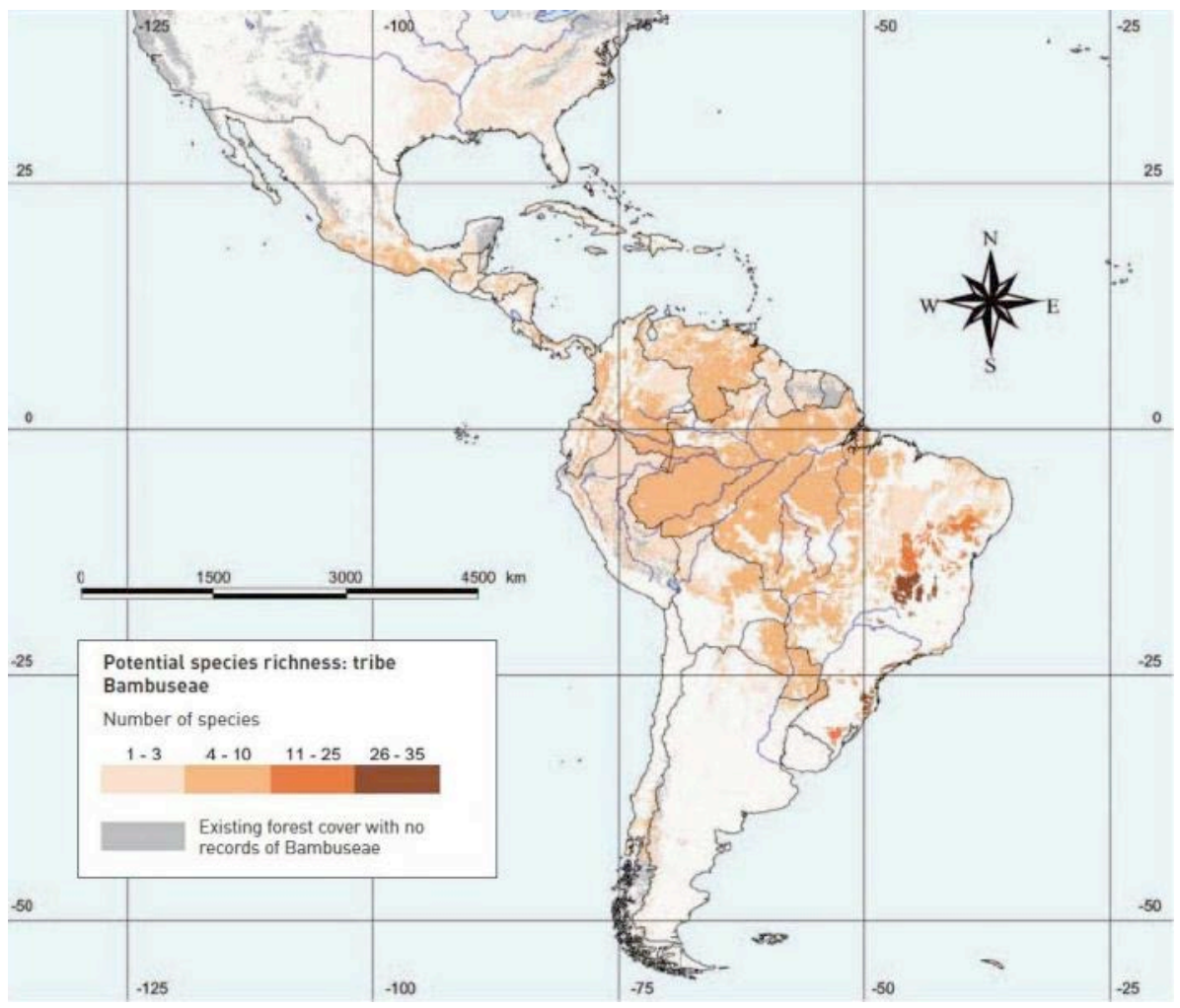

Figura 28 - Mapa da distribuição de espécies de bambu na América.

Fonte: http://www.guaduabamboo.com/

De acordo com Filgueiras e Gonçalves ${ }^{15}$ (apud PEREIRA; BERALDO, 2008), o Brasil possui 34 gêneros e 232 espécies de bambus nativos, sendo 16 gêneros do tipo de bambu herbáceo e 18 gêneros do tipo lenhoso. De acordo com Pereira e Beraldo (2008), a maior parte dos bambus nativos brasileiros é do tipo herbáceo, geralmente enquadrado a um meio específico como o das florestas. A grande maioria das espécies de bambu encontradas no Brasil é exótica, ou seja, não nativas, provindas de países orientais e trazidas ao Brasil em períodos de colonização e imigração oriental. Há, no entanto, espécies nativas americanas como as pertencentes ao gênero Guadua, muito presente em países como Colômbia e Equador, e também presente no Brasil sob a forma de algumas espécies. Estima-se que no Brasil ocorrem $89 \%$ de todos os gêneros e $65 \%$ de todas as espécies de bambu das Américas. Dentre as espécies mais frequentes, destacam-se os principais gêneros exóticos: Bambusa, Dendrocalamus, Gigantochloa, Guadua, Phyllostachys, Sasa e Sinoarundinaria.

\footnotetext{
${ }^{15}$ FILGUEIRAS, T. S.; GONÇALVES, A.P.S. A checklist of the basal grasses and bamboos in Brazil. Bamboo Science and Culture; The Journal of the American Bamboo Society. 18(1): 7-18, (2004).
} 
A rede internacional INBAR (International Network for Bamboo and Rattan), instituição que visa estruturar as bases para o desenvolvimento da cultura, uso e comércio do bambu e junco em nível internacional, recomenda e incentiva a introdução de 19 espécies denominadas prioritárias. Tais espécies são assim definidas de acordo com critérios sobre utilização, cultivo, processamento e produtos, destacando o potencial de cada uma delas, conforme Tabela 2.

Tabela 2 - Espécies prioritárias de bambu de acordo com o INBAR.

Fonte: PEREIRA; BERALDO, 2008

\begin{tabular}{|c|c|c|c|c|c|c|c|c|c|c|c|}
\hline \multirow[t]{2}{*}{ Espécie } & \multicolumn{3}{|c|}{ Valor } & \multirow{2}{*}{ Manejo } & \multicolumn{2}{|c|}{$\begin{array}{l}\text { Clima e } \\
\text { Ecologia }\end{array}$} & \multicolumn{5}{|c|}{$\begin{array}{l}\text { Recursos } \\
\text { Genéticos }\end{array}$} \\
\hline & $C$ & $\mathrm{RI}$ & $E$ & & a & $\mathrm{SI}$ & D & $s$ & IV & $\mathrm{T}$ & $\mathrm{F}$ \\
\hline Bambusa bambos & ++ & ++ & ++ & D & $h, d, s$ & $\mathrm{r}, \mathrm{m}, \mathrm{p}$ & $H$ & $\mathrm{~L}$ & $M$ & M & $H$ \\
\hline B. blumeana* & ++ & ++ & ++ & D & $h, d, s$ & $r, m, p$ & $\mathrm{H}$ & $\mathrm{L}$ & $\mathrm{H}$ & H & $H$ \\
\hline B. polymorpha & + & + & - & D & $h, d$ & $\mathrm{r}, \mathrm{m}$ & $\mathrm{H}$ & $\mathrm{H}$ & M & H & H \\
\hline B. textilis* & + & ++ & + & D & st & $\mathrm{r}, \mathrm{m}$ & M & $\mathrm{L}$ & $\mathrm{H}$ & $\mathrm{H}$ & $\mathrm{L}$ \\
\hline B. tulda* & + & ++ & + & 0 & $h, d$ & $\mathrm{r}, \mathrm{m}$ & $\mathrm{H}$ & $M$ & $\mathrm{H}$ & $\mathrm{H}$ & H \\
\hline B. vulgaris* & - & $\cdot$ & ++ & D & $h, d, s$ & $r, m, p$ & $\mathrm{~L}$ & $\mathrm{~L}$ & $\mathrm{~L}$ & $\mathrm{~L}$ & $\mathrm{~L}$ \\
\hline $\begin{array}{l}\text { Cephalostachyum } \\
\text { pergracile }\end{array}$ & + & ++ & + & W & $h, d$ & $\mathrm{~m}$ & M & $\mathrm{L}$ & M & $\mathrm{H}$ & M \\
\hline Dendrocalamus asper* & ++ & + & ++ & D & $h, d$ & $r$ & $\mathrm{H}$ & $\mathrm{H}$ & $M$ & $\mathrm{H}$ & H \\
\hline D. giganteus* & + & + & + & D & $\mathrm{h}$ & $\mathrm{r}$ & $\mathrm{H}$ & $\mathrm{H}$ & M & $\mathrm{H}$ & H \\
\hline D. latiflorus* & ++ & + & + & D & $\mathrm{h}$ & $\mathrm{r}$ & $M$ & $\mathrm{~L}$ & $M$ & $\mathrm{H}$ & $\mathrm{L}$ \\
\hline D. strictus* & ++ & + & ++ & D & d,s & $m, p$ & $M$ & $\mathrm{~L}$ & $\mathrm{~L}$ & $\mathrm{H}$ & M \\
\hline Gigantochloa apus* & + & ++ & + & D & $\mathrm{h}$ & $r$ & $\mathrm{H}$ & $\mathrm{H}$ & $M$ & $\mathrm{H}$ & H \\
\hline 6. levis* & + & ++ & ++ & $D$ & $\mathrm{~h}$ & $\mathrm{r}$ & $\mathrm{H}$ & $\mathrm{L}$ & $\mathrm{H}$ & $\mathrm{H}$ & H \\
\hline G. pseudoarundinaria & ++ & + & + & $D$ & $h, d$ & $\mathrm{r}$ & $M$ & $\mathrm{~L}$ & $\mathrm{H}$ & $\mathrm{H}$ & L \\
\hline Guadua angustifolia* & ++ & ++ & ++ & $W$ & $\mathrm{~h}$ & $\mathrm{r}, \mathrm{m}$ & $\mathrm{H}$ & $\mathrm{H}$ & $\mathrm{H}$ & $\mathrm{H}$ & $\mathrm{H}$ \\
\hline Melocanna baccifera* & + & ++ & + & W & $\mathrm{h}$ & $r$ & $\mathrm{H}$ & $M$ & $\mathrm{H}$ & $\mathrm{H}$ & M \\
\hline Ochilandra & + & + & + & $W$ & $\mathrm{~h}$ & $r$ & $\mathrm{H}$ & $\mathrm{H}$ & $M$ & $\mathrm{H}$ & H \\
\hline $\begin{array}{l}\text { Phyllostachys } \\
\text { pubescens* }\end{array}$ & ++ & ++ & ++ & D & $t$ & $\mathrm{r}, \mathrm{m}$ & M & M & L & $\mathrm{L}$ & L \\
\hline $\begin{array}{l}\text { Thyrsostachys } \\
\text { siamensis* }\end{array}$ & ++ & ++ & ++ & $D$ & $d,(h)$ & $w .(r)$ & M & M & L & $\mathrm{H}$ & L \\
\hline
\end{tabular}

"Espécies existentes no Brasil (IAC, UNESP e em coleções particulares).

$$
\begin{aligned}
& \text { Valor: } C=\text { Potencial para comercializaçâo } \quad++ \text { (alto); } \quad+\text { (médio); } \quad \text {-(baixo) } \\
& \mathrm{RI}=\text { Indústria rural } \quad++ \text { (alto); }+ \text { (médio); }- \text {-(baixo) } \\
& \mathrm{E}=\text { Regenerador ambiental } \quad++ \text { (alto); } \quad+\text { (médio); } \quad \text {-(baixo) } \\
& \text { Manejo: } \quad D=\text { Domesticado } \\
& \text { Clima e Ecologia: } \quad \text { l }=\text { Clima: } \quad h \text { (trópicos úmidos); } d \text { (trópicos secos); } \\
& \text { st (subtropical); } s \text { (semi-árido); } t \text { (temperado) } \\
& \mathrm{SI}=\text { Solos: } \mathrm{r}(\text { rico); } \mathrm{m} \text { (médio); } \mathrm{p} \text { (pobre) } \\
& \text { Recursos genéticos: } \quad D=\text { Desgaste genético } \\
& S=\text { Necessidade de pesquisa sobre armazenamento de sementes } \\
& \text { IV = Necessidade de pesquisa sobre reproduçâa in vitro } \\
& T=\text { Necessidade de maiores transferências } \\
& F=\text { Necessidade de levantamentos futuros } \\
& H \text { (alto) - } M \text { (médio) - L (baixo) }
\end{aligned}
$$


As características das espécies somadas aos graus de flexibilidade e resistência que os bambus vão adquirindo nas suas etapas de desenvolvimento determinam o uso ao qual o bambu será destinado.

\subsection{3 - Características Gerais}

\subsubsection{1 - Características físicas e mecânicas}

O bambu é definido como gramínea arborescente, uma planta lenhosa, monocotiledônea e angiosperma. Ao analisar um colmo de bambu imagina-se que seu sistema de raízes seja tipicamente unificado, como o de uma árvore convencional. No entanto, o crescimento do bambu define-se pela propagação de seus rizomas, característica primária na identificação do gênero, divididos em duas categorias: os leptomorfos (alastrantes ou monopodiais) e os paquimorfos (entouceirantes ou simpodiais).

$\mathrm{Na}$ categoria leptomorfo (monopodial ou alastrante), o crescimento ocorre por uma única gema apical, que persiste por toda a vida da planta. É o caso das palmeiras (Arecaceae) e da maioria dos bambus usados artesanalmente no Japão. A cada ano, os rizomas dessa categoria, popularmente conhecidas como "bambus corredores" lançam no solo suas gemas apicais, e frequentemente a nova planta emergirá muito além da planta "mãe". Assim, o perímetro ocupado pela plantação tende a ser cada vez maior, e a se expandir rapidamente. Os bambus monopodiais tendem a crescer mais comumente em regiões de clima temperado.

Já na categoria paquimorfos (simpodial ou entouceirante), várias gemas participam consecutivamente da formação de cada eixo, seja porque a gema apical perdeu a dominância ou deixou de ser ativa. Assim sendo, os bambuzais desse sistema tendem a ser muito mais densos devido ao crescimento de seu rizoma próximo à planta "mãe". Por se desenvolverem muito nas regiões tropicais, são conhecidos como "bambus tropicais", sendo estes os principais bambus encontrados no Brasil.

A parte da planta que se desenvolve acima da superfície da terra, denomina-se o colmo do bambu, que é composto por um perfil tubular cilíndrico interrompido por sucessivos diafragmas caracterizando os nós, que garantem resistência mecânica ao colmo. Os colmos podem possuir diferentes alturas e diâmetros dependendo da espécie, mas sempre nascem com o diâmetro que irá manter em toda sua vida. Adquire seu crescimento máximo em menos de um ano após sua brotação e com o término do período de crescimento inicia-se o período de maturação ou sazonamento, que alcança seu grau mais elevado entre 3 e 6 anos. Segundo Pereira e Beraldo (2008), o design do colmo de bambu 
pode ser considerado uma das obras-primas da natureza por aliar leveza, flexibilidade e resistência mecânica.

Quanto à anatomia geral dos colmos, pode-se afirmar que o bambu é composto por córtex, parênquima, fibras e sistema vascular. A forma, tamanho, número e concentração vascular variam desde a periferia até a parte interna do colmo e desde a base do colmo até o ápice do mesmo. Suas células estão orientadas paralelas ao eixo de crescimento do colmo, sendo a parte externa do colmo composta por camadas de células epidermais cobertas por uma camada de cera. Na parede do colmo a parte externa é caracterizada pelo predomínio de feixes de fibras, enquanto a parte interna pelo predomínio do tecido parenquimático.
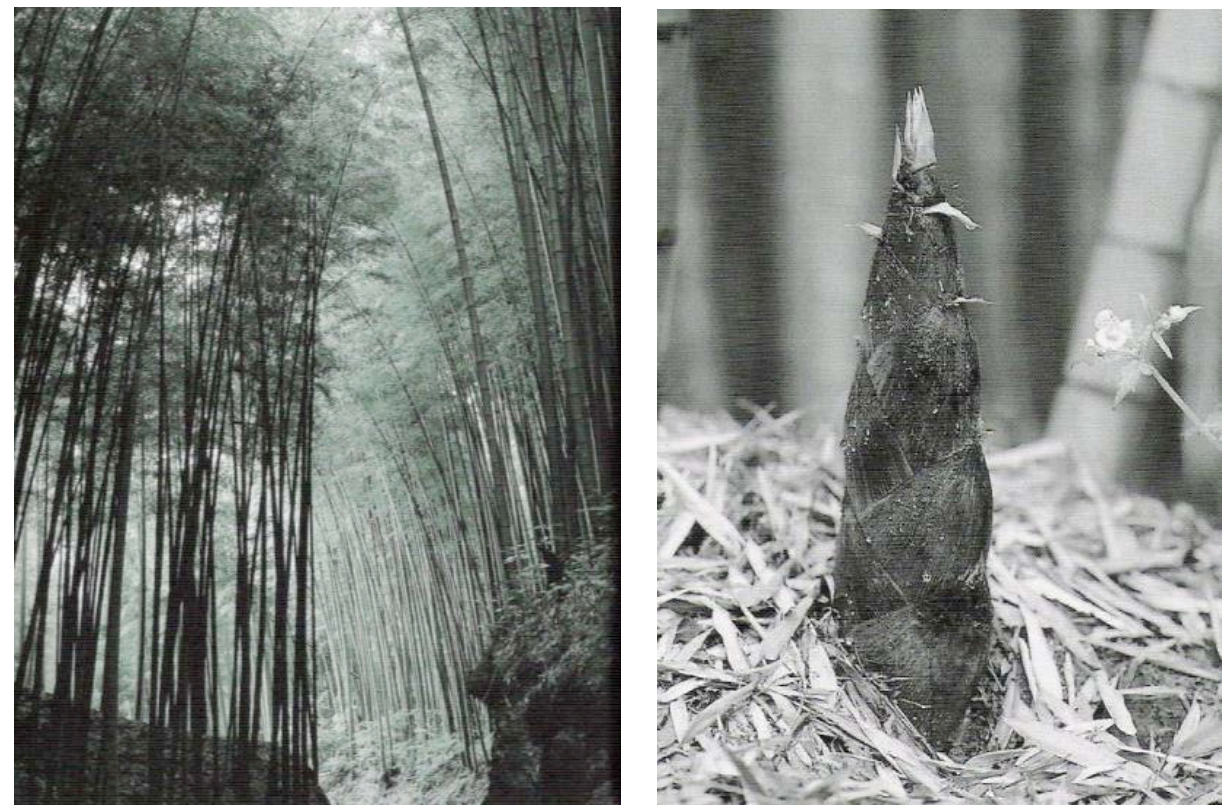

Figuras 29 e 30 - Floresta tropical adulta e broto de bambu.

Fonte: VILLEGAS, 2003 (29) e BESS, 2001 (30).

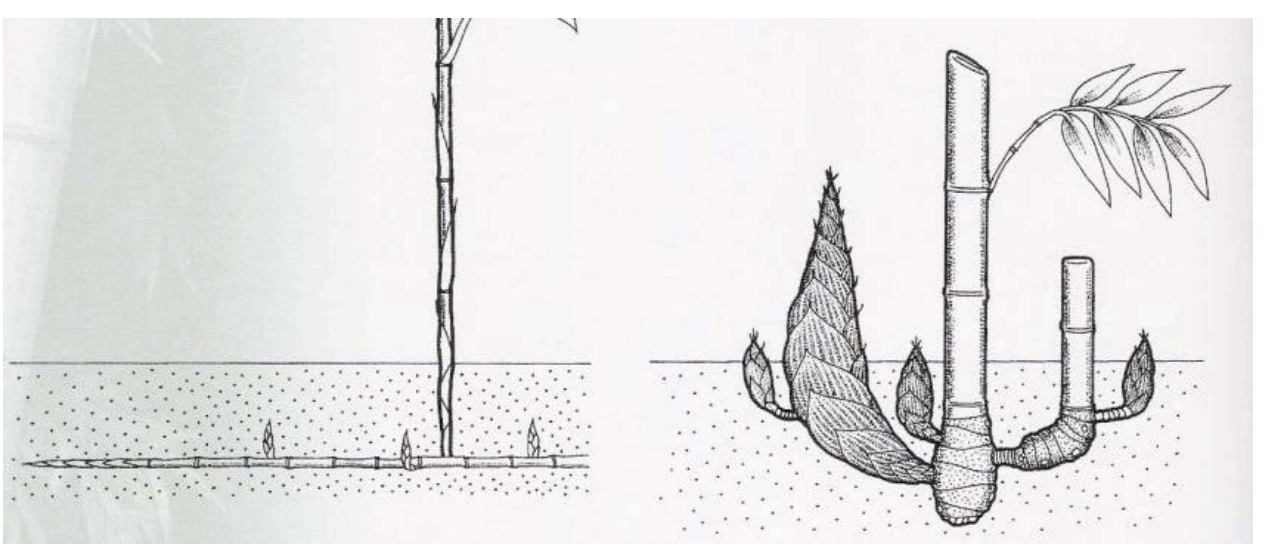

Figuras 31 e 32 - Sistemas leptomorfos e paquimorfos respectivamente.

Fonte: BESS, 2001. 
Quimicamente, o bambu é composto em sua maior parte em carboidratos, como celulose e lignina, sendo que a proporção de tais componentes varia ao longo do período de maturação do colmo, permanecendo estável após o período de um ano. O amido armazenado em seu tecido parenquimático é uma característica marcante do bambu, e seu teor varia de acordo com a estação do ano de espécie para espécie. Este fato é importante na determinação do período de colheita do bambu visando sua preservação frente às ameaças biológicas. Também sobre a colheita de colmos contendo o menor teor de amido possível, há a crença de relacionar o período com o calendário lunar. Janssen (1995) conclui que não há relação entre o corte baseado no calendário lunar e o ataque de insetos xilófagos; no entanto, afirma que não há nenhum impedimento técnico para exercer a prática de tal crença local, quando for o caso.

Quanto às características físicas e mecânicas, o bambu apresenta sua máxima resistência a partir dos três anos do plantio aproximadamente. Suas características físicas como estrutura tubular de fibras longitudinais e baixa densidade conferem à planta uma grande leveza, flexibilidade e resistência, principalmente à tração.

Segundo Hidalgo-López (2003), pode-se avaliar a resistência do colmo de bambu sob a perspectiva longitudinal e transversal. Na perspectiva longitudinal, em relação às três diferentes partes: colmo inteiro, entrenó e parede do colmo. No colmo inteiro, pode-se fazer uma análise comparativa entre as três partes do colmo inteiro: base, meio e topo. Na maior parte dos casos, a parte superior do colmo é a mais resistente em termos de esforço de compressão e de flexão. Quanto ao entrenó, as fibras tendem a se tornar menores na medida em que se aproximam do nó, sendo assim a parte mais resistente a central do entrenó. Já em relação à parede do colmo, a resistência aumenta quanto mais exterior for a camada do bambu, conforme Figura 33.

Fatores como o teor de umidade, a idade e a massa específica do colmo também são muito influentes na determinação das propriedades mecânicas do bambu. A variação da umidade pode ser responsável por variações dimensionais indesejadas durante a etapa de secagem do colmo. A idade do colmo influencia muito a resistência mecânica uma vez que somente depois de atingido o estado de maturação máximo que o bambu deveria ser avaliado por meio de ensaios. Janssen (1995) afirma que a mais importante propriedade mecânica do bambu é sua massa específica aparente pela unidade de volume, sua densidade em $\mathrm{kg} / \mathrm{m} 3$, que se situa entre $700 \mathrm{~kg} / \mathrm{m} 3$ e $800 \mathrm{~kg} / \mathrm{m} 3$. O autor demonstrou que o bambu, na relação resistência e dureza com relação à massa específica, possui valores inferiores somente aos do aço, conforme Figura 34. 
(a) LONGITUDINAL SECTION
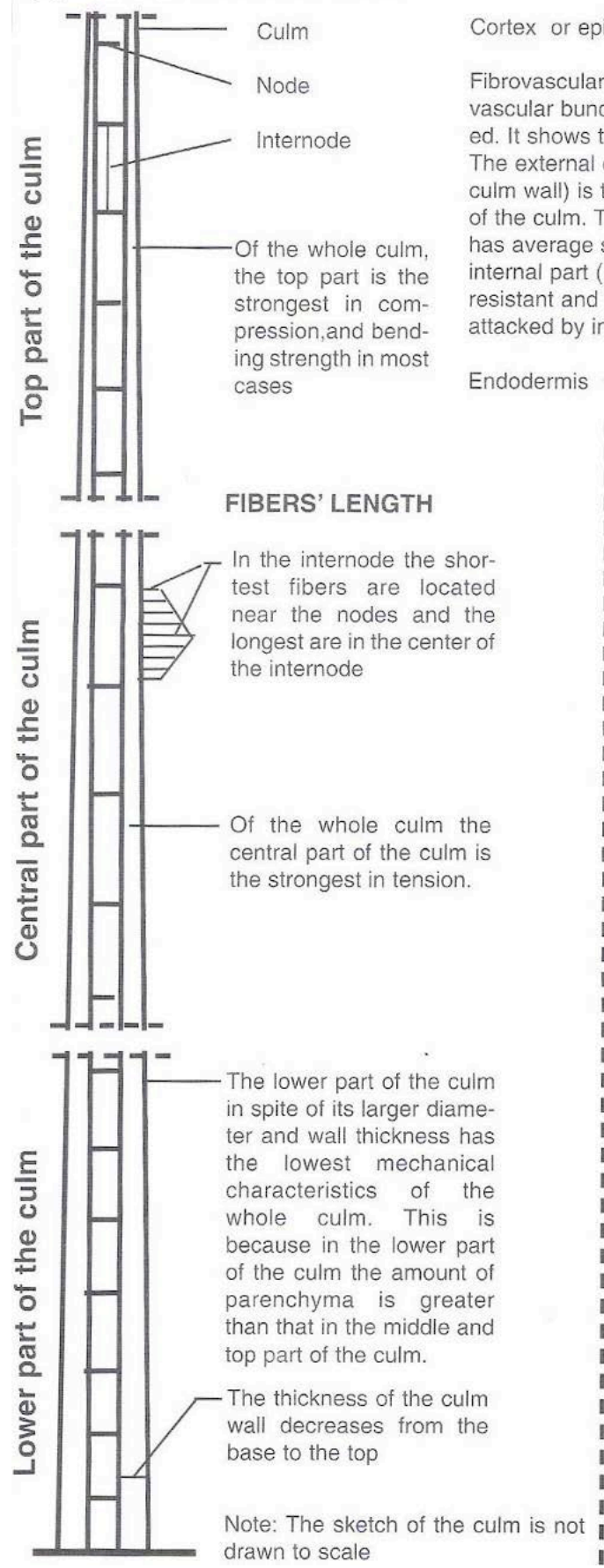

(b) TRANSVERSAL SECTION OF CULM

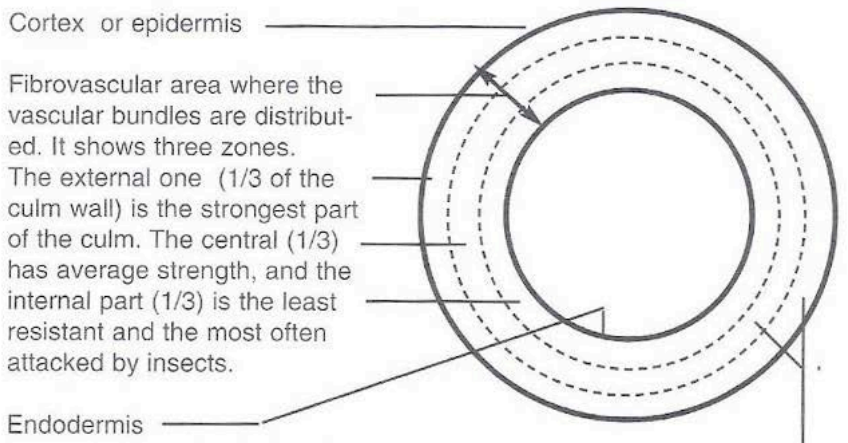

C. TENSILE STRENGTH OF A VASCULAR BUNDLE

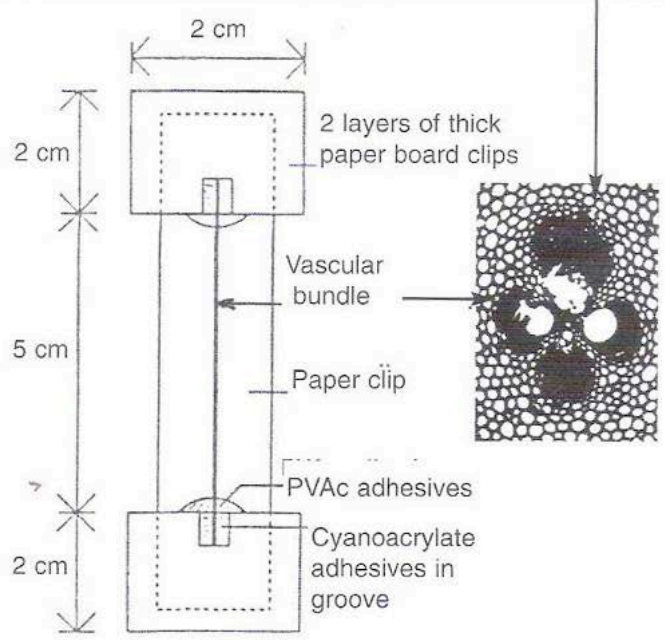

$\mathrm{kg} / \mathrm{cm}^{2}$

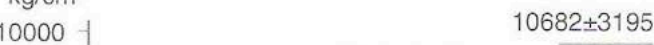

$9000-\quad 9450 \pm 3090$

9000

8000

7000

6000

5000

4000

3000

2000

1000

0

inner

D. Tensil strength of vascular bundles from outer, mid dle and inner portion of $P$. pubescens (AfterYeh, 1995)

Figura 33 - Estrutura do bambu transversal e longitudinalmente.

Fonte: HIDALGO-LÓPEZ, 2003. 


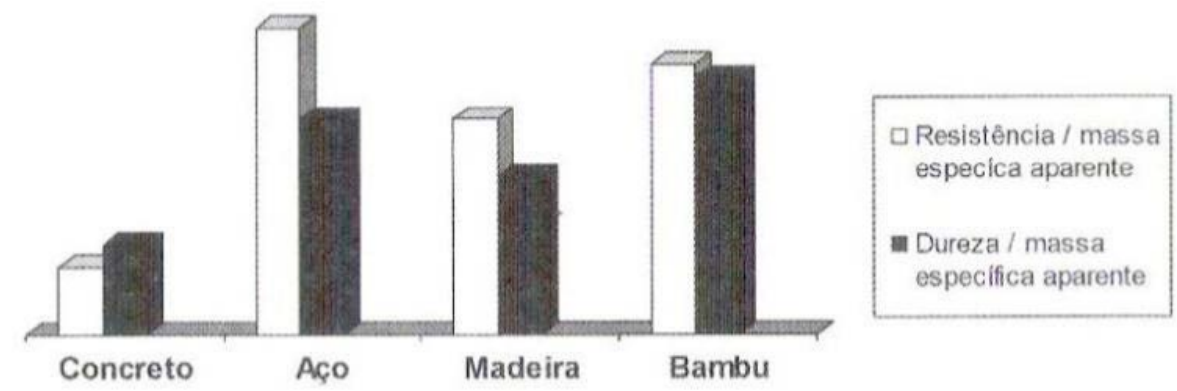

Figura 34 - Gráfico de relação entre resistência e dureza e massa específica.

Fonte: JANSSEN, 1995.

Tabela 3 - Propriedades do bambu, aço e concreto, valores médios.

Fonte: MORADO, 1994.

\begin{tabular}{|l|c|c|c|c|}
\hline & $\begin{array}{c}\text { Massa } \\
\text { específica } \\
\left(\mathrm{g} / \mathrm{cm}^{3}\right)\end{array}$ & $\begin{array}{c}\text { Módulo elast. } \\
\left(\mathrm{kN} / \mathrm{m} \mathrm{m}^{2}\right)\end{array}$ & $\begin{array}{c}\text { Compressão } \\
\left(\mathrm{n} / \mathrm{mm}^{2}\right)\end{array}$ & $\begin{array}{c}\text { Tração } \\
\left(\mathrm{n} / \mathrm{mm}^{2}\right)\end{array}$ \\
\hline AÇO & 7,8 & 210 & $250-1.800$ & $250-1.800$ \\
\hline CONCRETO & 2,4 & $10-30$ & $10-100$ & $1-10$ \\
\hline BAMBU & $0,8-1,4$ & $7-20$ & $38-65$ & $180-440$ \\
\hline
\end{tabular}

Segundo Pereira e Beraldo (2008), ensaios de compressão do bambu realizados no Brasil mostraram uma variabilidade muito grande de resultados, devido à dificuldade de precisão dos ensaios. Em bambus de maior diâmetro, em geral retira-se uma seção retangular de sua parede para a realização dos ensaios. A determinação do módulo de elasticidade à compressão também apresenta certas dificuldades, pois a deformação do corpo de prova é variável ao longo da seção. A parte externa, por ter mais rigidez, apresenta menor deformação do que a camada interna. Segundo Hidalgo-López (1974), a resistência média dos corpos-de-prova cilíndricos (colmo íntegro) é sempre superior àquela obtida em corpos de prova usinados.

Já em relação à tração paralela, o bambu apresenta elevada resistência, da ordem de até $370 \mathrm{MPa}$, sendo por isso muitas vezes proposto em substituição ao aço. Nos ensaios de flexão, alguns fatores tais como a geometria do colmo, a posição e a frequência dos diafragmas são de grande influência na conformação dos resultados (Figuras 36, 37 e 38). 

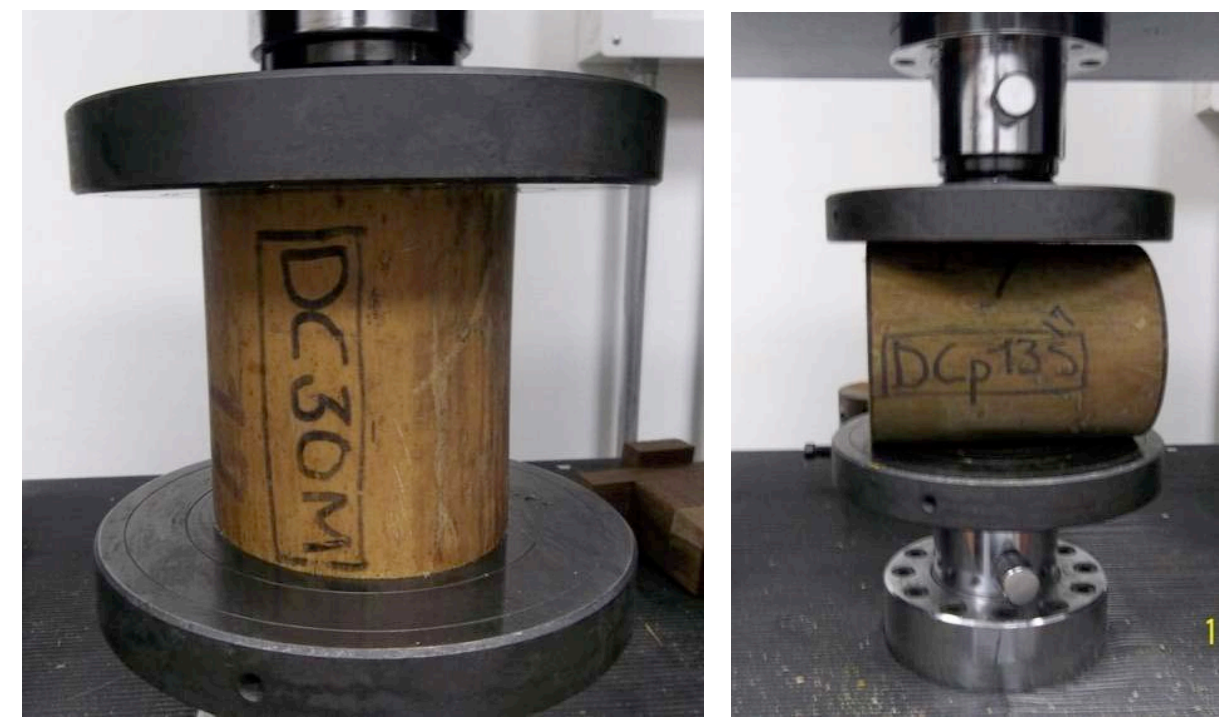

Figuras 35 e 36 - Ensaios de compressão (parelela e transversal às fibras) no Centro de Investigación de Madera y Guadua, Universidad Nacional de Colombia.

Fonte: Acervo da autora.

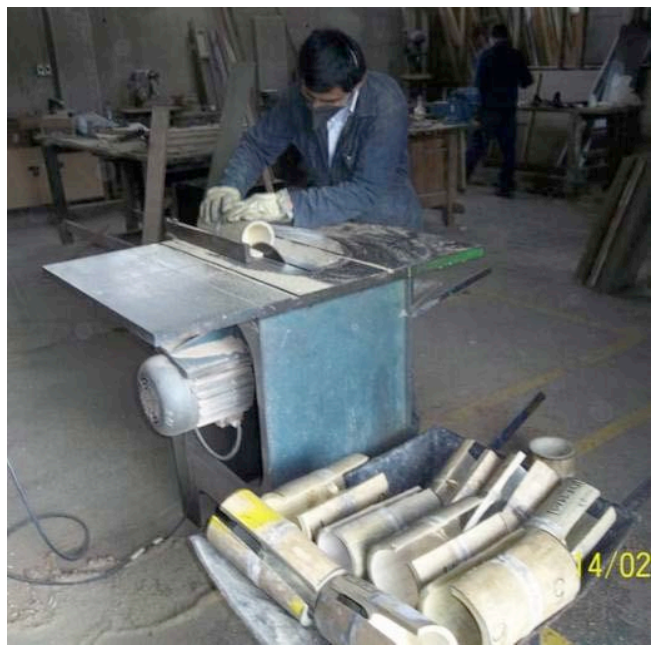

Figura 37- Usinagem de corpos de prova para ensaios de tração no Centro de Investigación de Madera y Guadua, Universidad Nacional de Colombia. Fonte: Acervo da autora. 


\subsubsection{2 - Cultivo}

O cultivo do bambu depende diretamente dos fatores climáticos existentes no local. Embora haja muitas espécies pertencentes às regiões temperadas, a grande maioria dos bambus desenvolve-se em zonas tropical, caracterizadas por:

- Áreas quentes, com um clima entre $8^{\circ} \mathrm{C}$ e $36^{\circ} \mathrm{C}$;

- Áreas com chuvas abundantes, segundo Deogun ${ }^{16}$ (apud OLIVEIRA, 1980), com médias de precipitações anuais mínimas de $762 \mathrm{~mm}$;

- Áreas com alta umidade relativa, de $80 \%$ ou mais;

- Solos mais sedimentares, com pH entre 5,0 e 6,5.

Estando garantidas tais condições, o bambu desenvolve-se com facilidade, sendo a adubação um item que pode melhorar o desempenho da plantação, mesmo não sendo de suma importância para seu desenvolvimento.

A plantação do bambu pode ser feita por sementes ou por propagação vegetativa. A primeira é uma técnica pouco utilizada uma vez que depende do florescimento da planta, que raramente ocorre, demorando até 120 anos para algumas espécies. A propagação vegetativa por fracionamento é, segundo a maioria dos autores, a mais recomendada opção para o plantio de bambu. Tal fracionamento pode ocorrer na forma de:

- transplante total (desmembramento de touceiras);

- transplante parcial (seção de um colmo, recomendado para pequenos plantios);

- pedaços de rizoma (pedaços do rizoma com raízes, mais indicado para espécies alastrantes);

- pedaços de colmos (segmentos do colmo contendo gemas primárias, mais indicado para espécies entouceirantes, conforme Figura 38);

- por ramos laterais (mais utilizados para o manejo, conforme figuras 38 e 39).

\footnotetext{
${ }^{16}$ DEOGUN, P. N. The silviculture and management of the bamboo Dendrocalamus strictus Nees. Indian Forest Records, Dehra Dun, 2(4), 1936.
} 

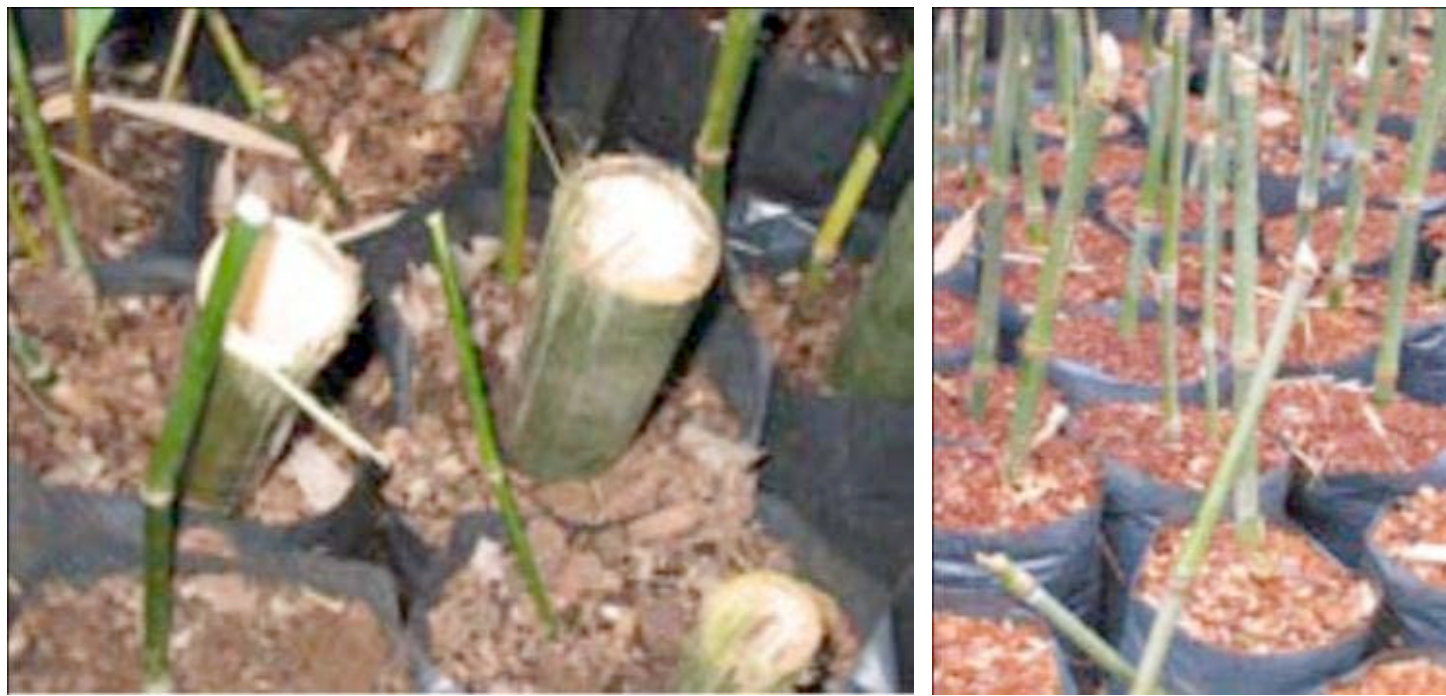

Figuras 38 e 39 - Propagação por pedaços de colmo e propagação por ramos laterais.

Fonte: PEREIRA; BERALDO, 2008.

\subsubsection{3 - Colheita}

A colheita do bambu deve ser realizada, de preferência, no momento em que o nível de açúcares contido na planta seja mais reduzido. Uma ferramenta semelhante ao machado é utilizada, e ao menos três golpes são necessários para a colheita dos exemplares já adultos. Um corte é feito próximo ao nível do solo, logo acima do nó para evitar a formação de uma cavidade natural na planta que acumule água e apodreça seu rizoma. O bambu colhido pode ser deixado no bosque, evitando sempre que possível o contato com o solo para que não ocorra a proliferação de insetos. Tal técnica é muito difundida na Colômbia.

$O$ ataque de insetos, a variação de temperatura e a umidade são os principais agentes da degradação do bambu. Para uma adequada conservação do material os principais cuidados a serem tomados são:

- o corte do colmo;

- a secagem;

- tratamento contra fungos e insetos. 


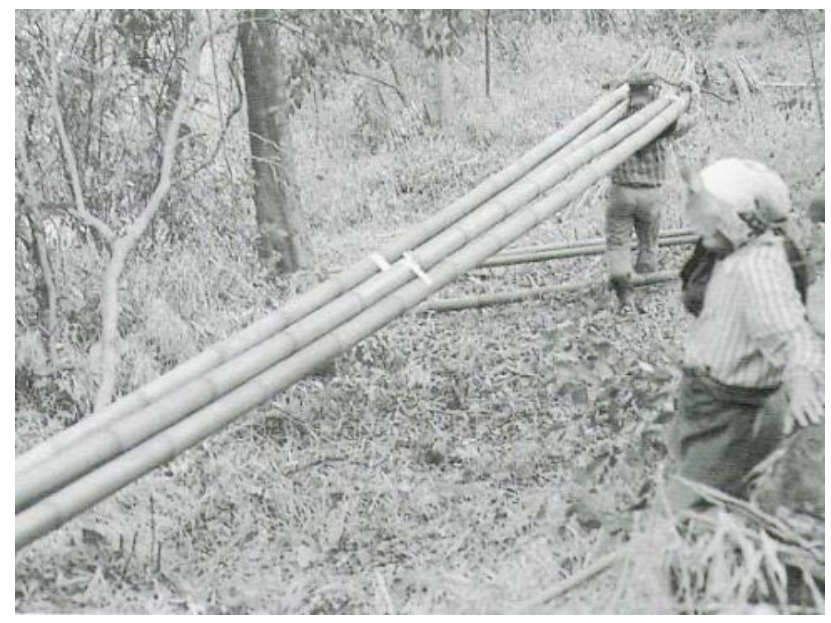

Figura 40 - Colheita de bambu.

Fonte : BESS, 2001.

\subsubsection{4 - Tratamento}

Tratamentos físicos e químicos devem ser pensados para o material uma vez que sua durabilidade natural e resistência aos insetos são limitadas. Após o corte do colmo, já deve ter sido determinado a qual tipo de tratamento ele será submetido. Os métodos mais comumente empregados dividem-se em dois grupos: os naturais e os químicos.

Os métodos naturais consistem em práticas nas quais não se submetem os colmos a nenhum processo químico. Muitos desses processos são utilizados tradicionalmente, sob a condição de efetuar a colheita de colmos maduros somente nos períodos de menor pluviosidade para garantir a maior vida útil possível ao material. Certamente são métodos que apresentam menos eficiência do que os métodos químicos. Segundo Pereira e Beraldo (2008), dentre eles podem-se citar:

- Cura na mata (ou "avinagrado"): após o corte, mantem-se os colmos na posição vertical durante 4 a 8 semanas, sem remover as folhas, afastando-os do solo. 0 processo de assimilação da seiva continua ocorrendo até a queda das folhas, o que garante a redução de amido no colmo.

- Cura por imersão em água: logo após o corte, submergem-se os colmos em água. O tempo de tratamento pode variar de 4 a 8 semanas, podendo ser realizado em água parada ou corrente. Deve-se tomar cuidado com a apresentação de manchas e rachaduras nos colmos com o passar do tempo de submersão. Deve-se atentar para a 
necessidade de substituição de água, devido à geração de odor desagradável e à possível presença de larvas de insetos, sobretudo mosquitos.

- Cura pela ação do fogo: submete-se o colmo à ação do fogo direto, eliminando a seiva por exsudação. O contato com a parede externa do bambu libera uma cera natural, garantindo coloração e brilho. Esse método é muito empregado na confecção de mobiliário em bambu (cana-da-índia, gênero Phyllostachys)

- Cura pela ação da fumaça (ou defumação): por alterar quimicamente o amido existente no colmo, sua vida útil é aumentada. O método apresenta maior eficiência se comparado aos dois outros métodos, mas representa risco de rachaduras devido à temperatura que pode atingir até $150^{\circ} \mathrm{C}$.

Dentre os métodos químicos, considerados mais eficientes, podem-se citar:

- Imersão em produtos oleosos: eficiente contra o ataque de organismos xilófagos, esse é o tratamento indicado para peças com função estrutural. Trata-se de um banho quente a $90{ }^{\circ} \mathrm{C}$ em creosoto, seguido de um banho frio com o mesmo produto. Após o tratamento, armazena-se o material para eliminar o excesso do produto.

- Imersão em produtos oleossolúveis: submergem-se os colmos em uma solução óleosolúvel por 7 dias à temperatura ambiente.

- Imersão em produtos hidrossolúveis: trata-se de um tratamento que diversos sais são associados à lignina e à celulose, formando um composto insolúvel tóxico aos insetos. Dentre os sais, os mais usados são o borato de cobre cromatado (CCB) e a mistura de ácido bórico e bórax. A imersão deve durar de duas a quatro semanas, em temperatura ambiente.

- Substituição de seiva por sais hidrossolúveis através da transpiração: processo eficiente para colmos que não sejam tão extensos (até 3 metros). Colocam-se as bases dos colmos em tambores com a mesma solução anterior a qual vai sendo sugada à medida em que a água da seiva do colmo evapora. O processo dura aproximadamente 7 dias. 
- Boucherie: substituição acelerada de seiva, na qual os colmos recém-cortados são conectados a um equipamento que impulsiona com o auxílio de uma bomba uma solução para o tratamento químico do bambu. Necessita de sistematização da etapa dos engates dos bambus, já que esta leva maior tempo e pode prejudicar a produtividade do processo.

- Autoclave: similar ao processo da madeira, no entanto os diafragmas do bambu devem ser rompidos para não ocorrer a explosão do colmo no processo de vácuo. Trata-se do tratamento mais ambientalmente agressivo devido às substâncias químicas envolvidas, motivo pelo qual é de extrema importância que seja realizado em empresas apropriadas para tal fim.
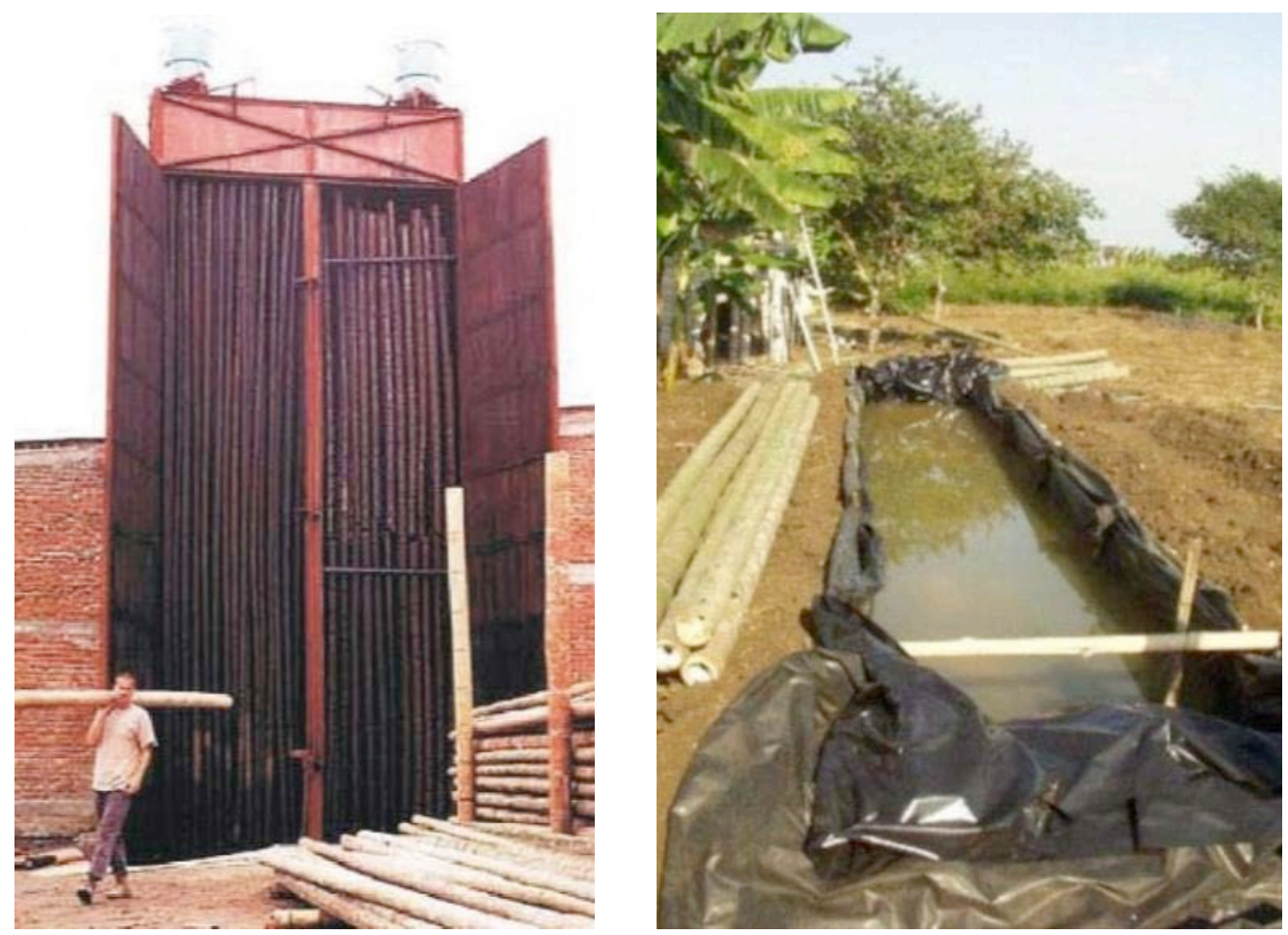

Figuras 41 e 42 - Tratamentos de cura pela ação da fumaça e por imersão em água.

Fonte: DETHIER; STEFFENS, 2000.

No entanto, deve-se considerar que, o principal item de influência na durabilidade do material é a elaboração de um projeto adequado. O desenho do projeto definirá a locação e função das peças e determinará o desempenho que o material apresentará e a manutenção à qual o edifício/objeto estará sujeito. Proteção contra as chuvas, intempéries e umidade do 
solo são algumas das premissas primordiais para o projetista de bambu. De uma forma geral, é fundamental o conhecimento pleno das características gerais dos materiais para usufruir de uma correta utilização do potencial construtivo de cada material.

\subsection{4 - O Bambu e a Construção civil}
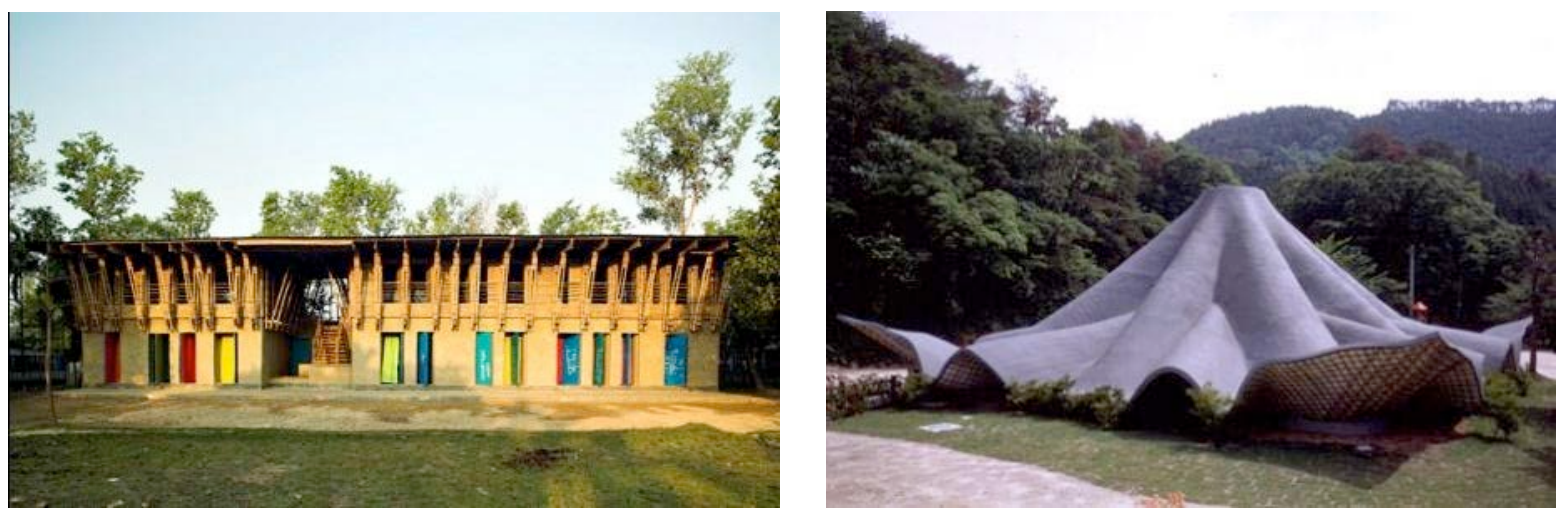

Figuras 43 e 44 - Exemplos da produção da arquitetura contemporânea oriental em bambu: Escola Em Bangladesh (Anna Heringer e Eike Roswag) e Centro Residencial no Japão (Shoei Yoh).

Fonte: http://www.anna-heringer.com/(43) e DETHIER; STEFFENS, 2000 (44).
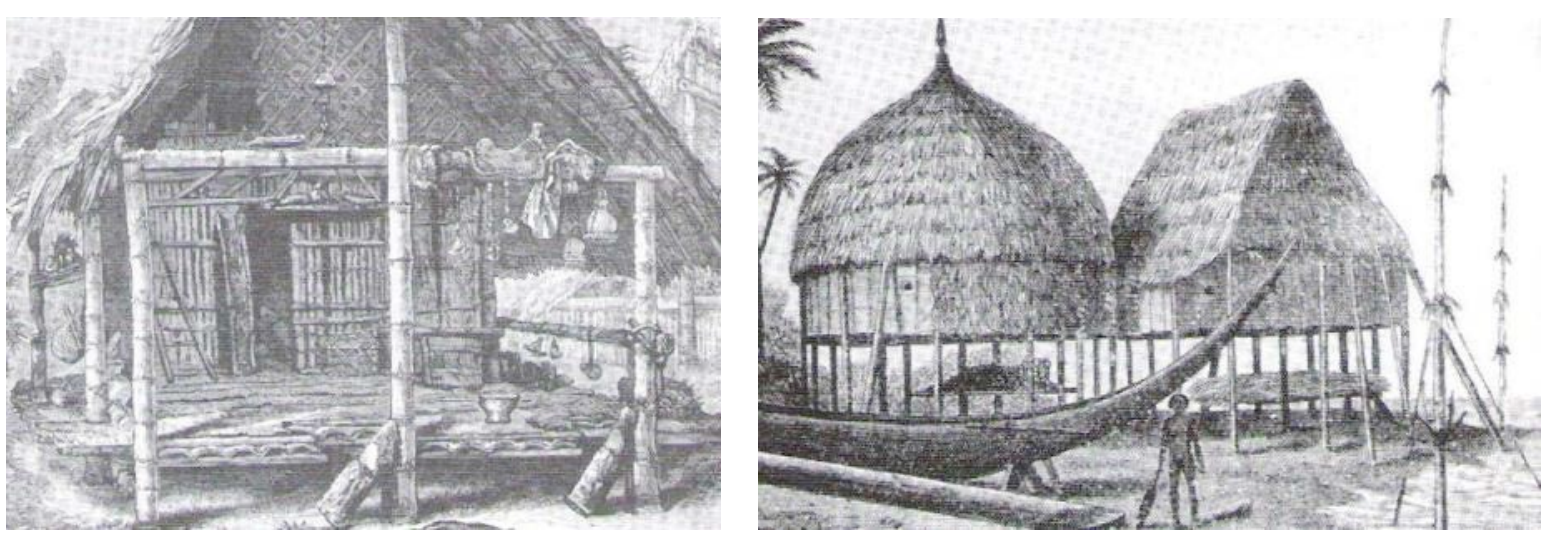

Figuras 45 e 46 - Habitação temporária indígena na Colômbia e habitação em bambu e madeira no Equador.

Fonte: HIDALGO-LÓPEZ, 2003.

A grande capacidade produtiva do bambu somada à sua facilidade de plantio, produção, corte, transporte e manuseio faz com que o bambu seja um material de inserção abrangente na construção do espaço físico. O uso milenar e o caráter popular da planta faz com que esteja presente em grande parte das culturas construtivas do mundo, sobretudo nos países orientais como Indonésia, Índia, China e Japão, onde até hoje pode-se encontrar o bambu aplicado às construções civis. 
No continente americano, o relato mais preciso sobre a existência do bambu data do período do descobrimento, onde escritores espanhóis do período descrevem a presença de imensas florestas de bambus gigantes. A maioria dessas florestas estava então distribuída ao longo do sul do México, América Central, América do Sul e norte da Argentina. Os relatos apontam a existência de povoados desenvolvidos internamente à essas florestas, explorando o uso do bambu em toda sua vastidão, inclusive plantado, como mecanismo de defesa. O conjunto de descrições indica as regiões da América Central, Colômbia e Equador como as regiões onde a cultura do bambu na construção civil mais se manifestou na América (Figuras 47, 48, 49 e 50).


Figuras 47, 48, 49 e 50 - Exemplos da produção da arquitetura contemporânea colombiana em bambu: Auditório Granja de Mama Lulu (Hernando Hincapie), Catedral de Pereira (Simón Vélez), Casa del Pueblo (Simón Hosie), e Ponte (Joerg STAMN).

Fontes: Acervo da autora (47), acervo pessoal Simón Vélez (48), http://www.colarte.com/ (49) e http://www.ecobamboo.net/(50).

Naturalmente, o desenvolvimento de tecnologias construtivas usando o bambu como matéria-prima ao longo de todos esses anos fez de tais povos os melhores construtores de bambu nas Américas. A Colômbia é referência em pesquisa em tecnologia 
do bambu, conforme exemplificado nas diversas construções contemporâneas, e que será melhor desenvolvido em item adiante.

No Brasil, a produção da construção civil em bambu ainda é incipiente. E por não haver no país uma forte cultura de construção em bambu (com exceção de algumas regiões que receberam imigração japonesa), seu uso ainda se resume, em grande parte, a pequenas construções auxiliares rurais, de baixa tecnologia, comprometendo assim a imagem de durabilidade do material e gerando forte preconceito contra a utilização do mesmo. Há, no entanto, um movimento crescente por parte de arquitetos, engenheiros, agrônomos e biólogos em torno da prática da chamada bio-construção, onde o bambu entra como uma das principais matérias-primas de tal prática. Todavia, ainda há um longo caminho a ser percorrido até a consolidação do material no país.

Algumas obras em bambu de caráter de vanguarda foram desenvolvidas recentemente no país, como o Centro Cultural Max Feffer, em Pardinho, SP (Arquiteta Leiko Motomura), o Restaurante do Hotel do Frade em Angra dos Reis, RJ (Arquiteto Simón Vélez) e o Memorial dos Índios em Campo Grande, MS (Arquitetos Edson Sartori, Rubens Cardoso e David Rees Dias). Com o passar dos anos também se formaram crescentes associações, grupos e comunidades que visam à discussão, ao ensino e à divulgação do bambu enquanto prática construtiva, como por exemplo, a EBIOBAMBU (Escola de Bio-arquitetura e Centro de Pesquisa e Tecnologia Experimental em Bambu), o TIBÁ (Tecnologia Intuitiva e Bioarquitetura), e as comunidades "Bambu Brasil", "Rede Social do Bambu", "Rede Brasileira do Bambu", entre outras.
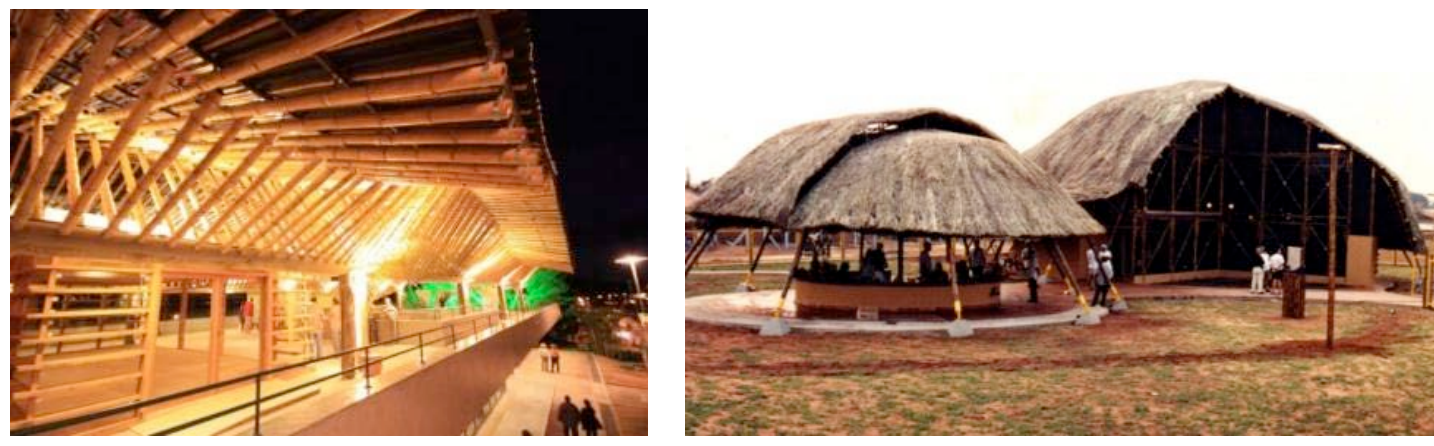

Figuras 51 e 52 - Exemplos da produção da arquitetura contemporânea brasileira em bambu: Centro Cultural Max Feffer e Memorial dos Índios.

Fontes: http://www.amima-arquitetura.com/(51) e PEREIRA; BERALDO, 2008 (52). 
Além disso, importantes centros de pesquisa, ensino e extensão no Brasil prosseguem em pesquisas de desenvolvimento tecnológico sobre o tema. Podem-se citar com mais ênfase:

- Departamento de Engenharia Civil da PUC - RJ;

- Departamento de Engenharia Mecânica da UNESP - SP;

- Faculdade de Engenharia Agrícola da UNICAMP - SP;

- Instituto Agronômico de Campinas - SP;

- Escola de Engenharia Civil da UFMG - MG;

- Instituto do Bambu da UFAL - AL;

- Universidade Federal da Paraíba UFPB - PB;

- Universidade Federal de Santa Catarina UFSC - SC;

- Universidade de Brasília UnB - DF;

- Centro de Energia Nuclear na Agricultura CENA USP, Piracicaba - SP;

- Escola Superior de Agricultura "Luiz de Queiroz" ESALQ USP, Piracicaba - SP.

Já em relação às espécies mais adequadas para o uso associado à construção civil, e dentre as espécies prioritárias de bambu recomendadas pelo INBAR, podem-se citar:

- Bambusa bambos;

- Bambusa blumeana;

- Bambusa polymorpha;

- Bambusa tulda;

- Bambusa vulgaris;

- Dendrocalamus asper;

- Dendrocalamus giganteus;

- Dendrocalamus latiflorus;

- Dendrocalamus strictus;

- Gigantochloa apus; 
- Gigantochloa levis;

- Melocanna baccifera;

- Phyllostachys pubescens;

- Guadua angustifolia.

Em relação às espécies citadas, a Guadua angustifolia sobressai-se por suas excelentes propriedades estruturais. Espécie nativa na Colômbia e muito usada em suas construções, a Guadua possui capacidade para absorver energia e admitir uma maior flexão, fazendo deste o material ideal para construções sismo resistentes. Seu uso estrutural também pode ser associado às construções monumentais como o pavilhão projetado e construído por Simón Vélez para a Feira de Hannover de 2000, na Alemanha, onde o material foi apresentado ao mundo, contemplando adequadamente os requisitos de baixo custo, estética, segurança e rapidez.

Segundo Villegas (2003), dentro de um universo onde a espécie se desenvolve naturalmente, o custo para a construção com Guadua representa valores até $45 \%$ inferiores aos da construção convencional, contemplando assim uma interessante alternativa aos sérios problemas do déficit habitacional que afetam a maioria dos países da América Latina.
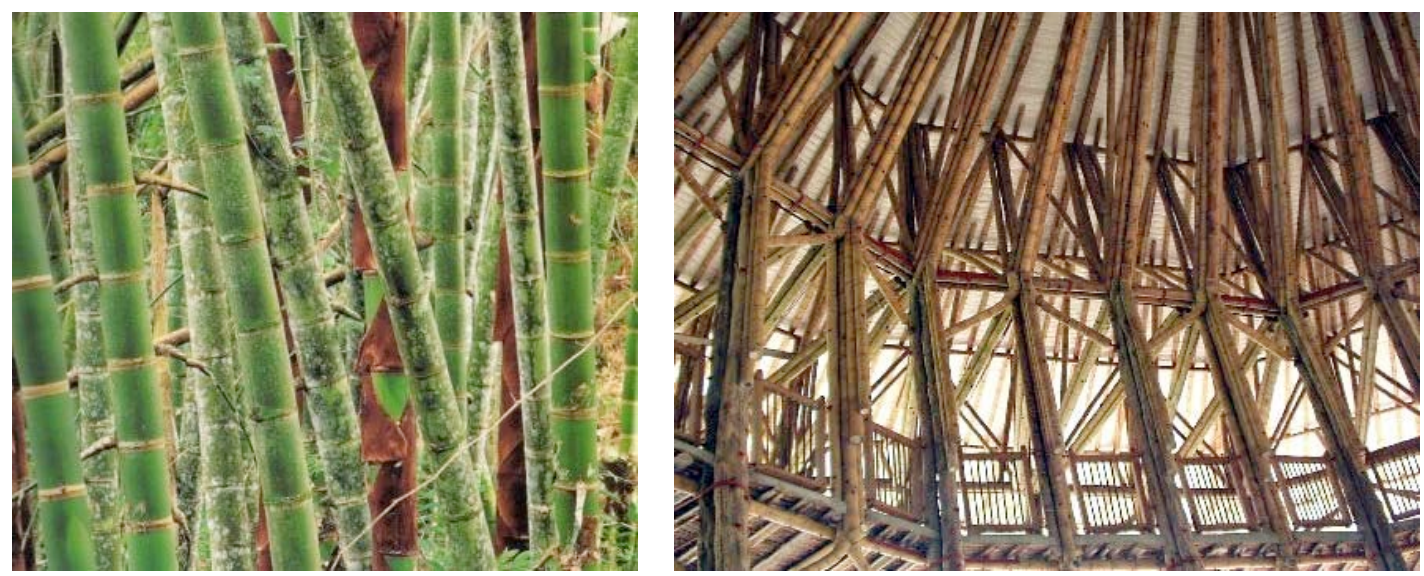

Figuras 53 e 54 - Floresta de Guadua na Colômbia e Guadua no projeto do Pavilhão Zeri (Simón Vélez).

Fontes: VILLEGAS, 2003 (53) e acervo da autora (54).

Assim, faz-se necessário o desenvolvimento de tecnologias construtivas e a difusão de tecnologias apropriadas, formação e capacitação da mão-de-obra para a organização de sistemas produtivos comunitários. Simplificando e universalizando o uso do material bambu como elemento de construção de qualidade, natural, renovável e de rápido crescimento, o 
bambu poderá se consolidar como importante alternativa às múltiplas demandas da construção civil, inclusive às políticas públicas habitacionais.

\subsection{5 - Componentes construtivos em bambu}

A diversidade de espécies e as características físico-mecânicas dos bambus possibilitam o desenvolvimento de variados sistemas construtivos. Conforme já mencionado anteriormente, todo o processo produtivo do material irá determinar a qualidade desempenhada pela construção, mas talvez o item de maior influência na durabilidade seja o projeto.

Sistemas construtivos em bambu podem, assim como outros sistemas, passar por um processo de pré-fabricação, otimizando o processo construtivo. Os colmos podem ser previamente dimensionados e cortados de acordo com o projeto previsto; no entanto, devese predispor de certa flexibilidade de ajustes no momento de efetuar montagem, uma vez que por ser um elemento natural não processado geralmente apresenta variabilidade dimensional.

Janssen (1995) afirma que algumas das propriedades que determinam o melhor uso de bambus são:

- a altura total do colmo;

- a altura útil do colmo (até onde o diâmetro não seja tão pequeno);

- o diâmetro do colmo nas extremidades úteis e no meio;

- a espessura da parede do colmo nas mesmas regiões;

- a distância entre os nós;

- as propriedades mecânicas dos colmos;

- a durabilidade natural e o tipo de preservação aplicado.

Ainda segundo o autor, o bambu e a pré-fabricação podem oferecer consideráveis oportunidades a comunidades carentes de aumentarem a independência econômica e autossuficiência. $O$ bambu pode ser cultivado em pequena escala; a preservação pode ser feita em pequenas oficinas que não necessitam de grandes investimentos iniciais e a construção pode ser facilmente desenvolvida baseada em ajuda mútua, utilizando-se equipamentos simples. 
Sistemas construtivos são compostos por subsistemas como fundações, estrutura, vãos, vedações e cobertura. No caso do bambu pode-se encontrar muitos subsistemas em uma mesma construção, inclusive sendo algumas edificações totalmente compostas pelo material. Certamente alguns cuidados específicos são necessários, tais como proteção contra as intempéries e umidade. Nos próximos itens serão percorridos alguns subsistemas construtivos em bambu produzidos na atualidade, sobretudo no que existe na literatura ocidental sobre o assunto.
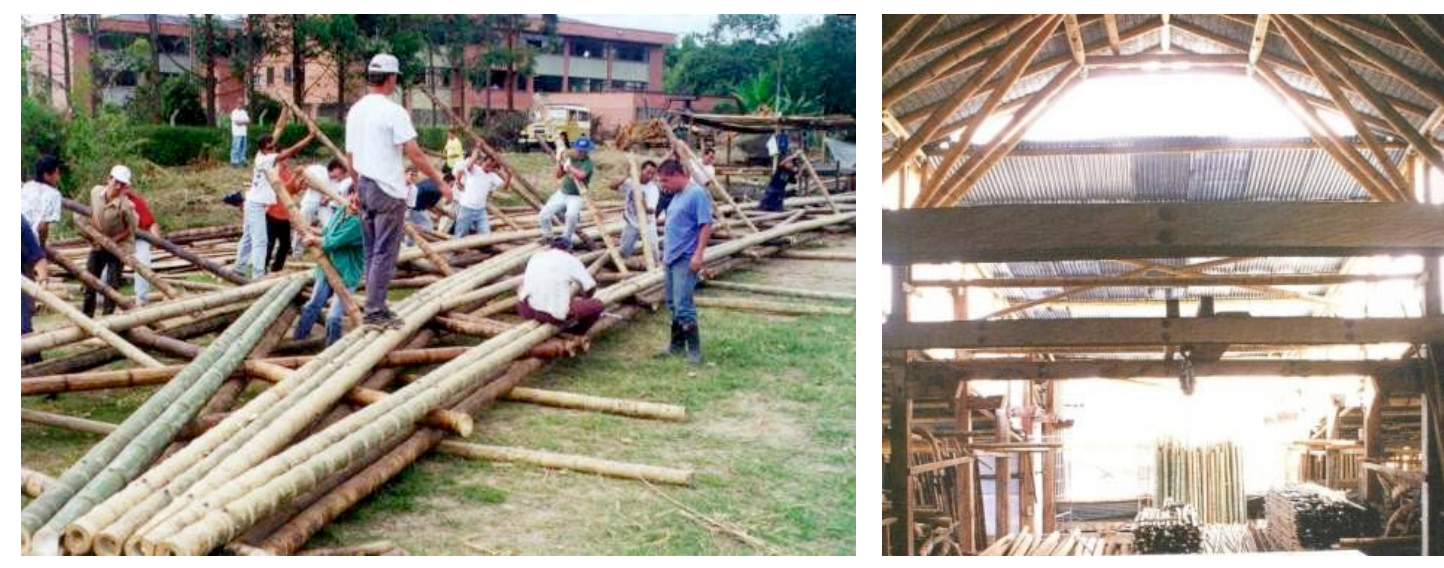

Figuras 55 e 56 - Pré-fabricação de treliças para ponte (Joerg Stamn) e oficina de pré-fabricação de peças em bambu (Marcelo Villegas).

Fonte: http://bambus.rwth-aachen.de/(55) e VILLEGAS, 2003 (56).

\subsubsection{1 - Fundação e piso}

Conforme mencionado anteriormente, uma das mais importantes premissas no tocante à durabilidade do bambu para a construção é a de projeto, ou a famosa "proteção pelo projeto", como afirmam os construtores colombianos. Desta forma, assim como em todos os subsistemas, o projeto destinado às fundações deve sempre considerar alternativas de proteção do bambu frente às chuvas, intempéries e umidade, devido à elevada higroscopicidade que a planta apresenta.

No caso das fundações, é importante prever alguma forma de isolamento do material em relação ao solo, do qual penetra grande parte da umidade, garantindo assim o não apodrecimento de peças e a maior durabilidade da estrutura. Fundações podem ser executadas em pedras, tijolos, concreto, aço ou utilizando qualquer outro material que possa isolar o bambu, mantendo-o livre do contato com a umidade.

Outra medida de projeto preventiva, de acordo com Janssen (1995), é a da previsão de troca de peças. Mesmo isolando os pilares do solo pela fundação, muitos pilares externos 
apresentam vida útil limitada devido à posição vulnerável aos respingos de chuva. Assim, o autor aconselha que haja em projeto a previsão de efetuar tais trocas, sugerindo um possível desenho, conforme Figura 57 e 58.
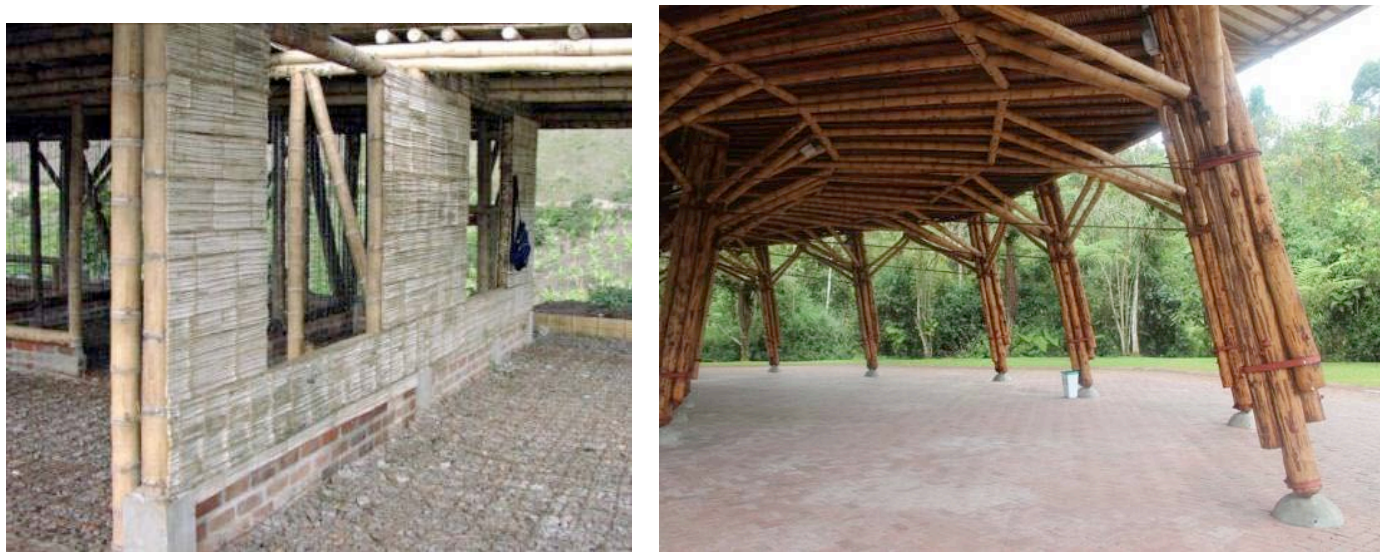

Figuras 57 e 58 - Fundações em tijolos e concreto isolando estruturas e vedação em bambu do solo em residência colombiana (Joerg Stamn) e no Pavilhão Zeri (Simón Vélez).

Fontes: PEREIRA; BERALDO 2008 (57) e acervo da autora (58).

Pelas mesmas questões de proteção à umidade, os pisos em edificações em bambu no caso do pavimento térreo devem ser preferencialmente elevados do solo para impedir o contato direto com a umidade ascendente. Os pisos ou assoalhos executados em bambu apresentam muitas geometrias possíveis, dentre as mais frequentes estão os bambus planificados (esterillas), bambus em tramas, bambus partidos (meia cana) e bambus inteiros (cana inteira), conforme Figura 59.
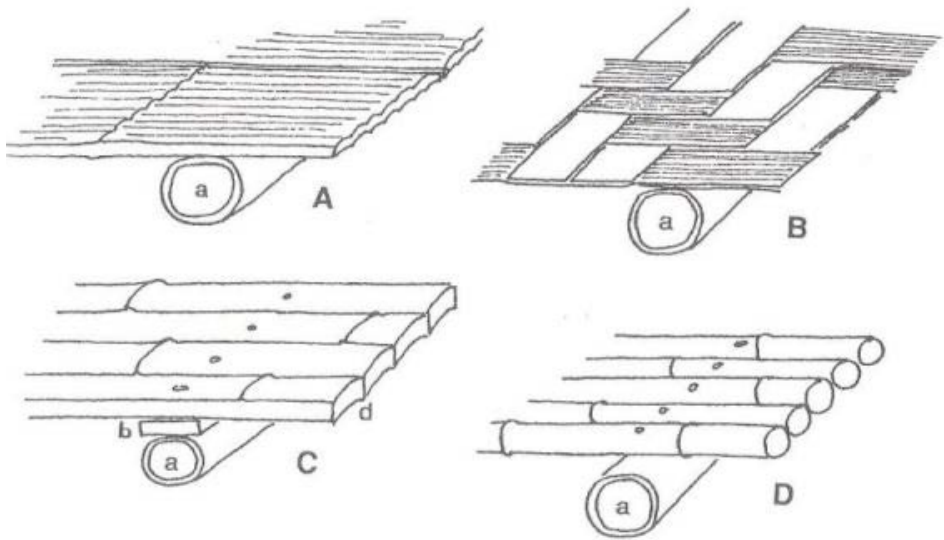

Figura 59 - Possibilidades de piso: A - Esterilla, B - Bambu em trama, C-Meia Cana e D-Cana inteira. Fonte: JANSSEN 1995. 


\subsubsection{2 - Estrutura}

Diferentemente da estrutura em madeira, cuja fabricação geralmente implica em usinagem, a estrutura em bambu é executada com o colmo em sua geometria original. Desta forma, toda a estrutura é montada com colmos inteiros, que se articulam entre si por meio de encaixes, nós, barras roscadas e articulações.

As estruturas em bambu possuem excelente desempenho à tração, pela dimensão e resistência de suas fibras e à compressão, pela geometria dos colmos. Dessa forma, além da tradicional hierarquia estrutural de vigas e pilares o bambu é comumente usado na préfabricação de pórticos, treliças e tesouras. (Figuras 60 a 63)
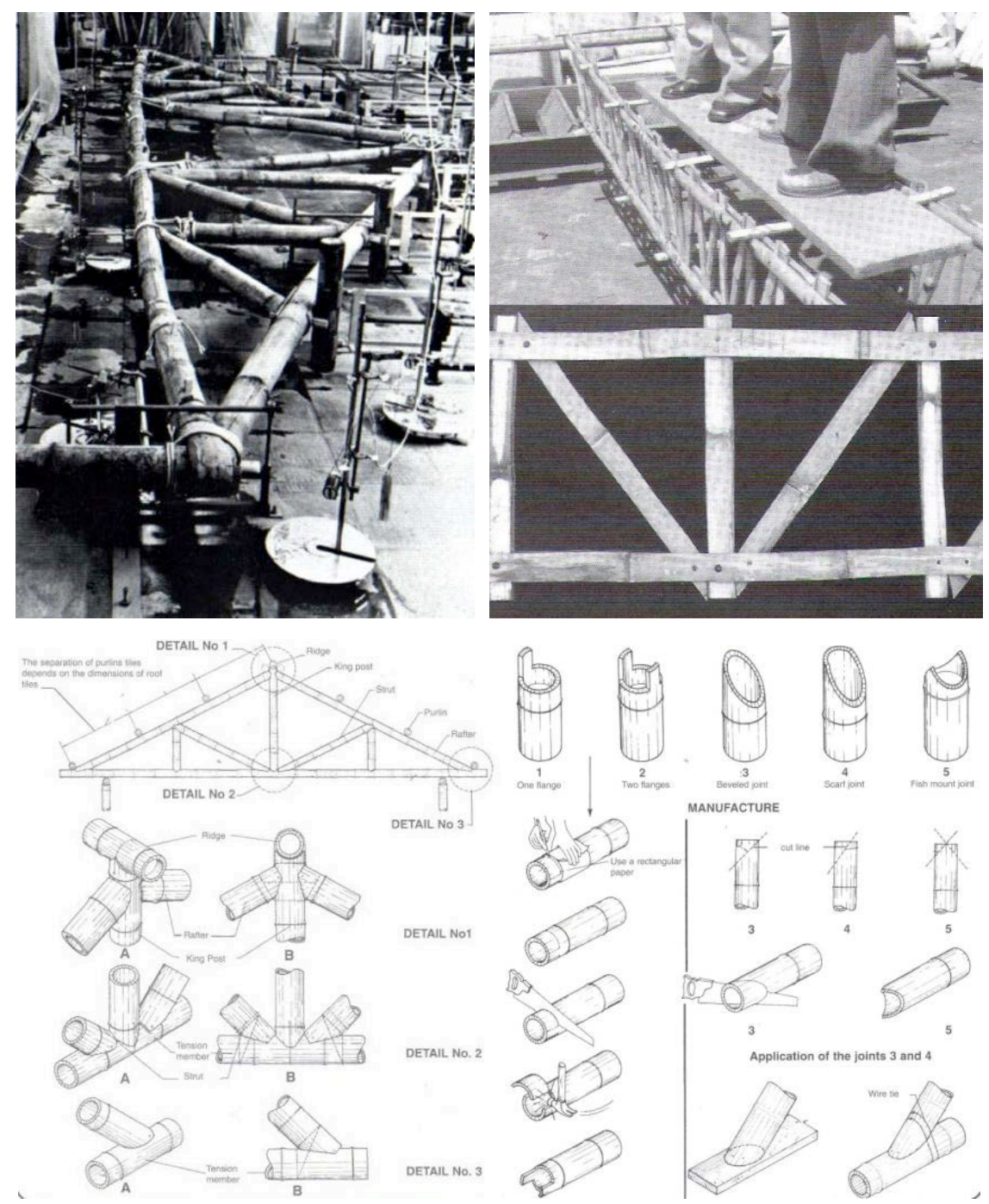

Figuras 60, 61, 62 e 63 - Tesoura em bambus, treliça plana em tiras de bambu e técnicas de encaixe e corte de bambus.

Fonte: JANSSEN 1995 (60) e HIDALGO-LÓPEZ 2003 (61, 62 e 63). 


\subsubsection{3 - Vedação}

Vedações em bambu podem substituir de maneira adequada materiais convencionais, tais como tijolos, blocos de concreto e madeira. Suas geometrias e suas diversas formas de beneficiamento possibilitam efetuarem-se múltiplos arranjos de vedação, como fechamentos duplos, preenchimento interno em argila, paredes ventiladas, podendo contar com formas convencionais de reboco e acabamento (Figuras 64 a 69).

Dentre as mais frequentes vedações existentes na bibliografia revista estão tipos de vedação, tais como:

- Estrutura em colmos inteiriços e fechamento em trama de tiras de bambu;

- Estrutura em colmos inteiriços e fechamento em dupla parede de trama de tiras de bambu preenchidas com argila;

- Estrutura em colmos inteiriços e fechamento em dupla parede de esterillas;

- Estrutura em colmos inteiriços e fechamento em trama de tiras de bambu;

- Estrutura em colmos inteiriços e fechamento com colmos inteiriços sobrepostos;

- Estrutura em colmos inteiriços e fechamento com colmos abertos e prensados.
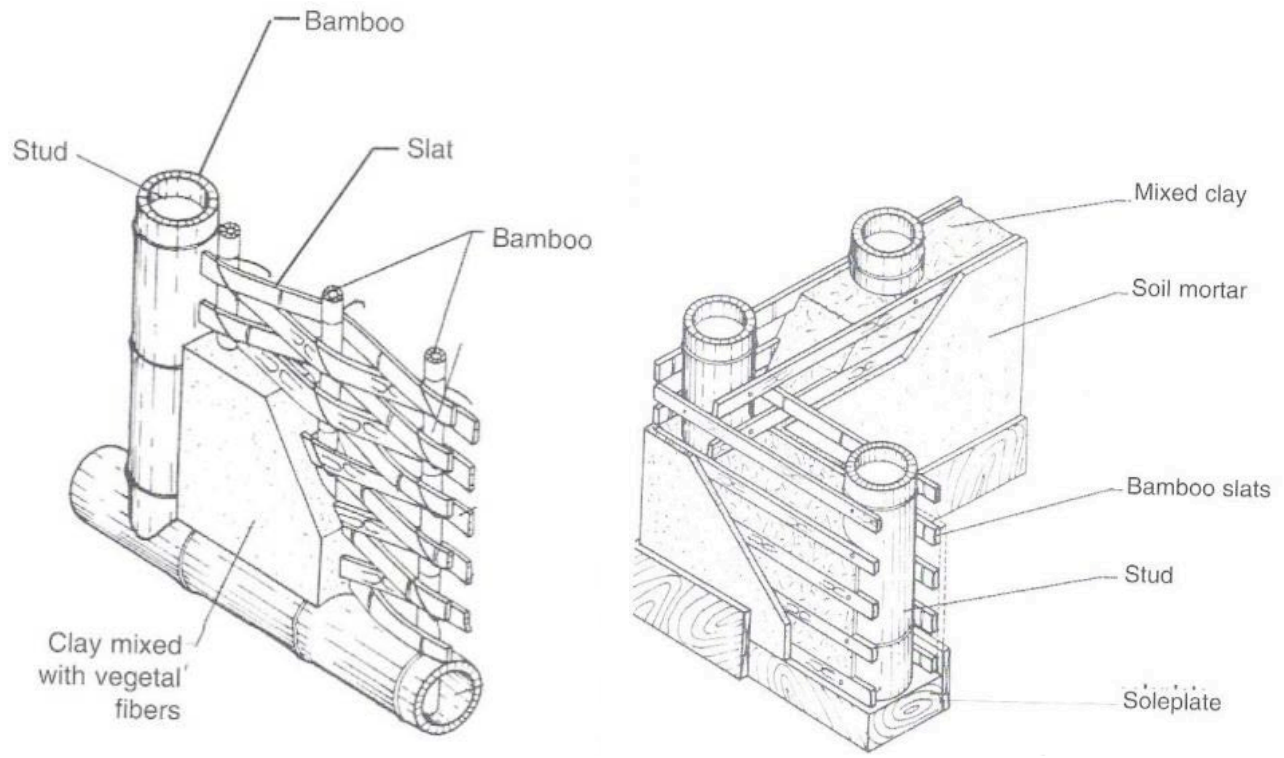

Figura 64 - Vedações tipo 1 (de origem Peruana) e 2 (de origem Colombiana).

Fonte : HIDALGO-LÓPEZ 2003. 

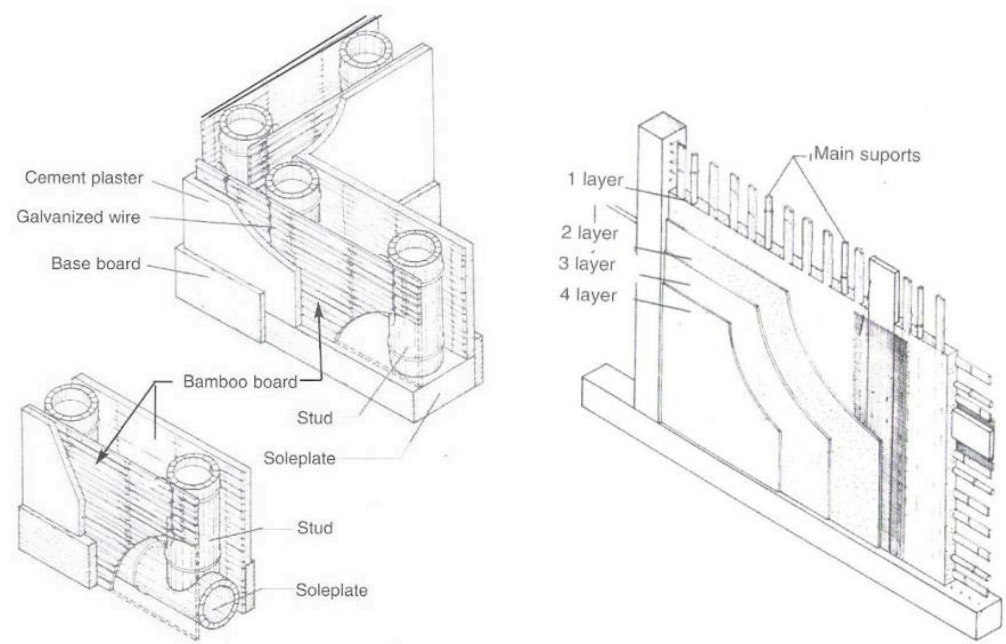

Figura 65 - Vedações tipo 3 (de origem Colombiana) e 4 (de origem Japonesa).

Fonte : HIDALGO-LÓPEZ 2003.
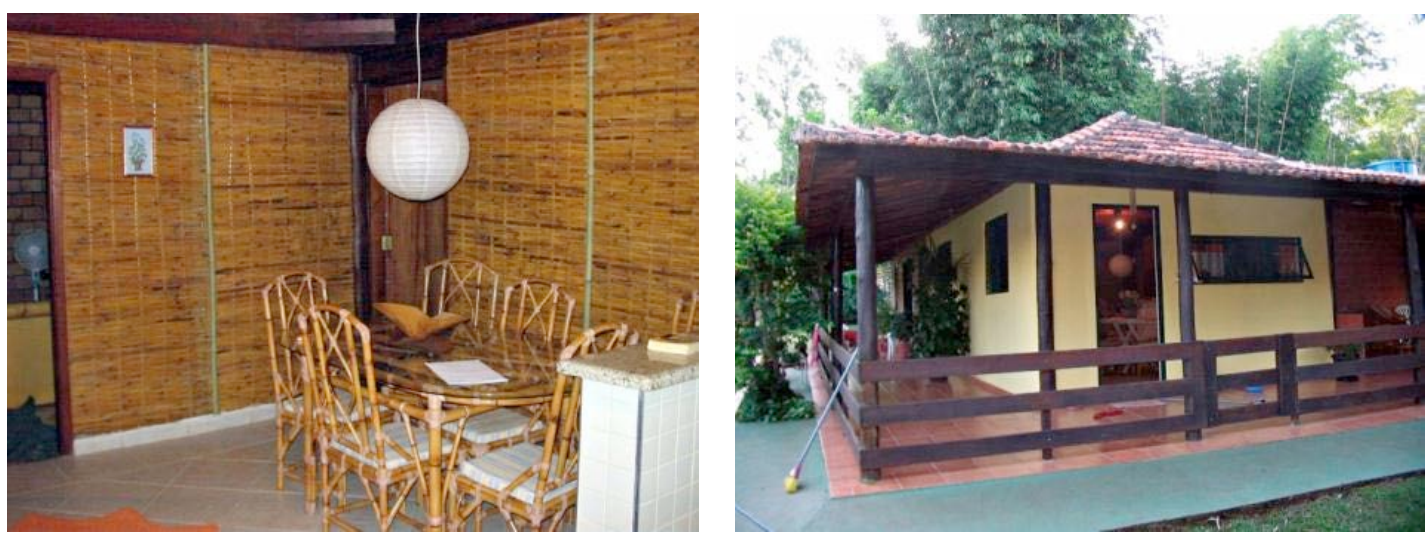

Figuras 66 e 67 - Casa em Bauru com parede dupla em trama de bambu revestida externamente. Fonte: PEREIRA; BERALDO 2008.
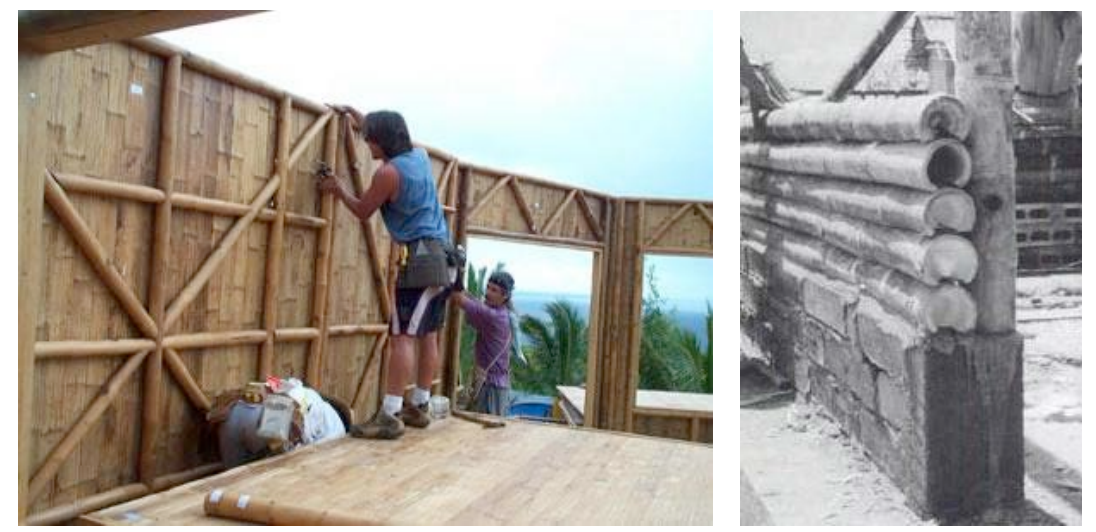

Figuras 68 e 69 - Fechamento em colmos abertos e prensados nos EUA (tipo 6) e fechamento com colmos inteiriços sobrepostos (tipo 5) no Equador (Gernot Minke).

Fontes: http:// www.bambootechnologies.com (68) e KENNEDY 2004 (69). 


\subsubsection{4 - Cobertura}

Apesar de limitada durabilidade frente às degradações do meio, coberturas em bambu podem ser executadas em regiões com baixa pluviometria e visando à substituição de peças, dada a grande produtividade do material. Em geral, a técnica construtiva desenvolvida para esse subsistema baseia-se na própria geometria do colmo para formar o sistema capa-canal. Secciona-se longitudinalmente o colmo ao meio, e desobstruindo os diafragmas, forma-se uma meia cana que pode ser usada como calha em toda sua extensão, ou pode ser subdividida em telhas, conforme Figuras 70 e 71 . É necessário salientar no entanto o grande risco de degradação que o subsistema de cobertura em telhas de bambu sofre, visto que é altamente recomendada em projeto a proteção do material às intempéries.

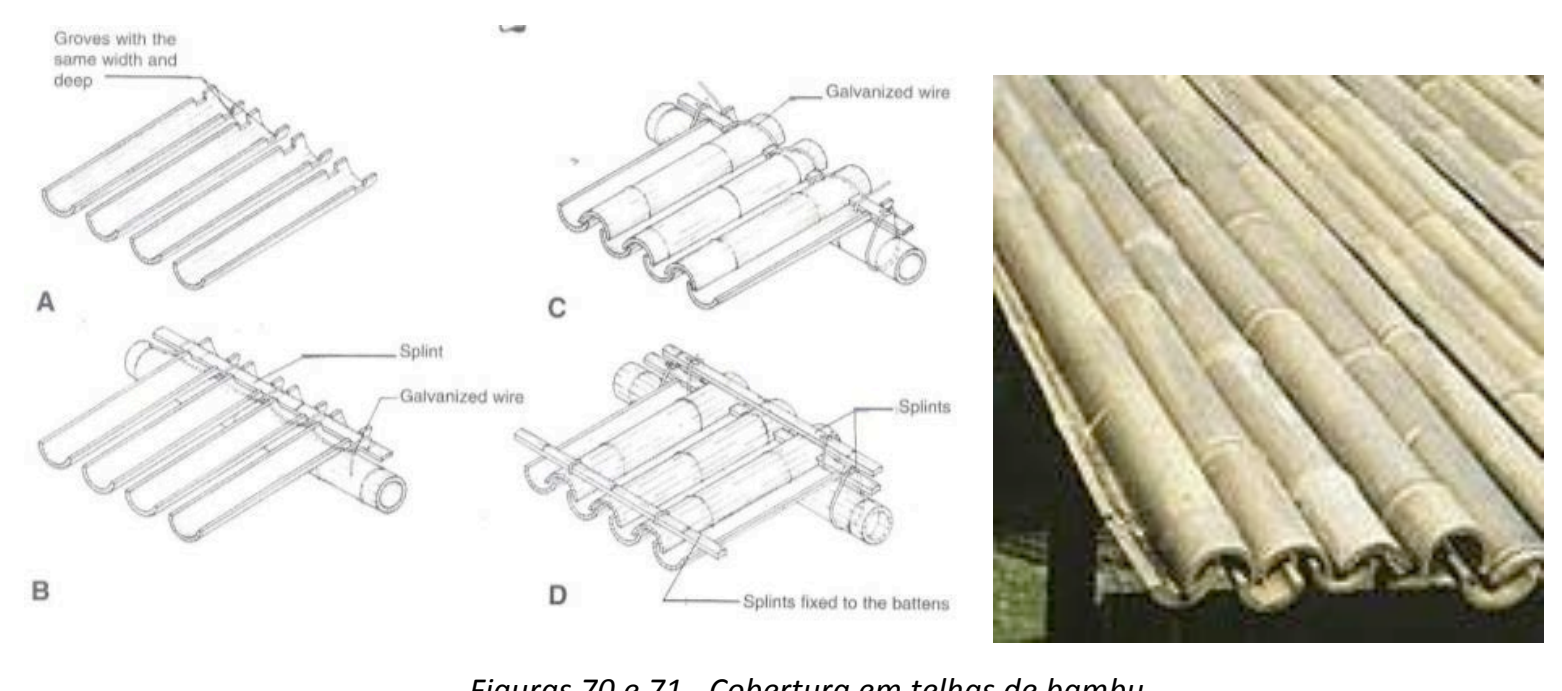

Figuras 70 e 71 - Cobertura em telhas de bambu.

Fonte: HIDALGO-LÓPEZ 2003 (70) e DETHIER; STEFFENS 2000 (71).

\subsubsection{5 - Malha}

Dada a excelente flexibilidade do material e à elevada resistência à tração, o bambu também apresenta um bom desempenho na distribuição dos esforços em malhas trançadas, que podem ser utilizadas como fôrmas perdidas na concretagem de cascas (Figuras 72 a 74). 

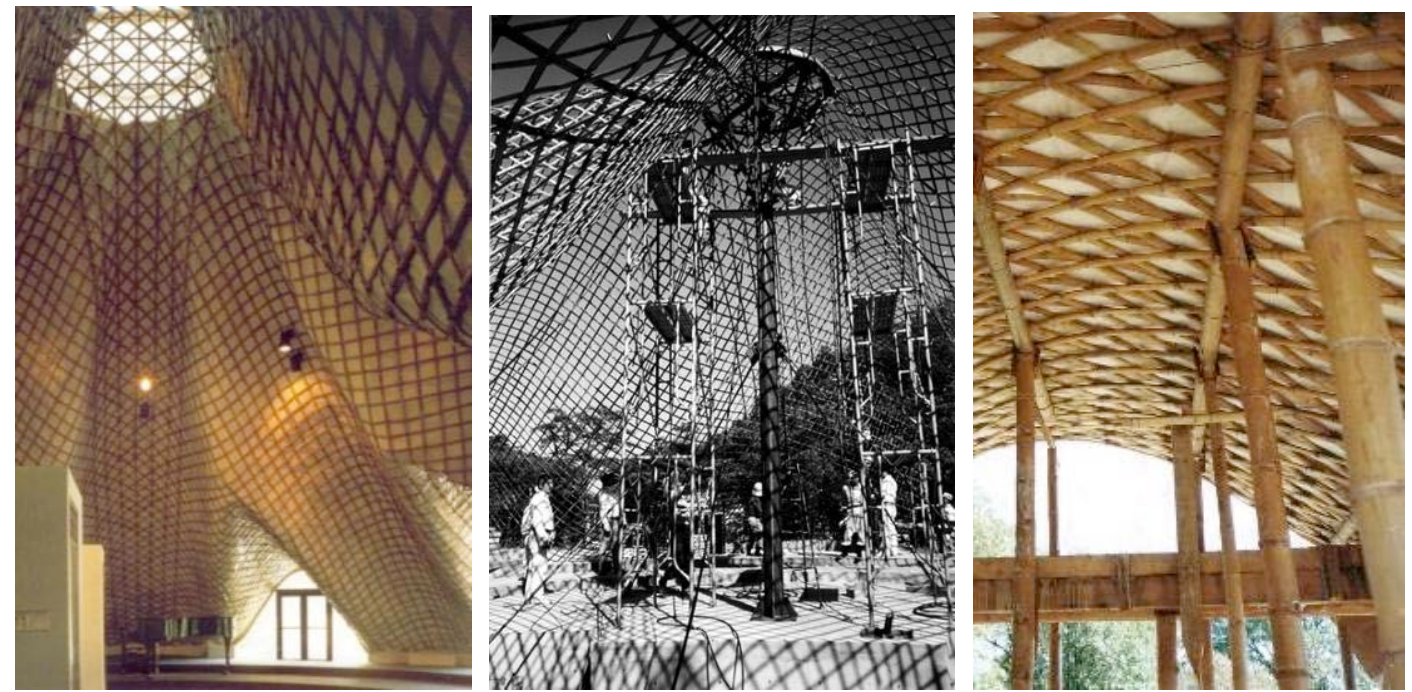

Figuras 72, 73 e 74 - Centro Residencial no Japão (Shoei Yoh) e Casa Tarumã em Botucatu (Leiko Motomura).

Trama de bambu servindo como fôrma para a cura do concreto.

Fontes: http://www.arcprospect.org (72 e 73) e http://www.amima-arquitetura.com (74).

\subsubsection{6 - Fibras em componentes cimentícios}

Compósitos cimentícios utilizando partículas de bambu são interessante solução para utilização dos resíduos provenientes de seu processamento. Nesse sentido, o Prof. Dr. Antonio Ludovico Beraldo, da FEAGRI - UNICAMP, desenvolveu uma série de experimentos visando melhor adequar os componentes bambu e cimento, uma vez que o amido existente no bambu inibe a pega do cimento. Algumas alternativas foram encontradas para contornar esse inconveniente, como a imersão das partículas em soluções alcalinas, o uso de cimento de pega rápida (CP V-ARI) ou de aditivos aceleradores de pega como cloretos e sulfatos. $\mathrm{O}$ produto de tais pesquisas é o Biokreto, compósito de biomassa-vegetal-cimento, possibilitando a obtenção de uma gama de subprodutos. (Figura 75)

\subsubsection{7 - Armação em concreto}

Também conhecido como bambucreto, a armação de concreto com bambu é uma boa opção para obras de menor porte, com vão de até 3,5 m, não sendo, no entanto, um material que venha substituir o aço, pois o módulo de elasticidade do bambu é cerca de dez vezes mais baixo (PEREIRA; BERALDO, 2008). Seu uso deve estar atento a questões como amadurecimento do colmo, a correta impermeabilização do colmo e o aumento da rugosidade da peça para que ocorra a devida aderência ao concreto. No Brasil, a maior parte 
das pesquisas sobre o tema é conduzida pelo Prof. Khosrow Ghavami, da PUC - RJ. (Figura 76)
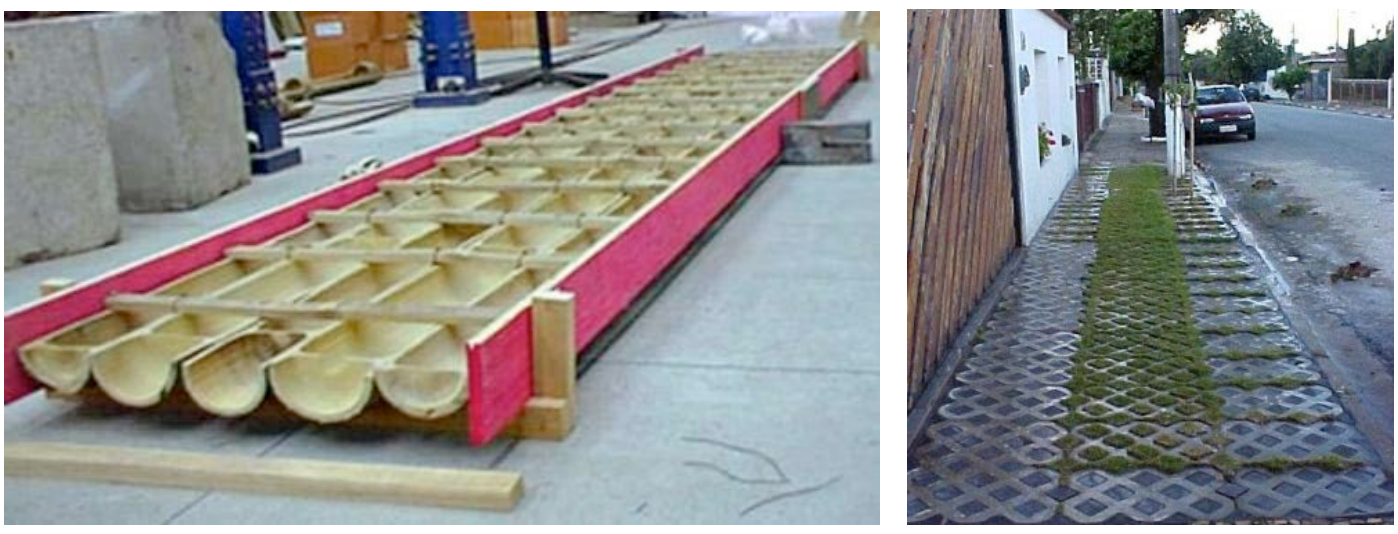

Figuras 75 e 76 - Fôrma para concreto com armação em bambu (Prof. Ghavami) e Biokreto (Prof. Beraldo).

Fontes: PEREIRA; BERALDO 2008.

\subsubsection{8 - Laminados}

Assim como a laminação da madeira, a laminação o bambu é uma boa alternativa para a otimização do uso do material, possibilitando a geração de novas formas e novas funções e agregando maior valor à sua produção. Alguns de seus subprodutos possíveis: vigotas, pisos, chapas, painéis, pranchas, movelaria, entre outros. Deve-se levar em consideração, no entanto, a pequena dimensão da parede do colmo de onde se extrai a ripa - componente básico do laminado - restringindo assim o uso de grandes peças de laminado devido à utilização de quantidade significativa de adesivo - o componente de maior custo.

No Brasil, a maior parte das pesquisas sobre bambu laminado colado são conduzidas pelos professores Marco Antonio Pereira, da UNESP - SP e Carlos Alberto Szücs, UFSC - SC.
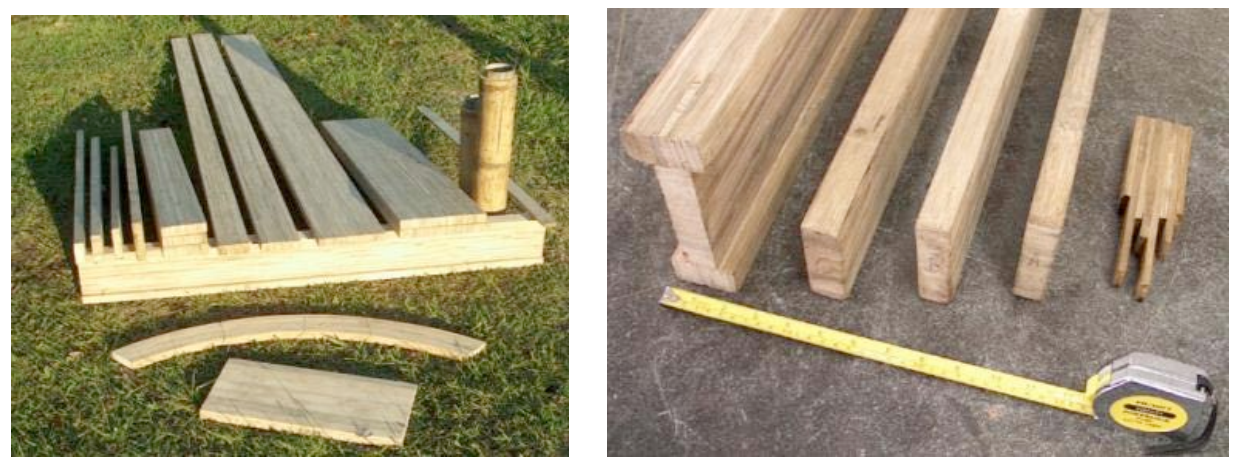
Figuras 77 e 78 - Perfis compostos por bambu laminado.

Fonte: $h t t p: / / w w w . e c o b a m b o o . n e t /$.

\subsubsection{9 - Conexões}

A geometria e a composição do bambu em sua forma natural é importante fator na determinação do tipo de conexão a ser empregada. Seu formato oco, longitudinal, sua variação nos diâmetros e sua composição basicamente por longas fibras paralelas define a necessidade de sistemas de conexão que diferem muito dos sistemas utilizados na madeira. Dessa forma, a escolha e desenvolvimento de conexões para bambu vem sendo um tema cada vez mais pesquisado, visto que representa o sucesso ou fracasso de uma estrutura. (Figura 79)

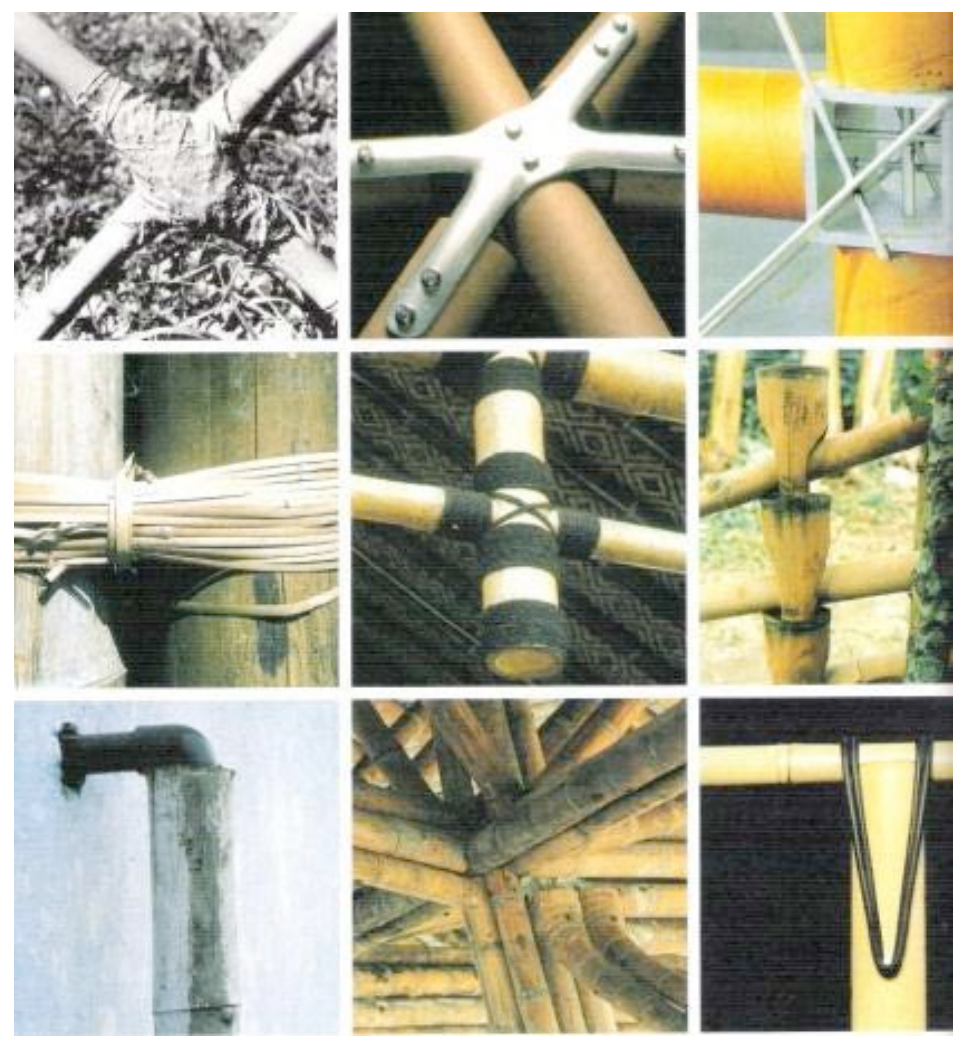

Figura 79 - Possibilidade de nós e conexões.

Fonte: DETHIER; STEFFENS 2000.

Tradicionalmente, nas culturas orientais, as conexões eram executadas em cordas ou fibras naturais como junco, ráfia, coco e até em tiras extraídas do próprio bambu. Alguns povos nômades da China e Tailândia a cada 15 anos tendiam a buscar um novo local para estabelecimento. Neste processo, as habitações estruturadas em bambus amarrados com 
tais fibras, eram simplesmente desmontadas e remontadas no novo local, sendo totalmente reaproveitadas (DETHIER, STEFFENS 2000).

Marçal (2008) afirma que apesar de muito resistentes, tais conexões não oferecem tanta durabilidade às estruturas, e mais do que isso, em algumas delas tende-se a não usar o bambu de uma forma adequada, ameaçando o processo de fendilhamento de tais peças. 0 autor enfatiza que não é o material que determina o insucesso de uma conexão, mas sim a forma de encaixe e sua adequação com as forças atuantes na estrutura, e a resistência necessária que ela deve desempenhar.
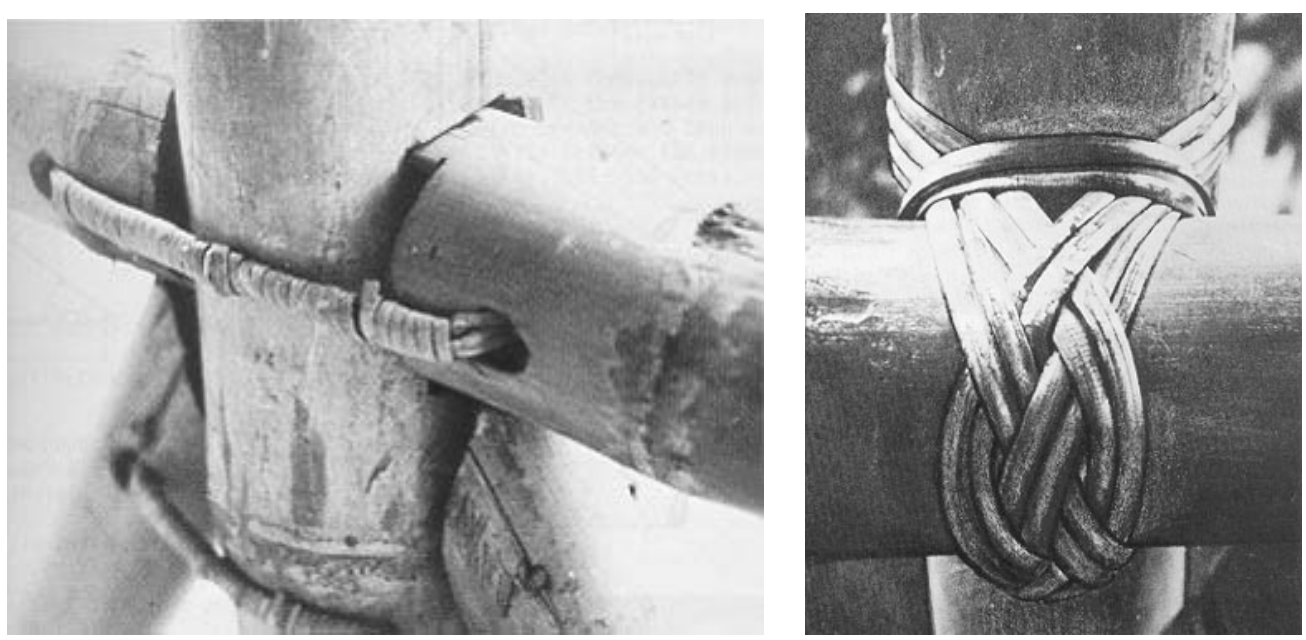

Figura 80 - Conexões em junco.

Fonte: http://bambus.rwth-aachen.de/

Conforme já mencionado, o bambu é possuidor de longas fibras paralelas e estas quando afastadas provocam a abertura de fendas que tendem a fendilhar-se. Desta forma, o material é pouco resistente a pregos e grampos, sendo preferível o emprego de conexões parafusadas, uma vez que tal procedimento provoca um corte nas fibras, e não um afastamento (TEIXEIRA 2006).

Inúmeras são as possibilidades de conexões e seus materiais, que podem classificarse em perfuráveis ou não-perfuráveis, preenchidas ou não-preenchidas, e podem ser executadas por amarrações, elementos metálicos, elementos em madeira, elementos moldados e outras. Dentre elas as mais recorrentes são: 
Mais frequente conexão da arquitetura tradicional colombiana, a boca de pescado possui muitas variações. Ela consiste no encaixe entre duas peças roliças de bambu através de um corte curvilíneo em uma das peças, de forma que esta envolva a segunda peça como uma boca de um peixe. Assim, uniformemente apoiada, a peça é conectada à outra, geralmente por elementos metálicos como abraçadeiras, barras roscadas, porcas e arruelas.
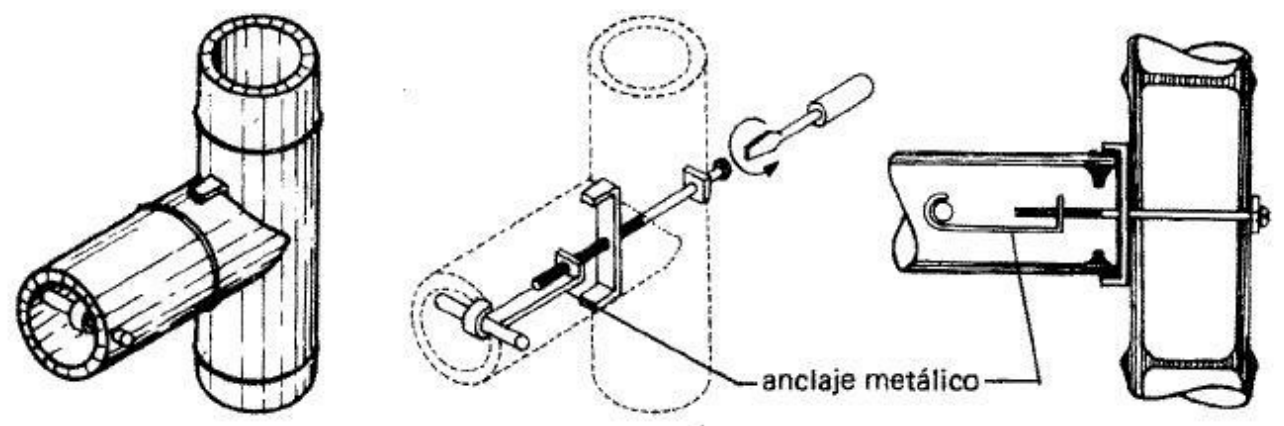

Figura 81 - Conexão em boca de pescado.

Fonte: http://www.guaduabamboo.com/

É importante que o corte seja perfeito para que ocorra a distribuição de cargas de maneira uniforme, evitando a possibilidade de cisalhamento. Por esse fator, representa um encaixe mais elaborado em termos de carpintaria é de lenta execução caso a cultura construtiva local não tenha essa técnica já incorporada. No caso dos colombianos, o procedimento é banal, e seus executores o realizam com grande facilidade.

Esta conexão possibilita muitas variações, desde a forma como a boca de pescado é cortada até o ângulo de encaixe entre os colmos. Para garantir maior rigidez e distribuição dos esforços nos pontos de conexão sem sobrecarregar os pontos perfurados, costuma-se preencher os entrenós perfurados com graute (MARÇAL, 2008).

\section{Elementos metálicos}

Transferem ao bambu o mesmo comportamento de treliças metálicas. Neste caso é necessário atenção para que a solicitação de esforços nas extremidades das peças não cause rachaduras, visto que muitas vezes essas conexões não possuem nenhum elemento de preenchimento do interior do colmo perfurado (Figuras $82,83,84$ e 85 ). 

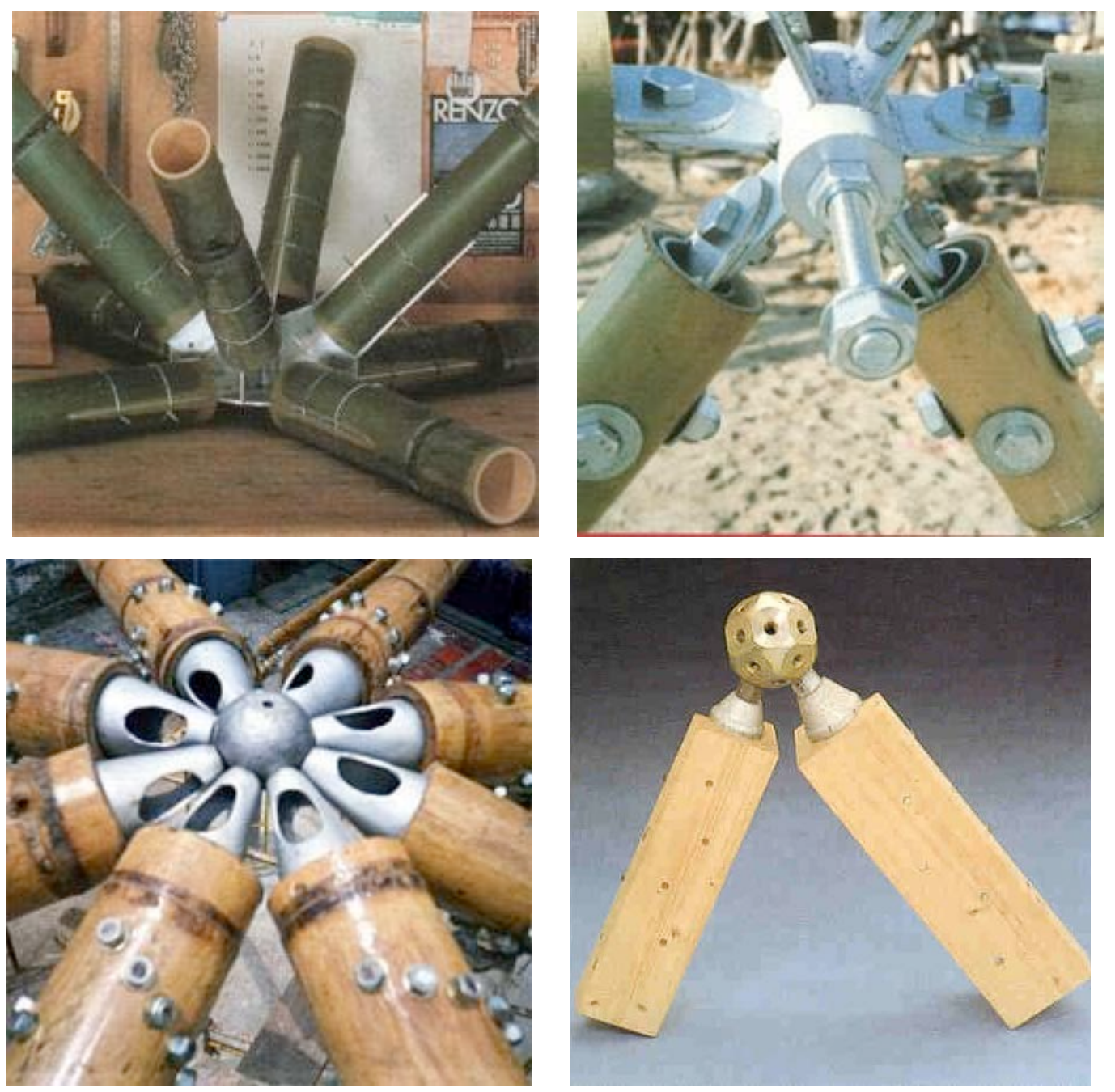

Figuras 82, 83, 84 e 85 - Conexões metálicas desenvolvidas por:

Renzo Piano, Shoei Yoh, Tim Obermann e Max Mengeringhausen.

Fonte: DETHIER; STEFFENS 2000 (82 e 83), MARÇAL 2008 (84) e STAMN 2001 (85)

\section{Elementos de madeira}

Desempenham função similar aos elementos metálicos mas com algumas vantagens. No caso do sistema ilustrado na Figura 86, a peça de madeira tem a função de transferir os esforços entre a peça metálica e o bambu. A madeira possui fibras menores sendo assim mais resistente às solicitações da peça metálica. Portanto, a peça metálica não entra em contato direto com o bambu, diminuindo as chances de ocorrerem rachaduras. A boa integração entre os materiais madeira e bambu garante uma distribuição dos esforços em tais pontos críticos. 

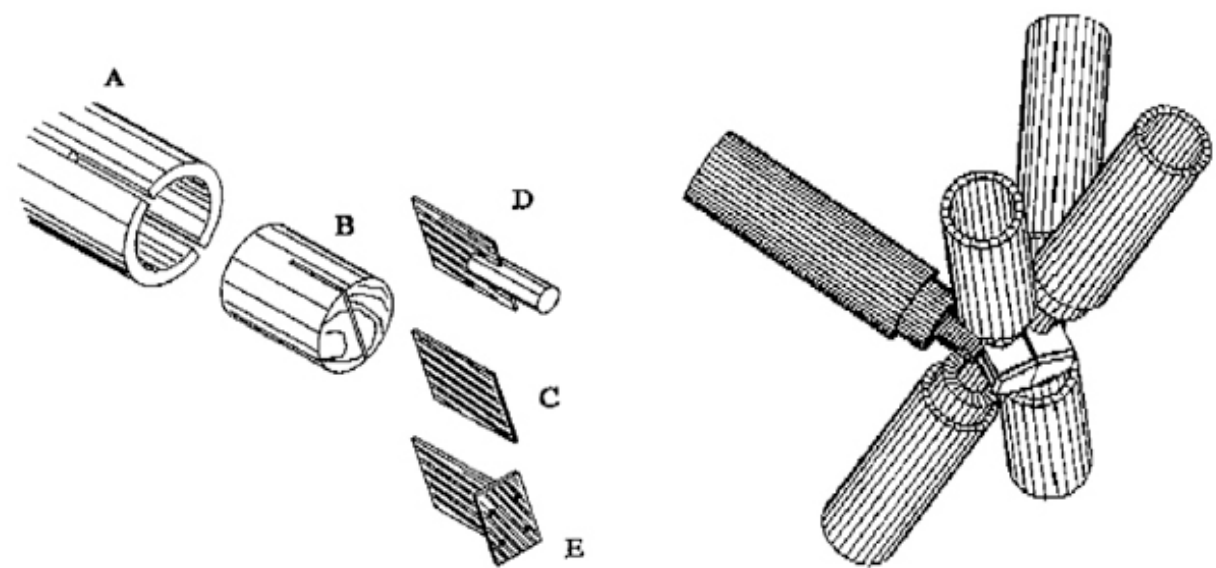

Figura 86 - Conexão em elementos de madeira.

Fonte: http://bambus.rwth-aachen.de/

\section{Conexão Simón Vélez}

A chamada "Conexão Simón Vélez" corresponde atualmente a uma das mais empregadas em obras de grande porte. Vélez, responsável pelas maiores obras em bambu no mundo, costuma atrelar elementos metálicos de conexão, graute no interior dos colmos solicitados e pedaços de madeira como calços. Também utiliza cintas metálicas com o intuito de impedir as rachaduras longitudinais nos colmos. A conexão de Vélez é atualmente a única conexão presente na Norma técnica colombiana de conexões em guadua NTC 5407 (Uniones en estructuras de guadua).

\section{Elementos moldados}

Compostos geralmente por fibras naturais e resinas, tais conexões se caracterizam pela total aderência com a superfície das barras de bambu. A principal vantagem deste sistema é não necessitar de perfurações nas peças, protegendo as fibras e possibilitando reaproveitamento das mesmas. Um exemplo desse sistema é a conexão desenvolvida por alunos da Escola de Engenharia da Universidade Federal de Minas Gerais. A peça conectora é feita a partir de tecido e foi recentemente patenteada. 


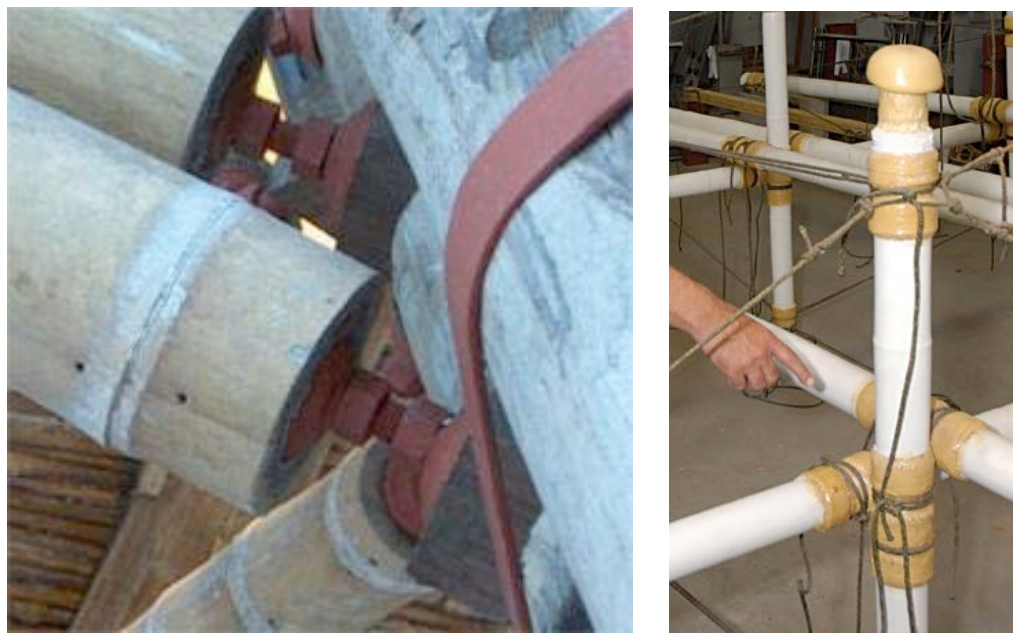

Figuras 87 e 88 - Conexão Simón Vélez e conexão em tubos moldados de tecido da UFMG.

Fonte: MARÇAL 2008 (87) e https://www.ufmg.br/(88).

\subsection{6 - Normatização}

A INBAR (International Network for Bamboo and Rattan) atua com o apoio de seus 22 membros na função de estruturadora de bases para o desenvolvimento de medidas que promovam o uso do bambu e do junco para fins socialmente sustentáveis. Nesse sentido, o órgão possui importante papel regulador junto à ISO (International Standardization Organization) para a implementação de normas específicas internacionais, tanto para procedimentos de realização de ensaios quanto na implementação de normas específicas para o projeto estrutural em bambu.

A Colômbia possui uma série de normas técnicas nacionais em todo processo produtivo do bambu guadua, desde sua extração, secagem, até o seu projeto, inclusive nos detalhes de suas conexões. Além disso, a guadua atualmente faz parte dos materiais permitidos pela norma de construções sismo-resistentes existentes na Colômbia, a NSR-10 (Reglamento Colombiano de Construcción Sismo Resistente). Tal norma é responsável por regulamentar as construções sujeitas aos sismos e foi promulgada em 2010, após três anos em teste. Dentre outras importantes normas colombianas sobre o uso da guadua pode-se citar:

- NTC 5300. “Cosecha y Poscosecha de los culmos de Guadua angustifolia Kunth".

- NTC 5301. "Preservación y secado del culmo de Guadua angustifolia Kunth".

- NTC 5405. "Propagación vegetativa de Guadua angustifolia Kunth".

- NTC 5407. "Uniones de estructuras con Guadua angustifolia Kunth". 
- NTC 5458. "Elaboración de artesanías y muebles con culmos maduros de Guadua angustifolia Kunth".

- NTC 5525. "Métodos de ensayo para determinar las propiedades físicas y mecánicas de la Guadua angustifola Kunth".

- NTC 5726. “Mensura e Inventario de rodales de Guadua angustifolia Kunth para aprovechamientos con fines comerciales".

- NTC 5727. "Terminología aplicada a la guadua y a sus processos" .

- NTC 5829. "Obtención de latas y tablillas de Guadua angustifolia Kunth”.

No Brasil, a elaboração de uma norma específica para a construção em bambu encontra-se em andamento atualmente, sendo muitas vezes realizadas adaptações interpretando as normas existentes sobre madeira no país. ${ }^{17}$

\subsection{7 - Pré-fabricação de habitação}

O Brasil situa-se hoje diante de um déficit habitacional de aproximadamente seis milhões de unidades. A maior parte da população envolvida na questão da crise habitacional não pode ser contemplada pelos programas de financiamento oferecidos pelo governo e os sucessivos períodos de instabilidade financeira tornaram a habitação um bem intangível para toda essa parcela. O enfrentamento de tal questão deve ser feito não somente sob o aspecto quantitativo e produtivo, mas também visando à participação do usuário no processo de tomada de decisão e respeitando a pluralidade material e cultural que é sensível em nosso país. Novas alternativas devem ser buscadas, visando à busca por tecnologias e projetos adequados a tais premissas.

Nesse contexto, a prática da pré-fabricação de habitação atenderia adequadamente as questões produtivas e quantitativas, devendo sempre estar vinculada às decisões dos usuários. Segundo Sánchez e Tole (2008), a pré-fabricação é um conceito associado à otimização do processo construtivo de um elemento, assumindo o elemento pré-fabricado como um material de construção por si só. Assim, a pré-fabricação de habitação em bambu é uma interessante alternativa para uma produção de baixo custo, maior rapidez, baixo investimento inicial e boa qualidade. Caso seja adequadamente conduzida, esta alternativa pode ser, inclusive, objeto de práticas de organização comunitária para a autoconstrução.

\footnotetext{
${ }^{17}$ ABNT - NBR 7190/97 Projeto de estruturas de madeira
} 
Diante de uma fonte natural, renovável, de baixo custo e alta qualidade como bambu, julga-se necessário um maior investimento no desenvolvimento de pesquisa em tecnologia que desencadeie a difusão de técnicas apropriadas, explorando ao máximo as potencialidades do material e consolidando-o como alternativa viável à construção civil. Tais ações poderiam significar no contexto nacional uma expressiva alternativa à questão do déficit habitacional.

Além disso, o uso do material pode representar uma importante aproximação do usuário com o processo produtivo, contribuindo na formação, geração de emprego e autonomia comunitária. Caracterizaria assim uma ação ecologicamente correta, economicamente viável, culturalmente rica e socialmente justa, sendo considerada de fato, sustentável.

\subsection{Sistemas construtivos em Bambu: o caso Colombiano e projetos de habitação de interesse social.}

\subsection{1 - Arquitetura tradicional Colombiana}

Sendo a Colômbia grande referência latino-americana na produção da arquitetura em bambu, houve um esforço para a viabilização de uma pesquisa de campo no país durante o período de desenvolvimento do mestrado. Fui contemplada pelo Programa Santander de bolsas de Mobilidade Internacional e pude desenvolver estágio em pesquisa junto ao Centro de Investigación de Madera y Guadua (CIBAM), núcleo de pesquisa do Instituto de Investigaciones Tecnologicas da Facultad de Artes Universidad Nacional de Colombia (UNAL), em Bogotá.

O trabalho desenvolvido junto ao CIBAM faz parte de um projeto maior, de nível nacional, de caracterização físico-mecânica da espécie Guadua angustiofolia Kunt presente em cada um dos 33 departamentos do país, para definições no código de construção sismoresistente em vigência no país. O período de trabalho com o laboratório foi de imensa contribuição para a familiaridade com o material. Além do trabalho vinculado à Universidade, as pesquisas de campo, desenvolvidas sobretudo na zona cafeeira colombiana, foram de extrema importância para a compreensão de um estado da arte da construção em bambu muito distinto daquele que se encontra no Brasil.

Assim como a brasileira, a construção tradicional colombiana sempre esteve intimamente relacionada com os materiais existentes em seu meio natural mais próximo. Madeira, bambu, terra e fibras vegetais foram materiais essenciais de aporte às construções locais, sobretudo em construções populares, gerando assim uma cultura específica em todos seus processos construtivos e aplicações (SÁNCHEZ; TOLE, 2008). 
A prática do uso do material existe desde épocas pré-hispânicas, sendo as tribos indígenas Quimbayas os primeiros expoentes em sua utilização. Hoje o seu emprego simboliza um marco cultural nos departamentos colombianos de Antioquia, Caldas Risaralda, Quindío e Valle del Cauca (DELGADO 2000).

Denominada a Zona cafeeira colombiana, a região entre a cadeia central e ocidental da Cordilheira dos Andes representou, assim como o Vale do Ribeira, uma região de difícil acessibilidade devido às suas condições naturais, justificando o manejo dos recursos naturais locais no processo construtivo popular bem como a resistência de tais práticas tradicionais. Técnicas construtivas como o bahareque ${ }^{18}$ tiveram sua gênese no conhecimento empírico, quase sempre executadas pelo próprios usuários e mantiveram-se sendo empregadas constantemente através de gerações.

Segundo Gutiérrez (2000), as diferentes tipologias de edificações tradicionais existentes nessa região possuem características específicas que podem ser divididas em quatro gêneros de acordo com o contexto social:

1. Tipologias rurais: edificadas por camponeses em pequenos vilarejos, grandes fazendas ou pequenas propriedades de terra no interior. A guadua é muito empregada na maior parte das edificações pertencentes a esse grupo, e as novas construções tendem a reproduzir as técnicas tradicionais que em alguns casos são uma sintética mescla de tradições pré-colombianas e espanholas (Figura 89).

2. Tipologias urbanas tradicionais: corresponde aos edifícios localizados nas áreas centrais das principais cidades, como Manizales, Pereira e Armenia. Foram construídas em sua maioria na primeira metade do século $X X$, antes de mudanças causadas pela dominação cultural do International Style ${ }^{19}$, como a introdução da cultura de materiais modernos como a alvenaria e o concreto e a rejeição às praticas construtivas tradicionais. Muitas das edificações assim feitas encontram-se em ótimo estado de preservação (Figura 90).

\footnotetext{
${ }^{18}$ Sistema construtivo constituído a partir de trama de bambus com revestimento de reboco cimentício ou em terra. Muito empregado desde épocas remotas para a construção de habitações indígenas na América.

${ }^{19}$ Estilo arquitetônico referente às primeiras décadas da arquitetura moderna mundial.
} 
3. Tipologias urbanas projetadas: resultado de grande esforço de arquitetos e engenheiros no convencimento do cliente sobre as potencialidades construtivas do uso da guadua. Tal gênero é presente em desde projetos de habitação de interesse social até edificações das classes mais favorecidas (Figura 91).

4. Tipologias urbanas marginais: construídas em grandes áreas de urbanização periférica, utilizando-se do material disponível. O bambu, material de baixo custo e abundante, é muitas vezes o principal componente (Figura 92).

No entanto, o emprego do material muitas vezes indiscriminadamente e sem um cuidado técnico específico leva-o a sofrer alguns problemas estruturais, causados por falhas de proteção, de tratamento do material, de projeto e de manutenção. O resultado dessa baixa elaboração técnica frequentemente empregada é a falta de credibilidade no material, que muitas vezes termina por representar os setores menos favorecidos, e desencadeia na população uma rejeição para com o mesmo.

Outro motivo de diminuição da valorização do material foram os diversos incêndios ocorridos nas grandes cidades da Zona cafeeira, como o de Manizales em 1925. Na zona central, grandes conjuntos de edificações em bahareque com estrutura em guadua sofreram um dos maiores desastres da região.

Mas foi em outro grande desastre, o terremoto de 1999 na Zona cafeeira, com epicentro em Quindío, que foi evidenciada a importância da guadua nas construções sísmicas. Pela grande flexibilidade do material, as edificações construídas em guadua mantiveram-se em bom estado, enquanto que aquelas que foram construídas em alvenaria convencional ruíram em sua maior parte. O episódio do terremoto na Zona cafeeira foi importante para a disseminação de uma série de programas e iniciativas habitacionais públicas e privadas para a reconstrução de habitações utilizando culturas construtivas e materiais tradicionais colombianos, sobretudo a guadua. 

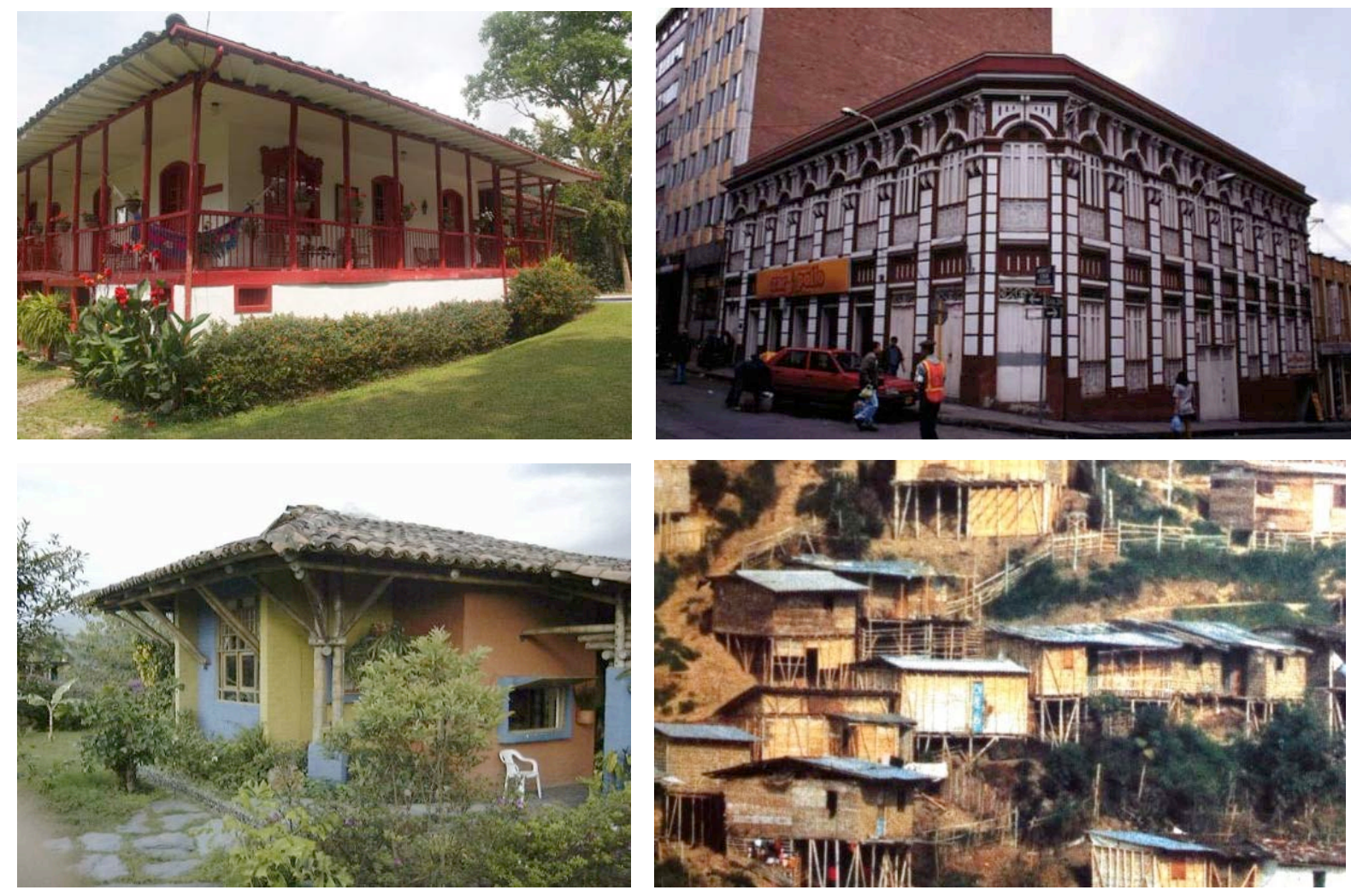

Figuras 89, 90, 91 e 92 - Tipologias de construções tradicionais: rurais, urbanas tradicionais,

urbanas projetadas, e urbanas marginais segundo Gutiérrez (2000).

Fonte: Acervo da autora (89), GUTIERREZ 2000 (90), PEREIRA;

BERALDO 2008 (91) e DETHIER; STEFFENS, 2000 (92).

De acordo com Sánchez e Tole (2008), a Colômbia passa por um momento de grande reconhecimento cultural e científico da guadua, como uma forma de redenção do material para com tal histórica rejeição. É notável atualmente a crescente atividade de pesquisa sobre a guadua: sobre a planta e suas características físicas e botânicas, sobre o processo produtivo que a envolve, sobre otimização do uso do material em seus sistemas e conexões, entre outros aspectos. Os sistemas construtivos estão sendo constantemente revisados e aperfeiçoados e o material aparenta ser de interesse comum não só aos colombianos, mas também a todo universo da construção civil mundial.

Vale lembrar que toda essa releitura de técnicas vernaculares é endossada pela crescente política de conscientização ambiental que as práticas mundiais de produção e consumo estão passando. A demanda por recursos florestais, a sensibilidade frente ao tema da manutenção da biodiversidade, a necessidade de regulagem de níveis de emissão de CO2 levam à necessidade de manejo adequado dos recursos naturais, e a guadua representa um gênero adequado à essas questões, gerando ainda uma importante possibilidade de entrada do país em mercados internacionais. 
Assim, novas práticas construtivas vinculadas a tais materiais são cada vez mais frequentes na Colômbia. Dentre os principais profissionais atuando em projetos que atendem à tais questões pode-se citar: Oscar Hidalgo-López, Simón Vélez, Marcelo Villegas, Simón Hosie, Carlos Vegara, Luís Carlos Ríos (Opción Timagua) e muitos outros atuantes em menor escala.

Oscar Hidalgo-López pode ser considerado um importante tratadista sobre o estado da arte da construção em bambu nas Américas. Seu trabalho permeou os domínios teóricos e práticos, abordando quase todos os aspectos do bambu nativo colombiano, desde cultivos e processos produtivos até os mais diversos métodos construtivos empregados. Segundo Sánchez e Tole (2008), Hidalgo-López analisou grande parte das construções tradicionais colombianas e as aplicações de sua tecnologia.

Já Simón Vélez, de acordo com Delgado (2000), iniciou seu trabalho com madeiras serradas, e posteriormente começou a trabalhar madeiras roliças e bambu. Originário de família de cafeicultores colombianos, o arquiteto desde sempre esteve em contato com a arquitetura em guadua presente nas construções rurais e faz em sua obra uma releitura de tais técnicas. ${ }^{20}$ Uma grande contribuição de Vélez foi o sistema de uniões utilizando barras roscadas e abraçadeiras, assegurando a estabilidade desses componentes com o preenchimento de graute, que conforme já mencionado anteriormente, é a única conexão presente na Norma técnica colombiana de conexões em guadua NTC 5407 (Uniones en estructuras de guadua). Marcelo Villegas é o construtor responsável por desenvolver a maior parte das obras de Vélez, sobretudo seus elementos metálicos de conexão.

Carlos Vegara fez parte de uma geração anterior de construtores e realizou maior parte de suas obras em sua cidade natal, Cali. Sua arquitetura tem características mais fiéis às tradicionais construções colombianas. Sua obra de maior relevância foi o conjunto de construções para o Club Social y Deportivo Cañasgordas em Santiago de Cali (SALAS 2006).

Já o arquiteto Simón Hosie, natural de Bogotá, faz parte de uma recente geração de arquitetos que trabalha a arquitetura em guadua. Seu grande reconhecimento se deu através do Prêmio Nacional de Arquitetura da Bienal de 2004 na Colômbia, conquistado pelo projeto da Casa del Pueblo, uma biblioteca pública projetada e executada pelo arquiteto em Inza, no Departamento de Cauca. Atualmente segue desenvolvendo projetos como o de pedágios na Autopistas del Café, conforme Figura 94.

\footnotetext{
${ }^{20}$ Conforme entrevista realizada com o arquiteto e apresentada em apêndice.
} 

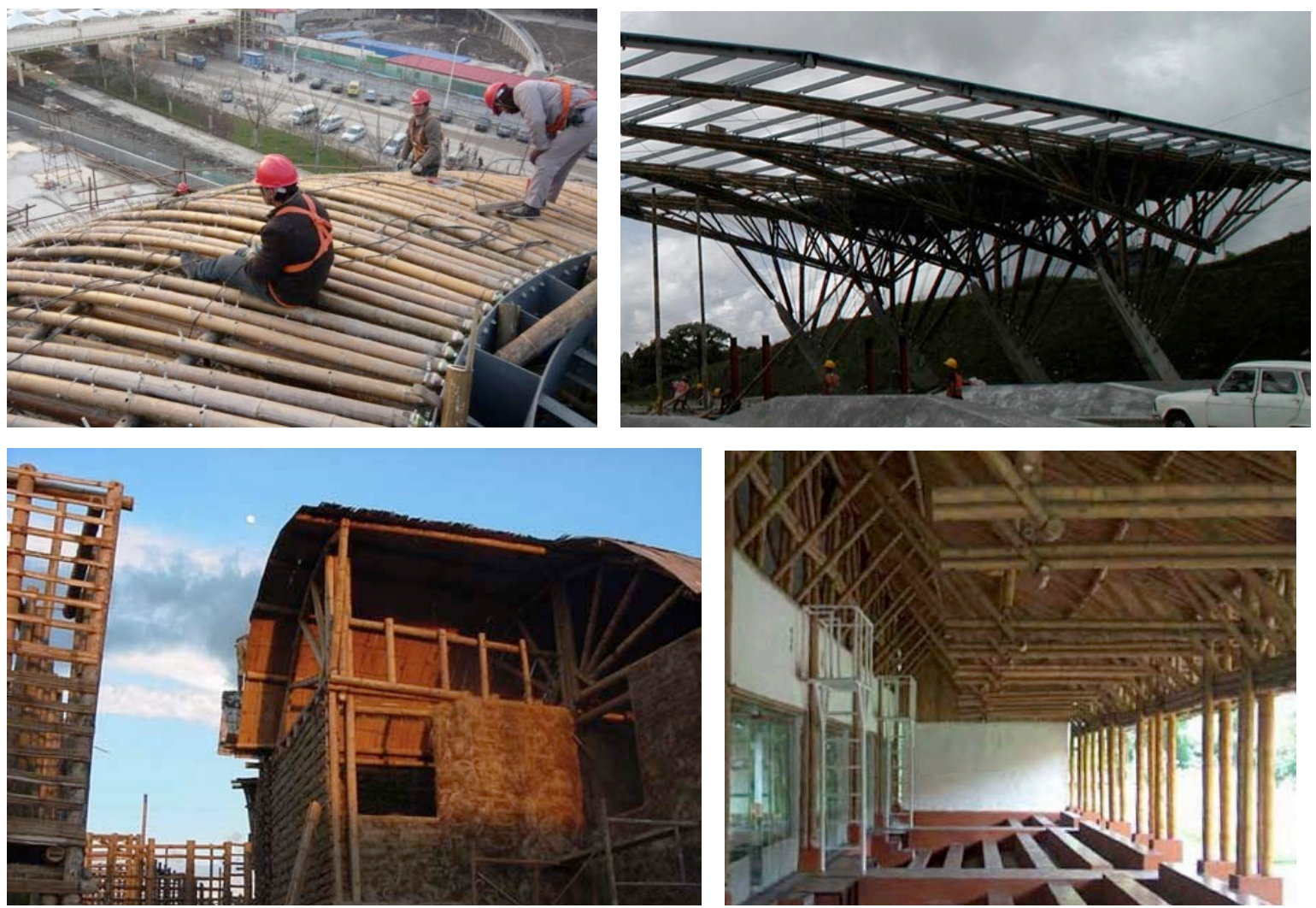

Figuras 93, 94, 95 e 96 - Pavilhão em Xangai (Simón Vélez), pedágio em Circacia (Simón Hosie), bairro Ciudad Alegría em Quindío (Opción Timágua) e Clube em Santiago de Cali (Carlos Vegara).

Fonte: acervo pessoal Simón Vélez (93), http://www. marcelovillegas.com (94), http://www.todoarquitectura.com/(95) e SALAS 2006 (96).

\subsection{2 - Projetos de habitação de interesse social em bambu: referências de processos produtivos}

Assim como o Brasil, a Colômbia e diversos países latino-americanos sofrem com a questão do déficit habitacional em suas principais cidades. Processos de desapropriação, assentamentos humanos precários, e catástrofes que desencadeiam situações de emergência são frequentes e contribuem para este estado de escassez, preocupando o governo e a sociedade civil. Sendo a habitação uma necessidade prioritária do ser humano, é constante a busca por materiais de baixo custo e fácil obtenção, geralmente atrelada à racionalização e à pré-fabricação. Assim, a opção do desenvolvimento de sistemas construtivos em bambu para habitações de interesse social torna-se um tema cada vez mais frequente nos contextos dos países latino americanos. 

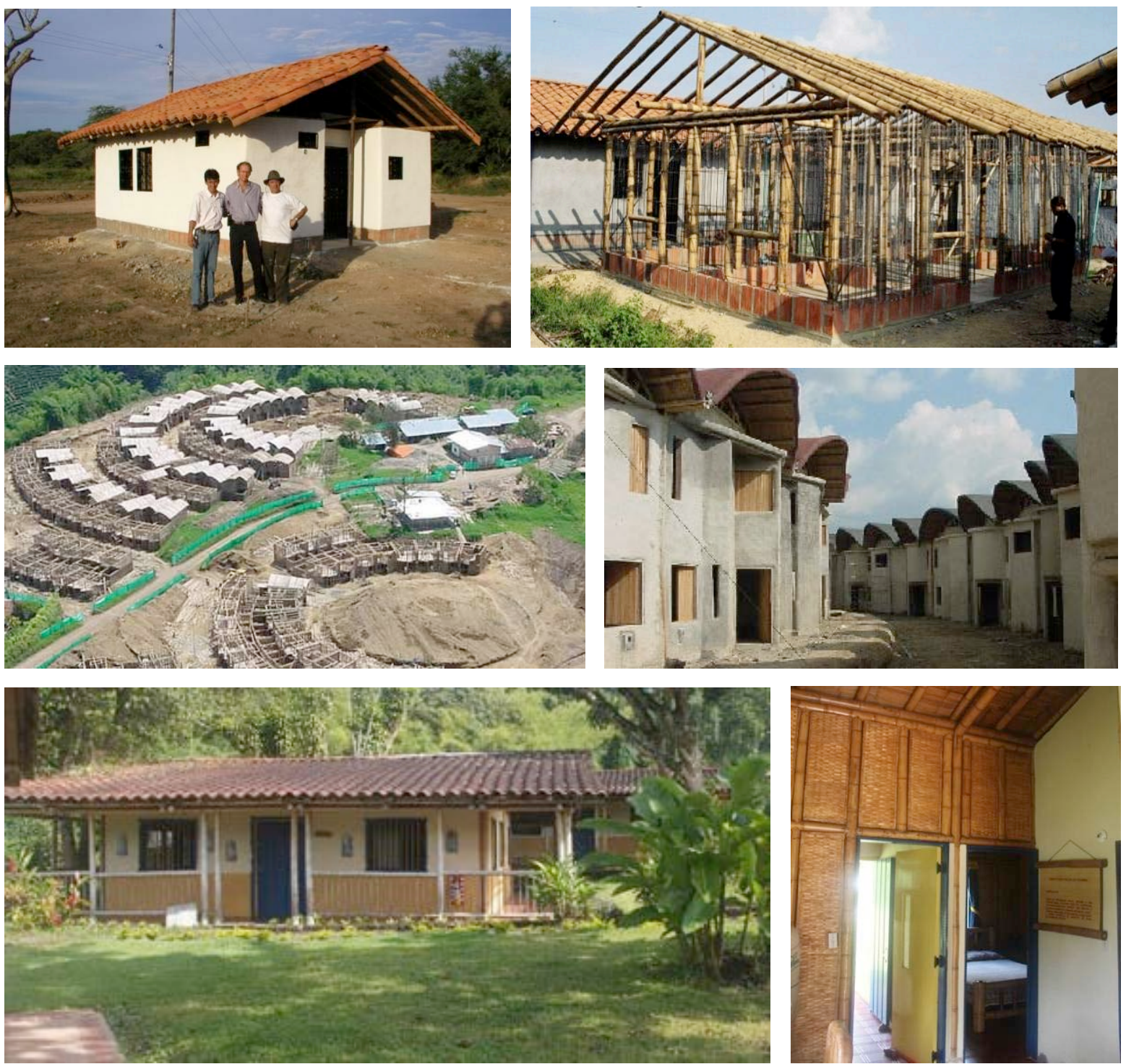

Figuras 97 e 98 - Habitação de Interesse Social em Ricaurte (Simón Vélez), figuras 99 e 100 - Bairro Ciudad

Alegría em Quindío (Opción Timágua) Figuras 101 e 102 - Protótipo Habitação

de Interesse Social (Corporación Autónoma Regional del Quindío - CRQ)

Fonte: acervo pessoal Simón Vélez (97 e 98), http://www. todoarquitectura.com (99 e 100)

e acervo pessoal da autora (101 e 102).

O estudo de caso de alguns exemplos de tais programas/projetos recentemente desenvolvidos em países latino-americanos gera insumos para o desenvolvimento de um sistema construtivo de acordo com demandas específicas do universo de pesquisa em questão, uma vez que muitas das questões inerentes a tais países são aplicáveis em nosso contexto. Foram escolhidos quatro projetos para a análise de seu ciclo produtivo, desde a 
questão do projeto arquitetônico e sua inserção junto à comunidade local até os resultados recentes da pós-ocupação de tais iniciativas. Dentre os principais critérios abordados estão:

- Iniciativa

- Projeto

- Inserção na comunidade

- Produto

- Processo

- Mão-de-obra

- Materiais

- Resultados

Serão analisados, a seguir, quatro casos provenientes de diferentes países da América Latina que contemplam tanto iniciativas públicas quanto privadas, processos participativos quanto à transferência de tecnologia, incluindo ou não processos de capacitação da população local, com maior ou menor escala e relevância no cenário habitacional do país, conforme Tabela 4.

Tabela 4-Casos escolhidos para análise de projetos de habitação de interesse social em bambu.

\begin{tabular}{|c|c|c|c|c|c|c|}
\hline \multicolumn{7}{|c|}{ ANÁLISE PROJETOS DE HABITAÇÃO DE IN] } \\
\hline PROJETOS & INICIATIVA & PROJETO & TECNOLOGIA & EXECUÇÃO & GESTÃO & CAPACITAÇÃO \\
\hline GTZ - COLÔMBIA & público-privada & comunidade & local & comunidade & comunidade & $\operatorname{sim}$ \\
\hline PNB - COSTA RICA & pública & especialistas & transferência de tecnologia & comunidade & comunidade & sim \\
\hline VHC - EQUADOR & privada & especialistas & não há aprendizado técnico & mão-de-obra externa e/ou comunidade & iniciativa externa & não \\
\hline INBAMBU - BRASIL & pública & especialistas & transferência de tecnologia & comunidade & comunidade & sim \\
\hline
\end{tabular}

3.2.3 - Habitações para autoconstrução em Quindío, Colômbia - Cooperação Alemã para o Desenvolvimento (GTZ).

\subsubsection{1 - Introdução}

Dentro do contexto do terremoto de 1999 que afetou mais de 28 cidades da Zona Cafeeira da Colômbia, a Cooperação Alemã para o Desenvolvimento (Deutsche Gesellschaft für Technische Zusammenarbeit - GTZ) em um convênio com a Facultad de Ciencias 
Ambientales da Universidad Tecnológica de Pereira - UTP apresentou uma proposta habitacional em diferentes regiões do departamento de Quindío e Risaralda, visando suprir a demanda do déficit habitacional ocasionado pela catástrofe.

O projeto propôs a reconstrução de habitações camponesas total ou parcialmente destruídas pelo sismo através da autoconstrução, com emprego da mão-de-obra da população afetada e com assessoria técnica permanente desempenhada pelo convênio citado. Os materiais eleitos estavam contidos no universo em questão: a madeira e o bambu guadua. As justificativas fizeram-se tanto pela questão da abundância quantitativa, quanto pelo fato de tais materiais terem apresentado melhor desempenho frente aos abalos sísmicos. Aspectos relacionados às especificações técnicas de construção, adequação de métodos construtivos e informações referentes ao aproveitamento ambiental do manejo das florestas eram tratadas constantemente com a população envolvida no processo. (SALAS 2006)

O projeto representou um ponto de partida para a parceria entre a GTZ e a UTP para a pesquisa de diversos usos do tão abundante recurso local, além de despertar uma atenção especial às culturas construtivas tradicionais dos "campesinos" que há algum tempo haviam sido subjugadas. A boa resposta do material às demandas mecânicas de uma área sísmica desencadeou pesquisas sobre processos de preservação, tratamento, biotecnologia e silvicultura.

Além disso, corporações de toda a Zona Cafeeira (Quindío, Risaralda, Caldas e Valle del Cauca) foram responsáveis pelo desenvolvimento de um plano de manejo sustentável para o uso racional e eficiente das florestas de guadua.

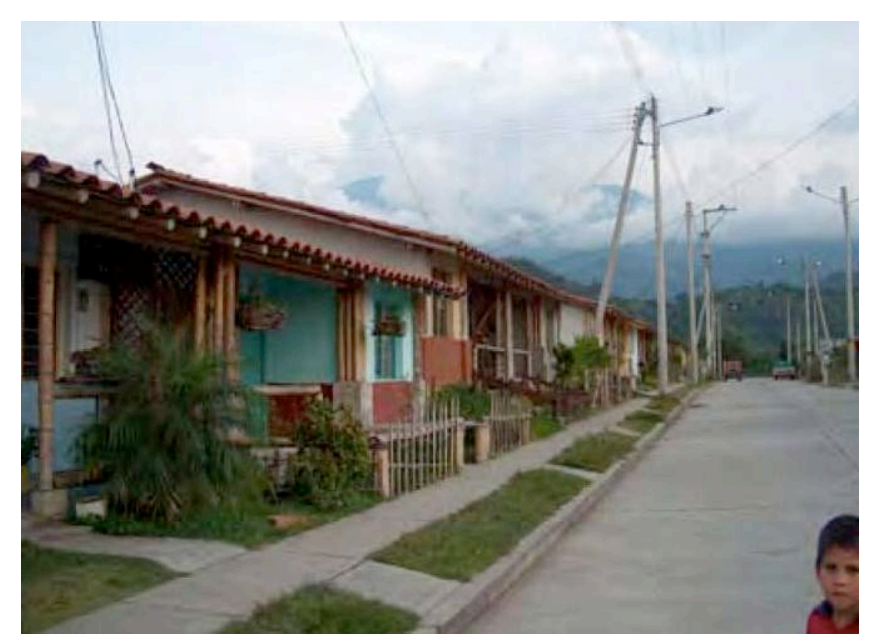

Figura 103 - Bairro El Italiano em Barcelona, Quindío.

Fonte: SALAS 2006 


\subsubsection{2 - Projeto, produto e processo}

O projeto estabelecido pelo convênio visava reunir a maior quantidade de informação técnica para a execução de habitações com estruturas em guadua no regime de autoconstrução. O projeto contou com a participação de órgãos governamentais e nãogovernamentais e resultou na execução de uma cartilha didática com informações acerca do processo construtivo visando uma reconstrução da área afetada de forma consciente, participativa e eficiente (Figura 104).

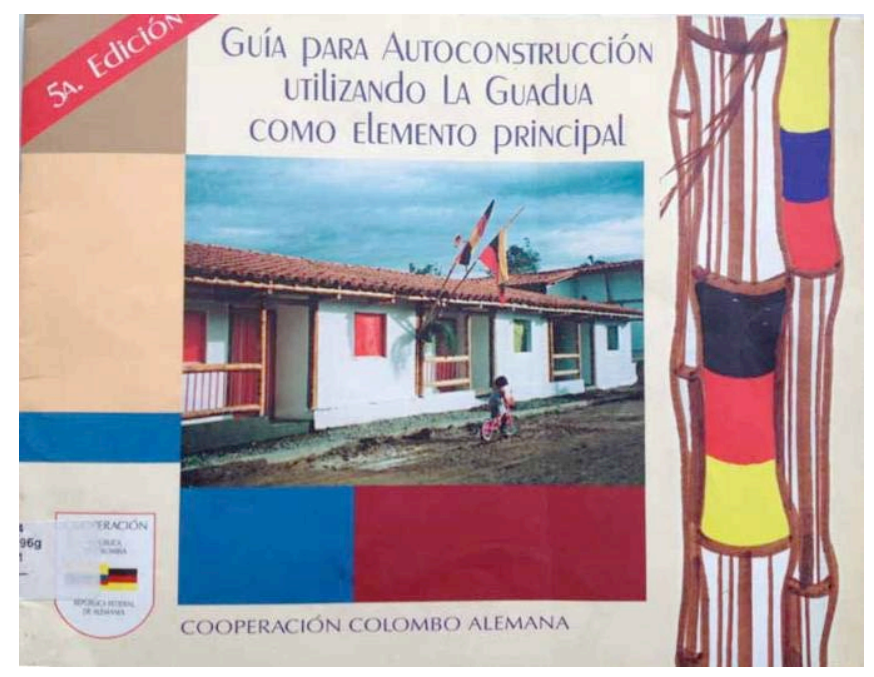

Figura 104 - Cartilha-guia para autoconstrução - cooperação GTZ e UTP.

Fonte: Acervo da autora.

A cartilha apresenta, com uma linguagem simples e objetiva, as técnicas e processos já comumente empregados na região, mas com alguma elaboração sobretudo no tocante às questões que prezam a durabilidade da habitação. O projeto arquitetônico é aberto. Os espaços são definidos de acordo com a necessidade das famílias, sendo difundidas somente as soluções construtivas.

A cartilha prega o processo de tratamento e utilização da guadua para a construção seguindo os seguintes passos:

1. Seleção dos colmos

2. Corte

3. Cura

4. Transporte 
5. Lavagem

6. Imunização

7. Instalação da estrutura

8. Injeção de graute nos locais de maior esforço

9. Proteção às intempéries

10. Manutenção periódica estrutura e cobertura (COOPERACIÓN 2000).

A cartilha inicia a temática dos procedimentos com o processo de tratamento da guadua. Primeiramente, o corte, a ser feito entre o primeiro e segundo entrenó, no período das $23 \mathrm{~h}$ às $6 \mathrm{~h}$, por ser o período no qual a planta não encontra-se em pleno processo de fotossíntese. Após o corte, indica-se o processo de cura na mata, de 15 a 20 dias, dentro da floresta na posição vertical. Dentre os processos de imunização recomendados, constam:

- por imersão: solução de bórax e ácido bórico;

- por injeção: 5 a $10 \mathrm{~cm} 3$ da mesma solução injetados em cada entrenó;

- por defumação: à base de ácido pirolenhoso proveniente da defumação.

Há inicialmente uma recomendação sobre implantação, infraestrutura de água e esgoto e adequação das fundações. As fundações são recomendadas em sapatas corridas de concreto, com arranques de coluna de aproximadamente $15 \mathrm{~cm} \mathrm{X} 15 \mathrm{~cm}$. A estrutura é baseada no sistema viga/pilar com vãos de até $3 \mathrm{~m}$, e suas conexões são as tradicionais boca-de-pescado com barras roscadas metálicas (COOPERACIÓN 2000).

A trama estrutural é composta então por montantes verticais, horizontais e diagonais, que diminuem os vãos das paredes e trabalham o contraventamento da estrutura. Sobre esta trama estrutural de bambus roliços é fixado um plano de esterillas, sobre o qual são fixadas telas metálicas, e argamassadas, conforme a cultura construtiva histórica do bahareque. A cobertura é estruturada através de tesouras de guadua e coberta com telha cerâmica convencional. A proposta da GTZ tem sido constantemente modificada em decorrência dos mais diversos resultados das experiências em comunidades (Figuras 105, 106). 

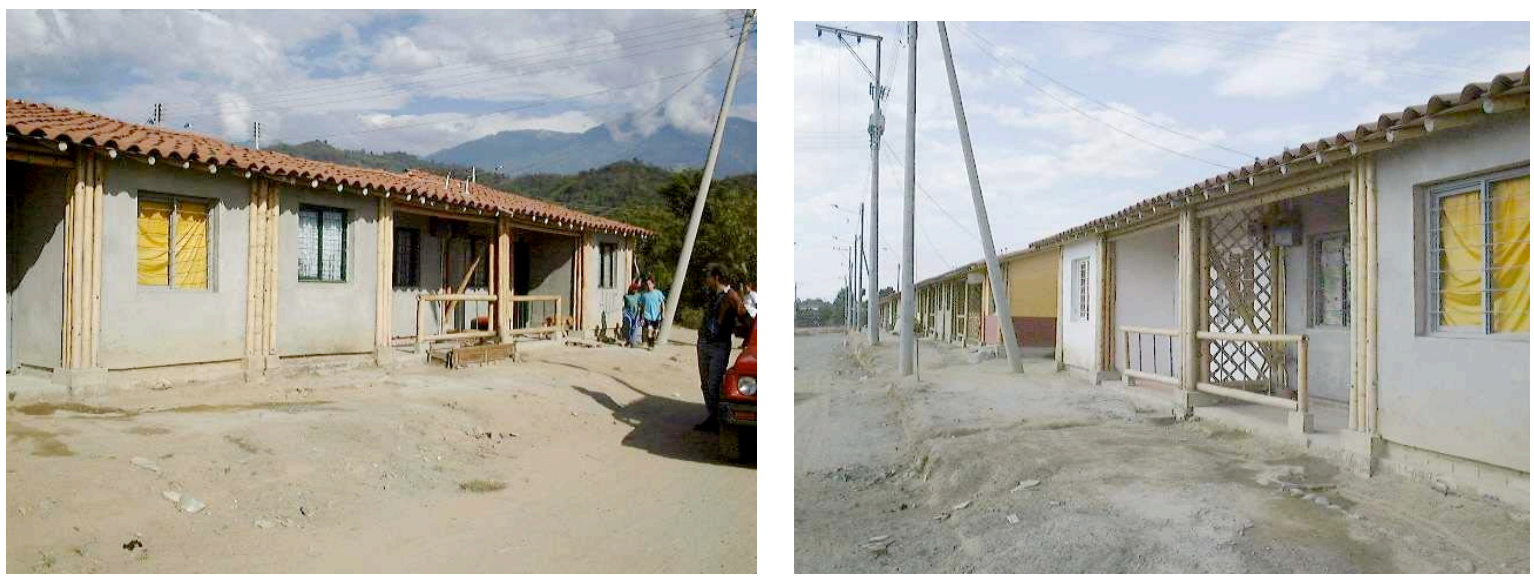

Figuras 105 e 106 - Habitações cooperação GTZ e UTP em construção.

Fonte: STAMN, 2001

\subsubsection{3 - Conclusões}

Há muita discussão acerca das soluções técnicas adotadas no projeto habitacional desenvolvido pela GTZ. Certamente há na utilização do convencional sistema construtivo viga/pilar uma subutilização do potencial estrutural que o material bambu oferece, um superdimensionamento da estrutura e uma acanhada elaboração espacial das habitações, baseadas na solução construtiva indicada na cartilha. No entanto, tais pontos negativos podem ser justificados pela tentativa de utilização de uma linguagem espacial e construtiva já assimilada pela população, que fosse fácil e rapidamente absorvida pelos usuários, para que pudesse sanar os problemas de uma arquitetura emergencial.

Tais fatores estão intimamente ligados com o resgate ao saber construtivo tradicional, e com a autonomia da população afetada em reconstruir sua moradia de uma maneira já conhecida, familiar. A inexistência de um projeto fechado, elaborado por uma outra instância, permite uma maior autonomia das famílias no processo decisório.

Contudo, certamente o principal benefício do projeto remete aos aspectos sociais e políticos nele existentes. A elaboração de uma cartilha, com especificações de materiais, métodos e processos certamente foi fundamental para a solução de um problema local e emergencial. 
3.2.4 - Habitações de Interesse Social em Guayaquil, Equador - Viviendas Hogar de Cristo.

\subsubsection{1 - Introdução}

Fundado em 1973 em Guayaquil, no Equador, o programa Viviendas Hogar de Cristo (VHC) é conduzido por uma organização não governamental católica de serviço social e visa produzir habitação emergencial de baixo custo para famílias com índices sociais muito pequenos. O projeto visa atender à demanda habitacional com a pré-fabricação de habitação composta por elementos construtivos em bambu, vendidas às famílias com preço de custo (TEIXEIRA, 2006).

Com mais de 30 anos de existência, o projeto já foi responsável pela construção de mais de 60.000 casas, devido ao processo evolutivo de racionalização e eficiência na produção em série de seus elementos construtivos pré-fabricados. Além do provimento de habitação, o projeto cristão visa fortalecer a coesão familiar, defendendo a premissa de que ao se criar um abrigo já se está promovendo o início do desenvolvimento econômico e social de uma família. O programa estimula a realização de melhorias nas habitações pelas famílias, e considera a unidade habitacional em bambu o ponto de partida para isso (Figuras 107 e 108).

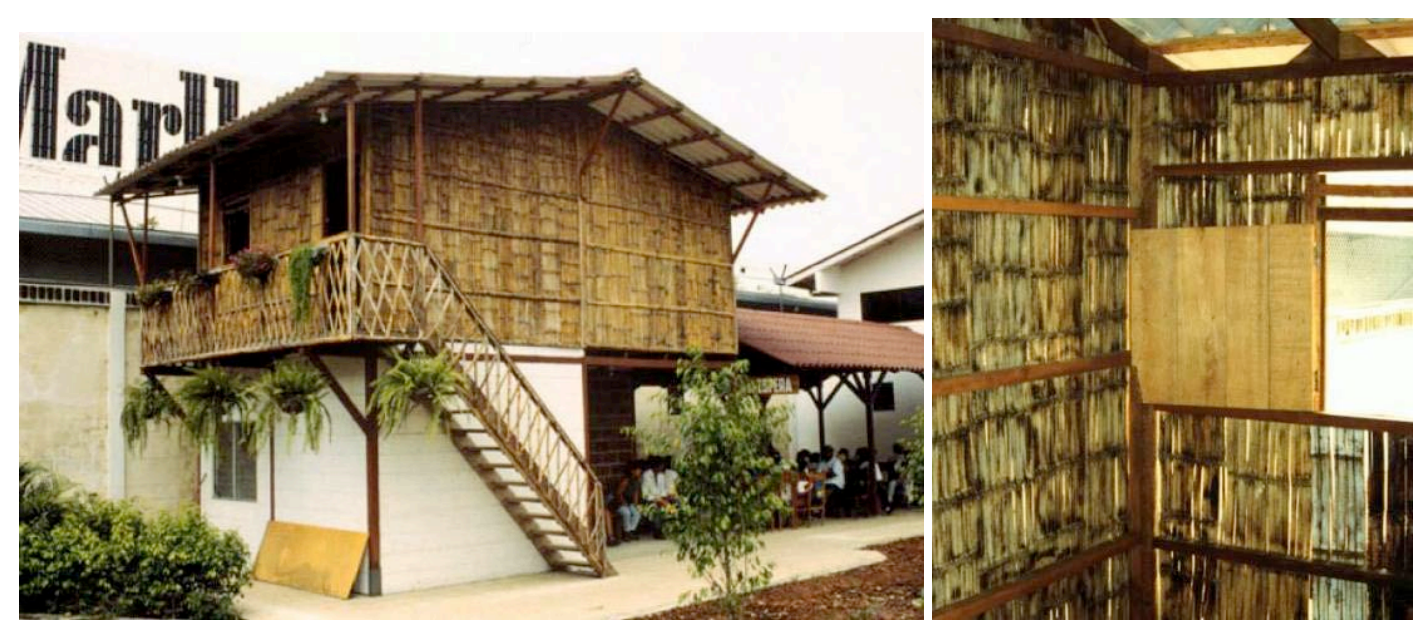

Figuras 107 e 108 - Unidades habitacionais VHC.

Fonte: GUTIERREZ 2000.

\subsubsection{2 - Projeto e produto}

O projeto das casas tem sua tecnologia inspirada nas habitações tradicionais das áreas rurais e das periferias de grandes cidades. Existem três tamanhos-padrão de casa com 
áreas variáveis de 20,5 a $41 \mathrm{m2}$, mas o padrão mais comum é o de único cômodo de formato quadrado. Sua implantação é elevada do solo possibilitando a incorporação de um andar térreo posteriormente. Seu espaço interno é delimitado por uma vedação composta por painéis com estrutura de madeira e vedação em esterillas de bambu. A cobertura é dividida em duas águas com um pequeno balanço.

Toda a casa é pré-fabricada na fábrica da VHC e o kit de componentes é transportado e montado no local. Seu kit básico possui:

- 8 painéis de madeira e bambu para vedação;

- pranchas de madeira para piso;

- uma porta e 3 janelas;

- 9 pilares de madeira;

- telhas de zinco corrugado;

- pequenos componentes metálicos para conexão.
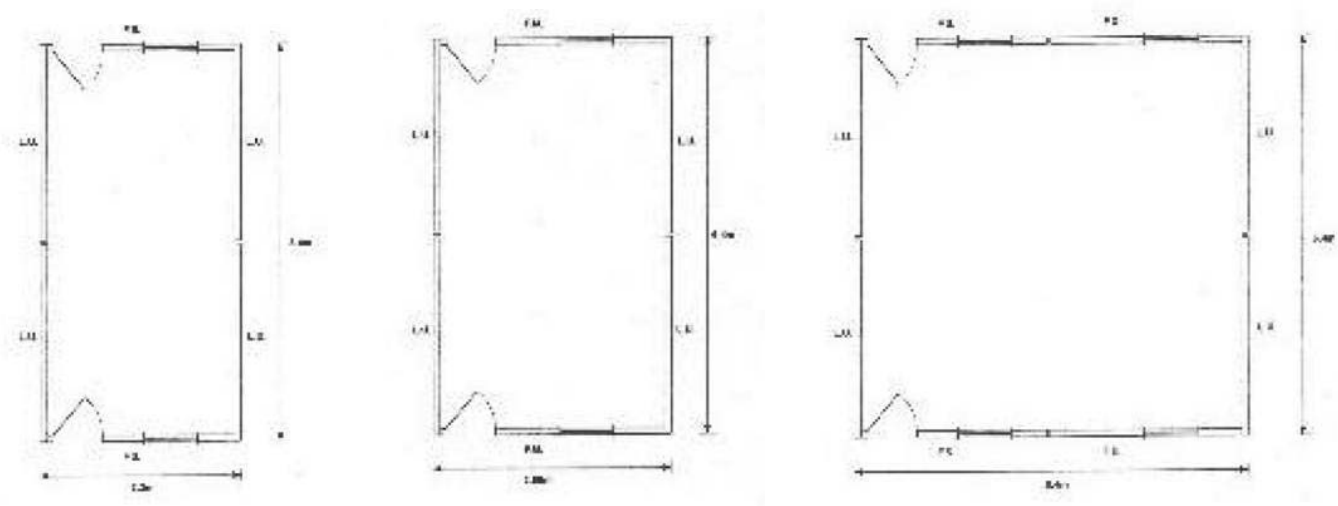

Figura 109 - Variações de plantas do $\operatorname{VHC}(20,5 \mathrm{~m} 2,25,6 \mathrm{~m} 2$ e 41m2)

Fonte: VRIES 2002.

\subsubsection{3 - Processo}

A fábrica VHC que produz de tais habitações de baixo custo é responsável por grande movimentação no setor econômico local uma vez que garante a geração de emprego para elaboração, montagem e transporte dos kits de construção. Uma fábrica responsável pela fabricação de 50 unidades habitacionais por dia necessita da força de trabalho de 150 pessoas (INBAR, 2002). 
O bambu Guadua utilizado é extraído das florestas e diretamente processado com pequenos instrumentos manuais como machadinhas e machados. Já a madeira estrutural é extraída de florestas litorâneas, certificadas por institutos florestais (TEIXEIRA, 2006).

Conforme ilustrado nas figuras 110 e 111, o processo de montagem de painéis é organizado de tal maneira:

1. Montam-se os gabaritos metálicos para definir os diferentes quadros de madeira dos painéis e produzi-los em série;

2. Armazenam-se os materiais de um lado do gabarito, painéis acabados do outro;

3. Fabricam-se os painéis na seguinte ordem:

a. Fazem-se os quadros de madeira;

b. Posiciona-se verticalmente a esterilla e fixa-se a mesma no quadro;

c. Corta-se com serra elétrica o excesso de esterilla.

Em uma jornada de 8 horas de trabalho um operário é capaz de produzir 18 painéis, o suficiente para 3 casas por dia. Em geral, fabrica-se uma casa completa a cada 2,5 horas, o que resulta na já mencionada produção diária de 50 casas (VRIES, 2002).
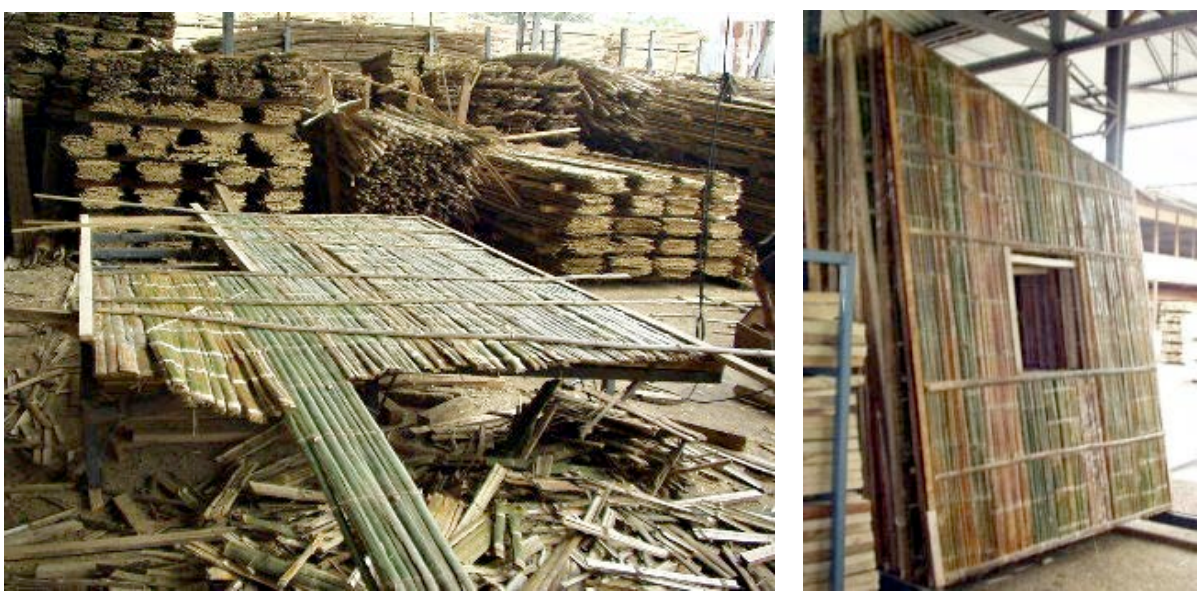

Figuras 110 e 111 - Processo de montagem de painéis Viviendas Hogar de Cristo no Equador. Fonte: PEREIRA; BERALDO 2008.

Ao término da pré-fabricação o kit de componentes é transportado e montado no local através de um manual. Segundo Vries (2002), a casa pode ser montada pelos próprios 
beneficiados ou por consultores técnicos, chegando a ter sua construção finalizada em 4 a 5 horas. Do processo de solicitação até a execução da casa costuma levar de 10 a 15 dias.

O preço inicial de venda das unidades da VHC é de aproximadamente US\$ $385^{21}$, sendo possível a promoção de parcelamento do valor da habitação em até em três anos sem juros, de acordo com a necessidade da família. É importante frisar que os materiais complementares às estruturas e vedações de bambu e madeira como conexões metálicas e telhas de zinco chegam a representar $60 \%$ dos custos totais da casa (VRIES, 2002).

Tabela 5 - Custo da habitação VHC padrão 4,80 m X 4,80 m em dólares americanos (US\$̦).

Fonte: INBAR, 2002

\begin{tabular}{|l|c|c|c|}
\hline ELEMENTOS & QUANTIDADE & PREÇO & TOTAL \\
\hline $\begin{array}{l}2,4 \text { m painél laterais (estrutura em } \\
\text { madeira e vedação em bambu) }\end{array}$ & 4 & 18,32 & 73,28 \\
\hline Painel frontal com janela & 3 & 20,82 & 62,46 \\
\hline Painel frontal com porta & 1 & 18,19 & 18,19 \\
\hline Piso em pranchas de madeira & 1 & 74,44 & 74,44 \\
\hline Cobertura em Zinco & 1 & 105,78 & 105,78 \\
\hline Porta em madeira & 1 & 16,52 & 16,52 \\
\hline Janela em madeira & 3 & 7,88 & 23,64 \\
\hline Embasamento da casa & 1 & 35,20 & 35,20 \\
\hline Sub-total materiais & & & 409,52 \\
\hline & & & \\
\hline Mão de obra & & & 14,44 \\
\hline Custos fixos da fábrica & & & 26,05 \\
\hline & & & \\
\hline Custo total & & & 450,00 \\
\hline
\end{tabular}

O desempenho da habitação em relação a terremotos é satisfatório por se tratar de uma estrutura leve. Por estar elevado do solo, o bambu está protegido da ação de fungos, umidade e calor. As paredes possuem aberturas na própria constituição da esterilla, o que permite uma boa ventilação. No entanto, a cobertura em telhas de zinco certamente representa um ponto muito negativo em relação ao conforto térmico da unidade.

\footnotetext{
${ }^{21}$ De acordo com INBAR (2002), dados mais atualizados consideram esse valor como US\$ 450,00.
} 


\subsubsection{4 - Conclusões}

O projeto VHC é considerado bem sucedido por corresponder à uma demanda habitacional muito latente no contexto equatoriano de uma maneira produtiva e econômica. Dentre seus principais pontos positivos relacionados à cada aspecto, podem ser citados:

1. Aspectos de produção:

- criação de oportunidade de emprego para população na manufatura;

- criação de oportunidade de emprego para população rural na produção de bambu;

- necessidade de pequeno investimento inicial;

- simplicidade de equipamentos necessários no processo produtivo;

- racionalização da produção pela pré-fabricação e pouco desperdício de material;

- simplicidade da produção possibilita o funcionamento da fábrica independentemente do tamanho da demanda.

2. Aspectos ambientais:

- intensifica o cultivo do bambu e estimula a reabilitação de florestas degradadas;

- promove uma boa gestão do uso do bambu;

- configura um processo de construção não poluente.

3. Aspectos beneficiados:

- provisão de uma habitação resistente;

- uso de materiais locais;

- baixo custo de transporte;

- facilidade e rapidez na montagem.

Além desses aspectos, o projeto também obteve êxito por uma boa adaptação social com os habitantes e por uma boa acomodação no contexto construtivo local.

Quanto aos pontos negativos do projeto habitacional VHC, deve-se levar em consideração que este tem como prerrogativa a formação de um abrigo provisório e inicial, que vise futuras modificações para uma habitação definitiva e digna. No entanto, pelo que o programa vem mostrando, grande parte das edificações não sofrem melhoramento em suas 
condições, e muitas vezes não recebem nem mesmo algum tipo de manutenção, o que faz com que o projeto desencadeie uma série de habitações precárias permanentes.

Outra questão importante é que não há um plano efetivo de manejo do bambu e de madeiras a serem utilizadas, e dada a enorme demanda na região por esse tipo de habitação, é necessário rever planos de reflorestamento de bambu e de árvores afim de garantir o suprimento de matérias-primas e a não-degradação do ambiente natural das regiões onde se atua. Uma solução do ponto de vista social pode significar um desastre ambiental irreversível.

Além disso, faz-se necessária a revisão do projeto, uma vez que este contempla apenas um abrigo, e não especifica áreas molhadas, infraestrutura de sistemas, etc.

\subsection{5 - Habitações Projeto Nacional de Bambu na Costa Rica \\ 3.2.5.1 - Introdução}

Concebido em 1986 na Costa Rica, o Proyecto Nacional del Bambú (PNB) possuiu como objetivo principal atender às demandas geradas pela crise habitacional no país, sobretudo em zonas rurais de baixa renda. Além de prover habitações econômicas à tal população, o projeto visou estimular a geração de trabalho baseado em recursos locais sem a degradação do meio-ambiente, preservando os recursos florestais locais e associando o uso do bambu à promoção de um desenvolvimento social e econômico.

A organização do projeto foi uma iniciativa do Governo da Costa Rica através do Ministerio de Vivienda y Asentamientos Humanos (MIVAH) em San Jose, administrado pelo United Nations Development Programme (UNDP) e financiado pelo Governo dos Países Baixos e pelo Banco Centro Americano de Integração Econômica (BCID). Em Julho de 1995, o projeto deu origem à Fundación del Bambú (FUNBAMBU) com a tarefa de administrar o programa como um todo, garantindo a continuidade dos trabalhos desenvolvidos até então, e a afirmação da matéria-prima bambu.

Segundo Vries (2002), o projeto possuía três principais objetivos:

- Construção de 760 unidades habitacionais modelo em bambu em 38 comunidades rurais do país, em um programa de auxílio à construção de 7500 casas por ano no setor rural;

- Cultivo de 700 hectares de bambu Guadua para garantir material para o futuro do programa; 
- Capacitação de mais de 1000 profissionais, técnicos e chefes de família para os métodos de cultivo, produção e preservação de bambu para uso na construção civil.

O projeto desenvolveu-se em três fases. Primeiramente, uma fase preparatória, de apresentação de uma cultura construtiva à uma população que até então desconhecia tal prática. Nesta fase desenvolveu-se um projeto-piloto baseado em experiências construtivas de países como Colômbia e Equador, dentre elas o bahareque. Nas fases seguintes, a implementação do projeto em áreas rurais foi realizada, com atividades de treinamento técnico, cultivo massivo do bambu, organização dos trabalhos, avaliações ambientais de tecnologia e produção de mobiliário (Figuras 112 e 113).

Assim, o projeto alcançou importantes metas, como:

- desenvolvimento de uma tecnologia de construção que permitiu atender aos setores mais necessitados do país;

- desenvolvimento de uma tecnologia para a elaboração de tramas de bambu, uteis para a elaboração de painéis;

- desenvolvimento de uma fábrica de painéis de bambu que permitem produção em série, barateando e otimizando a produção;

- desenvolvimento de uma fábrica de protótipos de móveis em bambu.
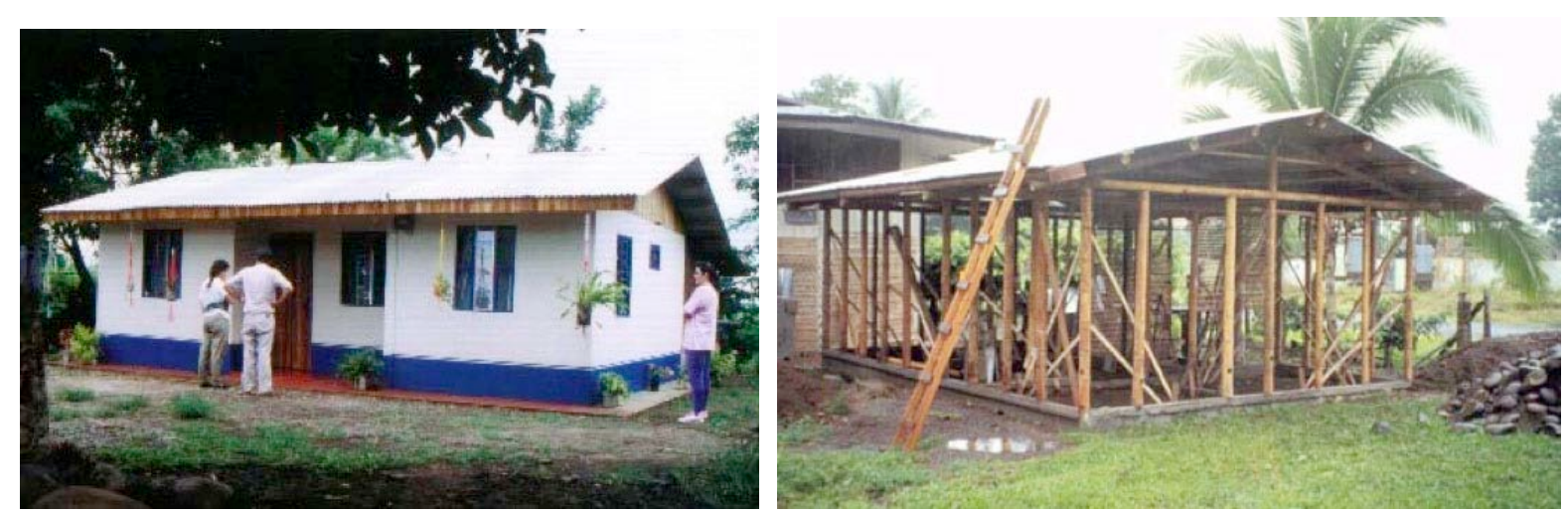

Figuras 112 e 113 - Unidades habitacionais-modelo PNB.

Fonte: GUTIERREZ 2000. 


\subsubsection{2 - Projeto e produto}

A construção das casas do PNB foi composta sobretudo por materiais como o bambu (Guadua spp.), caña brava (Gynerium spp.) e madeira. As habitações desenvolvidas possuem uma tipologia térrea, de planta retangular com aproximadamente $45 \mathrm{~m} 2$ de área. A cobertura é dividida em duas águas com um pequeno balanço. A estrutura desenvolvida é otimizada, compondo-se em 20 peças de bambu de um mesmo comprimento e seis conexões de metal idênticas.

A aparência final da habitação uma vez rebocada é a de uma casa em alvenaria nos padrões convencionais. As fundações são feitas por uma viga baldrame e uma fileira de blocos de concreto é assentada para garantir o isolamento da parede de bambu do solo.

A vedação é composta por 17 painéis pré-fabricados de bambu e madeira, com acabamento em reboco de argamassa de cimento. O bambu utilizado para vedação foi trabalhado em forma de esterilla de Guadua e caña brava, um bambu de aproximadamente $2,5 \mathrm{~cm}$ de diâmetro. A fixação foi feita com grampos e pregos, e por arame galvanizado, no caso da união da esterilla. A argamassa utilizada é uma mistura de areia e cimento e é aplicada nos dois lados do painel, com uma espessura de $2 \mathrm{~cm}$, formando um painel diafragma capaz de eliminar a necessidade de elementos diagonais. Vries (2002) afirma que as paredes elaboradas pesavam $100 \mathrm{~kg} / \mathrm{m} 2$, o que representa $35 \%$ do peso de uma parede em bloco de concreto (Figura 114).
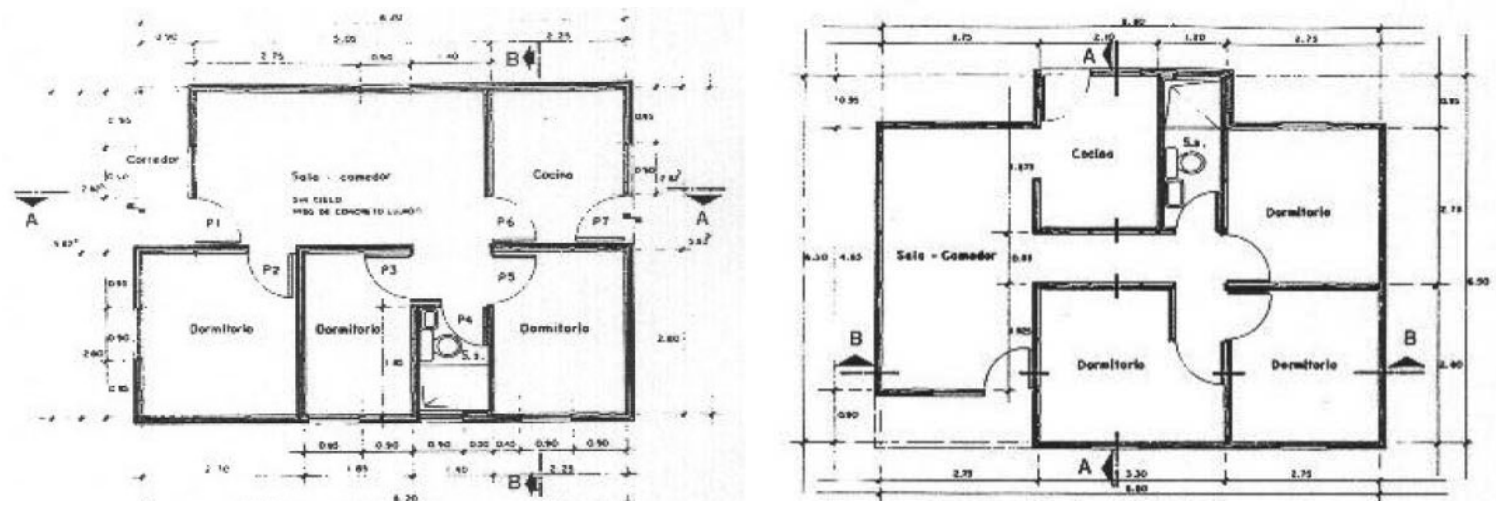

Figura 114 - Variações de plantas de PNB.

Fonte: VRIES 2002.

Quanto à questão estrutural, o projeto dedicou atenção especial às propriedades físico-mecânicas do bambu a ser utilizado na construção, uma vez que ela estaria situada em uma área de grande risco sísmico. De fato, em 1990 as casas sofreram um sismo nas regiões de Cobano, Puriscal e Limón, onde 30 casas (mais de $50 \%$ das casas construídas) não sofreram danos diante do sismo de 7.6 pontos na escala Richter (JANSSEN, 1995). 

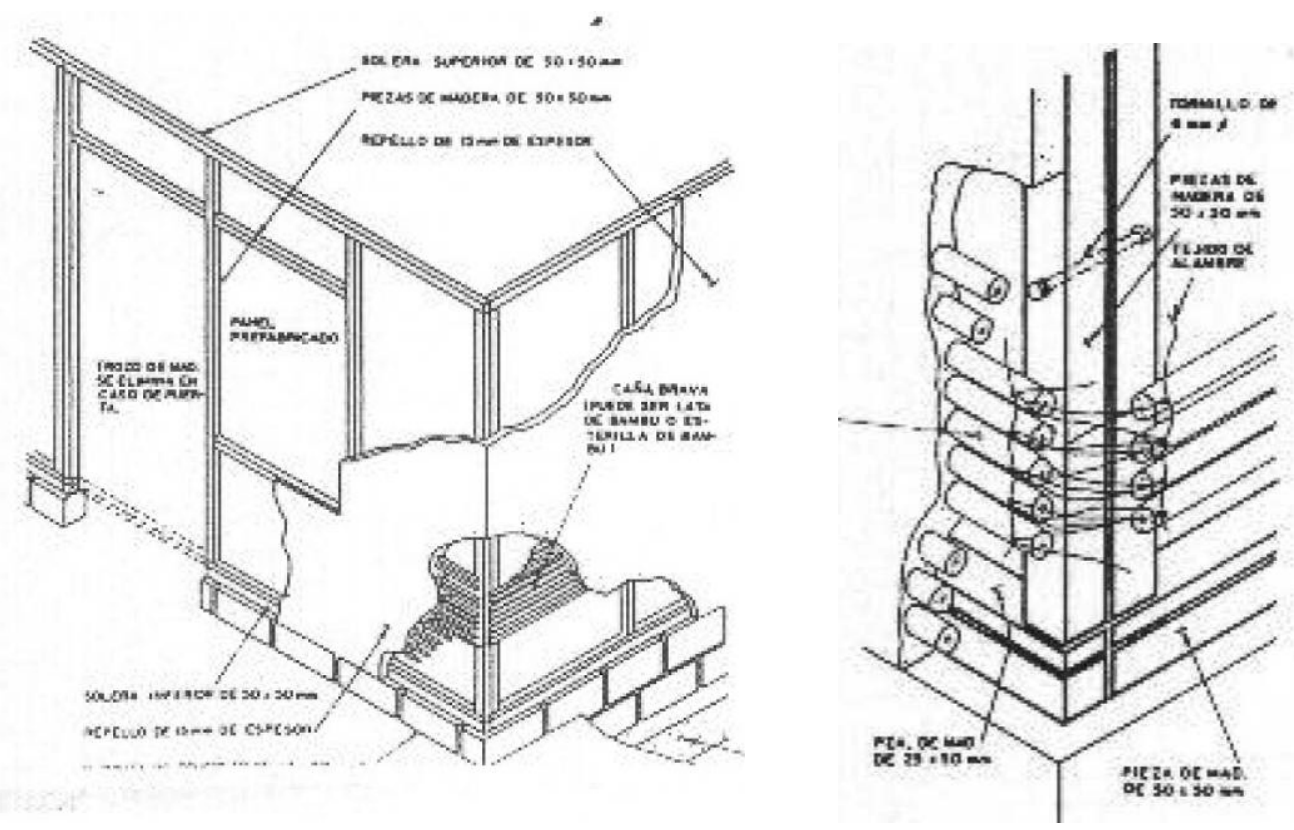

Figuras 115 e 116 - Detalhes vedação composta por painéis diafragma.

Fonte: VRIES 2002.

\subsubsection{3 - Processo}

Segundo Janssen (1995), a mão-de-obra para a execução das casas foi composta pelos próprios moradores mediante treinamento técnico baseado nos métodos de construção com ajuda mútua. Dessa forma, o projeto desenvolveu um processo de formação junto às famílias não somente focado em questões técnicas e construtivas mas também nos benefícios da organização comunitária. Assim, o envolvimento das famílias ultrapassou os limites da construção da casa própria, estimulando e motivando os envolvidos ao engajamento em ações de melhoria da vizinhança, como o aperfeiçoamento das redes de infraestrutura pública.

Quanto ao treinamento técnico, tanto o material quanto a cultura construtiva do bambu representaram um vocabulário novo para a população da Costa Rica. Sendo assim, conforme já mencionado, o processo de treinamento técnico foi uma das prioridades do projeto em sua fase preparatória. Ao final de tal estágio, em 1991, 400 famílias e 60 técnicos foram treinados sobre os temas: cultivo e manutenção da plantação, tratamento e secagem do material e construção de mobiliários e habitações, além de conceitos sobre organização comunitária e administração de pequenas propriedades rurais. Paralelamente à produção, um centro de pesquisa e desenvolvimento foi criado para garantir o aprimoramento de questões de tratamento como secagem e imunização através do método Boucherie e a prática de medidas de controle de qualidade. 
O tipo de trabalho exigido na produção das unidades do PNB é de baixa complexidade construtiva, fazendo com que o projeto atenda o principal requisito: o da autoconstrução. Os equipamentos utilizados no processo construtivo eram sobretudo ferramentas de mão, exceto pela betoneira. Entretanto, algumas tarefas do processo eram mais complicadas e demandavam uma qualificação específica, como é o caso do assentamento de blocos, acabamentos e instalações.

Assim, as casas construídas em ajuda mútua obedeciam um processo evolutivo que se desenvolveu em torno de etapas detalhadas na Tabela 6 . 0 tempo médio estimado para a construção de uma unidade habitacional é de 45 dias.

Tabela 6 - Fases do processo de produção do PNB.

Fonte: $P N B^{22}$ (apud VRIES, 2002).

\begin{tabular}{|l|c|}
\hline FASE & TEMPO (DIAS) \\
\hline 1. Preparação do solo & 2 \\
\hline 2. Fundação & 5 \\
\hline 3. Pré-fabricação de painéis & 4 \\
\hline 4. Instalação dos painéis & 1.5 \\
\hline 5. Estrutura do telhado e acabamentos & 3 \\
\hline 6. Acabamento vedação & 8.5 \\
\hline 7. Instalações hidráulicas & 0.5 \\
\hline 8. Piso & 4 \\
\hline 9. Caixilhos & 5 \\
\hline 10. Instalações de esgoto & 1 \\
\hline 11. Instalações elétricas & 4 \\
\hline 12. Fossa séptica e drenagem & 3 \\
\hline 13. Acabamentos finais & 3 \\
\hline \multicolumn{2}{|l}{} \\
\hline Tempo total de construção & 44.5 \\
\hline
\end{tabular}

Uma das formas de organização do processo construtivo deu-se através da préfabricação de painéis. De acordo com Cardoso (2000), foi montada em Limón a estrutura de uma fábrica de painéis com o intuito de produzir uma média de 10 unidades habitacionais por semana. E para corresponder aos anseios da grande demanda habitacional do país, o governo estabeleceu alguns critérios para a implementação dessas fábricas, dentre eles:

- proximidade de plantações de bambu;

\footnotetext{
${ }^{22}$ Proyecto Nacional de Bambu (1993). Paquete tecnologico construcción, version 1.
} 
- estrutura viária de fácil escoamento da produção bem como fácil provimento de matéria prima;

- proximidade da demanda habitacional.

Segundo Bambusetum ${ }^{23}$ (apud CARDOSO, 2000), tais fábricas deveriam contar com:

- 400 m2 de área coberta para produção;

- 700 m2 para armazenamento de matéria-prima e produtos prontos;

- $100 \mathrm{~m} 2$ para armazenamento de produtos químicos;

- 50 m2 para administração.

Já em relação ao custo das unidades habitacionais calculado no projeto, estimou-se que o $\mathrm{m} 2$ construído representava o valor de US\$100,00, fazendo com que a unidade de 40 $\mathrm{m} 2$ custasse aproximadamente US\$ 4.000,00. O projeto influenciou a gestão política local pela construção de casas com um custo de, aproximadamente, $20 \%$ inferior ao das casas convencionais.

\subsubsection{4 - Conclusões}

O PNB possui como grande atributo sua abordagem integrada, completa e de vanguarda. Abarcou de uma maneira convicta questões como a transferência tecnológica da cultura construtiva do bambu, a articulação da organização comunitária, o manejo e proteção do ambiente natural local e a formação de uma mão de obra e de uma atividade produtiva no local. O consciente projeto arquitetônico baseou-se na adequação de desenho aos recursos materiais disponíveis, trazendo à atividade construtiva valores mais econômicos, e viabilizando assim o projeto em nível nacional, consolidando a FUNBAMBU na Costa Rica.

É inegável mencionar a dimensão que o projeto alcançou com um investimento relativamente baixo. A verba composta por fundos nacionais e internacionais investiu na aquisição de equipamentos, no treinamento de pessoas e na pesquisa, conseguindo promover substanciais benefícios sociais, econômicos e ambientais a longo prazo.

O projeto foi catalogado como uma das 100 melhores práticas na conferência HABITAT II em Istambul em 1996, e em 1998 Costa Rica foi a sede do V Congresso Internacional de Bambu, pela primeira vez realizado fora do continente Asiático.

\footnotetext{
${ }^{23}$ BAMBUSETUM (1992) Boletin Informativo de la Fundación Nacional de Bambu. Costa Rica, Nov., 7p.
} 
É necessário considerar alguns pontos controversos sinalizados por muitos envolvidos no processo no PNB como, por exemplo, a adaptação da população ao processo de transferência tecnológica. Por ser uma tecnologia totalmente desconhecida na Costa Rica, o projeto enfrentou no princípio uma certa resistência nas comunidades beneficiadas. Além disso, o projeto que baseava-se na mão de obra exclusivamente local, demonstrou-se de maior complexidade, demandando muitas vezes algumas habilidades profissionais específicas.

Pode-se concluir que no geral, o PNB representou um processo bem-sucedido, que com custo relativamente baixo resolveu muitas das questões pertinentes ao déficit habitacional de países em desenvolvimento. Dessa forma, o projeto atraiu diversos interessados em seu processo, tendo repercussão internacional, sobretudo dentre os países latino-americanos, devido à similaridade socioeconômica que os une.

\subsection{6 - Habitações de Interesse Social em Alagoas, Brasil - Instituto do Bambu.}

\subsubsection{1 - Introdução}

Talvez o mais expressivo projeto relacionado à habitação de interesse social realizado no Brasil foi o desenvolvido na comunidade de Juvenópolis, em Alagoas, em 2003. Tratou-se de um projeto arquitetônico desenvolvido pelo arquiteto Rubens Cardoso e pelo engenheiro Edson Sartori, desenvolvido pelo Instituto do Bambu (INBAMBU), um centro de capacitação e pesquisa sobre o uso do bambu, envolvendo a comunidade, professores e alunos da Universidade Federal de Alagoas (UFAL).

O projeto foi baseado no regime de mutirão dos habitantes da comunidade em todo processo produtivo: da extração da matéria-prima até os acabamentos finais da obra construída. Foi executado um protótipo da habitação, posteriormente doada a um dos moradores da comunidades participante do processo. Após ser concluída, a habitação foi por dois anos objeto de estudo de alunos de pós-graduação da UFAL para uma análise sobre o bambu como material de construção e para uma Avaliação Pós-ocupação (APO) da habitação desenvolvida. Uma vez o protótipo em uso por um dos moradores da comunidade, elaborou-se um estudo avaliando a relação ambiente e usuário (Figuras 117 e 118). 

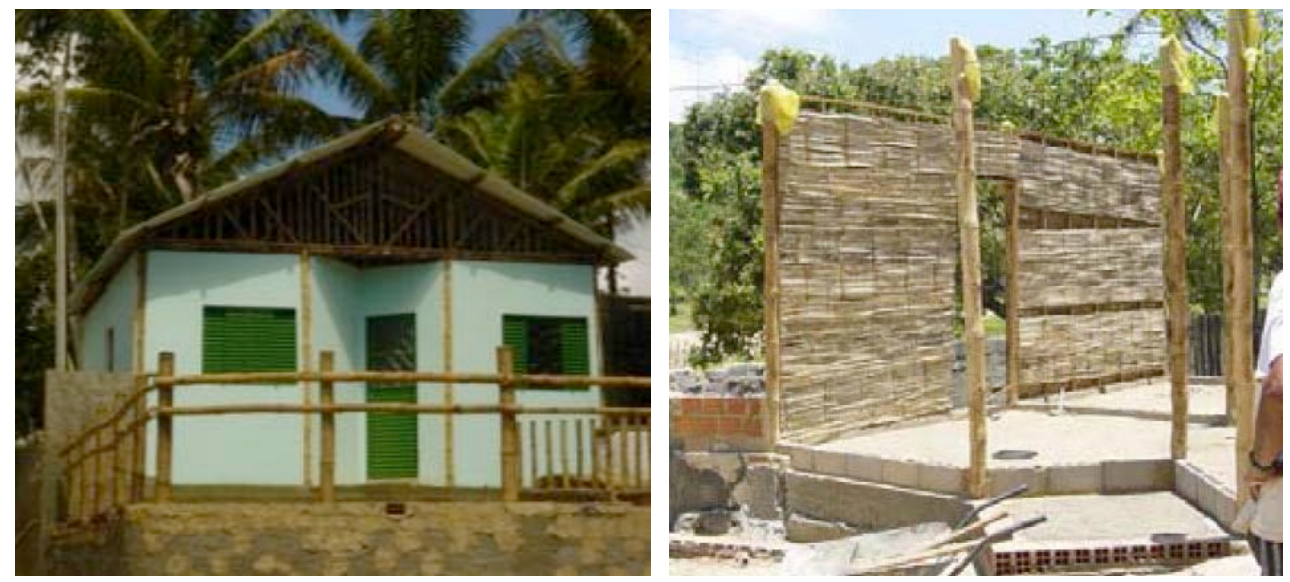

Figuras 117 e 118 - Habitação de interesse social em Maceió.

Fonte: OLIVEIRA 2006 (117) e Acervo pessoal Arq. Rubens Cardoso Jr (118).

\subsubsection{2 - Projeto e produto}

A escolha do material bambu deu-se pela disponibilidade do mesmo no Parque da Cidade, em Alagoas, região onde encontra-se grande quantidade da espécie Bambusa vulgaris, que apesar de possuir muito amido em sua composição, foi a espécie trabalhada por ser encontrada em abundância.

Conforme figura 119, a habitação projetada é térrea e unifamiliar; a geometria de sua planta é quadrada, composta por: sala, cozinha, banheiro, dois dormitórios e um terraço, com uma área construída de aproximadamente $38 \mathrm{~m} 2$. A técnica construtiva utilizada foi baseada na cultura construtiva colombiana das esterillas como forma de vedação, trazendo maior conforto térmico pelo isolamento formado pelo colchão de ar entre as esterillas (SILVA et al., 2008).

Os acabamentos das vedações foram em reboco de cimento, do piso em cimento queimado, e da cobertura em telha de fibrocimento pintada. As esquadrias utilizadas foram as industrializadas de chapa de alumínio pintada. 


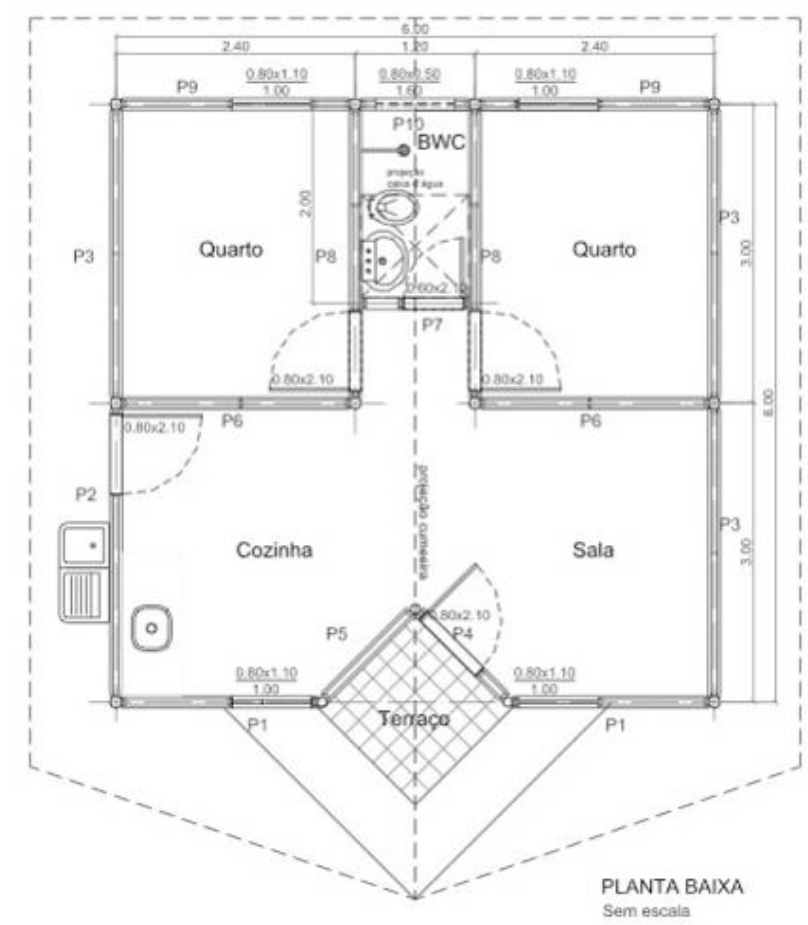

Figura 119 - Planta Projeto INBAMBU em Alagoas.

Fonte: SILVA et al., 2008.

\subsubsection{3 - Processo}

O processo de execução do protótipo foi feito entre o INBAMBU, alunos e professores da UFAL e 12 famílias da comunidade local, sendo estas representadas por no mínimo duas pessoas de cada família. O processo foi de transferência tecnológica sobre o manejo do material, já que nunca haviam trabalhado o bambu para fins construtivos. A partir de palestras, conversas e atividades entre os envolvidos, pouco a pouco o sistema construtivo foi sendo absorvido, bem como as informações inerentes à extração e tratamento da matéria-prima.

O corte do colmo foi racionalizado, relacionando as partes do colmo com os usos destinados, e aproveitando-o em toda sua extensão. A base, de maior espessura e maior extensão, foi utilizada na elaboração dos pilares e vigas. A parte intermediária, com aproximadamente $3 \mathrm{~m}$ de comprimento foi utilizada na confecção de esterillas. Já a parte superior foi utilizada na elaboração de ripas para a composição de treliças para o telhado.

O tratamento empregado foi a substituição de seiva vertical, onde o bambu recém cortado tem sua base envolvida por um saco plástico contendo uma solução aquosa de 0,1 a 
2,0\% de óleo emulsionado de extrato de $\mathrm{Nim}^{24}$ e é deixado por aproximadamente 15 dias, para que ocorra a distribuição do $\mathrm{Nim}$ da base até as folhas. Os pilares, após esse tratamento, também foram submetidos à cura pela chama.

Iniciou-se então o processo de fabricação de esterillas, confeccionadas com instrumentos simples como facões, machados e marretas. Após abertas e limpas as esterillas passaram pelo processo de secagem à sombra. A fundação foi executada com sapatas corridas de concreto armado, localizadas sob as paredes. Após a execução do baldrame com blocos de concreto, foram locados os pilares e na sequência, com base nas medidas reais, foram confeccionados os painéis.

Os painéis de vedação foram confeccionados com esterillas amarradas com arame e pregadas nos dois lados de um quadro de madeira, formando um painel oco. O quadro foi formado por madeiras de seção comercial $5 \mathrm{~cm} \mathrm{X} 3 \mathrm{~cm}$. Houveram algumas aberturas previstas para a passagem de instalações, que aconteciam no espaço interno do painel. $A$ fixação dos painéis com os pilares foi feita por meio de parafusos (Figuras 120 e 121).

O revestimento dos painéis foi feito com argamassa, sendo a aderência garantida pela parte interna do bambu em forma de esterilla voltada para fora, a aplicação de chapisco anteriormente e a argamassagem de baixo para cima. O processo completo, do treinamento junto à comunidade até a execução durou 6 meses. O protótipo em si teve sua execução no tempo de dois meses. Após um ano e meio de uso, a casa passou pela avaliação pósocupação anteriormente citada (SILVA et al., 2008).
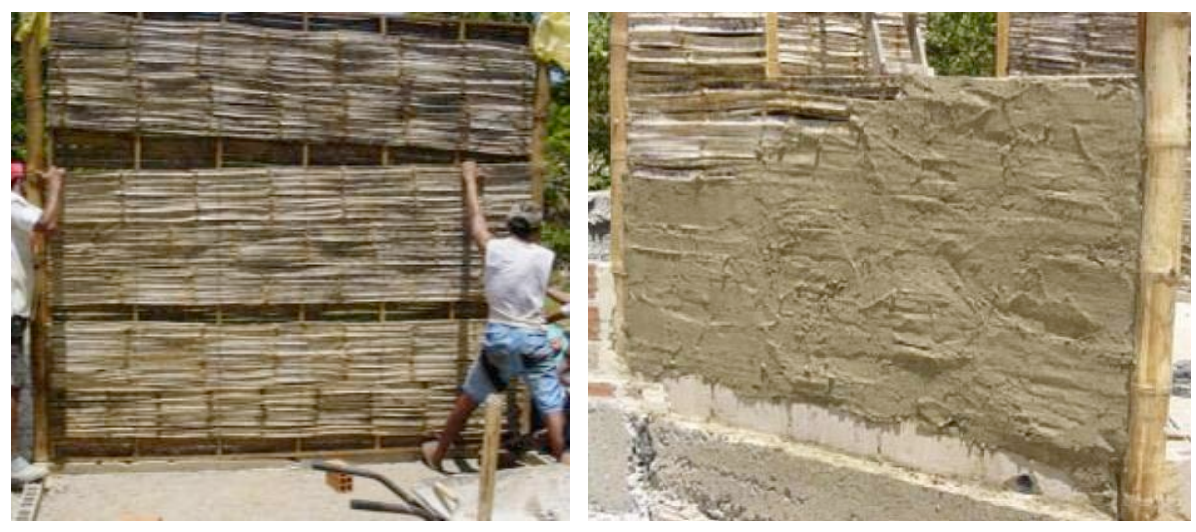

Figuras 120 e 121 - Processo de pré-fabricação de painéis e argamassagem do painel fixo.

Fonte: OLIVEIRA 2006 e Acervo pessoal Arq. Rubens Cardoso Jr.

\footnotetext{
${ }^{24}$ O Nim (Azadirachta indica) é uma planta natural do sudeste da Ásia e do subcontinente indiano. Atua sobre alguns fungos e bactérias, sendo frequentemente usada como pesticida.
} 


\subsubsection{4 - Conclusões}

A experiência de Alagoas, de uma maneira geral representou a incursão de um novo material com relativa simplicidade na concretização de uma habitação satisfatória, e contribuindo para o barateamento da obra e para a não agressão ao meio ambiente. 0 sistema representou uma grande simplicidade construtiva que pode ser facilmente compartilhada com a comunidade.

No entanto, a avaliação pós-ocupação feita com a unidade construída apontou alguns aspectos negativos esboçados pelo projeto após um ano e meio de uso. Primeiramente houve um descontentamento em relação ao material empregado na técnica construtiva no que diz respeito à sua preservação. $O$ tratamento utilizado não foi suficientemente preservativo, sendo que o bambu sofreu o ataque de brocas ${ }^{25}$. 0 método preservativo utilizado estava ainda sendo testado em uma pesquisa e tal fato deve ser corrigido em próximas ações relacionadas ao tratamento do material.

Outro ponto de descontentamento observado na avaliação foi em relação à questões de projeto, sobretudo à estanqueidade. A treliça da cobertura, vedada somente com tela permitia a passagem de poeira e de chuva ao interior. A falta de isolamento acústico também foi apontada como inconveniente. Essas questões podem ser solucionadas com pequenas intervenções de projeto.

Vale lembrar que a edificação foi sinalizada como não recebendo uma manutenção adequada, sobretudo na conservação do revestimento, fato este que pode interferir na conservação dos materiais. Por outro lado foi constatado nos moradores um grande contentamento no uso da casa. Em relação à aparência da casa e aos materiais empregados, não houve estranhamento do usuário com o material bambu. Além disso, questões como dimensionamento dos espaços, iluminação e ventilação tiveram boa avaliação de satisfação do usuário.

Assim, mapeados os principais problemas e corrigidas algumas questões de projeto, pode-se afirmar que o bambu representa um possível material para uso na construção civil, inclusive para suprir a carência de habitação de interesse social no Brasil. Representa uma fonte abundante de matéria-prima que pode, segundo Silva et al. (2008), reduzir em até $40 \%$ o custo de uma obra executada com métodos tradicionais ${ }^{26}$. É necessário, no entanto, um trabalho de formação e de conscientização sobre as características dos materiais para que o

\footnotetext{
${ }^{25}$ Broca ou caruncho, nome popular para o inseto xilófago Dinoderus minutus.

${ }^{26}$ Conforme verificado na execução do protótipo, a técnica construtiva desenvolvida foi relacionada à técnica de alvenaria cerâmica convencional utilizada comumente na região (SILVA et al., 2008).
} 
domínio desses conhecimentos específicos contribua para uma boa utilização do material e para a consolidação de uma cultura construtiva bem empregada. 
CAPÍTULO 4 - PROTÓTIPO DE SIMULAÇÃO CONSTRUTIVA 
4.1 - Sistemas construtivos em bambu: Possibilidades de desenvolvimento no Vale do Ribeira

\subsection{1 - Premissas para elaboração do projeto}

\subsubsection{1 - Introdução}

Partindo da revisão bibliográfica desenvolvida no Capítulo 2 sobre sustentabilidade no contexto do Vale do Ribeira, SP, chegou-se à um compêndio de informações desde técnicas até sociais, baseadas no contato direto com o universo em questão. O objetivo do levantamento de tais dados é a geração de insumos para a realização de um projeto arquitetônico e de um sistema construtivo que represente uma possível alternativa de solução construtiva habitacional no contexto das comunidades caiçaras e ribeirinhas. Devese deixar claro que tal proposta não representa uma solução à questão habitacional local do ponto de vista tecnológico, mas sim representa uma primeira aproximação do que pode ser uma alternativa satisfatória em um contexto semelhante ao dos estudos de caso.

O projeto desenvolvido possui um momento de experimentação prática, configurando um ensaio de viabilidade construtiva das técnicas empregada. Tal experimentação é feita no universo acadêmico como uma primeira experiência antes de uma aplicação no universo para o qual foi pensada. Assim, o projeto desenvolvido e executado dentro do espaço físico da Faculdade de Arquitetura e Urbanismo da Universidade de São Paulo atende às questões de outro contexto espacial, o do baixo Vale do Ribeira.

A metodologia utilizada para o desenvolvimento do projeto baseia-se em três fatores que desencadeiam inúmeros subfatores:

1. contexto específico: contexto social e técnico das comunidades caiçaras e ribeirinhas do Vale do Ribeira;

2. estudo de caso: os casos de projetos de habitação de interesse social estudados na presente pesquisa;

3. normas de construção: no caso, foram utilizadas as normas colombianas de construção em guadua (Figura 122). 


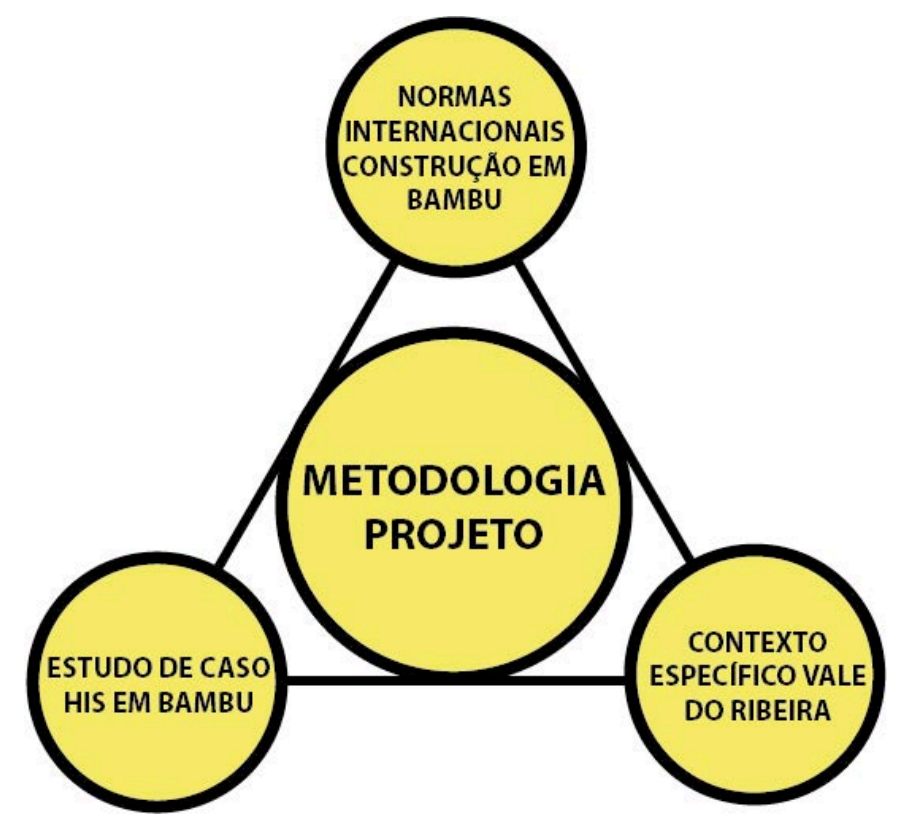

Figura 122 - Diagrama metodologia de projeto de sistema construtivo em bambu.

Fonte: acervo da autora.

\subsubsection{2 - Contexto específico}

Primeiramente, as premissas sociais foram o embasamento principal para que a proposta se adequasse ao contexto das comunidades caiçaras e ribeirinhas, visto que esta só se justificaria se levando em consideração as principais características socioculturais da população do Vale. Entre tais premissas sociais do contexto adotadas pelo partido do projeto foram:

- assimilação da arquitetura tradicional, valorizando o saber popular e seu espírito construtivo funcional;

- cultura construtiva intimamente ligada ao meio, utilizando-se parcimoniosamente as matérias-primas existentes e de fácil alcance;

- envolvimento do usuário/produtor com o processo construtivo, artífice do seu meio;

- processo produtivo que promova a articulação comunitária e o estreitamento de suas relações;

- processo produtivo que possibilite formação da mão-de-obra e consequentemente gere autonomia comunitária. 
Além das premissas sociais, o contexto também gerou as premissas técnicas relacionadas às culturas construtivas como:

- autonomia produtiva e autonomia na provisão de matérias-primas;

- tradição coletiva das organizações sociais: construção com ajuda-mútua/mutirão;

- habitações construídas em etapas, conforme demanda da família;

- familiaridade com técnicas construtivas em terra crua (pau-a-pique, terra batida, reboco de terra);

- familiaridade com técnicas construtivas em madeira e fibras naturais (vedação em madeira, bambu, estrutura pau-a-pique, coberturas em sapê e folhas de palmeiras)

- familiaridade com mescla de técnicas, assimilação de novas e antigas técnicas concomitantemente, sobreposição de técnicas.

Desta forma, conforme já citado anteriormente, as premissas do contexto específico justificam o emprego do material bambu por representar:

- uma cultura agrícola adaptada às condições locais, já produzida no Vale do Ribeira;

- um alívio à pressão para a exploração de madeiras em ecossistemas ameaçados;

- importante item na regeneração e proteção ambiental;

- grande rendimento anual por unidade de área;

- fácil domínio de todo o processo produtivo da matéria;

- importante meio de formação social, inserindo e qualificando tal população.

Dentro da definição do material, as espécies disponíveis em mais abundância no local foram aquelas utilizadas para a elaboração do projeto, sendo as espécies entouceirantes:

- Dendrocalamus giganteus;

- Bambusa tuldoides. 

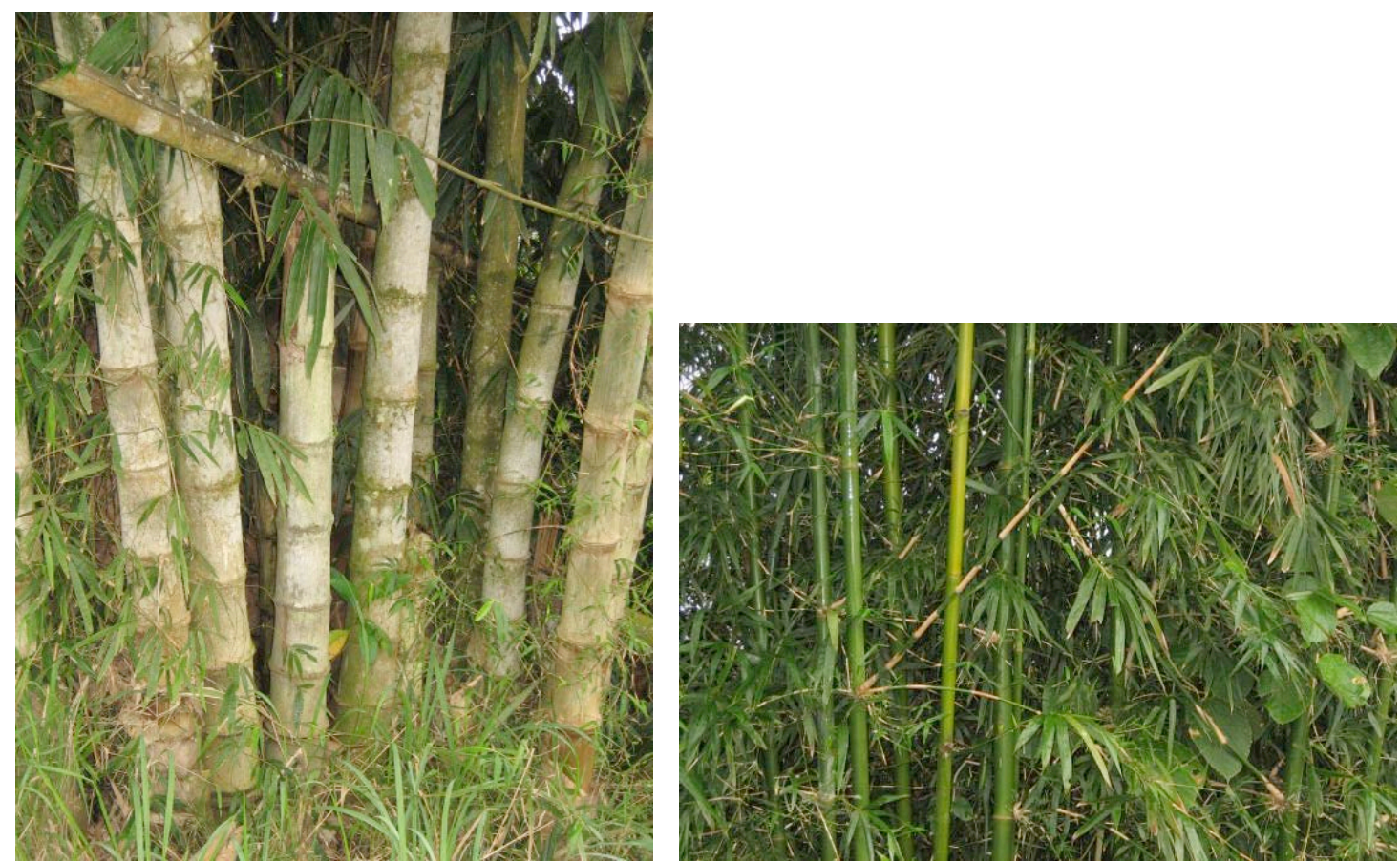

Figuras 123 e 124 - Bambus Dendrocalamus giganteus e Bambusa tuldoides no Vale do Ribeira.

Fonte: acervo da autora.

\subsubsection{3 - Estudo de caso}

Uma vez determinados os materiais empregados, o segundo fator determinante para a elaboração do projeto foi os casos de projetos de habitação de interesse social estudados na presente pesquisa. Tais exemplos, analisados sob aspectos produtivos, técnicos e sociais representam uma aproximação às questões contextuais da presente pesquisa.

Em cada um dos casos estudados, seus principais aspectos abordados podem ser rebatidos para o projeto da presente pesquisa, gerando algumas respostas específicas para o norteamento do projeto. Assim, dentre os quesitos avaliados, o presente projeto delimita:

- iniciativa: local, da associação de produtores rurais e artesãos do Vale do Ribeira, autoconstrução baseada em ajuda mútua, possibilidade de financiamento junto aos órgãos públicos;

- projeto arquitetônico: há uma primeira abordagem geral do projeto arquitetônico, mas este pode ser desenvolvido em conjunto conforme 
necessidades particulares de cada família, de acordo com alguns projetos estudados. Projeto modular adaptável quanto à espacialidade;

- inserção da comunidade: por meio de um projeto participativo, baseado nas técnicas pesquisadas, com sistemas abertos e em elaboração;

- produto: habitação unifamiliar térrea, de variadas tipologias e metragens, podendo gerar subprodutos de acordo com a incorporação da técnica;

- processo: apropriação de algumas técnicas pesquisadas, adaptação de outras. Criação de uma estrutura específica que ao consolidar-se configura um espaço de trabalho e produção;

- Mão-de-obra: local, com ênfase na formação e ajuda-mútua;

- Materiais: predominantemente de extração local (bambu, terra estabilizada) e poucos componentes de conexão;

- Resultados: consolidação de uma nova prática construtiva.

\subsubsection{4 - Normas de construção}

O último fator metodológico, foi o normativo, baseado nas normas colombianas para o processo de tratamento e construção com a guadua Guadua angustifolia Kunth.

- NTC 5300. "Cosecha y Poscosecha de los culmos de Guadua angustifolia Kunth".

- NTC 5301. "Preservación y secado del culmo de Guadua angustifolia Kunth".

- NTC 5407. "Uniones de estructuras con Guadua angustifolia Kunth".

Apesar da utilização do bambu Dendrocalamus giganteus como elemento estrutural, a norma baseada no bambu Guadua angustifolia Kunth foi utilizada como metodologia por ser, dentre as normas de construção existentes, aquela que mais se adequaria às características da espécie. Esse fator, de caráter técnico, balizou as decisões de projeto relacionadas às conexões, bem como definiu o processo de colheita e de tratamento do bambu utilizado. 


\subsection{2 - Projeto}

O partido principal do projeto é o da habitação modular por diversas justificativas. Primeiramente, tal condição possibilita diversas opções de arranjo espacial, configurando as mais variadas implantações. Em segundo lugar, a habitação composta por espaços modulares promove liberdade de definição do programa de necessidades do projeto pelo próprio usuário, possibilitando variados modelos de habitação com variadas metragens. Essa modulação possibilita que a construção seja feita em etapas interdependentes, de acordo com a necessidade de cada família, configurando importante premissa pesquisada nas práticas de autoconstrução do Vale. Além disso, a modulação do projeto contempla a necessidade de uma racionalização da subdivisão espacial do sistema estrutural, garantindo assim um sistema construtivo que distribui-se homogeneamente, como demandam os sistemas construtivos em bambu. Assim, representa um importante método de apropriação do usuário do projeto arquitetônico sem deixar de contemplar as demandas técnicoconstrutivas que garantem a qualidade e segurança da edificação, como tamanho dos vãos, aberturas mínimas para insolação e ventilação, dentre outros (Figura 125).
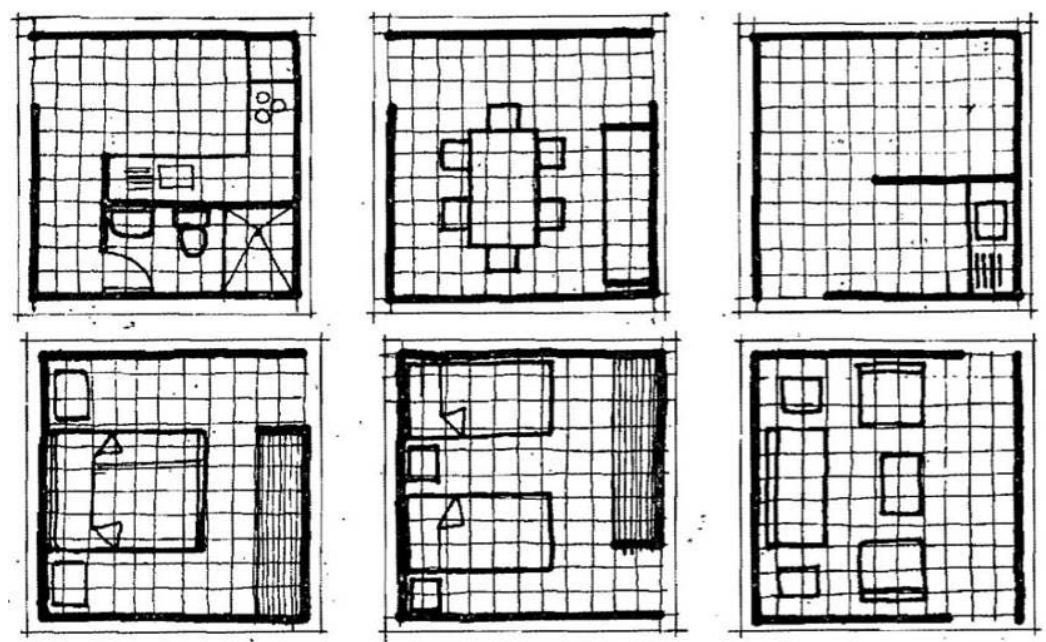

Figura 125 - Espaços modulares em sistema normatizado de madeira e guadua.

Fonte: SEBÁ 1986.

A modulação dos espaços é feita por meio da unidade de $3 \mathrm{~m} \times 3 \mathrm{~m}$, que configura o embrião desencadeador do desdobramento dos espaços, conforme a necessidade do projeto. A associação de mais de um módulo é feita pelo acréscimo de outro módulo sem sobreposição de componentes estruturais de cada um dos módulos, ou seja, dobramento de pilares e vigas. 

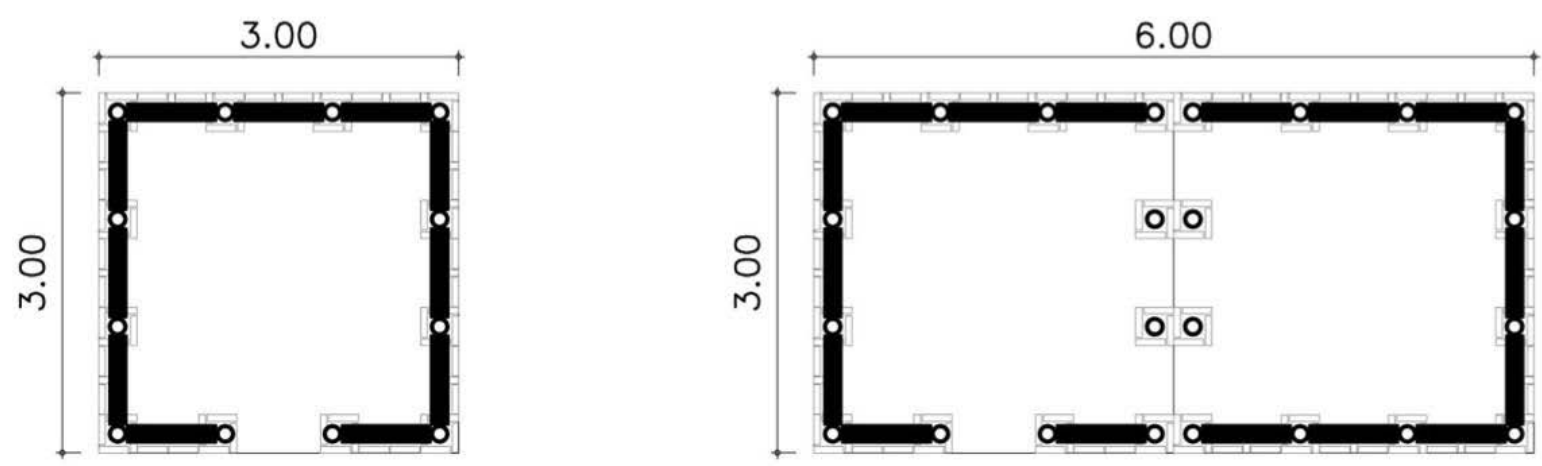

Figura 126 - Módulo simples (9 m2) e união entre módulos.

Fonte: Autoria própria.

O acréscimo de módulos pode ser feito na medida que a demanda familiar por novos espaços se amplie, sem necessidade de desocupação dos espaços já existentes. Cada módulo/unidade é estruturalmente autônomo, possuindo fundação e estrutura independente da vedação, podendo assim integrar suas faces.

O processo construtivo para a execução das habitações deve ser organizado em torno de uma linha de produção, organizada pelos habitantes locais. Com a montagem de uma pequena infraestrutura comunitária, os habitantes podem trabalhar o processo de produção do bambu a ser utilizado na construção, desde a colheita, tratamento, beneficiamento, pré-fabricação de peças, até a montagem. Essa estrutura de baixa tecnologia exige ferramentas predominantemente manuais, configurando assim um canteiro de construções de baixo investimento.

As fundações elaboradas podem ser do tipo fundações rasas como: sapatas corridas ou radiers, dependendo do tipo de solo. No projeto desenvolvido, a fundação escolhida foi a em radier, pela característica dos solos moles com baixa resistência. Na execução do radier já se concretam as esperas para os pilares da estrutura em bambu.

A estrutura, leve, é composta por peças de bambu da espécie D. giganteus de, aproximadamente, $15 \mathrm{~cm}$ de diâmetro. O sistema escolhido é o convencional viga-pilar, por ser um sistema análogo aos sistemas das tradicionais cabanas de madeira caiçara. Os encaixes são feitos em boca de pescado adaptado para corte reto, priorizando uma simples execução, e elementos de conexão de baixo custo como barras roscadas, parafusos e graute para estabilização das conexões, conforme a norma NTC 5407. 


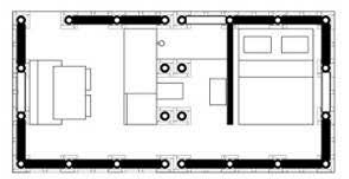

2 MÓdULOS (18 m2)

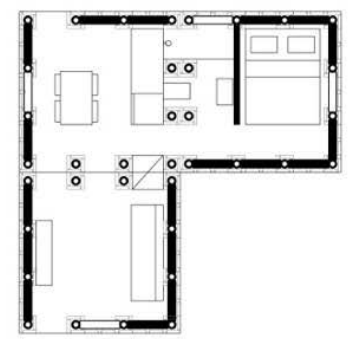

3 MODULOS (27 m2)

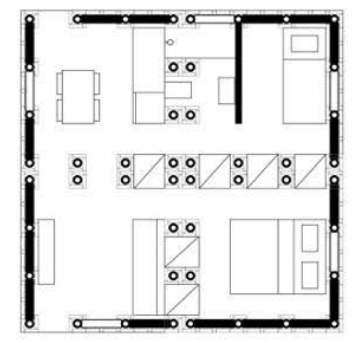

4 MóduLOS (36 m2)

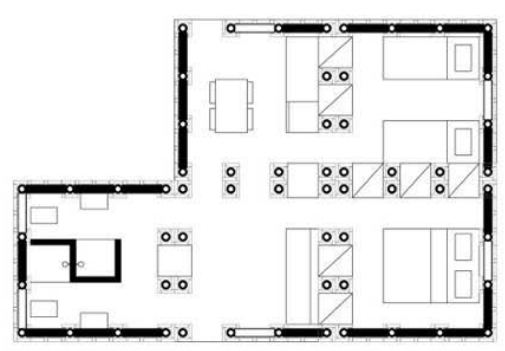

5 MÓdULOS (45 m2)

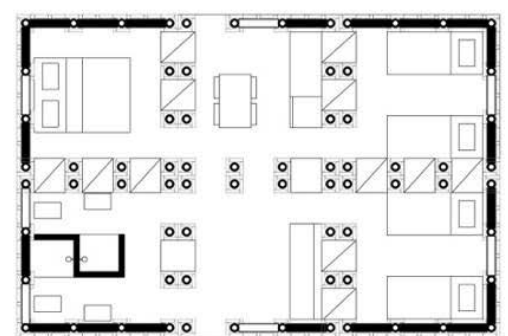

6 MODULOS (54 m2)

Figura 127 - Ampliação da habitação pela união de módulos.

Fonte: Autoria própria.

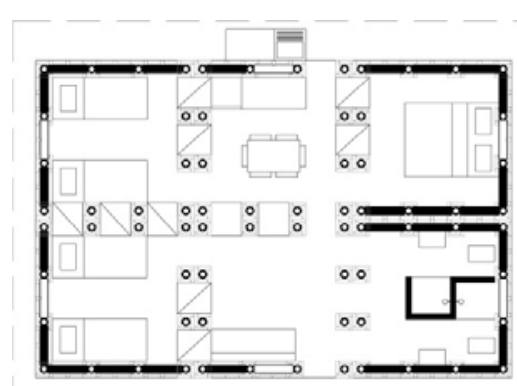

ARRANJO $1(54 \mathrm{~m} 2)$

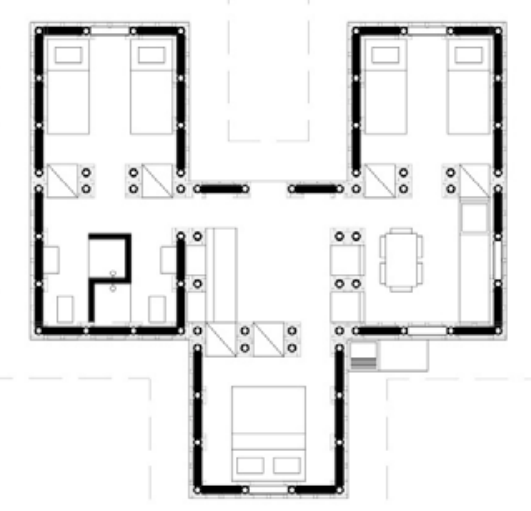

ARRANJO $3(54 \mathrm{~m} 2)$

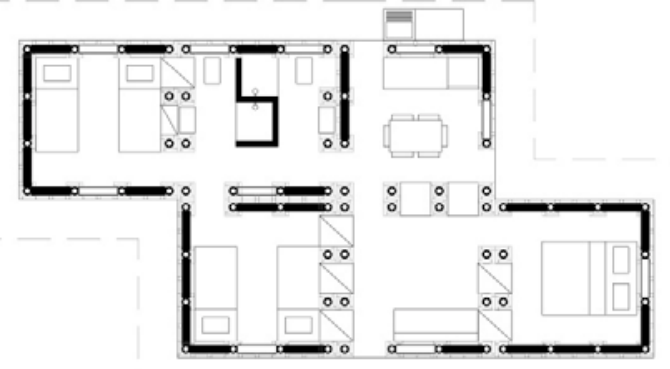

ARRANJO $2(54 \mathrm{~m} 2)$

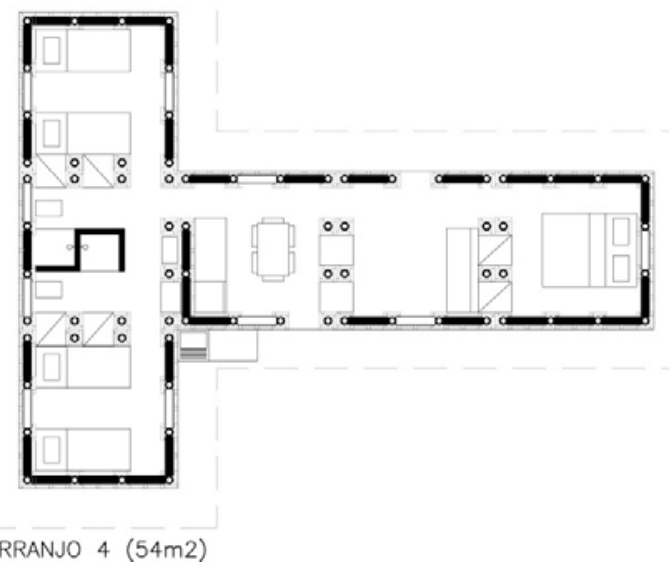

Figura 128 - Possibilidades de arranjo de habitação 54 m2.

Fonte: Autoria própria. 


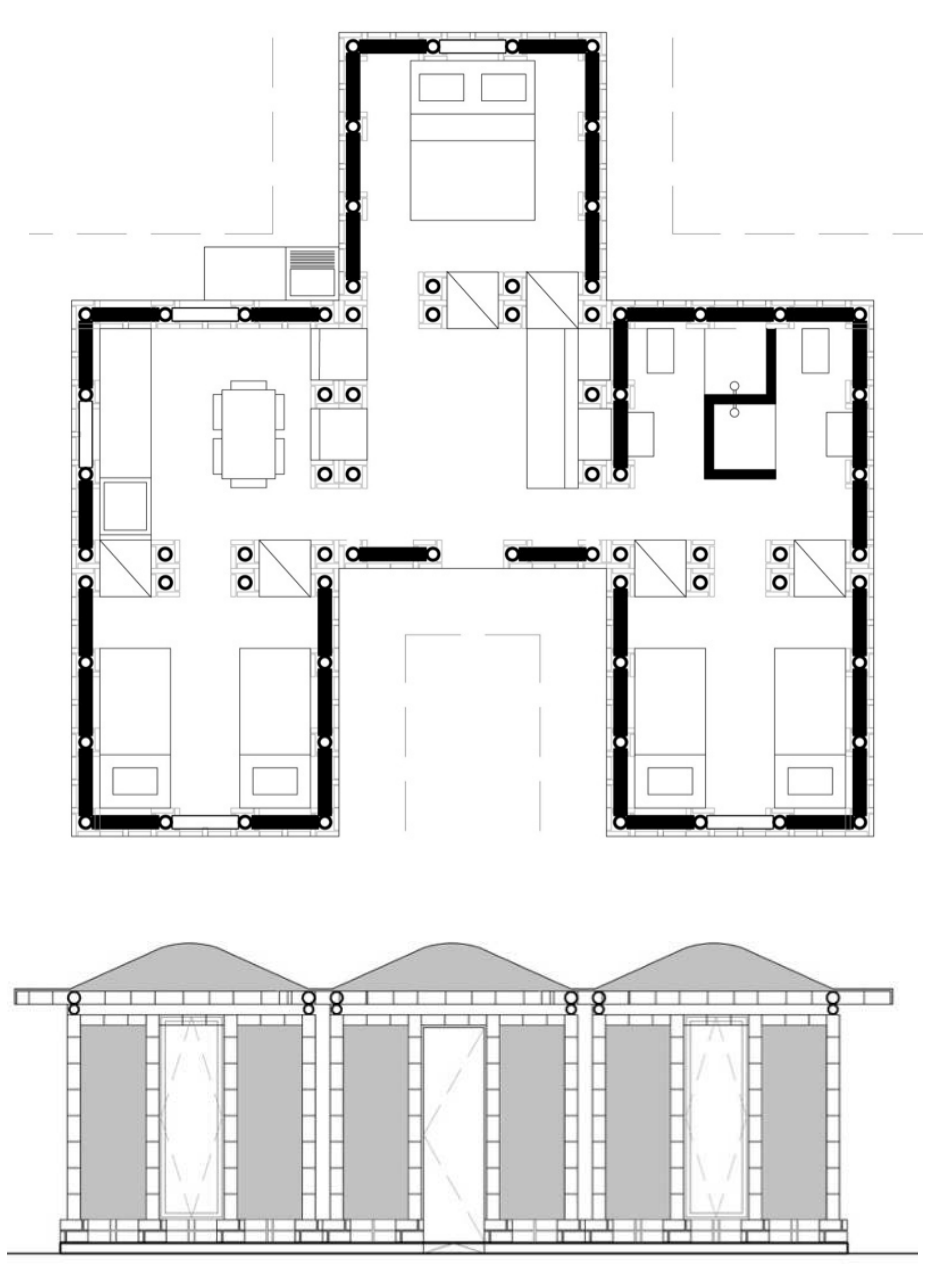

Figura 129 - Tipologia de habitação de 54 m2.

Fonte: Autoria própria.

A vedação é composta por painéis tramados de bambu da espécie B. tuldoides, compondo painéis diafragma que contraventam a estrutura de bambu gigante. Os painéis são estruturados por ripas de madeira de $5 \mathrm{~cm} \times 2 \mathrm{~cm}$ e tramados com taliscas extraídas do B. tuldoides. Após tramados, é fixada sobre os painéis uma malha de tela de viveiro, para melhor adesão do reboco. Os painéis são barreados com solo-cimento, fazendo alusão à técnica de pau-a-pique comumente empregada nas comunidades ribeirinhas do Vale. Após o barreado, o painel é rebocado e acabado. $\mathrm{O}$ acabamento serve como proteção do bambu de vedação às intempéries, uma vez que o ambiente litorâneo é agressivo.

Tal técnica utilizada assemelha-se à tradicional técnica construtiva peruana em terra crua chamada quincha. Também há no tramado dos painéis a referência ao trabalho sobre painéis em trama de bambu para vedação de moradias realizado por Pereira et al. (2011). 
Além disso, há a alusão também à técnica da confecção de cestarias, amplamente praticada entre os artesãos locais.

A cobertura dos módulos é projetada com sua estrutura em bambu $D$. giganteus e meias-canas de $B$. tuldoides, que forma uma fôrma perdida de bambu a ser preenchida com argamassa. Assim, cada módulo é coberto por sua cúpula-triangular de argamassa.

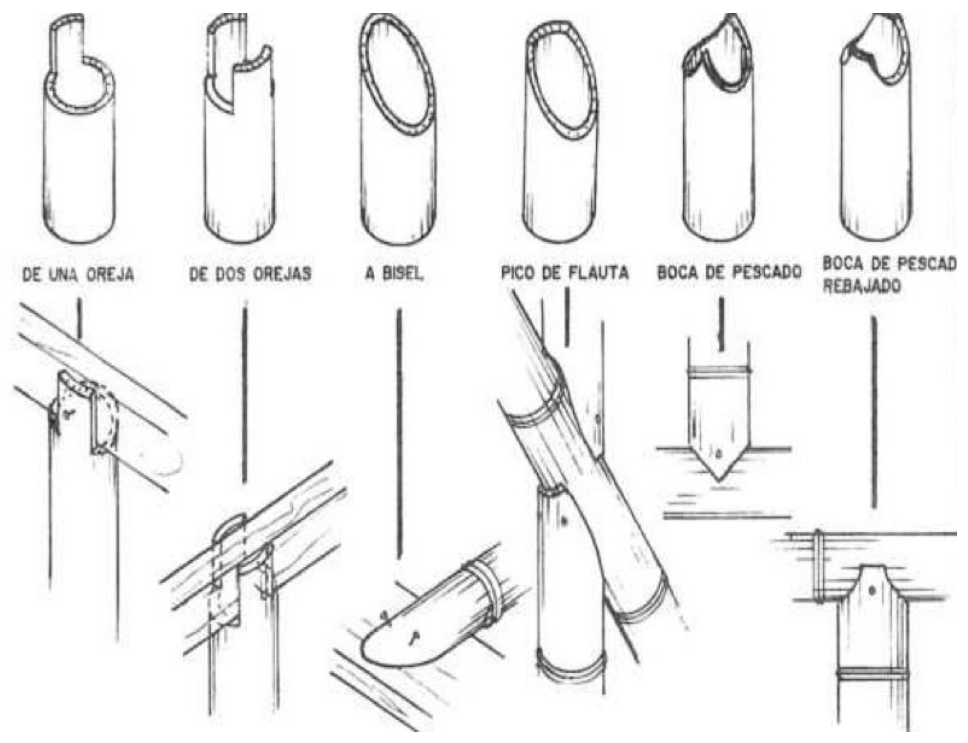

Figura 130 - Possibilidades de boca de pescado. Aplicada a "de dos orejas". Fonte: http://www.buenastareas.com/

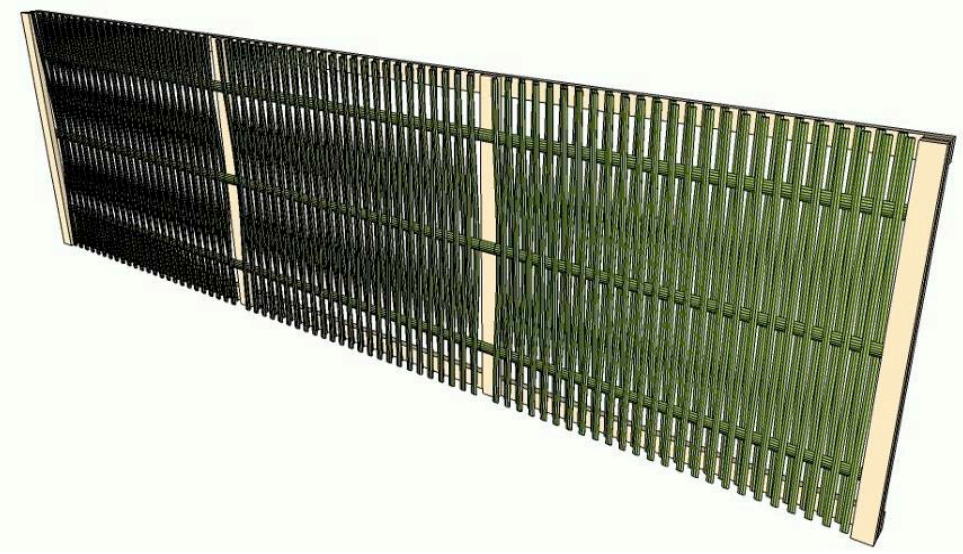

Figura 131 - Painel de vedação simples tramado em B. tuldoides.

Fonte: Autoria própria. 


\section{2 - Ensaios de Viabilidade de Execução}

\subsection{1 - Procedimentos de elaboração do protótipo.}

\subsubsection{1 - Introdução}

Além da avaliação de viabilidade construtiva do protótipo no momento de pósconstrução, o próprio processo produtivo desempenha importante papel na avaliação da empregabilidade desses procedimentos no contexto da pesquisa. Assim, tanto as conclusões determinadas pelo resultado obtido pelo protótipo quanto o processo de produção do mesmo são objeto de avaliação pautada nos elementos balizadores e restritivos do universo existente das comunidades caiçaras e ribeirinhas do Vale do Ribeira.

No caso do protótipo de viabilidade construtiva foi construído no Canteiro Experimental da FAU USP, utilizando o espaço físico e a infraestrutura ali existente. Também foi utilizada a estrutura do LAME (Laboratório de Modelos e Ensaios) bem como o auxílio técnico de funcionários do LAME, principalmente do técnico do Canteiro Experimental da FAU USP Romerito Fonseca Ferraz.

A locação do protótipo no espaço livre do Canteiro Experimental foi estabelecida em conversa com os professores responsáveis pela coordenação do espaço, Profa. Dra. Erica Yoshioka e Prof. Dr. Reginaldo Ronconi, de acordo com o estudo de implantação para as atividades de ensino e pesquisa do local, e para um possível uso do espaço em atividades futuras (Figura 132).

O escopo do protótipo é avaliar, em seu processo de construção, o desempenho e a viabilidade construtiva das técnicas propostas em um ambiente de trabalho com estrutura e mão-de-obra similar. No caso, o projeto do protótipo contempla a estrutura de um módulo da unidade habitacional $(3 \mathrm{~m} \times 3 \mathrm{~m}$ ), suas respectivas conexões e o teste de painéis de vedação na técnica anteriormente descrita. O projeto completo do protótipo encontra-se nos apêndices (Figura 133). 


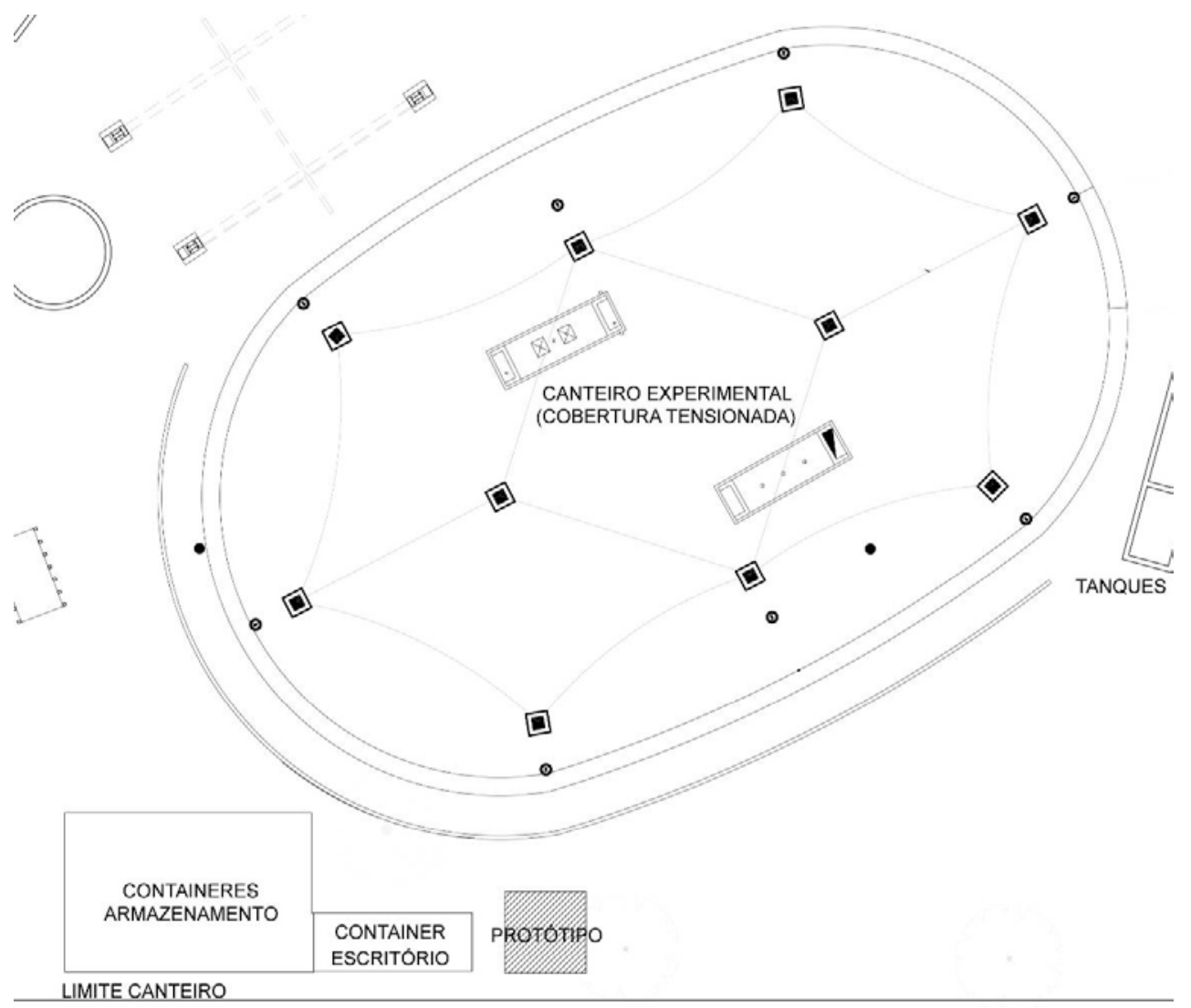

Figura 132 - Implantação do protótipo no canteiro experimental.

Fonte: Adaptado de LCC - FAU USP.
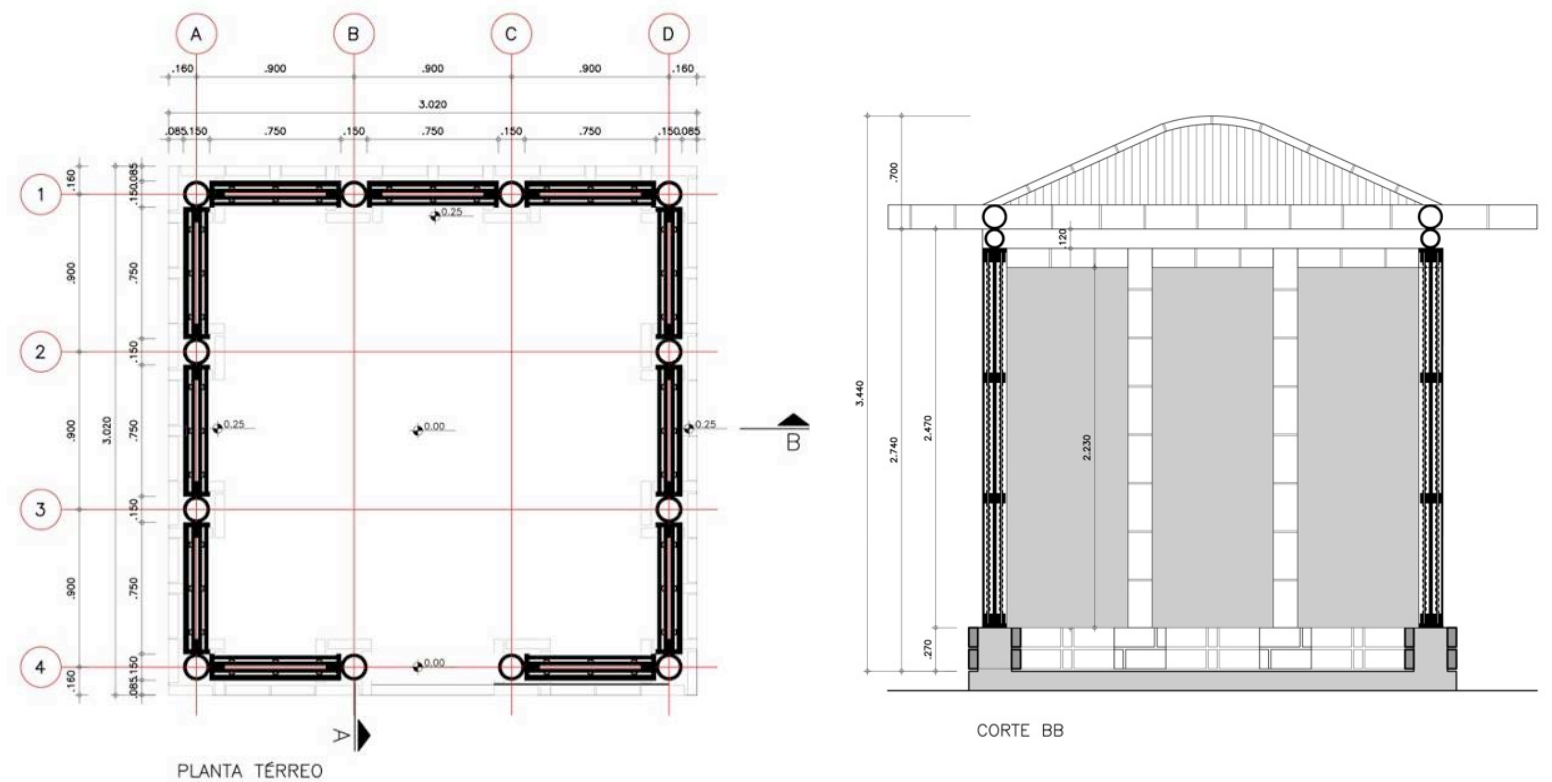

Figura 133 - Projeto do módulo (9 m2) da unidade habitacional. 
Fonte: Autoria própria.

\subsubsection{2 - Materiais e estrutura}

O intuito da realização do protótipo de ensaio de viabilidade de execução é a experimentação dos materiais e processos pesquisados e sugeridos na presente pesquisa. Tal avaliação de experimentação será feita em relação ao processo, materiais e métodos desenvolvidos, justificando ou não a viabilidade de sua realização em um contexto similar para o qual este foi pensado.

Conforme já mencionado, a linha de produção pode ser organizada de maneira comunitária, contemplando as etapas de colheita, tratamento, beneficiamento, préfabricação de peças até a montagem. Tais materiais, por serem predominantemente manuais, necessitam baixo investimento. Na Tabela 7, relacionam-se os principais materiais necessários para uma infraestrutura inicial.

\subsubsection{3 - Escolha das espécies e local de extração}

Conforme citado anteriormente, foram escolhidos para o projeto em questão os colmos das espécies entouceirantes $D$. giganteus e $B$. tuldoides por serem registradas como espécies já presentes em abundância na Região do baixo Vale do Ribeira. A D. giganteus exerce no sistema proposto a característica de estrutura principal, por apresentar grande espessura de parede do colmo. Foram escolhidos exemplares de diâmetro de $16 \mathrm{~cm}$ que estimou-se que com idade estimada de 3 anos ou mais de idade e que apresentassem um aspecto mais retilíneo e uniforme em sua extensão útil. Também foram extraídos colmos das espécies $B$. tuldoides para a elaboração de estrutura secundária/vedação dos painéis devido à sua menor espessura de parede e maior flexibilidade.

O local escolhido para a extração das espécies foi o Viveiro de Plantas da Universidade de São Paulo, pertencente à área de Gestão Ambiental do Campus da Capital e responsável pela manutenção de jardins e canteiros, e serviços de plantio, produção de mudas e produção de compostos orgânicos para adubação. A escolha deste fornecedor dos colmos para a elaboração do protótipo deu-se pela existência de convênio entre o Viveiro de Mudas da USP e a Faculdade de Arquitetura e Urbanismo, pela existência das mesmas espécies presentes no Vale do Ribeira e pela viabilidade do transporte do material. 
Tabela 7 - Instrumentos para implantação de linha de produção em bambu.

Fonte: Autoria própria, pesquisas de preço feitas em Julho de 2012.

\begin{tabular}{|c|c|c|c|c|}
\hline \multicolumn{5}{|c|}{ LINHA DE PRODUÇÃO HABITAÇÃO EM BAMBU - INVESTIMENTO INICIAL } \\
\hline EQUIPAMENTOS & MODELO & QUANTIDADE & VALOR UNITÁRIO (R\$) & VALOR TOTAL (R\$) \\
\hline \multicolumn{5}{|c|}{ 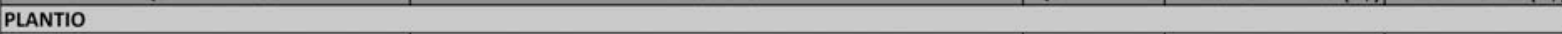 } \\
\hline ADUBO & NPK 20-05-20 & 20 & 3.00 & 60.00 \\
\hline ENXADA & Enxada com Cabo Madeira de $150 \mathrm{~cm}$ & 2 & 16.06 & 32.12 \\
\hline PICARETA & Picareta Chibanca com Cabo de Madeira de $90 \mathrm{~cm}$ & 2 & 27.33 & 54.66 \\
\hline ENXADÃO & Enxadão Largo e Leve com Cabo de Madeira de $150 \mathrm{~cm}$ & 2 & 16.43 & 32.86 \\
\hline PÁ DE BICO & Pá de Bico com Cabo de Madeira $120 \mathrm{~cm}$ & 2 & 19.49 & 38.98 \\
\hline \multicolumn{5}{|l|}{ COLHEITA } \\
\hline SERROTE & 24" - 8 DPP & 2 & 34.42 & 68.84 \\
\hline SERROTE & $12^{\prime \prime}-$ de Costa & 2 & 25.15 & 50.30 \\
\hline SERROTE PARA PODA & Podador Curvo - 1135-380 & 2 & 80.00 & 160.00 \\
\hline LIMA & Lima para serrote de poda & 1 & 32.90 & 32.90 \\
\hline LIMA & Lima grossa $10^{\prime \prime}$ & 1 & 35.81 & 35.81 \\
\hline MACHADO & Machado 334-2 & 1 & 89.50 & 89.50 \\
\hline MACHADO & Machado $334-3,5$ & 1 & 115.00 & 115.00 \\
\hline FACÃO & Facão com Cabo de Madeira 16" & 3 & 13.71 & 41.13 \\
\hline MOTO-SERRA & A gasolina, 235 E-SERIES, 1,7CV@13.000RPM & 1 & 605.30 & 605.30 \\
\hline \multicolumn{5}{|c|}{ TRATAMENTO E ARMAZENAMENTO } \\
\hline TANQUE PARA IMERSÃO & A ser executado em alvenaria com travas metálicas & 1 & 5000.00 & 5000.00 \\
\hline ESTANTES & A ser executada em bambu e ferragens metálicas & 2 & 3000.00 & 6000.00 \\
\hline \multicolumn{5}{|l|}{ BENEFICIAMENTO } \\
\hline SERRA CIRCULAR & 1800W 5007N com Guia de Corte e Lâmina de Serra & 1 & 789.00 & 789.00 \\
\hline SERRA DE FITA & Serra de Fita Profissional SF-9 - $1 / 2$ CV - Bivolt & 1 & 999.00 & 999.00 \\
\hline SERRA RADIAL & A ser executada sob encomenda & 1 & 1500.00 & 1500.00 \\
\hline SERRA TICO-TICO & $450 \mathrm{~W} 4327$ & 2 & 349.00 & 698.00 \\
\hline LIXADEIRA & Lixadeira / Politriz Angular 7 Eletrônica 1600 Watts $220 \mathrm{~V}$ & 2 & 500.75 & 1001.50 \\
\hline FURADEIRA & Furadeira de Impacto com Encaixe 1/2pol. 680W 110V & 2 & 207.95 & 415.90 \\
\hline PARAFUSADEIRA & Parafusadeira 570 watts $220 \mathrm{~V}$ & 2 & 477.76 & 955.52 \\
\hline PLAINA & Plaina Elétrica $82 \mathrm{~mm} 3-1 / 4 \mathrm{pol} .620 \mathrm{~W}$ & 2 & 392.53 & 785.06 \\
\hline TRENA ELETRÔNICA À LASER & Trena Eletrônica Digital Portátil com Mira Laser TR-180 & 2 & 113.90 & 227.80 \\
\hline TRENA & Trena Emborrachada $3 \mathrm{~m} \times 16 \mathrm{~mm}$ com Imã na Ponta & 4 & 7.90 & 31.60 \\
\hline ESQUADRO PROFISSIONAL & Esquadro de Alumínio Profissional Black Jack $40 \mathrm{~cm}$ & 4 & 24.90 & 99.60 \\
\hline JOGO DE FORMŌES & Kit Formão 3 Peças & 2 & 117.60 & 235.20 \\
\hline JOGO DE FORMŌES & Kit Formão Com Cabo Emborrachado 6 Peças Cromo Vanádium & 1 & 69.90 & 69.90 \\
\hline GRAMPO SARGENTO & Grampo Tipo 'C' 4" Sargento Ferro Nodular C120 & 4 & 14.90 & 59.60 \\
\hline GRAMPO SARGENTO & Grampo Tipo 'C' 8" Sargento Ferro Nodular C120 & 4 & 25.90 & 103.60 \\
\hline SARGENTO BARRA & Sargento Barra T 1,00 m & 2 & 135.73 & 271.46 \\
\hline NÍVEL DE ALUMÍNIO & Nivel de Alumínio Graduado 400mm com Base Magnética D185 & 4 & 24.90 & 99.60 \\
\hline NÍVEL À LASER & Nivel Laser de Marcacao com Maleta e Tripé & 1 & 239.00 & 239.00 \\
\hline ESTILETE & Estilete Profissional Tramontina 6" - Amarelo & 6 & 9.90 & 59.40 \\
\hline FACA RADIAL & A ser executada sob encomenda & 3 & 250.00 & 750.00 \\
\hline \multicolumn{5}{|l|}{ MONTAGEM } \\
\hline BARRA ROSCADA & Barra roscada de $1 \mathrm{~m}$ e $3 / 8^{\prime \prime}$ & 50 & 11.00 & 550.00 \\
\hline PORCA & Porca $3 / 8^{\prime \prime}$ & 160 & 0.54 & 86.40 \\
\hline ARRUELA & & 160 & 0.46 & 73.60 \\
\hline & & TOTAL RS & 22518.14 \\
\hline
\end{tabular}

\subsubsection{4 - Escolha dos colmos - seleção e marcação}

Usando como referência metodológica a Norma técnica colombiana NTC 5300 sobre colheita e pós colheita do colmo de Guadua angustifolia Kunth, iniciou-se o processo de seleção e marcação dos colmos a serem retirados. Estes deveriam cumprir aos seguintes requisitos:

- estado de maturidade: a ser reconhecido por sua forma visual, conforme se descreve posteriormente; 
- estado fitossanitário: estado são, sem apresentar danos causados por fungos e /ou insetos, como perfurações e outros;

- estado físico: não apresentar defeitos como rachaduras, perfurações e outros danos físico-mecânicos.

Os colmos destinados à usos estruturais devem ser colmos maduros, com idade mínima de 3 anos (HIDALGO-LOPEZ, 2003).

$\mathrm{O}$ amadurecimento dos tecidos constituintes do bambu entre o terceiro e sétimo ano garante ao material maior resistência mecânica. A avaliação dos colmos que cumprem tais requisitos é muito complexa sendo que o método prático estabelecido comumente é a observação de algumas características físicas nos colmos existentes na touceira.

O colmo mais jovem apresenta uma coloração mais verde, e possui em seus nós mais inferiores as folhas caulinares e, em geral, se localizam na parte externa da touceira, no caso dos bambus entouceirantes. Já o colmo que possui mais de três anos possui uma coloração mais amarelada, não possuem mais as folhas caulinares, localizam-se mais ao interior da touceira e apresentam em sua parede externa manchas causadas por líquens (PEREIRA; BERALDO 2008).

Assim, baseado em projeto específico, foram escolhidos 12 colmos da espécie $D$. giganteus com aparência madura, de mais de três anos e 20 colmos da espécie $B$. tuldoides com aparência mais jovem, para garantir a flexibilidade. Ao final do processo todos os bambus escolhidos foram marcados para ser retirados das respectivas touceiras. 

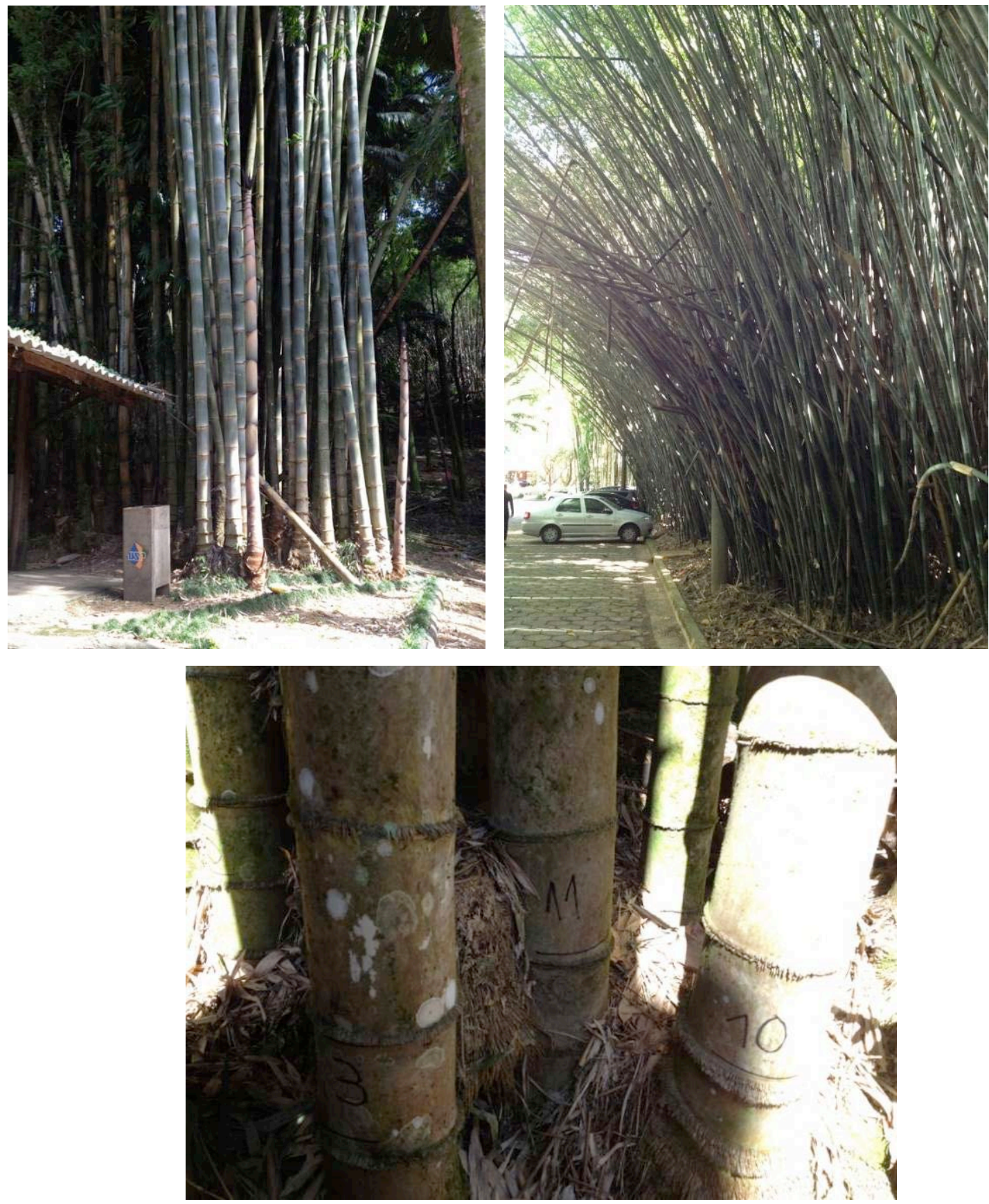

Figuras 134, 135 e 136 - Touceira de D. giganteus, touceira de B. tuldoides e marcação dos colmos de D. giganteus maduros.

Fonte: Autoria própria. 


\subsubsection{5 - Corte}

A colheita periódica de colmos maduros das touceiras configura um bom procedimento de manejo uma vez que possibilita espaço para o crescimento de novos colmos. O momento ideal para corte de colmos dos bambus entouceirantes deve ser a estação de seca, na qual a umidade encontrada é mais baixa, e consequentemente a quantidade de seiva é menor, garantindo um menor risco de ocorrência de ataque de insetos xilófagos.

As mais diversas referências bibliográficas afirmam que o período de melhor momento para a colheita dos bambus é o inverno, momento no qual os bambus estão com a maior quantidade de amido em seus rizomas, armazenando reservas para o período de surgimento de novos brotos. No hemisfério sul, esta fase se dá entre Maio e Agosto no caso de bambus entouceirantes. No caso da elaboração do protótipo em questão, por uma questão de cronograma, a colheita foi feita o quanto antes, no mês de Maio.

Há em grande parte da literatura a recomendação de que os cortes sejam realizados na fase lunar minguante. Janssen (1995) conclui que não há relação entre o corte baseado no calendário lunar e o ataque de insetos xilófagos, no entanto, afirma que não há nenhum impedimento técnico para a prática de tal crença local, quando for o caso.

Outra recomendação é a de que o corte seja realizado durante a madrugada ou cedo pela manhã, quando as atividades de fotossíntese ainda não se iniciaram e portanto há uma menor quantidade de líquido no interior do colmo (SANCHEZ; TOLE 2008). No caso, por ser uma atividade a ser realizada em um ambiente institucional mediante aos horários de funcionamento dos estabelecimentos e da jornada de trabalho dos técnicos auxiliares, o procedimento foi realizado o mais cedo possível, às sete horas da manhã.

O corte de colmos para a construção deve ser sempre realizado a uma altura de aproximadamente $30 \mathrm{~cm}$ acima do solo para espécies entouceirantes, na parte superior do primeiro ou segundo nó, e logo rente ao mesmo, para evitar o acúmulo de água na região e o possível apodrecimento do colmo restante e consequentemente do rizoma. Este procedimento pode ser feito utilizando um machado, facão ou motosserra, dependendo da espécie escolhida. No caso do bambu $D$. giganteus foi utilizada a motosserra e no caso do bambu espécie $B$. tuldoides, o facão foi o instrumento adequado. É necessário ressaltar a importância de tal procedimento ser feito por um operador capacitado e usando os adequados equipamentos de proteção. 


\subsubsection{6- Cura}

Imediatamente após o corte dos colmos de bambu é necessária a preparação desse material para o tratamento preservativo. Uma maneira de fazê-lo é iniciar o processo de cura/maturação na mata, considerado um tratamento tradicional que busca conservar as características e propriedades naturais do bambu, evitando a deterioração prematura do material.

O processo consiste na colocação, logo após o corte, dos bambus em posição vertical, sobre uma pedra ou superfície impermeável para que o processamento da seiva que ainda existe em seu interior elimine ao máximo a quantidade de amido e que esse processo de fermentação evite o ataque de insetos. Tal procedimento teve a duração de três semanas devido à dificuldade de retirada do material das touceiras em decorrência de um extenso período de chuvas que acometeu São Paulo no momento da realização do protótipo.
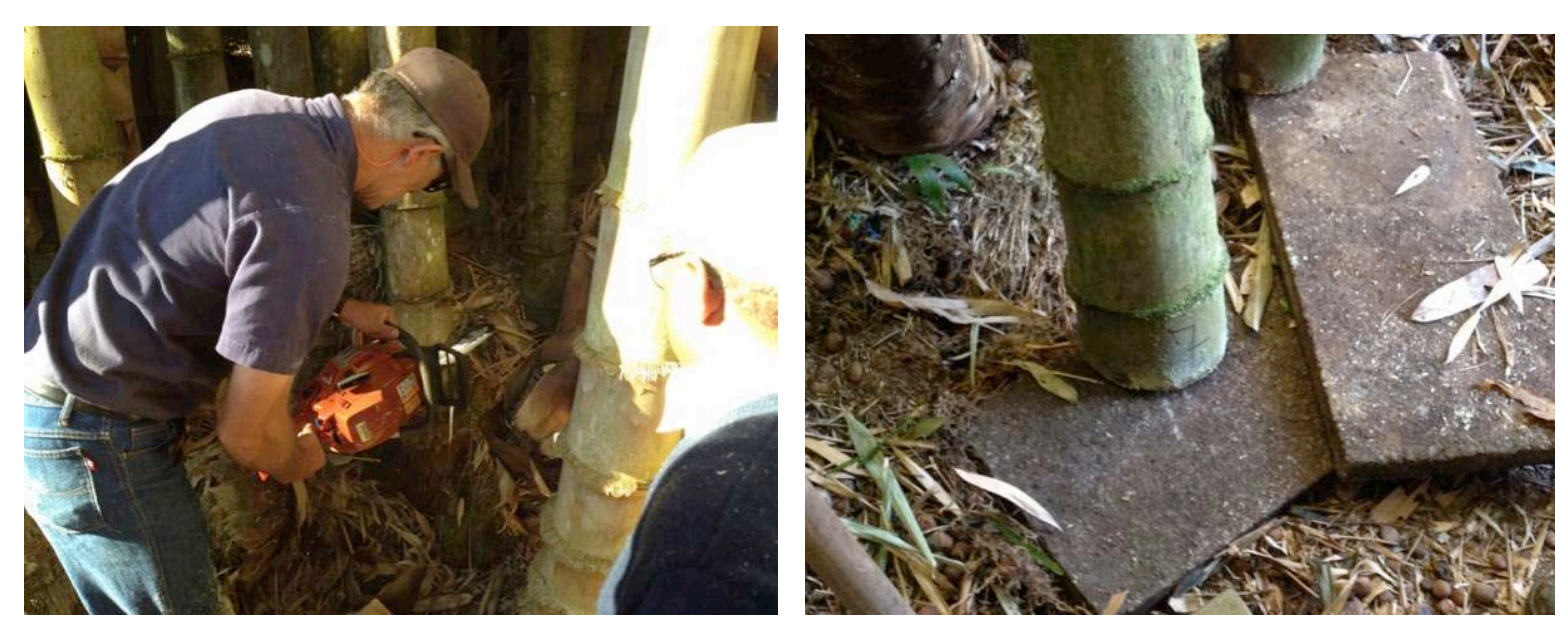

Figuras 137 e 138 - Corte do bambu D. giganteus e Processo de cura sobre placa de concreto.

Fonte: Autoria própria.

\subsubsection{7 - Subdivisão dos colmos}

Após a cura do colmo de bambu como um todo fez-se necessário a divisão deste em partes menores para a facilitação do transporte do material até o local de tratamento, o Canteiro Experimental da FAU USP. A escolha dos tamanhos de corte dos colmos foi feita em função das especificações de projeto e também em função das propriedades mecânicas variáveis de cada parte da extensão do colmo. 
Em linhas gerais, o bambu quando jovem devido à baixa dureza do colmo tem seu uso restrito à fabricação de cestarias, painéis e esterillas. Já o bambu maduro pode ter seu uso estrutural na construção e na fabricação de taliscas para pisos laminados.

Já quanto ao uso ao longo de sua extensão, este pode ser dividido em três partes:

- inferior: os primeiros $4 \mathrm{~m}$ inferiores do colmo. Sua menor distância entre os nós aumenta a resistência à flexão;

- médio: de 4 a $8 \mathrm{~m}$ de altura do colmo. Uso frequente para fabricação de esterillas que podem ser usadas para paredes e fôrmas. Também muito utilizado para a elaboração de colunas, sendo assim a parte mais comercializável do bambu estrutural;

- superior: de 8 a 12 m. Muito utilizado na confecção de escoras e pontaletes;

- copa: acima de $12 \mathrm{~m}$. Em geral deixado como matéria orgânica para proteção do solo (CAMACHO REYES; PAEZ RAMOS 2002).

Após o período de cura e considerados os usos atribuídos a estes bambus e à capacidade dos tanques destinados ao tratamento ${ }^{27}$, os colmos foram subdivididos em partes de 3 e $4 \mathrm{~m}$ de extensão, facilitando assim o transporte e manejo. As partes inferiores de cada colmo foram cortadas em peças de $4 \mathrm{~m}$ e as médias e superiores em peças de $3 \mathrm{~m}$.

\subsubsection{8 - Transporte}

Desde o momento após o corte, os colmos e as peças cortadas a partir do colmo devem ser manipulados com cuidado para evitar a deterioração do material por choques ou maus procedimentos. Tais medidas também devem ser aplicadas no momento do transporte do material (Figuras 139 e 140).

\footnotetext{
${ }^{27}$ Os tanques de tratamento utilizados no processo são os existentes no Canteiro Experimental para cura de peças de argamassa. Suas medidas são 1,65 $m \times 3,00 m \times 0,70 m$ e 1,65 $m \times 4,00 m \times 0,95 m$ (LXAXP).
} 

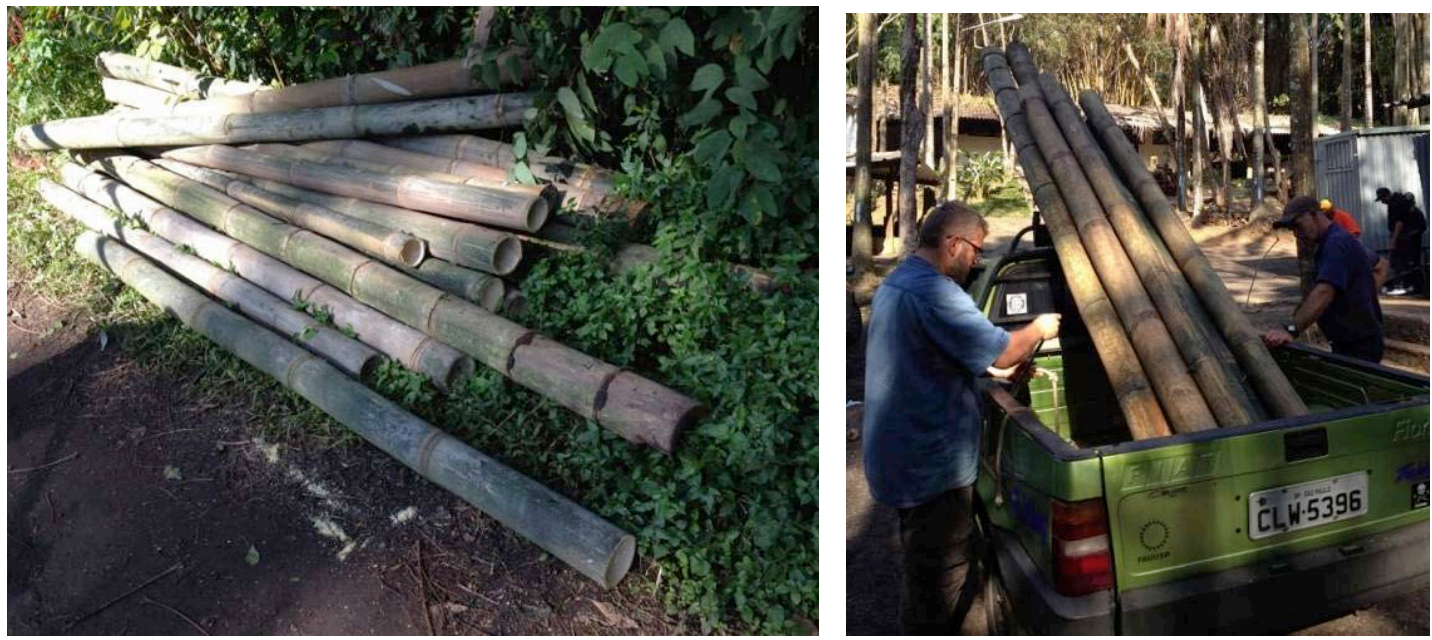

Figuras 139 e 140 - Colmos de bambu subdivididos e transporte das peças.

Fonte: Autoria própria.

Ainda, segundo a Norma técnica colombiana NTC 5300, durante o transporte devese:

- evitar qualquer tipo de impacto sobre o material;

- evitar acumulações horizontais superiores a 2,40 m para impedir esmagamentos.

\subsubsection{9 - Tratamento de imunização}

Após a limpeza dos colmos curados, iniciou-se o processo conhecido como imunização ou tratamento preservativo. Para a seleção do produto químico preservativo a ser escolhido deve-se ter em conta o uso final do produto, sua localização (interior/exterior) e as características ambientais do local ao qual se destina. $O$ local de trabalho também deve atender os requisitos de segurança de acordo com o preservativo escolhido. É importante atentar para a responsabilidade da escolha de tal produto preservativo para que seu processo não represente uma ameaça ao meio ambiente nem aos seres vivos.

Dentre os mais diversos procedimentos de tratamentos preservativos o tratamento escolhido foi o de imersão em solução de componentes químicos hidrossolúveis, no caso, o octoborato de sódio (ácido bórico e bórax) ${ }^{28}$. Tal componente possui uma boa eficácia e não representa uma tratamento químico tão agressivo quanto outros compostos hidrossolúveis

\footnotetext{
${ }^{28}$ Foi utilizado o produto Aquabor ${ }^{\circledR}$, octoborato dissódico tetrahidratado, da empresa Boro do Sul.
} 
como o CCA, além de ser um tratamento de execução compatível com a estrutura atual local.

O boro é um dos sete micronutrientes essenciais para o crescimento das plantas. 0 produto utilizado é um sal alcalino suave que consiste em um pó branco fino solúvel em água de inúmeros usos em mercados agroindustriais. Na madeira e no bambu, ele age como retardador de chama, além de impedir a deterioração da madeira por ataque microbial e de insetos xilófagos. Segundo Montoya (2002), uma solução de octoborato de sódio a 5\% seria eficiente para o devido tratamento de imunização do bambu.

É necessário atentar para as condições de limpeza e de decomposição da solução afim de garantir a efetividade do tratamento preservativo. As peças estruturais de bambu $D$. giganteus foram colocadas inteiras em um tanque de cura existente no canteiro experimental da FAU USP de dimensões de 4,00 m X 1,65 m (e 0,95 m de profundidade), contendo tal solução. As mesmas foram travadas transversalmente com tábuas e pesos para que não flutuassem e permanecessem totalmente imersas. Já as peças de $B$. tuldoides foram colocadas em um tanque de dimensões de 3,00 m X 1,65 m (e 0,70 m de profundidade). Para melhor ação da solução, a Norma técnica NTC 5301 sobre preservação e secagem do colmo de Guadua angustifolia Kunth sugere ou a perfuração interna dos diafragmas (nós) com um vergalhão de $1 / 2$ a 5/8 de polegada de diâmetro ou a perfuração transversal com o auxílio de brocas de $1 / 4$ de polegada. No caso a primeira opção foi escolhida, apesar de reduzir a capacidade estrutural do colmo, esta provoca menos rachaduras.

O tanque foi coberto com lona para que a solução utilizada não evaporasse e não se diluísse com a água da chuva. A duração do tratamento em geral é de uma a quatro semanas, e no presente caso, os bambus ficaram imersos por duas semanas na solução.

Foram utilizados os seguintes equipamentos e procedimentos de segurança:

- luvas, botas de borracha e aventais impermeáveis;

- não fumar nem ingerir alimentos durante o trabalho;

- manter a solução e o bambu recém tratado fora do alcance de crianças e animais (Figuras 141, 142, 143 e 144). 

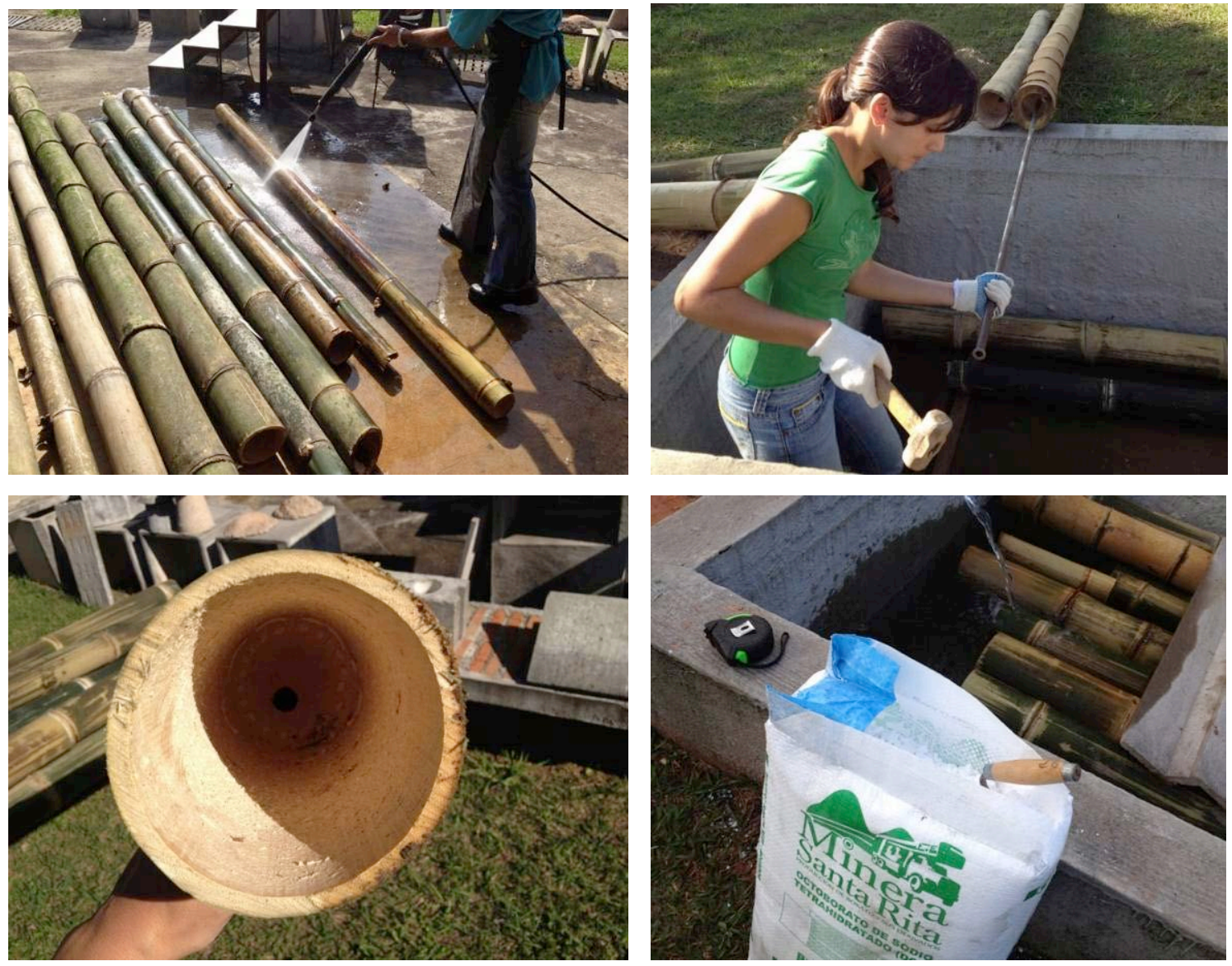

Figura 141, 142, 143 e 144 - Lavagem das peças, perfuração dos entrenós,

furo do entrenó e octoborato aplicado no tratamento.

Fonte: Autoria própria.

\subsubsection{0 - Secagem}

Logo após o término do tratamento, os colmos foram retirados do tanque e foram deixados para escorrer durante meio dia, para iniciar o processo de secagem. Tal processo, quando feito naturalmente realiza-se condicionado às variantes das condições ambientais locais. A NTC $5301^{29}$ aconselha que essa secagem seja feita sob coberta inicialmente, com os colmos separados entre si, para alcançar gradativamente o conteúdo de umidade de equilíbrio com a difusão radial, e assim foi feito. Após aproximadamente dois dias cobertos por lona, os bambus foram descobertos, e passaram mais dois dias secando ao ar e protegidos de intempéries.

\footnotetext{
29 "Preservación y secado del culmo de Guadua angustifolia Kunth".
} 
O local escolhido para tal atividade conforme combinado com a coordenação do Canteiro Experimental foi sob a cobertura do Canteiro Experimental, ao chão, sendo estes empilhados de maneira espaçada por meio de sarrafos de madeira transversais e uniformes que garantem a ventilação entre os colmos.

\subsubsection{1 - Armazenamento}

Entre o fim do processo de secagem e o início do processo de beneficiamento há um curto período de armazenamento. Para uma boa preservação de suas características naturais, os colmos ou suas seções devem ser alocados distante da umidade do solo, em locais arejados e protegidos da radiação solar. O armazenamento horizontal deve ser efetuado em uma altura máxima de 1,70 $\mathrm{m}$ e da mesma maneira que na secagem, os colmos devem estar separados por elementos transversais, sendo que quanto menor a altura do empilhamento, menor a possibilidade de esmagamento das peças.

Já no caso do armazenamento vertical, muito frequente nos tratamentos colombianos, os colmos ou seções devem ser encostados e intercalados lado a lado sobre um cavalete cuja altura deve ser ao menos $2 / 3$ da altura dos colmos. Suas extremidades deve estar isoladas do solo para evitar a absorção de umidade. Os colmos localizados na extremidade dos cavaletes devem ser amarrados para evitar deslizamentos.

No presente trabalho, após o período de secagem o armazenamento em curto espaço de tempo foi feito na mesma posição da secagem. O período foi somente o necessário para o prosseguimento do trabalho de beneficiamento e a conclusão do trabalho de execução das fundações.

\subsubsection{2 - Classificação}

Após a secagem dos colmos e antes da etapa de beneficiamento, foi realizada a classificação das peças originadas de acordo com o uso destinado, conforme item 4.2.1.7 sobre a subdivisão dos colmos. Assim, baseado no diâmetro das peças, na posição da peça no colmo (inferior/média/superior) e na espessura de parede do bambu foi feita a escolha das peças para cada função da estrutura (Figuras 145, 146, 147 e 148). 

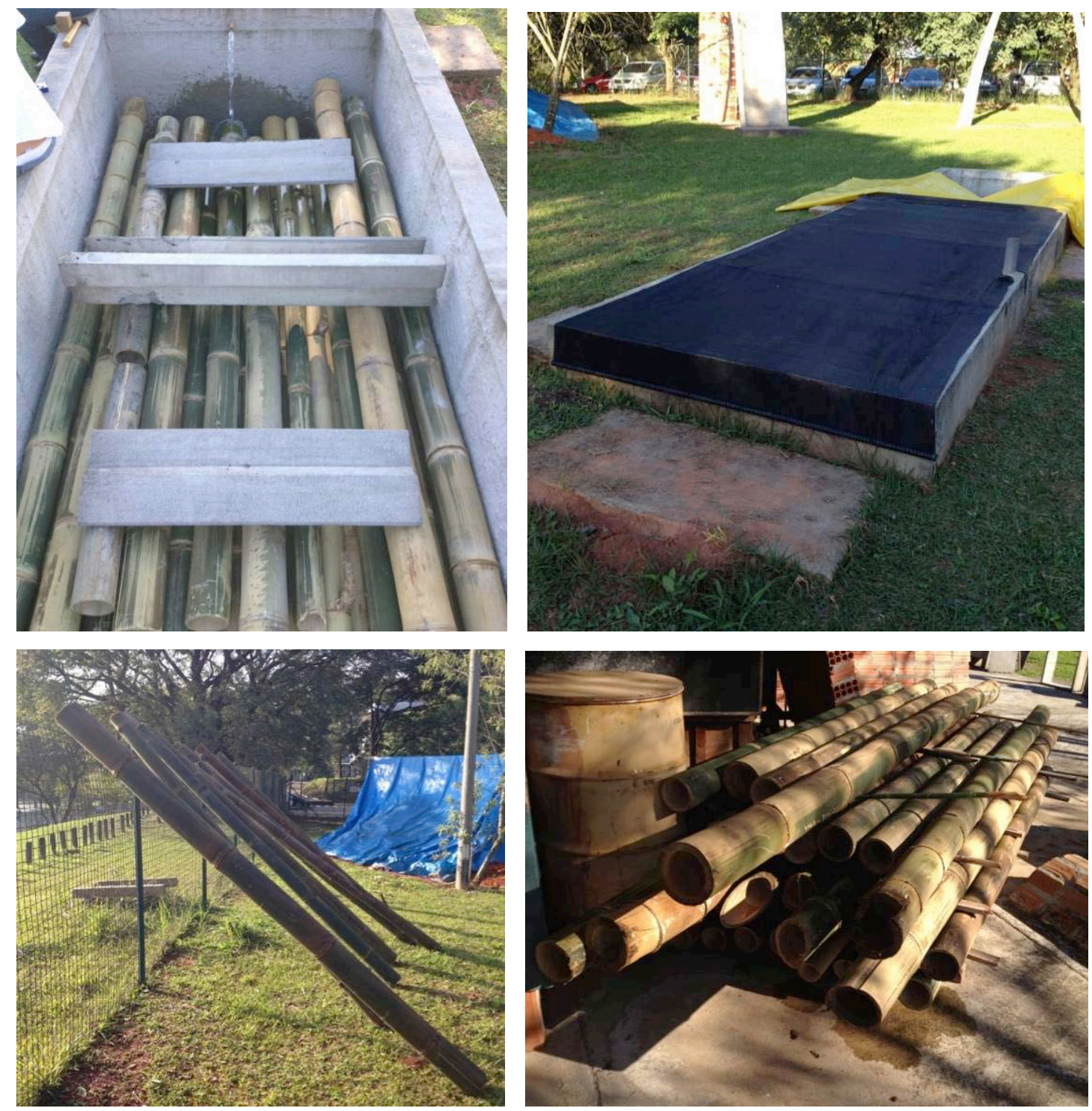

Figura 145, 146, 147 e 148 - Imersão das peças, proteção da solução, escorrimento e secagem das peças. Fonte: Autoria própria. 




Figura 149 - Classificação das peças pelo diâmetro.

Fonte: Autoria própria.

\subsubsection{3 - Beneficiamento do bambu}

O beneficiamento do bambu se deu em duas linhas, a do bambu para a estrutura, em $D$. giganteus, e a do bambu para vedação, em B. tuldoides. Na primeira delas, o bambu Dendrocalamus giganteus já se encontrava tratado e após a sua secagem passou pelo processo de seleção e nomeação de peças. Muitas delas não se encontram em perfeito estado já que o processo de secagem provocou algumas rachaduras. Com as peças escolhidas, foram marcadas as peças correspondentes aos 8 pilares $P 1$ (de 2,35 m) e aos 4 pilares P2 (de 2,50 m). Após isso as peças foram cortadas exatamente em tais medidas e eventuais brotos laterais também foram cortados e lixados.

Depois de cortadas no tamanho exato, as peças passaram pelo processo de selagem de sua superfície, através da aplicação de uma cera natural à base de carnaúba e cera de abelha $^{30}$. Também foram feitos testes de selagem da superfície do bambu com seladora de madeira e resina de poliéster. Ambos os produtos apresentaram bom resultado, melhorando a aparência natural do bambu, fechando suas fibras e protegendo-o. No entanto a escolha pela cera deu-se pela característica natural de seus componentes, além da possibilidade de fabricação própria do produto no contexto do projeto (Figuras 150, 151 e 152).

\footnotetext{
${ }^{30}$ Foi utilizada a cera da marca Ceras Mil, composta por carnaúba, cera de abelha, compostos parafínicos, impermeabilizante e diluentes orgânicos.
} 

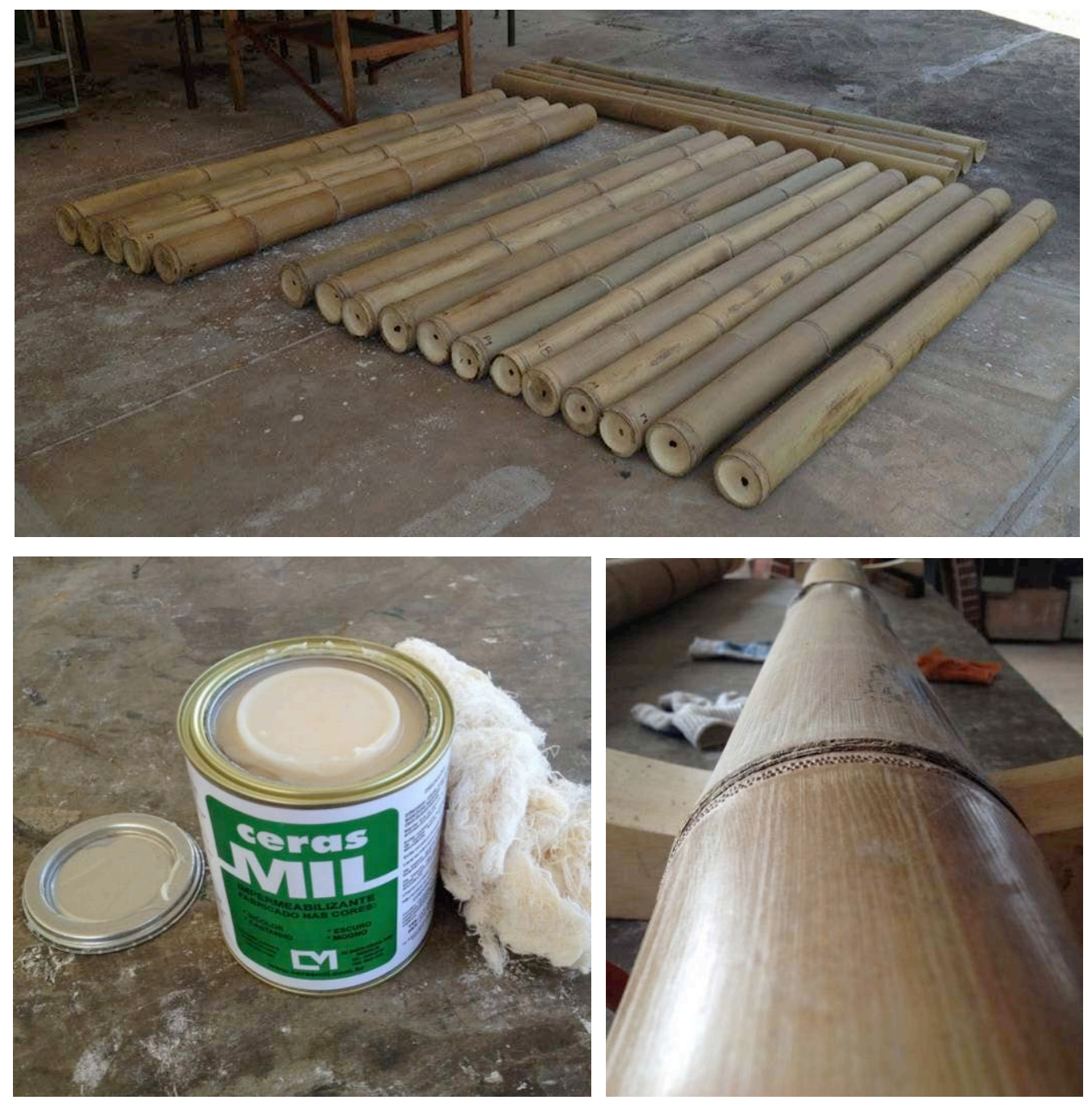

Figuras 150, 151 e 152 - Peças pré-fabricadas em bambu,

cera de carnaúba utilizada e peça de bambu com a cera aplicada.

Fonte: Autoria própria.

Já em relação ao $B$. tuldoides para vedação, seu beneficiamento deve ser feito em etapa anterior ao de tratamento, para que este seja mais eficaz. Primeiramente, os colmos de bambu foram cortados em serra circular ou serra de fita na largura desejada para o painel a ser executado. No caso, foram feitos dois painéis experimentais de 0,90 $\mathrm{m} \mathrm{X} \mathrm{0,90} \mathrm{m}$ e os painéis definitivos de $0,70 \mathrm{~m} \times 2,35 \mathrm{~m}$. Após o corte em partes menores, o bambu foi cortado longitudinalmente com uma faca radial, formando taliscas. Com as taliscas prontas, foi necessário retirar o parênquima existente na parte interna do bambu, talisca a talisca, com o uso de um facão. Após limpas, as taliscas foram tratadas pelo mesmo processo adotado para o bambu gigante, ou seja, tratamento de imersão em solução de octoborato. 
As taliscas ficaram três semanas na solução, passando depois para a secagem. Após esse beneficiamento, as taliscas ficaram prontas para a montagem de painéis de vedação.
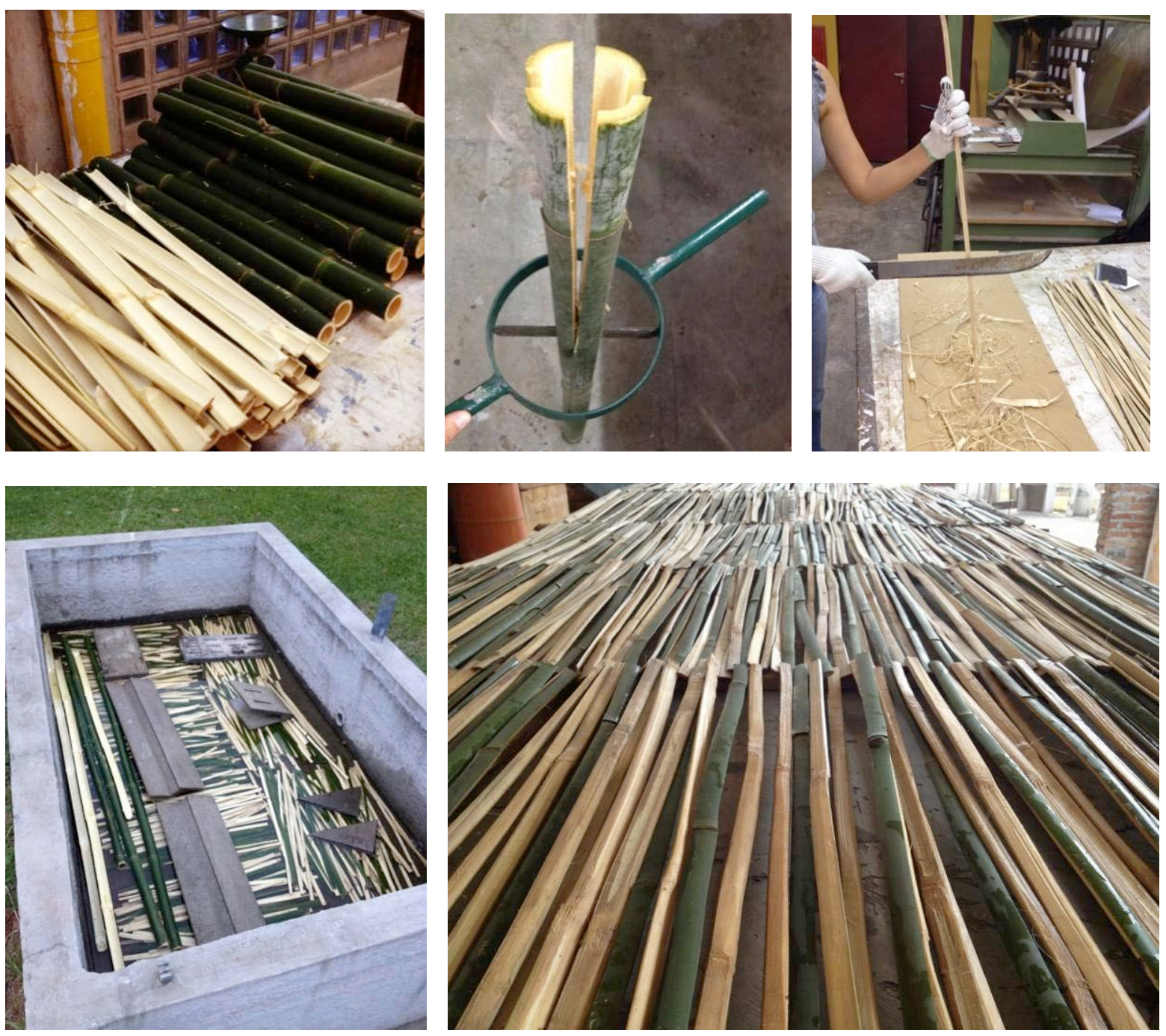

Figuras 153, 154, 155, 156 e 157 - Bambus em beneficiamento, corte de faca radial, retirada do parênquima, tratamento por imersão e secagem das taliscas.

Fonte: Autoria própria.

\subsubsection{4 - Locação e preparação do terreno e execução das fundações}

Concomitantemente ao beneficiamento dos bambus foi feita a preparação do terreno. Para a implantação adequada do protótipo, o terreno foi escavado para a execução da fundação rasa na forma de radier. Algumas raízes de árvores foram extraídas e o solo foi compactado manualmente para a acomodação da fôrma de madeira onde o concreto foi depositado. 

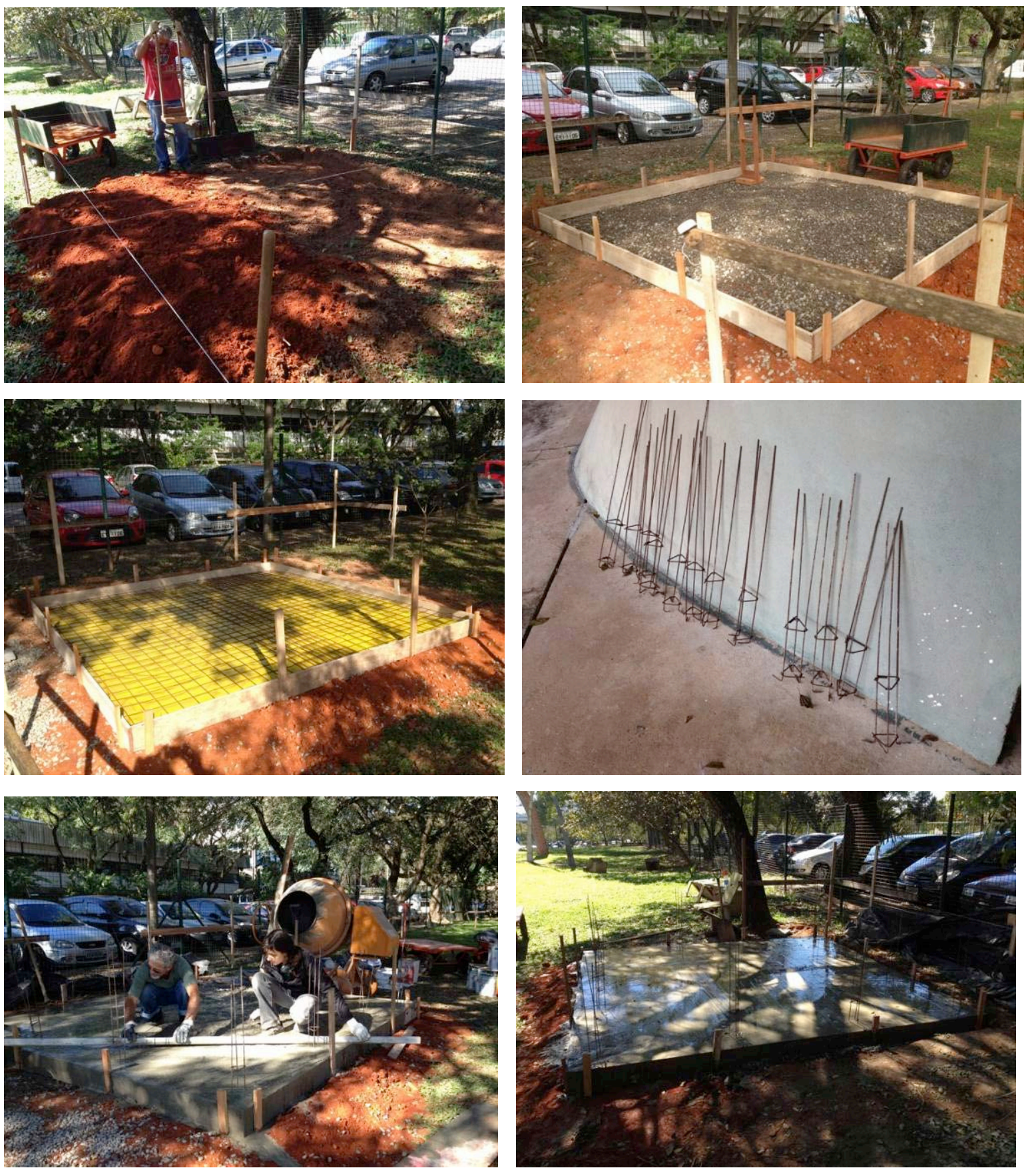

Figuras 158, 159, 160, 161, 162 e 163 - Nivelamento do terreno, fôrma com lastro de brita, lona plástica com malha metálica, ferragem dos arranques dos pilares, concretagem e radier finalizado .

Fonte: Autoria própria.

Após o posicionamento e o correto nivelamento da forma, foi aplicado um lastro de brita sobre a terra e uma lona plástica sobre a brita, com o intuito de evitar o contato da umidade do solo com o concreto. Telas de aço soldadas foram posicionadas na fôrma transpassando-se entre si sobre espaçadores. Arranques de espera para os pilares de bambu 
foram fixados na malha metálica, compostos por vergalhões e estribos triangulares. Com toda a armação montada, 1,35 m3 de concreto foram depositados na fôrma.

\subsubsection{5 - Execução do embasamento}

Para separar a estrutura de bambu do solo, resguardando-a de respingos e de contato com a umidade, o projeto previu a execução de um embasamento de alvenaria. Propôs-se então a utilização do bloco de terra comprimida (BTC ou tijolo ecológico) por utilizar-se do solo cru como matéria-prima, prática comum na região. Os blocos foram confeccionados com terra, areia e cimento e assentados como tijolos, com massa de assentamento na proporção entre areia e terra de 1:2, com o acréscimo de $6 \%$ de cimento. $\mathrm{O}$ processo de fabricação do BTC é feito com o auxílio de uma prensa mecânica. Foram utilizados 202 blocos de 12,5 cm X $25 \mathrm{~cm} \mathrm{X} 5 \mathrm{~cm}$ (Figuras 164 e 165).
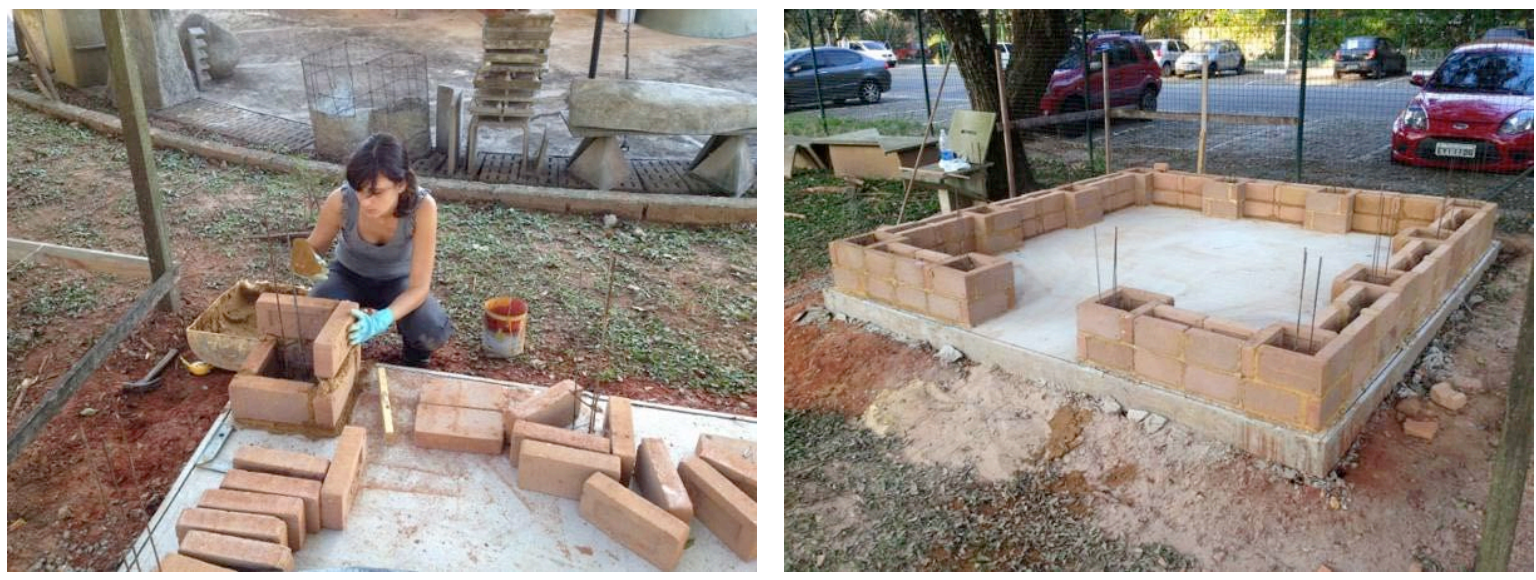

Figuras 164 e 165 - Assentamento do BTC e embasamento finalizado.

Fonte: Autoria própria.

\subsubsection{6- Execução da Estrutura}

Com as peças de bambu gigante já pré-dimensionadas e nomeadas, houve a necessidade de efetuar os últimos beneficiamentos para a perfeita execução da estrutura de bambu.

Primeiramente, com a correta medição de peças atenta à variabilidade dimensional ao longo do colmo do bambu, foram realizados os cortes das extremidades para os encaixes 
ortogonais entre as peças. Foi utilizada uma serra de fita, por sua disponibilidade no laboratório, mas tal procedimento também pode ser realizado com facão e serrote. Também foram executados orifícios de aproximadamente $5 \mathrm{~cm}$ com serra copo no primeiro entrenó inferior das peças correspondentes aos pilares, para a posterior inserção de graute quanto locadas corretamente e a consequente solidarização dos pilares com a fundação.

Também foi aplicado o graute em todas as conexões entre bambus, fazendo a junção das peças com barra roscada. Assim como a conexão de Simón Vélez, o intuito do procedimento é melhor distribuir os esforços solicitantes de tal conexão em toda superfície interna do bambu, prevenindo assim possíveis rachaduras provenientes dos orifícios das barras roscadas. Os orifícios na base do bambu foram fechados com a tampa extraída pela serra copo, coladas com uma mistura de serragem e cola branca.

Outra medida importante para evitar rachaduras nas peças de bambu constitui no emprego de abraçadeiras metálicas. Conforme a Figura 172, foram fixadas abraçadeiras metálicas nos pontos de maior solicitação com o intuito de propiciar maior rigidez às peças. 

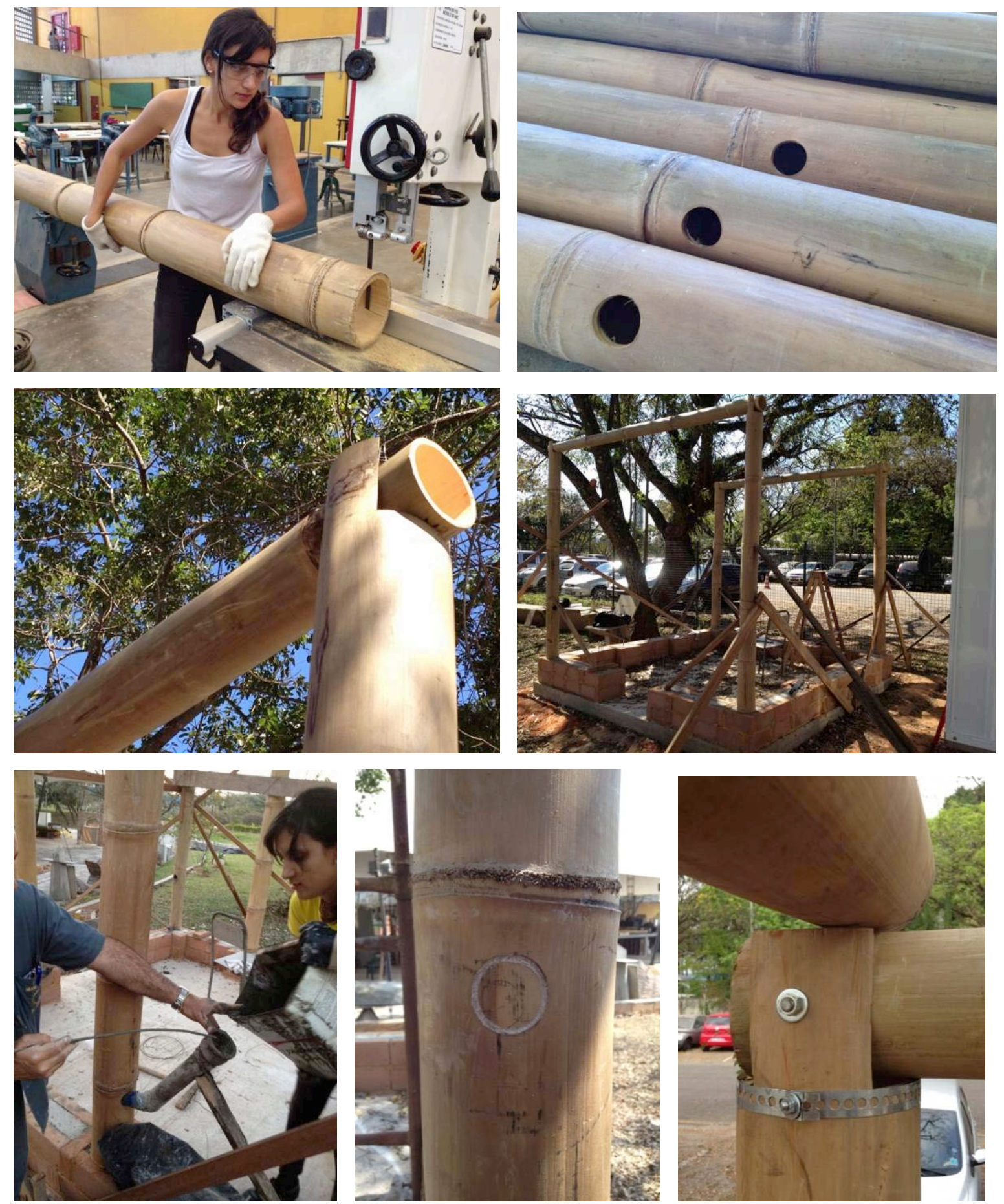

Figuras 166, 167, 168, 169, 170, 171 e 172 - Corte para encaixe de peças, orifícios feitos por serra copo, encaixe entre peças de bambu, locação dos primeiros pórticos, grauteamento dos bambus nas esperas, fechamento de orifícios com cola branca e serragem, braçadeiras metálicas evitando cisalhamento.

Fonte: Autoria própria. 




Figura 173 - Estrutura finalizada.

Fonte: Autoria própria.

\subsubsection{7 - Execução da vedação}

Os painéis diafragma de vedação, uma vez tendo seu material já beneficiado, são de fácil e rápida montagem. Foram feitos ensaios de dimensão menor $(0,90 \mathrm{~m} \times 0,90 \mathrm{~m})$ para posteriormente serem feitos os painéis maiores $(2,25 \mathrm{~m} \times 0,75 \mathrm{~m})$, conforme as especificações do projeto.

A montagem foi feita com o auxílio de um gabarito de compensado, que garantiu um maior controle sobre a regularidade da dimensão dos painéis e agilidade de montagem. $A$ trama foi composta por três eixos verticais de meia cana de $B$. tuldoides fixados em sanduíche de ripas de madeira de $5 \mathrm{~cm} \times 2 \mathrm{~cm}$, de forma que nenhum prego perfure diretamente as taliscas de bambu, prevenindo a ocorrência de rachaduras.

Após totalmente tramado, o painel recebeu em seu verso taliscas fixadas diagonalmente para garantir o contraventamento da peça. Tais taliscas foram previamente perfuradas com uma broca de pequeno diâmetro e amarradas com o auxílio de arame recozido. Sobre a trama de taliscas foi fixada uma tela de viveiro hexagonal composta por arame galvanizado e fixado com o auxílio de arame recozido. Os painéis foram fixados na estrutura através de braçadeiras metálicas para serem posteriormente argamassados. 

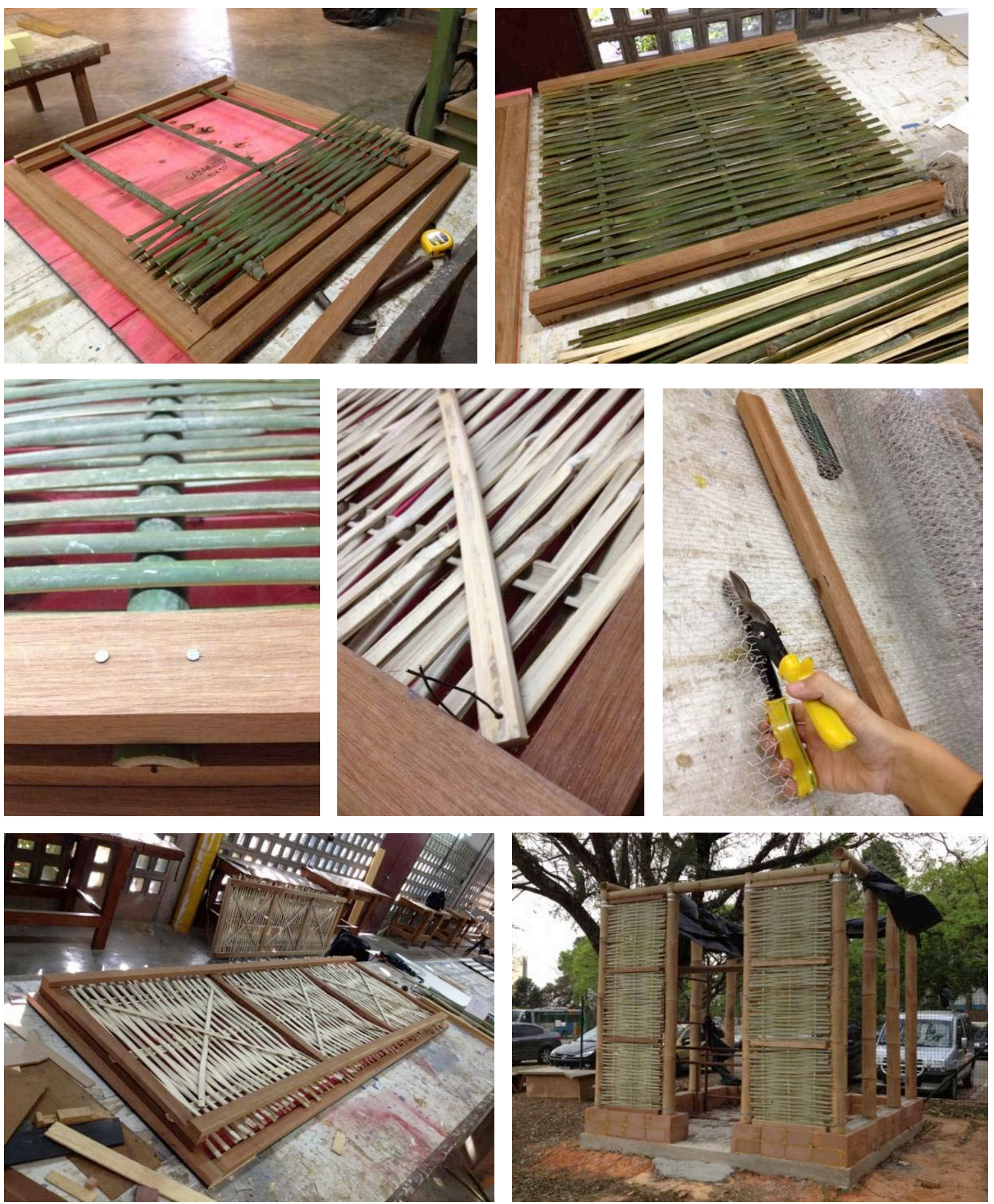

Figuras 174, 175, 176, 177, 178, 179 e 180 - Confecção dos painéis em gabarito, painel pequeno finalizado, detalhe fixação de taliscas sem perfuração, fixação do contraventamento dos painéis, tela de viveiro, painel grande finalizado e painéis fixados à estrutura. Fonte: Autoria própria. 


\subsubsection{8 - Argamassagem}

Nos painéis menores pôde-se ensaiar algumas soluções de argamassagem. Foram utilizadas dois tipos de reboco, um elaborado a partir de uma mistura de solo-cimento na proporção entre areia e terra de 1:2, com o acréscimo de $10 \%$ de cimento e outro elaborado somente com cimento e areia. Os painéis continuaram com a característica da leveza, no entanto a retração apresentada pelo solo-cimento leva a crer que a utilização de fibras naturais na mistura, como o sisal, melhoraria tal característica (Figuras 181 e 182).
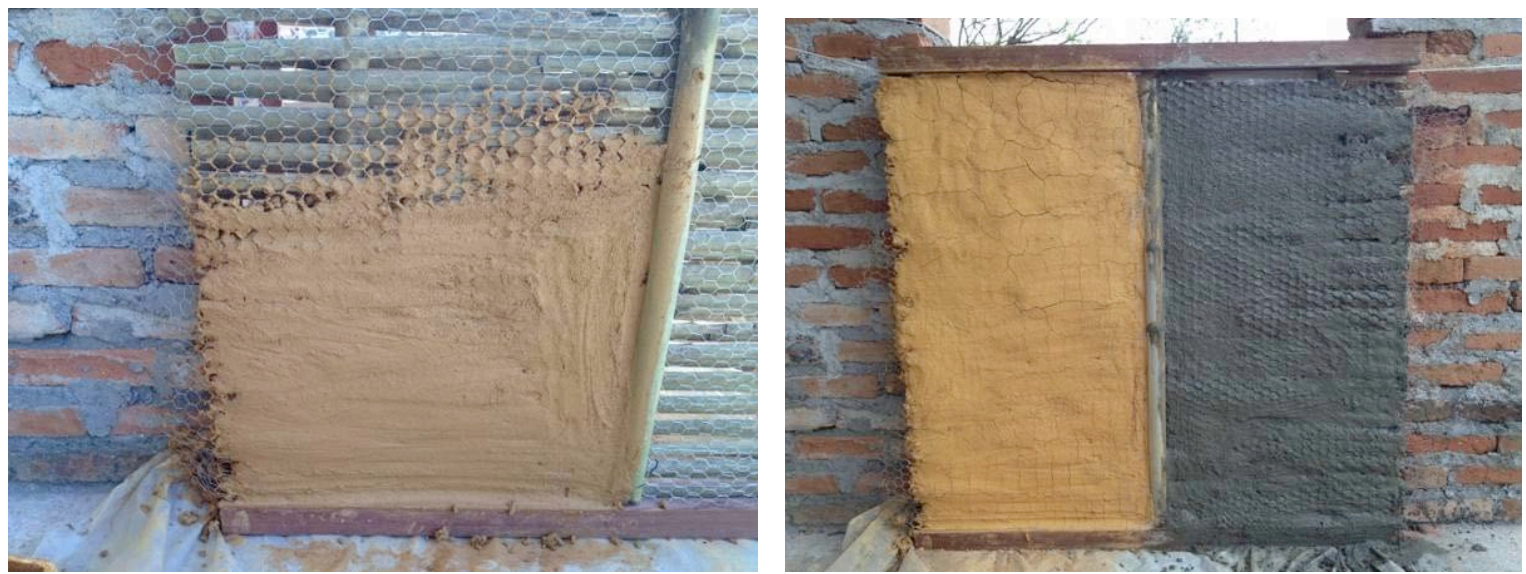

Figuras 181 e 182 - Argamassagem com solo-cimento e reboco simples em cimento.

Fonte: Autoria própria.

\section{3 - Resultados}

\subsection{1 - Resultado por etapas do processo}

O experimento realizado na pesquisa de mestrado possibilitou a geração de alguns resultados práticos que não existiriam somente com a avaliação da pesquisa qualitativa e com a elaboração do projeto. Como tal pesquisa científica visa uma aproximação prática com o contexto estudado do Vale do Ribeira, os resultados e conclusões provenientes deste processo são de grande contribuição, onde a execução do sistema construtivo foi feita por não profissionais na construção com o material. Os resultados são dispostos através de considerações sobre cada uma das etapas do processo e fundamentam as conclusões sobre o processo construtivo. 


\subsubsection{1 - Quanto ao processo de escolha dos colmos, corte e cura}

A subjetividade na escolha dos colmos trouxe alguma variação em relação à maturidade dos mesmos. Após secos, eram perceptíveis as diferenças em relação à coloração e, provavelmente, tal característica gere diferenças na resistência mecânica dos colmos. Há necessidade de aprofundamento das questões de reconhecimento e seleção dos colmos para garantir um uso consciente do material, e poder basear tal uso nas normas técnicas anteriormente citadas.

Quanto ao corte do bambu $D$. giganteus, tal procedimento exige uma certa experiência e habilidade no manejo da motosserra. Os colmos são extremamente pesados e de difícil manejo, sobretudo no momento de posicioná-los verticalmente sobre a superfície cimentada para o processo de cura na mata.

\subsubsection{2 - Quanto ao transporte, tratamento e secagem}

O transporte do material da mata até a oficina não apresentou grande problemas, uma vez que os colmos foram subdivididos e que havia disponibilidade de veículo motorizado para a tarefa. O processo de tratamento foi de simples execução, no entanto a comprovação de sua eficácia será somente feita em uma avaliação pós-ocupação da construção, na presença ou não de patologias construtivas no material bambu.

Já a secagem aparentemente não foi um processo totalmente bem-sucedido uma vez que o longo período de estiagem que a cidade de São Paulo passou na ocasião da execução do protótipo sujeitou os bambus a um clima de baixíssima umidade e altas temperaturas, provavelmente sendo um dos motivos de grande perda de colmos de $D$. giganteus por rachaduras. O ambiente do Vale do Ribeira apresenta uma maior umidade relativa do ar, podendo provavelmente serem obtidos melhores resultados neste quesito. De qualquer forma, um maior controle sobre a umidade e a temperatura do ambiente de secagem dos colmos provavelmente renderia melhores resultados ao experimento.

\subsubsection{3 - Quanto ao beneficiamento}

No caso do beneficiamento da vedação, a atividade inicialmente demanda tempo extenso no corte dos colmos, subdivisão em taliscas e limpeza do parênquima, mas conforme observado no processo, mediante treinamento, o dispêndio de tempo para tais atividades tende a reduzir-se consideravelmente. 
Já no beneficiamento da estrutura, no que diz respeito aos cortes, o processo não apresentou grande dispêndio de trabalho. Consistiu somente no corte de prédimensionamento, marcação e corte dos encaixes das peças. Quanto ao tratamento impermeabilizante, a aplicação da cera foi certamente mais trabalhosa do que se a seladora e verniz fossem escolhidos. Além disso, caso este processo fosse escolhido, estas poderiam ser aplicadas com pistola para pintura, otimizando ainda mais o tempo do procedimento.

\subsubsection{4 - Quanto às fundações e ao embasamento}

Não é mandatória a utilização da solução construtiva empregada para as fundações e embasamento. A proposta da fundação rasa em radier foi devido ao solo local nos terrenos alagadiços do Vale do Ribeira, mas certamente outras fundações rasas poderiam ser empregadas dependendo do terreno, como a viga baldrame, por exemplo.

O embasamento, proposto em BTC poderia ser substituído por outros blocos de terra crua como o adobe ou até mesmo tijolos de terra cozida, dependendo dos recursos locais existentes. O BTC apresentou grande facilidade e agilidade de assentamento, uma vez que suas dimensões são generosas e sua superfície porosa. Há a necessidade de cuidado no manejo das peças, pois apesar de grande resistência estrutural, o BTC possui baixa resistência à abrasão. Já a argamassa em solo-cimento utilizada para assentamento trouxe algumas dificuldades de coesão com os blocos pelo baixo teor de cimento utilizado.

\subsubsection{5 - Quanto à estrutura}

A estrutura pré-fabricada apresentou um excelente desempenho de montagem. Apesar da irregularidade natural dos colmos de bambu, o pré-dimensionamento de peças foi muito bem sucedido e a montagem da estrutura quase não necessitou ajustes de nivelamento e encaixe. As conexões feitas com barra roscada e graute foram de fácil execução e até o presente momento possibilitaram grande estabilidade à estrutura.

\subsubsection{6 - Quanto à vedação}

A vedação em taliscas de bambu demonstrou um excelente resultado em termos de resistência mecânica e flexibilidade. A superfície resultante da trama apresentou uma boa estabilidade, apresentando um bom plano para a fixação de uma tela metálica para argamassagem. É necessário contudo efetuar-se um estudo mais aprofundado das formas de arremate de tais painéis para otimizar a argamassagem de suas extremidades. 


\subsubsection{7 - Quanto à argamassagem}

A argamassagem certamente é a parte do processo que mais necessita desenvolvimento, no entanto, não foi o ponto principal do experimento desenvolvido. Certamente seriam necessários alguns ensaios específicos sobre a variedade de misturas passíveis de desenvolvimento, e o desempenho de cada uma delas a partir de seu uso. Podem ser avaliadas experiências com rebocos de cimento simples, de solo-cimento, de calfitice $^{31}$, e o emprego de outros aditivos na mistura da massa. 0 fato é que o reboco de solo-cimento testado no experimento apresentou mais fissuras do que o imaginado, mesmo após a aplicação de uma segunda camada, sendo necessária assim, uma maior experimentação da proporção cimento/solo/areia.

\subsection{2 - Conclusões}

Apesar de uma série de questões técnicas levantadas com o experimento realizado, a viabilidade construtiva da técnica desenvolvida em projeto foi comprovada. O processo realizado pode ilustrar algumas questões decisórias do processo produtivo e suas implicações imediatas.

Houve uma preocupação na elaboração de uma prática construtiva que não se distanciasse muito das práticas empregadas no local. Tal decisão manifestou-se sobretudo no desencadeamento dos elementos que estruturam o edifício: vigas, pilares, embasamento e cobertura, de forma que o material fosse apresentado à população com uma simples leitura, e para que somente posteriormente pudesse ser reelaborado de modo a sugerir configurações especiais mais sofisticadas.

Dentre as questões produtivas que puderam ser avaliadas no processo de execução do protótipo uma das mais relevantes foi a da mão de obra. O projeto foi desenvolvido de tal forma que não necessitasse de grandes equipamentos para a sua construção. No entanto, é de extrema valia que os procedimentos possam ser realizados com um número mínimo de trabalhadores. Grande parte das etapas construtivas necessitavam de um mínimo de duas pessoas, e mesmo tendo muitas delas passíveis de desenvolvimento com menos pessoas, o tempo de execução se reduza consideravelmente. Assim, equipes de trabalho, por menor que sejam, tendem a otimizar de maneira sensível a produtividade das construções.

\footnotetext{
${ }^{31}$ Calfitice é o composto feito à base de cal, fibras, tierra y cemento (em espanhol).
} 
Além da questão quantitativa da mão-de-obra, a questão qualitativa também pôde ser avaliada no procedimento. No caso, o trabalho foi executado por pessoas que não possuíam muita prática no manejo do bambu enquanto material de construção: eu, o aluno Gustavo de Oliveira e o técnico Romerito Ferraz. A assimilação do manejo foi muito em função de pesquisas previamente realizadas e de experimentação entre os envolvidos. Assim, a introdução de tais práticas construtivas não difundidas necessita uma formação da mão-de-obra mínima, uma vez que seus procedimentos não são tão evidentes.

Quanto à avaliação da eficiência das construções sob os aspectos de conforto, durabilidade e manutenção, há a necessidade de uma avaliação a ser feita a longo prazo, em sua pós ocupação, uma vez que a construção tem pouco tempo desde sua execução e ainda não foi possível analisar suas patologias.

Quanto às técnicas construtivas empregadas em cada parte do protótipo, é evidente que estas sub-etapas são por si só grandes áreas de pesquisa. Cada etapa necessita uma pesquisa mais ampla para que possa chegar à produção de novos conhecimentos acerca de construção em bambu e que garanta a consolidação do material mediante a comprovação de suas potencialidades. 


\section{CAPÍTULO 5 - CONSIDERAÇÕES FINAIS}




\section{1 - Conclusões}

Diante da presente experiência empírica dentro um universo de pesquisa ainda muito explorável, algumas premissas conclusivas foram levantadas como produto do trabalho, que podem nortear uma série de subtemas a serem investigados em trabalhos subsequentes.

Primeiramente, uma nova visão do tema da sustentabilidade, tão explorado atualmente. Pode-se concluir que é necessária uma abordagem mais sistêmica sobre o que de fato pode ser considerado sustentável. A avaliação deve possuir uma maior contextualização com seu universo, e não mais possuir uma abordagem tecnocrata e genérica que se aplica a situações tão distintas. É importante notar o quanto o envolvimento de parcelas da sociedade na busca por mudanças estruturais nos padrões do desenvolvimento é necessário para a efetividade de uma estratégia que aponte para a sustentabilidade. A sociedade deve possuir um maior poder de participação, para que tais ações sejam feitas de forma consciente, e que a responsabilidade das mesmas sejam atribuídas diretamente aos seus usuários. Neste contexto, as comunidade tradicionais já desempenham, no saber que lhes é legado, o exercício de equilíbrio entre a geração de insumos pela natureza e a manutenção da exploração de tais recursos, promovendo uma cultura autônoma que garantirá a preservação ambiental para suas próximas gerações.

Já em relação às culturas construtivas do Vale do Ribeira, pôde-se intuir na pesquisa a importância da integração do modo de vida do caiçara com a natureza. O uso cuidadoso dos recursos locais, a significativa manutenção da cultura construtiva local e a tradição das organizações de trabalho coletivas são consequência dessa articulação do usuário com seu meio. É importante que esta questão seja sempre um ponto de partida para o desenvolvimento de trabalhos que envolvam a população em seu processo. No caso do presente projeto, há o intuito de prosseguimento do trabalho iniciado em pesquisa com uma aplicação prática em projeto participativo no local pesquisado, e para isso, é necessário que os conceitos básicos do universo em questão estejam claramente apreendidos. Assim, a proposta de um sistema construtivo aplicável para a autoconstrução na região pode simbolizar uma importante contribuição para diversos aspectos da manutenção cultural de tal população.

Em relação à construção civil em bambu, pode-se afirmar que o material representa uma possível alternativa para uso na construção civil, inclusive para suprir a carência de habitação de interesse social no Brasil. É um material com excelente potencial construtivo, alto rendimento material, baixíssimo custo e perfeita adaptação ao nosso clima. Resta sobretudo consolidar uma cultura construtiva no país, que ao que foi constatado na pesquisa, ainda é muito inexpressiva. É necessária a continuidade em ensino, pesquisa e 
prática da construção civil em bambu em nosso país, para que esta possa ser uma alternativa real, viável e crível no meio da construção civil nacional.

É necessária a busca de referências a programas e projetos bem-sucedidos de construção civil em bambu, como os analisados no presente trabalho, para que suas metodologias possam servir como ponto de partida para novos trabalhos. O material bambu possui grande potencial para uso em arquitetura emergencial assim como para projetos que visem suprir uma grande demanda habitacional. É necessário o estabelecimento de vínculos de tais projetos com as políticas públicas de habitação local, para que possam ser efetivos. Também faz-se necessário o acompanhamento de tais projetos, sua inserção junto à comunidade local, até os resultados recentes da pós-ocupação de tais iniciativas.

Outro importante questionamento que deve-se levar em consideração na elaboração de projetos de habitação com materiais alternativos diz respeito ao processo de aprendizado tecnológico. É preferível que uma nova tecnologia não seja simplesmente sujeita ao processo de transferência direta à comunidade que seja aplicada. Mas sim, que essa apropriação seja feita dentro de um contexto onde haja espaço para uma nova visão, ou uma releitura de uma técnica ou material que já faz parte da cultura construtiva local. Dessa forma, há no processo de apropriação um status de formação, e não apenas de capacitação técnica, sendo assim muito mais fértil para a consolidação do aprendizado como forma de trabalho regular.

À parte dessas questões, a implementação de um processo construtivo em bambu certamente contempla muitos aspectos positivos sob as perspectivas:

1. Sociais:

- Com a provisão de uma habitação digna e de qualidade;

- Com a criação de oportunidade de emprego para população na manufatura e na produção rural de bambu.

2. Econômicas:

- Com a necessidade de pequeno investimento inicial;

- Com o baixo custo de produção da matéria-prima;

- Com o baixo custo de manufatura;

- Com o baixo custo de transporte.

3. Produtivas: 
- Com a racionalização da produção pela pré-fabricação e pouco desperdício de material;

- Com a simplicidade de equipamentos necessários no processo produtivo;

- Com a simplicidade da produção, possibilitando o funcionamento da fábrica independentemente do tamanho da demanda;

- Com a facilidade e rapidez na montagem.

4. Ambientais:

- Com a intensificação do cultivo do bambu e o estímulo à reabilitação de florestas degradadas;

- Com a promoção de uma boa gestão do uso do bambu;

- Com a configuração de um processo de construção não poluente;

- Com o uso de materiais locais.

Apesar de todos os aspectos positivos da promoção do uso do material em programas de habitação, é necessária atenção especial ao projeto arquitetônico. 0 desenvolvimento incorreto do projeto pode ser responsável por uma má utilização do material, que pode acarretar em uma ineficiência em sua vida útil ou até uma subutilização do potencial estrutural que o material bambu oferece. Além disso é necessária uma atenção especial à velocidade de reposição natural de matéria-prima, ou seja, é necessário um plano de manejo sustentável para o uso do bambu, para que tais programas não signifiquem uma ameaça à existência de tais espécies.

Quanto à premissas levantadas sobre a experimentação construtiva com o bambu realizada na pesquisa, a viabilidade construtiva do projeto foi comprovada. A mão-de-obra para o desenvolvimento do processo aparentou ser viável mesmo sem especialidade no assunto. Dependendo da formação, a técnica construtiva pode ser facilmente executada e difundida entre seus usuários. Quantitativamente, a mão-de-obra não necessita de grande volume de trabalhadores e o processo apresenta grande produtividade.

Estabelecidas tais premissas conclusivas resultantes da presente pesquisa, há alguns importantes considerações finais a serem pontuadas para a legitimidade de tal pesquisa. Primeiramente é necessário considerar que o presente trabalho é uma pequena contribuição em pesquisa tecnológica no universo da arquitetura e da construção, dentro de 
um imprescindível contexto social, político e econômico que não pode ser desconsiderado. Assim sendo, é necessário enfatizar que a inovação tecnológica em si nunca será responsável por resoluções de questões de sustentabilidade em nossa sociedade. É necessário que tais pesquisas, vinculadas ao Estado mediante à elaboração de políticas públicas e com a contribuição da participação popular, sejam articuladas na busca de resoluções práticas à problemáticas como a descrita no trabalho. É necessária uma articulação entre as mais diversas escalas de poder público, para que o projeto, na pequena escala estudada, possa ser de fato colocado em prática, pois não há sustentabilidade em um contexto onde há ilegalidade.

\section{3 - Perspectiva para pesquisas futuras}

A presente pesquisa científica representa importante contribuição para a afirmação do bambu enquanto alternativa material efetiva na construção civil. Trazer a discussão sobre a efetividade do emprego de tal material e sua cultura construtiva no ambiente científico da Faculdade de Arquitetura e Urbanismo da USP representa um importante trabalho de articulação em um domínio pouco explorado. No entanto, o objetivo principal é trazer o tema ao debate, não fazendo-se esgotar as possibilidades de discussão no meio acadêmico, pelo contrário, gerando insumos para uma discussão com maior embasamento e para o prosseguimento de pesquisas científicas.

Assim, algumas das linhas de pesquisas que possivelmente podem ser exploradas dentro de tal universo são:

1. Políticas públicas voltadas à produção de espaços sustentáveis.

2. Legislação para o uso do bambu na construção civil no Brasil.

3. Sistemas e conexões em bambu: análise qualitativa e desempenho mecânico.

4. Tratamentos preservativos do bambu: análise qualitativa.

5. Ciclo de vida útil do bambu.

6. Analise do conceito de energia incorporada (EI) do bambu.

7. Produção industrial: certificação de sustentabilidade na cadeia produtiva do bambu.

8. Produção industrial: subprodutos do bambu. 


\section{BIBLIOGRAFIA}

AACHEN UNIVERSITY, FACULTY OF ARCHITECTURE - CONSTRUCTION WITH BAMBOO. Disponível em: <http://bambus.rwth-aachen.de/>. Consultado em: 22/07/2011.

ALMEIDA, P. Usos e Costumes Praianos. In: Enciclopédia caiçara: História e memória caiçara vol.4; DIEGUES, A. C. S.; FORTES FILHO, P. (org.) São Paulo: HUCITEC/NUPAUB/CEC/USP, 2005, p. 45-60.

AMIMA - ARQUITETURA DE MÍNIMO IMPACTO SOBRE O MEIO-AMBIENTE. Disponível em: <http://www.amima-arquitetura.com/>. Consultado em: 12/07/2011.

ANNA HERINGER. Disponível em: <www.anna-heringer.com>. Consultado em: 20/08/2012.

APUAMA. Disponível em: <http://www.apuama.org/> . Consultado em: 18/06/2012.

ARCPROSPECT - INTERNATIONAL FOUNDATION OF ARCHITECTS AND DESIGN PROFESSIONALS. Disponível em: <http://www.arcprospect.org/>. Consultado em: 22/08/2012.

ASSOCIAÇÃO BRASILEIRA DE NORMAS TÉCNICAS - ABNT. Rio de Janeiro. NBR 7190/97 Projeto de estruturas de madeira, 1997.

ASSOCIAÇÃO BRASILEIRA DE NORMAS TÉCNICAS - ABNT. Rio de Janeiro. NBR 1575-1 Edifícios habitacionais de até cinco pavimentos, 2008.

BAMBOO CENTRAL - BAMBOO, PEOPLE AND ENVIRONMENT. Disponível em: $<$ http://www.bamboocentral.org/>. Consultado em: 14/07/2011.

BAMBOO LIVING - BAMBOO PREFAB HOMES. Disponível em: <http:// www.bambootechnologies.com/>. Consultado em: 14/07/2011.

BARBIRATO, G. M.; CARDOSO, R.; SARTORI, E. M.; MARTINS, J. C.; SANTOS, R. G.; OITICICA, M. L. G. Condições de conforto térmico da primeira unidade habitacional de interesse social brasileira construída em bambu: Maceió, AL. In: ENCONTRO NACIONAL DE TECNOLOGIA DO AMBIENTE CONSTRUÍDO, 10., 2004,São Paulo. Anais... São Paulo: ANTAC, 2004.

BARDI, L. B. Tempos de grossura: o design no impasse - coord. Marcelo Suzuki, São Paulo: Instituto Lina Bo e P.M. Bardi, 1994.

BARELLI, B. G. P. Design para a sustentabilidade : modelo de cadeia produtiva do bambu laminado colado (BLC) e seus produtos. Dissertação de Mestrado - Faculdade de Arquitetura, Artes e Comunicação, Universidade Estadual de São Paulo. Bauru, 2009. 
BESS, N. Bamboo in Japan. Tokio: Kodansha International, 2001.

BIBLIOTECA CF+S - CIUDADES PARA UN FUTURO MÁS SOSTENIBLE. Disponível em: $<$ http://habitat.aq.upm.es/>. Consultado em: 23/08/2012.

CAMACHO REYES, V.; PÁEZ RAMOS, I. Estudio de conexiones en Guadua solicitadas a momento flector. Trabajo de grado. Facultad de Ingeniería, Universidad Nacional de Colombia. Bogotá, 2002.

CANTOS DE TRABALHO - MUTIRÃO. Produção e Direção: L. Hirszman. Montagem: R. Soares. 1974. Duração 13'. Vídeo em alta resolução restaurado digitalmente a partir do reversível original. Produzido pelo Ministério da Educação e Cultura.

CARDOSO, R. Arquitetura com Bambu. Dissertação de Mestrado em Arquitetura - Convênio Universidade para o desenvolvimento do Estado e da Região do Pantanal e Universidade Federal do Rio Grande do Sul. Porto Alegre, 2000.

CMMAD - Comissão Mundial sobre Meio Ambiente e Desenvolvimento. Nosso futuro comum, 2a Edição. Rio de Janeiro : Fundação Getúlio Vargas, 1991.

COOPERACIÓN COLOMBO-ALEMANA. Guía para la Autoconstrucción utilizando guadua como elemento principal. Bogotá: Edición JM Calle, 2000.

COLARTE - EL ARTE EM COLOMBIA. Disponível em: <http://www.colarte.com/>. Consultado em: 23/08/2012.

DEAN, A. O.; HURSLEY, T. Rural Studio: Samuel Mockbee and an architecture of decency New York : Princeton Architectural Press, 2002

DETHIER, J.; STEFFENS, K. Grow Your Own House: Simón Vélez and Bamboo Architecture. Weil am Rhein: Vitra Design Museum, 2000.

DELGADO, C. P. O. Paneles Estructurales con laminas de Guadua. Trabajo de grado. Facultad de Artes, Universidad Nacional de Colombia. Bogotá, 2000.

DIEGUES, A. C. S. Desenvolvimento sustentável ou sociedades sustentáveis: da crítica dos modelos aos novos paradigmas. Revista São Paulo em Perspectiva, n.1-2, jan./julho 1992.

. Sociedades e comunidades Sustentáveis. São Paulo, 2002. Disponível em: http://www.usp.br/nupaub/. Consultado em: 13/03/2010.

; FORTES FILHO, P. (org.). Enciclopédia caiçara: O olhar do pesquisador vol.1 - São Paulo : HUCITEC/NUPAUB/CEC/USP, 2005 a. 
; FORTES FILHO, P. (org.). Enciclopédia caiçara: História e memória caiçara vol.4 São Paulo : HUCITEC/NUPAUB/CEC/USP, 2005 b.

Esboço de história ecológica e social caiçara. In: Enciclopédia caiçara : História e memória caiçara vol.4; DIEGUES, Antônio Carlos Sant'Anna; FORTES FILHO, Paulo (org.) São Paulo : HUCITEC/NUPAUB/CEC/USP, 2005 c.

DIESTE, E. Eladio Dieste: 1943-1996. Montevideo: Junta de Andalucia, 1997.

ECOBAMBOO - Disponível em: <http://www.ecobamboo.net/>. Consultado em: 22/07/2011.

FATHY, H. Construindo com o Povo, Rio de Janeiro: Editora Salamandra, USP, 1980.

FERRO, S. Arquitetura e trabalho livre. São Paulo: Cosac Naify, 2006.

FREIRE, P. Pedagogia da Autonomia: saberes necessários à prática educativa. São Paulo: Paz e Terra, 1996.

FSC Brasil. Conselho de Manejo Florestal. Disponível em: <http://www.fsc.org.br/>. Consultado em 15/07/2012.

GAUZIN-MÜLLER, D. Arquitetura Ecológica. São Paulo: Editora Senac, 2011.

GOVERNO DO ESTADO DE SÃO PAULO. Sistema ambiental paulista. Disponível em: $<$ http://www.ambiente.sp.gov.br/> . Consultado em 07/06/2010.

GUADUA BAMBOO - Guadua Bamboo Costa Rica Nurseries, Plantation Management and Consultancy. Disponível em: <http://www.guaduabamboo.com/>. Consultado em: 21/06/2011.

GUTIERREZ, J.A. Structural adequacy of traditional bamboo housing in Latin America. INBAR Technical Report no. 19. Beijing: INBAR, 2000.

HELD, Christian; MANZANO, Dari. El sector productivo y El mercado regional de La Guadua en El eje cafetero. INBAR, 2004. Disponível em: www.inbar.int.

HIDALGO-LÓPEZ, O. Bamboo the gift of the gods. Bogotá: D’vinni Ltda., 2003.

Manual de Construcción com bambu. Construcción Rural - 1. Bogotá: Estúdios Técnicos Colombianos Ltda., 1981.

INSTITUTO BRASILEIRO DE GEOGRAFIA E ESTAtístICA - IBGE. Censo Agropecuário 1995/1996. Brasília. 1996. 
INSTITUTO BRASILEIRO DE GEOGRAFIA E ESTATÍSTICA - IBGE. Disponível em: <http://www.ibge.gov.br/home/>. Consultado em: 20/03/2010

INSTITUTO COLOMBIANO DE NORMAS TÉCNICAS Y CERTIFICACIÓN - ICONTEC. Bogotá. NTC 5300 - Cosecha y Poscosecha de los culmos de Guadua angustifolia Kunth, 2008.

INSTITUTO COLOMBIANO DE NORMAS TÉCNICAS Y CERTIFICACIÓN - ICONTEC. Bogotá. NTC 5301 - Preservación y secado del culmo de Guadua angustifolia Kunth, 2007.

INSTITUTO COLOMBIANO DE NORMAS TÉCNICAS Y CERTIFICACIÓN - ICONTEC. Bogotá. NTC 5407 - Uniones de estructuras con Guadua angustifolia Kunth, 2006.

INSTITUTO PARA DESENVOLVIMENTO SUSTENTÁVEL E CIDADANIA NO VALE DO RIBEIRA IDESC. Registro. Conferência microrregional de desenvolvimento sustentável do Vale do Ribeira, 2006. Disponível em: < http://www.idesc.org.br/>. Consultado em: 09/08/2008.

INTERNATIONAL NETWORK FOR BAMBOO AND RATTAN - INBAR. VHC. Transfer of technology model (TOTEM) - Low cost bamboo based houses, 2002.

INTERNATIONAL NETWORK FOR BAMBOO AND RATTAN - INBAR. Disponível em: <http://www.inbar.int/>. Consultado em: 03/03/2011

INTERNATIONAL STANDARDIZATION ORGANIZATION - ISO. ISO N313 - Bamboo Structural Design, 2004.

JANSSEN, J. Building with bamboo. A handbook. Warwickshire: ITDG Publishing , 1995.

Designing and building with bamboo. In: INTERNATIONAL NETWORK FOR BAMBOO AND RATTAN (INBAR). Technical report. n. 20. Beijing, 2000.

JORGE, L. A. O espaço seco - Imaginário e poéticas da arquitetura moderna na América. Tese de Doutorado - Faculdade de Arquitetura e Urbanismo, Universidade de São Paulo. São Paulo, 1999.

KENNEDY, J. Building without borders: sustainable construction for the global village. Gabriola Island, Canadá: New Society Publishers, 2004.

LAYRARGUES, P. P. A cortina de fumaça: o discurso empresarial verde e a ideologia da racionalidade econômica. São Paulo: Annablume, 1998.

LENGEN, J. V. The barefoot Architect. A handbook for Green Building. California: Shelter Publications, 2008.

LIMA, J. F. Escola Transitória - Modelo Rural. Brasília: MEC/CEDATE, 1984. 
LUGT, P.; DOBBELSTEEN, A.; JANSSEN, J. An environmental, economic and practical assessment of bamboo as a building material for supporting structures. Construction and Building Materials. n.20, p. 648-656, 2006.

MARÇAL, V. H. S. Uso do bambu na construção civil. Projeto final em Engenharia Civil e Ambiental. Faculdade de Tecnologia, Universidade de Brasília. Brasília, 2008.

MARCELO VILLEGAS. Disponível em: <http://www.marcelovillegas.com/>. Consultado em: 20/08/2012.

MEADOWS, D. H. The limits to growth. New York: Universe Books, 1972.

MOIZES, F. A. Painéis de Bambu, uso e aplicações: uma experiência didática nos cursos de Design em Bauru, São Paulo. Dissertação de Mestrado - Faculdade de Arquitetura, Artes e Comunicação; Universidade Estadual de São Paulo. Bauru, 2007.

MOLINA, A. L. ; SOTO, P. A. Empleo simultaneo de guadua con madera en la construcción de vivienda. Especialização em Tecnologia - Facultad de Artes, Universidad Nacional de Colombia. Bogotá, 2002.

MONTOYA A., Jorge Augusto. Investigación Tecnológica en Métodos para la Preservación de la Guadua angustifolia Kunth. Tesis de Maestria en Medio Ambiente y Desarrollo Universidad Nacional de Colombia. Manizales, 2002.

MORADO, D. Material de fibra. In: Téchne, n.9, p.32-36, mar/abr. São Paulo: Editora Pini, 1994.

MÜLFARTH, R. K. Arquitetura de baixo impacto humano e ambiental. Tese de Doutorado Faculdade de Arquitetura e Urbanismo, Universidade de São Paulo. São Paulo, 2002.

MÜLLER, N. L. Uma vila do litoral paulista - Icapara. In: Enciclopédia caiçara : História e memória caiçara vol.4; DIEGUES, A. C. S.; FORTES FILHO, P. (org.) São Paulo : HUCITEC/NUPAUB/CEC/USP, 2005, p.99-106.

MY OPERA. Disponível em: <http://www.my.opera.com/ perfeito/albums> . Consultado em: $18 / 06 / 2011$

NASCIMENTO, E. P.; VIANA, J. N. (org.). Dilemas e desafios do desenvolvimento sustentável no Brasil. Rio de Janeiro: Garamond, 2009.

NATIONAL PALACE MUSEUM - TAPEl. Disponível em: <http://www.npm.gov.tw/>. Consultado em: 18/06/2011 
NOGUEIRA, C. L. Painel de bambu laminado colado estrutural. Dissertação de Mestrado Escola Superior de Agricultura "Luiz de Queiroz", Universidade de São Paulo. Piracicaba, 2008.

NÚCLEO DE APOIO À PESQUISA SOBRE POPULAÇÕES HUMANAS EM ÁREAS ÚMIDAS BRASILEIRAS - NUPAUB. Disponível em: <http://www.usp.br/nupaub/>. Consultado em: 20/06/2008.

NUNES, A. R. S. Construindo com a natureza bambu: uma alternativa de ecodesenvolvimento. Dissertação de Mestrado - Programa regional de desenvolvimento e meio ambiente, Universidade Federal de Sergipe. São Cristóvão. Sergipe, 2005.

OLIVEIRA, E. G. Bambu. Investigação de novos empregos na construção civil. Dissertação de Mestrado - Faculdade de Arquitetura e Urbanismo, Universidade de São Paulo. São Paulo, 1980.

OLIVEIRA, T. F. C. S. Sustentabilidade e arquitetura: uma reflexão sobre o uso do bambu na construção civil. Dissertação de Mestrado - Centro de Tecnologia, Universidade Federal de Alagoas. Maceió, 2006.

ORGANIZAÇÃO DAS NAÇÕES UNIDAS - ONU. Nosso futuro comum. Comissão Mundial Sobre Meio Ambiente e Desenvolvimento. Rio de Janeiro: Ed. FGV, 1988.

ORGANIZAÇÃO DAS NAÇÕES UNIDAS PARA A EDUCAÇÃO A CIÊNCIA E A CULTURA UNESCO. Disponível em: <http://www.unesco.org/>. Consultado em: 15/04/2011

PEREIRA, F. ; PEREIRA, A. ; SZUCS, C. A. ; PERES, L.; SILVEIRA, L. Características da habitação de interesse social na Região de Florianópolis: desenvolvimento de indicadores para melhoria do setor. In: Coletânea HABITARE, v.1. Porto Alegre: ANTAC, 2003.

PEREIRA, M. A.; BERALDO, A. L. Bambu de corpo e alma. Bauru, SP: Canal 6, 2008.

PEREIRA, M. A.; CARRARA, H. B.; BESSA, R. L.; LEITE, M. M. Utilização de painéis em bambu para fechamento de moradias. Artigo apresentado no CIMAD 11 - 10 Congresso IberoLatino-americano da Madeira na Construção, 7-9/06/2011, Coimbra, 2011.

PIMENTEL, M. A. As potencialidades de inserção do bambu no sistema produtivo no Brasil. Rio de Janeiro: UFF, 1997.

PROJETO BAMBU. Disponível em: <http://projetobambu.com/>. Consultado em: $15 / 07 / 2012$.

PROMOCCIÓN, INOVACCIÓN Y DESARROLLO INDUSTRIAL DE LA GUADUA. Disponível em: $<$ http://bambooguadua.com/>. Consultado em: 14/07/2011 
REDCLIFT, M. Sustainable Development. Exploring the contradictions. Londres, Nova York: Methuen. 1987.

SACHS, I. Ecodesenvolvimento: crescer sem destruir. São Paulo : Vértice, 1986.

Caminhos para o desenvolvimento sustentável. Rio de Janeiro: Garamond, 2009.

SALAS, E. D. Actualidad y Futuro de la Arquitectura de Bambú en Colombia. Simón Vélez: Símbolo y Búsqueda de lo Primitivo. Tesis de Doctorado - Escuela Tecnica Superior de Arquitectura de Barcelona. Universidad Politecnica de Cataluña. Barcelona, 2006.

SALDANHA, I. R. R. Espaços, recursos e conhecimento tradicional dos pescadores de manjuba (Anchoviella lepidentostole) em Iguape/SP - Dissertação de Mestrado - Programa de Pós-Graduação em Ciência Ambiental, Universidade de São Paulo. São Paulo, 2005.

SÁNCHEZ, A. L.; TOLE, M. A. Sistema pre-fabricado en Guadua para Vivienda de Interés Social. Trabajo de grado - Facultad de Artes, Universidad Nacional de Colombia. Bogotá, 2008.

SEBÁ, J. M. Sistema normalizado en guadua y madera: tecnologías apropiadas para la región cento occidental colombiana. Premio Corona a la arquitectura. Bogotá, 1986

SERRA, G. G. - Pesquisa em Arquitetura e Urbanismo. São Paulo: EDUSP/Mandarim, 2006.

SILVA, L. G. História caiçara e ciências sociais no Brasil. In: Enciclopédia caiçara : História e memória caiçara vol.4; DIEGUES, A. C. S.; FORTES FILHO, Paulo (org.) São Paulo : HUCITEC/NUPAUB/CEC/USP, 2005. p.15-28.

SILVA, M. M. C. P.; BARBOZA, A. S. R.; BARBIRATO, J. C. C. Avaliação do uso de bambu como material alternativo para a execução de habitação de interesse social. Ambiente Construído, Porto Alegre, v. 8, n. 1, p. 115-129, 2008.

SOUZA, A. P. C. C. Bambu na Habitação de Interesse Social no Brasil. Cadernos de Arquitetura e Urbanismo. Belo Horizonte/MG: Editora PUC Minas, v. 11, n. 12, p. 217-245, 2004.

S.O.S. RIBEIRA. Disponível em: <http://www.sosribeira.org.br/>. Consultado em:17/05/2010

STAMM, J. Guía para la construcción de puentes en Guadua. Proyecto Universidad Tecnologica de Pereira - (UTP-GTZ). Pereira, 2001. CD-ROM.

TAIPA DE MÃO, CASA DE CABOCLO. Direção e roteiro: L. B. Netto. Produção: R. M. Pan e S. Cordeiro. Pesquisa: S. Cordeiro.Imagens: A. Gonçalves e L. B. Netto Edição: C. Bueno. 
Coordenador do Projeto: Prof. Dr. C. Z. Costa. 1998. Duração 19'. Produzido por VideoFAU FAU USP.

TEIXEIRA , A. A. Painéis de Bambu para Habitações Econômicas: Avaliação do Desempenho de Painéis Revestidos com Argamassa. Dissertação de Mestrado - Faculdade de Arquitetura e Urbanismo, Universidade de Brasília. Brasília, 2006.

TODO ARQUITECTURA. Disponível em: <http://www.todoarquitectura.com/>. Consultado em: 15/07/2012.

UNITED NATIONS. Disponível em: <http://www.un.org/>. Consultado em: 25/06/2012.

UNIVERSIDADE FEDERAL DE MINAS GERAIS. Disponível em: <https://www.ufmg.br/>. Consultado em: 15/07/2012.

VALENTIN, A. De mares a alagados: a vida de caiçaras, caboclos e libertos no Vale do Ribeira (1800-1880) In: Enciclopédia caiçara: História e memória caiçara vol.4; DIEGUES, A. C. S.; FORTES FILHO, P. (org.) São Paulo: HUCITEC/NUPAUB/CEC/USP, 2005. p.239-254.

VILLEGAS, M. Arquitectura y diseño. Bogotá: Villegas Editora, 2003.

VOSGUERITCHIAN, A. B. A abordagem dos sistemas de avaliação de sustentabilidade da arquitetura nos quesitos ambientais de energia, materiais e água, e suas associações às inovações tecnológicas. Dissertação de Mestrado - Faculdade de Arquitetura e Urbanismo, Universidade de São Paulo. São Paulo, 2006.

VRIES, S. K. Bamboo Construction Technology for Housing in Bangladesh. M. Sc. Thesis in Technological Development Studies - Faculty of Technology Management Eindhoven University of Technology. Eindhoven, 2002.

WEIMER, G. Arquitetura Popular Brasileira. São Paulo: Martins Fontes, 2005.

YAZIGI, W. A técnica de edificar. São Paulo : Editora PINI, 2004.

YIN, Robert. Estudo de caso. Planejamento e métodos. Porto Alegre: Bookman, 2005.

YOSHIKAWA, I. Building Bamboo Fences. Tokyo: Graphic-sha, 1997. 
APÊNDICE - QUESTIONÁRIOS LEVANTAMENTO DE DADOS PRIMÁRIOS
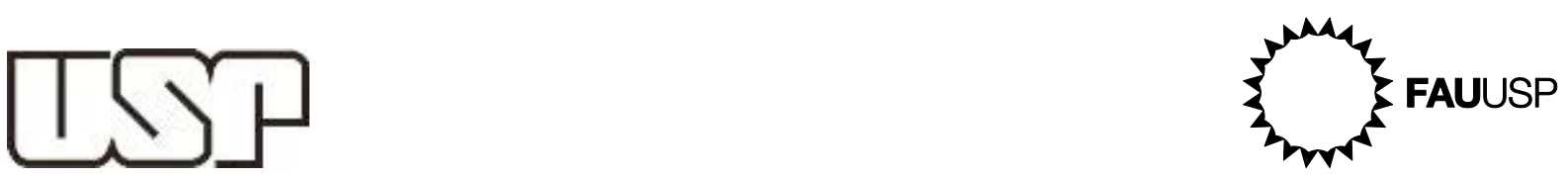

Universidade de São Paulo

Faculdade de Arquitetura e Urbanismo

Curso de Pós-graduação

Questionário de levantamento de dados primários - Pesquisa habitações tradicionais no Vale do Ribeira

Dados gerais (para uso do pesquisador)

Localização

Uso

Arranjo dos espaços (implantação)

Arranjo dos espaços (interior à edificação)

Sistemas construtivos e subsistemas

Patologias de tais sistemas

Infraestrutura existente

Esgoto

Água

Energia

Vias públicas 

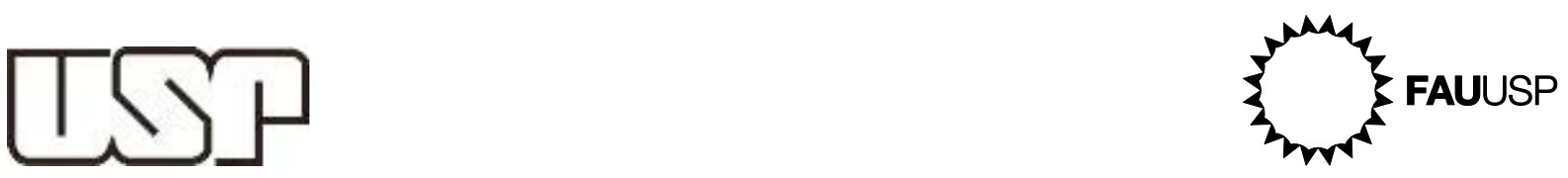

Universidade de São Paulo

Faculdade de Arquitetura e Urbanismo

Curso de Pós-graduação

Questionário de levantamento de dados primários - Pesquisa habitações tradicionais no Vale do Ribeira

Esta pesquisa faz parte da dissertação de mestrado: Sustentabilidade socioambiental: sistemas construtivos em bambu para autoconstrução no Vale do Ribeira, SP e abrange questões tecnológicas, e culturais sobre o espaço construído na região, visando desenvolver um sistema construtivo adaptado às demandas locais. A participação na pesquisa é livre.

$\mathrm{Eu}$,

Declaro estar de acordo em participar como voluntário desta pesquisa, autorizando a divulgação de dados e imagens para fins científicos.

Assinatura

Perfil do(s) habitante(s)

\begin{tabular}{|l|l|l|l|}
\hline NOME & IDADE & OCUPAÇÃO & $\begin{array}{l}\text { GRAU } \\
\text { PARENTESCO }\end{array}$ \\
\hline & & & \\
\hline & & & \\
\hline & & & \\
\hline
\end{tabular}


Como foi executada a casa? Quantas etapas?

Quem executou a casa?

Quais principais inconvenientes na casa?

Quais alterações sugerem? Por quê? 


\section{APÊNDICE - ENTREVISTAS}

As entrevistas desenvolvidas ao longo de 2011 e 2012 consistiram em uma fonte de levantamento de dados primários para a pesquisa sobre o bambu na construção civil, com o intuito de dirimir dúvidas sobre o processo produtivo do material e o processo de concepção de projeto. Para tal objetivo, foram entrevistados a arquiteta brasileira Leiko Motomura, o engenheiro brasileiro Danilo Candia e o arquiteto colombiano Simón Vélez. Os três entrevistados puderam em seu relato trazer diferentes aproximações sobre o status atual da construção civil em bambu e os principais entraves em sua utilização.

Leiko Motomura é graduada pela Faculdade de Arquitetura Mackenzie, possui estágio no Japão e experiência profissional em equipe e como autônoma no Brasil, em projetos corporativos e residenciais. Participou de Congressos na Alemanha, Turquia, Colômbia, Cuba, Costa Rica e Estados Unidos e recebeu o prêmio Planeta Casa de 2005 e a menção Honrosa na 8o Bienal de Arquitetura e Urbanismo. Junto ao seu escritório Amima, é autora do projeto do Centro Cultural Max Feffer em 2008, atualmente a maior obra executada em bambu no Brasil, e objeto específico da entrevista em questão.

Danilo Candia é engenheiro agrônomo, graduado pela Universidade Estadual Paulista, agro-ecologista focado na introdução de agronegócios sustentáveis para o Brasil. Foi diplomado em Bambu Guadua na Universidade Tecnológica de Pereira-Colômbia. É sócio diretor da empresa privada de construção civil Bambu Carbono Zero, e contribuiu com seu conhecimento específico sobre a cadeia produtiva do bambu no Brasil.

Simón Vélez é arquiteto colombiano, egresso da Universidad de los Andes. É considerado o arquiteto com maior reconhecimento internacional na utilização do bambu como principal componente arquitetônico. É responsável pelo projeto das maiores obras de bambu construídas no mundo, entre elas o pavilhão ZERI para a Expo Hannover de 2000 e o Museo Nómada na Cidade do México. Recebeu uma série de prêmios de dimensão internacional, como o Prêmio Principe Claus em 2009, e frequentemente é convidado para ministrar palestras e workshops sobre o uso do bambu na construção ao redor do mundo. 

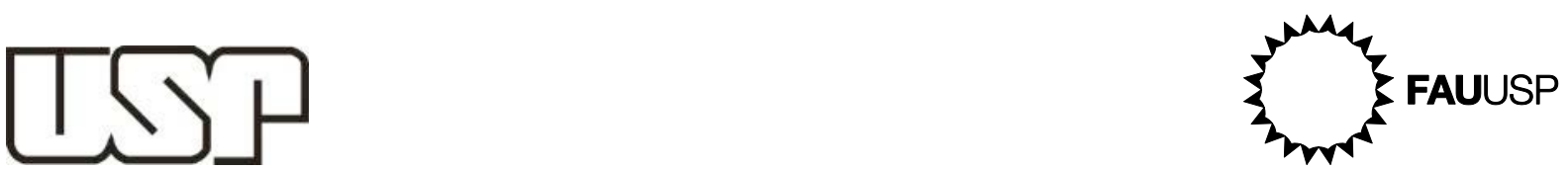

Universidade de São Paulo

Faculdade de Arquitetura e Urbanismo

\section{Curso de Pós-graduação}

Entrevista Arquiteta Leiko Motomura - Levantamento de dados primários - Centro Cultural Max Feffer - Estrutura de bambu: projeto, construção e verificação do sistema estrutural

São Paulo, 25 de Agosto de 2011.

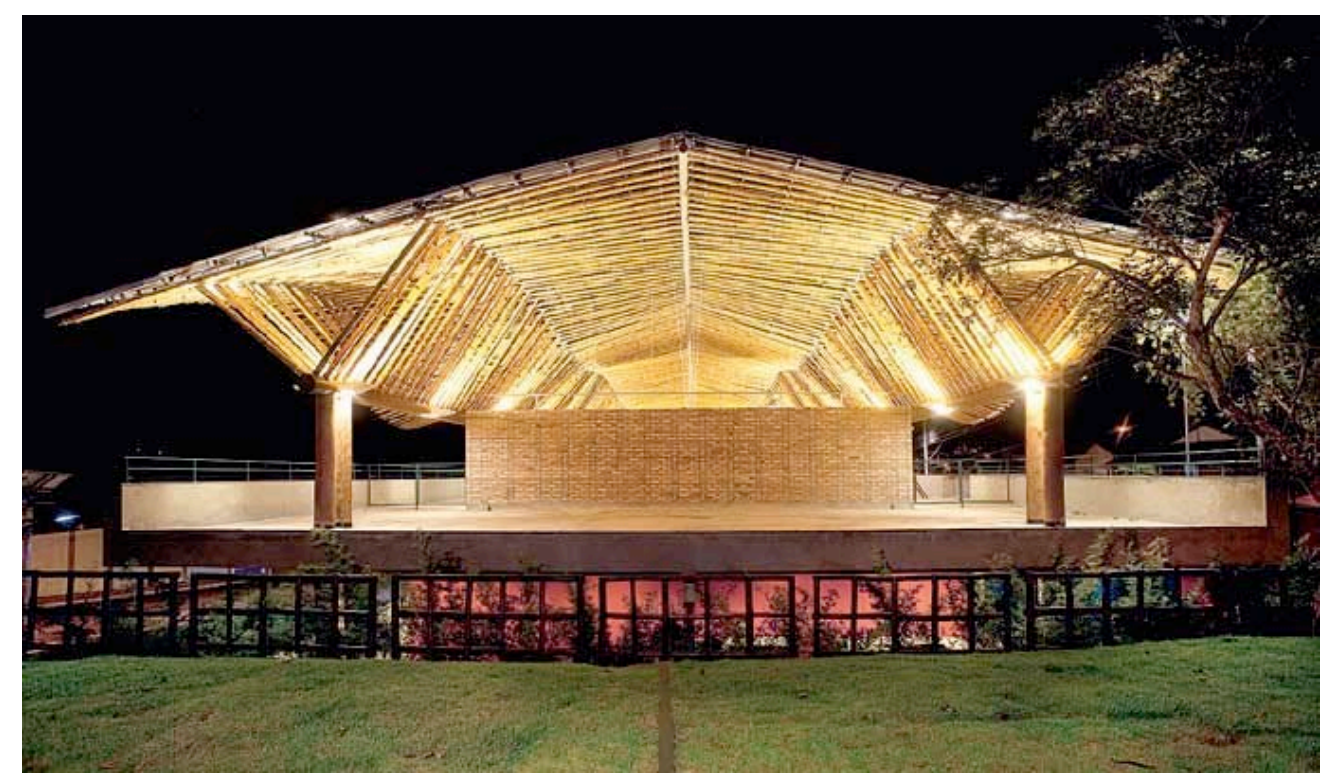

Figura 183 - Centro Cultural Max Feffer. Vista do palco.

Fonte: http://www.amima-arquitetura.com/

\section{INTRODUÇÃO}

Leiko Motomura - Dentro do seu estudo de habitação para autoconstrução, digamos, a estrutura do centro ${ }^{32}$, tem a história do processo todo: do projeto, do cálculo, da

\footnotetext{
${ }^{32}$ Centro Cultural Max Feffer, projeto desenvolvido pela arquiteta Leiko Motomura e objeto de estudo de
} caso. 
construção, mas não é um tipo de solução estrutural apropriada para o caso $^{33}$, é só para a análise do material, certo?

Paula Noia - Exatamente. É para a análise do material e do processo, da metodologia. Estruturei algumas perguntas ao longo da entrevista, que vão explicando a metodologia no caso, mas obviamente não é a mesma solução, aqui temos grandes vãos, etc. De repente a solução não será nem estrutural, talvez seja uma vedação... Então elaborei algumas perguntas, primeiro falando um pouquinho do projeto, depois da construção e depois da verificação.

\section{PROJETO}

\section{O BAMBU COMO MATERIAL:}

$\boldsymbol{P} \mathbf{N}$ - Primeiro eu queria que você falasse um pouco, apesar de saber da relação do projeto com o Instituto Jatobá ${ }^{34}$, gostaria de saber um pouco sobre o material: Por que o bambu? Quais foram as condicionantes que fizeram a escolha do bambu como um dos materiais definidos na elaboração do projeto do centro?

L M - Na verdade, nesse projeto do Centro ele foi um pedido. Não é que eu comecei o projeto e falei: "Vamos usar o bambu pois ele tem a qualidade $x$ e y." Ele já veio no pedido do projeto: "Quero um Centro Cultural usando bambu." Então, não foi uma escolha. E aí entra toda a questão do Instituto tendo uma fazenda cultivando bambu e acreditando nele como material a ser usado na construção civil.

Agora, eu acho que dentro de todo o enfoque da sustentabilidade, ele foi um material adequado. Não sei se eu teria o escolhido se não tivesse vindo com o pedido, porque acho que ele é um material ainda novo, tem muita pesquisa em andamento, muito do que estamos fazendo é experimental e o cliente tem que estar ciente disso. Então, talvez se eu tivesse pego este projeto sem o pedido de fazer a cobertura em bambu, talvez eu não tivesse feito, porque acharia que teria muita pesquisa a ser feita para ter certeza de que vai dar certo, dar garantia. Mas como o cliente pediu, sabia dos riscos, sabe que o material ainda está em pesquisa e bancou tudo isso, aí fui em frente.

P N - Sim, até porque é algo que ele também tem interesse em firmar como material, enquanto produtor...

L M - Com certeza.

\footnotetext{
${ }^{33}$ Caso da pesquisa de mestrado em andamento: Sustentabilidade socioambiental: desenvolvimento de sistemas construtivos em bambu no Vale do Ribeira, SP.

${ }^{34} \mathrm{O}$ Instituto Jatobá, em parceria com a prefeitura de Pardinho, foi o cliente que solicitou o projeto do Centro, e possui a Fazenda dos Bambus, onde vem sendo desenvolvido o cultivo de várias espécies de bambu.
} 


\section{TIPO, PROVENIÊNCIA, TRANSPORTE E TRATAMENTO:}

$P N$ - Sobre as espécies, quais foram as espécies que vocês utilizaram? Foi o projeto que determinou a escolha dessa espécie ou a espécie estava disponível e o projeto foi em função dela? Qual a proveniência e tratamento realizado nesse bambu?

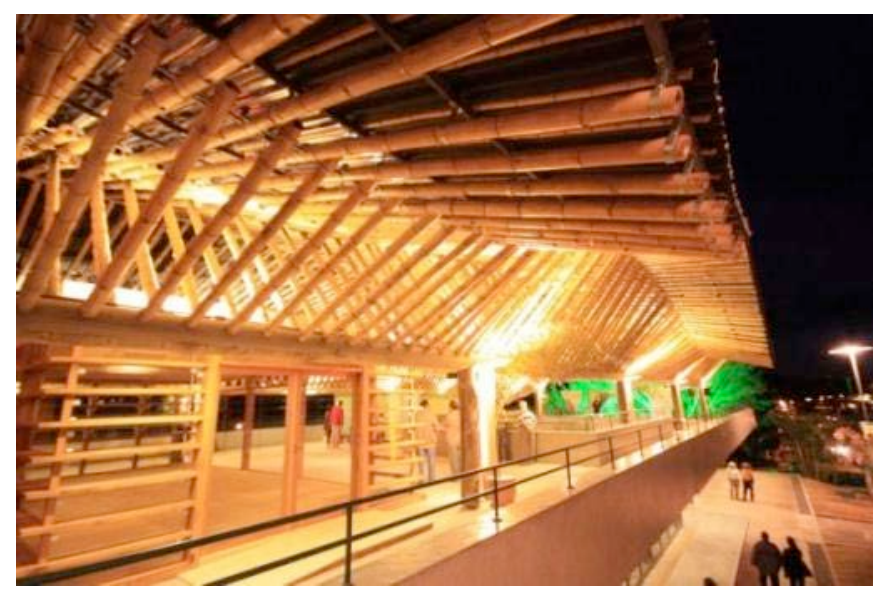

Figura 184 - Vista lateral da cobertura.

Fonte: http://www.amima-arquitetura.com/

LM - Bom, acho que a escolha da espécie teve um olhar técnico porque a espécie de maior disponibilidade aqui em São Paulo não é a que foi usada. Ela foi buscada fora do Brasil, nós fomos pegá-la no Paraguai. Então, houve uma análise da solução estrutural, do vão necessário para o projeto daquele porte, e aí buscamos uma espécie que tivesse um desempenho bom para aquela solução. A espécie que mais temos aqui em São Paulo cultivada é a espécie Mossô ${ }^{35}$ que é essa que você está vendo aqui. Então, externamente ela pode ser semelhante ao que nós usamos lá, é um pouquinho mais fina. Não é uma diferença como entre o Mossô, que chega a uns $8 / 9$ centímetros de diâmetro e o Gigante ${ }^{36}$, que temos muito por aqui também e chega a 15/20 centímetros na base, é uma diferença muito grande entre um e outro. Enquanto que da Guadua ${ }^{37}$ para o Mossô, a dimensão externa não muda tanto, a média de diâmetro que usamos lá é de 10/11 centímetros, enquanto o Mossô chega de $8 / 9$ centímetros.

Mas a diferença fundamental entre elas é a espessura da parede. A diferença de espessura de um Mossô para um Guadua é muito grande. Você tem aí uma atrás de você um exemplo,

\footnotetext{
${ }^{35}$ Phyllostachys pubescens ou P. edulis.

${ }^{36}$ Dendrocalamus giganteus.

${ }^{37}$ Guadua chacoensis
} 
olha a diferença entre o Mossô e a Guadua. Por fora, você vê que quase não tem diferença, mas a espessura do Mossô é quase a metade da do Guadua.

PN - Logo o desempenho estrutural é bem diferente...

LM - Sim. Neste aqui você pode parafusar coisas... Então a escolha da espécie foi pelo desempenho. Daí começamos a procurar dessa espécie Guadua, você tem duas famílias grandes que são mais conhecidas. Existem outras famílias que estão sendo descobertas também. Mas dentro da Guadua você tem a Guadua angustifolia, que você encontra mais na região norte do país, região amazônica, no Equador, Colômbia e essa que nós usamos é a Guadua

chamada

Guadua chacoensis. Essa Guadua já é encontrada mais aqui no sul: Paraguai, Uruguai, Rio Grande do Sul, uma área do pantanal, Campo Grande, etc. Aí a nossa dificuldade foi encontrar o material cultivado, pois ninguém tem cultivo disso, ele existe na mata nativa. Então, conheci um pessoal lá do Rio Grande do Sul, que tem um escritório de arquitetura, dois arquitetos jovens, eu estava aliás conversando com duas pessoas. Um era um agrônomo que tinha o contato de uma fazenda lá no Paraguai, ele estava fazendo uns trabalhos lá com o pessoal, e lá existia essa espécie nativa, na floresta. Aí nós fomos andando, conversando com ele e no meio do caminho ele desistiu, alegando ser uma coisa muito trabalhosa, que não poderia se garantir, pois usamos lá mais de 200 estacas de bambu, é uma quantidade muito grande. Às vezes você não imagina isso, só vendo o caminhão chegando com a carga que você vê o tamanho do negócio. Cortar, tratar e trazer até aqui...é um negócio maluco. Se a gente soubesse o trabalho que iria dar... A gente foi indo aos poucos, mas tivemos muitas dificuldades. Eu fui até a fazenda para dar uma olhada na qualidade deles: é reto, não é reto, é torto... Para você usar 260 colmos, você tem que encomendar quase 400, para poder escolher, cortar, descartar alguns... Então fomos olhar quantos tinha naquela floresta para ver se dava para comprar dali. E aí nós fechamos no final com esses dois arquitetos que começaram trabalhando com esse agrônomo que começou a conversa e eles forneceram. Agora o tratamento feito foi um tratamento de banho.

PN - De imersão?

LM - Sim, de imersão com pentaborato: eles fizeram um buraco no chão, forraram lá e deixaram o material em tratamento.

PN - No local da obra?

LM - No local da floresta, antes do transporte. Então eles trataram tudo lá, fizeram uma tenda, um buraco no chão, forraram e enfiaram lá os bambus, porque os bambus eram grandes. O nosso vão no sentido transversal é de 11 metros, e no outro sentido tem pilar de 9 em 9 metros. 
$\mathbf{P N}-$ E eles foram transportados já com os cortes?

LM - Não, não, isso tudo tem que ser feito na hora, na obra. Para transportar foi aquele caminhão de cavalo mecânico, teve até que desmanchar o portão da fazenda para ele fazer a curva para entrar na fazenda. O volume, você não imagina... Enquanto você não faz uma vez, você não imagina que volume de bambu é esse. E aí ele veio num tamanho maior, foi todo cortado e nós deixamos na fazenda, porque se fosse na obra teria sido um problema. Uma obra deste tamanho necessita de um planejamento do canteiro de obras muito bem feito, o que não foi feito aqui. Isso aqui estava no meio de uma praça, e seria difícil armazenar isso numa época de chuva no início da obra. O armazenar e o trabalhar com peças grandes como essas necessitam de um grande galpão. A sorte é que nós tínhamos um galpão na fazenda onde iria funcionar uma oficina de bambu, então já tínhamos o espaço necessário. Daí armazenamos todo o material com uma capa de plástico, mas toda essa fase paralela à obra deveria ter tido mais cuidado no planejamento. Fomos meio doidos... A oficina para trabalhar com isso, o local para cortes, armazenagem após o corte, eram coisas que não estávamos imaginando. Eram montanhas de bambu.

PN - O maior colmo de bambu utilizado então era de quantos metros?

LM - O vão é de $11 \mathrm{~m}$, mas existe uma emenda bem ao meio. São 4 peças para fazer as duas águas da cobertura. Está vendo aqui uma parte mais densa? Aqui é onde se intercala as peças de bambu, onde faz a emenda. Aqui está chegando também o bambu da mão francesa. O pedaço maior que usamos é de aproximadamente 6 metros, pois aqui temos uma sobreposição bem grande, de aproximadamente $1,5 \mathrm{~m}$. O balanço deve ter uns 3 metros.

\section{SISTEMA ESTRUTURAL:}

PN - Bom, agora falando um pouco sobre esse sistema, já que estamos nisso, você já tinha o material escolhido, e quais foram as condicionantes que fizerem você pensar nesse sistema estrutural, nesse arranjo: mão francesa, entrelaçamento, etc?

LM - Na verdade a gente pensou num sistema relativamente simples, porque isso aqui é um telhado de duas águas. Aí para estruturar esse vão enorme, a gente pensou na mão francesa, com essa estrutura de eucalipto (Figura 185). Aí essa repetição de peças é também um princípio que adotamos sempre que projetamos em bambu. Fazemos uma solução estrutural em que a carga não está concentrada em poucos elementos, a carga é distribuída. E a solução das conexões sempre de uma forma em que você consiga substituir a peça. Ai tem coisas bem interessante, por exemplo, essas barrinhas (Figura 186) aqui ligam sempre três bambus. Esta vendo que tem uma ligeira defasagem aqui? O que acontece, ele liga esses três bambus e nos outros dois próximos tem o furo, que é pra essa barra poder entrar 
pra lá pra soltar o bambu. Então se você observar aqui, por exemplo, essa barrinha está segurando esses três, uma mão francesa e essas duas laterais, mas nesses outros bambus você vai ver que neste alinhamento tem um furo, porque na hora que você desparafusa essa barrinha tem que ter aonde entrar para liberar esse bambu para trocar. Daí você troca e desloca a barrinha lá dentro de novo.

PN - Não fica nenhuma falha, nenhum ponto fragilizado no sistema.

LM - É. Primeiro você consegue tirar a peça sem problemas, porque está com a carga super distribuída, você pode trocar qualquer peça que isso não vai cair. E na hora de bolar o sistema de ligação, tudo isso foi pensado, e aí tem uma contribuição imensa do calculista. Nós já fizemos quatro estruturas de bambu, e vamos aprendendo os problemas que vão surgindo ao longo da manutenção, da vida útil do prédio, e todos os cuidados dessas ligações...

PN - A não-necessidade de escoramento durante a manutenção/substituição de peças é bem interessante no projeto. A distribuição das cargas sem gerar nenhum ponto de instabilidade...

LM - É, bem diluída, não gera nenhum ponto de "stress" na estrutura

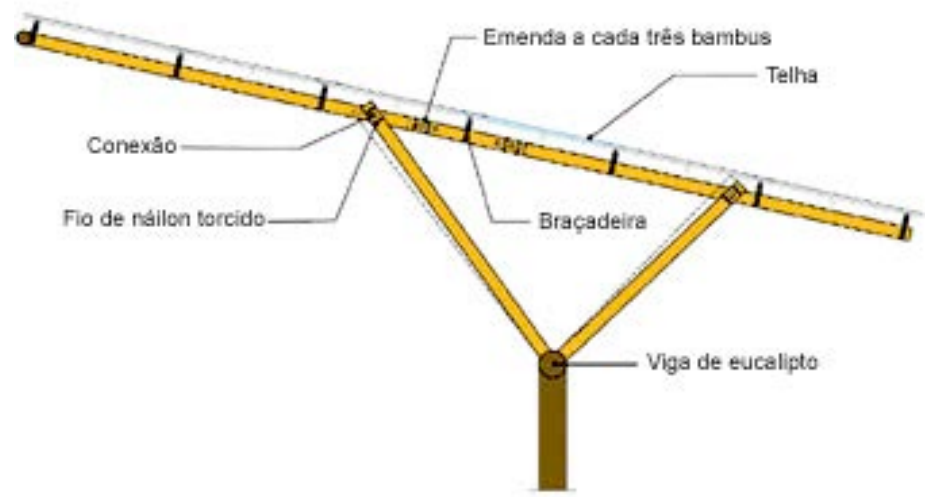

Figura 185 - Croqui esquemático da mão francesa.

Fonte: http://www.amima-arquitetura.com/ 


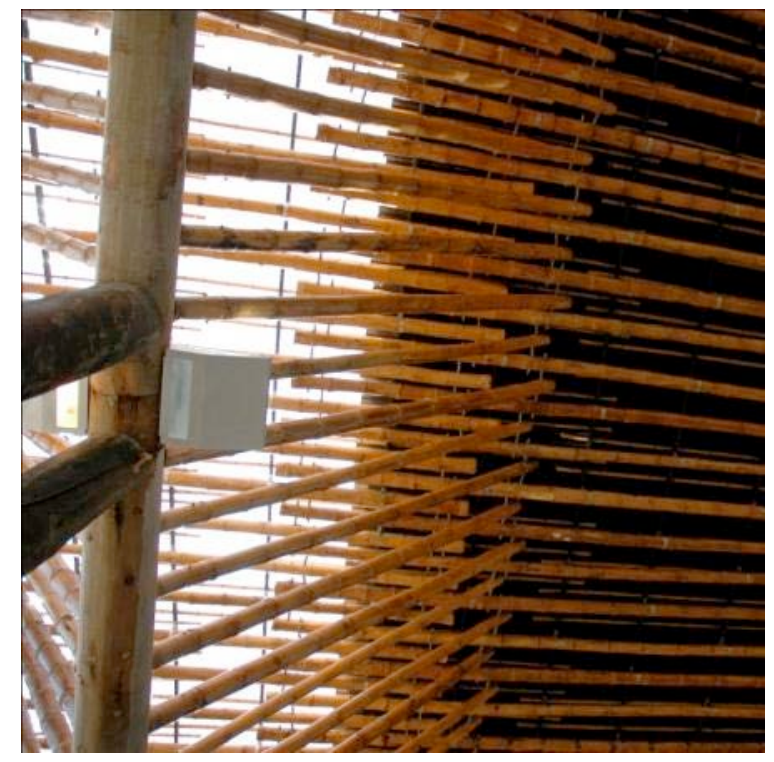

Figura 186 - Barras metálicas interligando os colmos de bambu.

Fonte: http://www.amima-arquitetura.com/

\section{PESQUISA}

$P N-E$ sobre o desenvolvimento do projeto estrutural em bambu, houve alguma equipe que assessorou o processo? Houve pesquisa em paralelo ao projeto, contato com algum pesquisador na área? Soube que houve participação do Beraldo ${ }^{38}$, qual foi a contribuição para o projeto?

LM - Esse bambu, a Guadua chacoensis, era pouco conhecido e testado, diferentemente da Guadua angustifolia. A última, como os colombianos usam muito, já possui vários estudos de resistência e tudo mais. $O$ bambu gigante e o mossô, mais conhecidos, também têm. Mas esse daí não tinha muitos testes. E como a gente estava com prazos curtíssimos entre a montagem e todas essas conferências, o calculista pediu alguns testes para poder calcular tudo isso, aí é que o Beraldo ajudou, fazendo uma parte dos testes na UNICAMP e outra parte foi feita por um conhecido do calculista na Engenharia da USP São Carlos, em um laboratório de madeira muito interessante, bacana. Ele também se dispôs a fazer alguns testes, e aí que conseguimos reunir dados para que o Natan ${ }^{39}$ ter segurança e calcular.

Teve não só a participação do Beraldo, mas não sei se você conhece o Pereira ${ }^{40}$ de Bauru, ele também foi uma peça importante. No meio do caminho, esse material começou a ser atacado por bichos, mesmo tratado. Todo mundo ficou apavorado, pois era um inseto que

\footnotetext{
${ }^{38}$ Antonio Ludovico Beraldo, engenheiro agrícola e professor da UNICAMP, SP.

${ }^{39}$ Natan J . Levental, engenheiro calculista do projeto.

${ }^{40}$ Marco Antônio dos Reis Pereira, engenheiro agrícola e professor da UNESP, Bauru.
} 
não estavam acostumados a ver por aqui, não era aquela broquinha pequena, era um inseto maior, chamado Dinoderus minutus ${ }^{41}$. Na hora que começou aparecer esse bicho, com a obra andando, um monte de material, todo mundo ficou apavorado. Aí nós fomos conversar com o Pereira, indicado pelo Beraldo. Fui até Bauru, ele foi comigo até a fazenda ver o estado do bambu, se estava devidamente seco, tratado. Aí ele falou assim: "Alguns deles estão verdes ainda, não foram colhidos com a idade certa". Tivemos que descartar um monte, porque os verdes, se não secos devidamente, começam a rachar. Dentro de toda aquela quantidade de bambu, tinham muitos rachando. Quanto aos bichos, entramos em contato com um Uruguaio que se chama Guillermo... Não lembro os sobrenome dele, ele mora lá no Uruguai e constrói muito em bambu, e o bambu da região dele é esse. Pagamos uma passagem para ele vir até aqui olhar. Ele foi de muita ajuda, pois ele conhecia o bambu e disse: "Olha, o negócio é o seguinte, o que estragou é porque não estava bom, estava verde, não foi tratado adequadamente. Terão que descartar. O que sobrou e não está sendo atacado, você utilizará, é como uma seleção natural."

Daí nós tivemos um problema muito grave porque descobrimos que haviam peças sem tratamento no meio de todo o resto. E não sabíamos qual estava tratado ou não. Então na obra, existiam bambus que não foram tratados. Depois de tudo pronto começamos a ver ataques em algumas peças. Não foram muitas, mas tinham algumas.

Então sofremos muito por causa dessas coisas, a gente teve que resolver diversos problemas que não era pra ter acontecido e precisaram ser resolvidos. A gente passou apertado em tudo isso.

PN-Esses bambus sem tratamento não tinham realmente passado por nenhum processo?

LM - Não... Então atualmente está em observação. Colocamos uma cláusula no contrato de que todo ano deverá ser feito o fumigamento preventivo. Não dá para ficar sossegado, então é um tratamento de prevenção anual, se tiver algum tipo de ataque...

$P N-C o n t r a$ fungos e insetos também?

LM - Sim, infelizmente... Já que não temos $100 \%$ de certeza do tratamento. Quanto à manutenção, agora que a obra fará 3 anos, irei conferir todos os parafusos, etc, o que também acontece em uma estrutura metálica. Ver se está tudo ok, apertar tudo, ver se há alguma coisa frouxa...

Nós usamos a própria estrutura de amarração das longarinas para fazer uns anéis para evitar as rachaduras. Uma coisa que todos falam que você pode ter certeza sobre o bambu é de que ele vai rachar. Então você sempre precisa ter uma solução para segurar, então a própria

41 Caruncho, gorgulho, ou carcoma, insetos xilófagos que atacam bambu, madeira, e cereais. 
estrutura de amarração da longarina na estrutura da cobertura já é uma abraçadeira. Então, ele já amarra em vários locais. Além disso, tem uma fita que amarra o bambu especificada pelo arquiteto Uruguaio. Foram feitas umas 6 voltas e amarradas. Nós compramos as fitas, amarramos um monte, mas os bichinhos começaram a cortar os cordões, e estes começaram a cair no chão. Aí fomos ver que o tipo de cordão era um pouco diferente do que ele tinha falado. Ele tinha falado um nome, mas que havia um detalhezinho que fazia ser de um tipo diferente. Tivemos que comprar e amarrar tudo de novo.

$P N-$ Era feito em algum componente vegetal esse cordão?

LM - Não tinha componente vegetal, mas era alguma diferença no trançado, que fazia com que os bichos atacassem. Aí nós fizemos o primeiro fumigamento. Cairam todos os bichos e depois disso não ouvi falar nenhuma vez. Temos que fazer esse levantamento, ver se está amarrado, se precisa apertar...

$P N-E$ essa amarração é feita somente nos pontos de junção ou em outros pontos do bambu?

LM - Não, é basicamente nos lugares onde você tem um metal, onde pode ter um esforço maior. Para segurar, caso venha a rachar. Do lado de cada furo você tem dois amarrados.

\section{VERIFICAÇÃO}

\section{DESEMPENHO}

PN - Como está sendo o desempenho do pós-uso do ponto de vista estrutural? Algum problema de manutenção de peças ou sistemas? Tiveram muitas substituições?

LM - Não, não. Nós só tivemos aquela troca antes do prédio ficar pronto. Na hora que a gente colocou, que já vimos que tinham furinhos, nós já trocamos. Depois disso não foi feito nenhum tipo de substituição. É preciso que vá alguém verificar tudo como está, apesar de não termos nenhum relato de deterioração. Aparentemente, na parte estrutural ainda não tivemos nenhum problema até agora.

$P N-E$, acho que a manutenção preventiva já vai alertar se existir algum problema próximo... $L M-E$. 


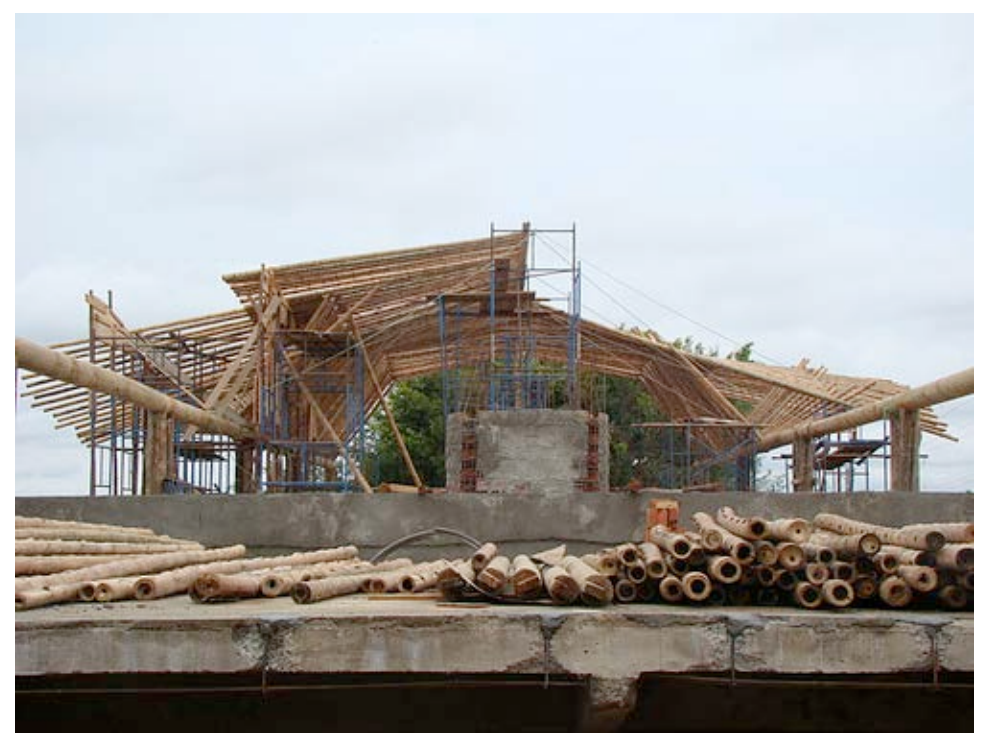

Figura 187 - Montagem da cobertura - gabaritos.

Fonte: http://www.amima-arquitetura.com/

\section{CONSTRUÇÃO}

\section{RECURSOS}

PN - Bom, falando um pouco sobre a execução, como foram os recursos humanos $e$ materiais necessários para a execução dessa cobertura?

$L M$ - Se é mão-de-obra preparada ou não?

PN-Exatamente, foi uma mão-de-obra especializada ou vocês a capacitaram?

LM - Não, não foi uma mão-de-obra específica porque não existe quase isso. Tem um grupo muito pequeno lá da Celina ${ }^{42}$, que sabe fazer uns cortes, uns encaixes aquele encontros que os colombianos fazem, tem um outro grupinho lá perto de Campinas, do Edoardo, mas é pouca gente. Agora, para uma obra desse tamanho, na verdade, eu fui procurar um marceneiro bom. Um marceneiro que soubesse fazer estruturas de madeira bem feitas. Aí, eles nunca tinham mexido em bambu. Acho que para qualquer profissão, o cara não precisa ter experiência, o cara precisa ter cabeça, pois quem tem cabeça aprende qualquer coisa. $E$ foi o que aconteceu, eles nunca tinham mexido no bambu, a gente tinha alguma experiência nos cortes, como tinha que fazer, foi explicar pra eles e pronto. Para fazer algumas coisas a gente inventou algumas maquininhas: pega um motor, enfia uma lixa, faz um negócio... E aí você consegue se virar, você conta isso pra eles e eles saem fazendo. Então, isso tudo aqui, o primeiro sistema que foi pensado para montar isso, que veio lá do calculista, era uma folha

42 Celina Llerena, arquiteta e diretora da EBIOBAMBU. 
deste tamanho com um monte de númerozinhos, porque cada encontro, cada mão francesa tem um comprimento diferente, você vê aqui que é uma complicação para montar isso. $\mathrm{E}$ disso saiu aquela tabela que matematicamente estava corretíssima, com comprimento de cada braço, o ângulo, uma complicação! E aí ele começou a montar. Ele trabalhou um dia, aí ele veio conversar comigo e disse: "Olha, não vai dar para fazer desse jeito. Muito complicado" Daí ele já veio com uma ideia, isso que é o legal do cara que tem prática e é inteligente, ele falou assim: "Você não consegue imprimir para mim uma onda em tamanho natural, em dois pontos?" Porque daí toda inclinação já sai automaticamente, é só apoiar a peça em cima desses gabaritos. Eu imprimi as duas ondas, ele recortou em um madeirite, montou no local certo, e aí pronto, é só apoiar as peças, e daí o negócio foi rapidíssimo. Transpondo o gabarito você tem o telhado inteiro. E eles foram espetaculares. Eu tiro o chapéu para esse pessoal.

PN - Aproximadamente quantas pessoas, Leiko?

$L M-$ Quantas pessoas? Devia ter assim uns cinco/seis profissionais.

$P N-E$ quanto tempo mais ou menos eles levaram para concluir a estrutura?

LM - Quanto tempo? Olha eles fizeram essa estrutura também (estrutura de pilares em eucalipto). Eles desconificaram todo o eucalipto, ele está com o mesmo diâmetro da base até o topo, que já é uma coisa que não é todo mundo que faz. Agora para montar tudo isso...vocês sabe que eu nunca experimentei contar, mas acho que a parte da cobertura deve ter começado em Junho o pré-preparo disso para depois montar. Acho que a obra começou mais ou menos de abril pra maio, até eles chegarem à condição que eles pudessem montar esse negócio, acho que foi em Junho.

PN - Mas foi em uma etapa só?

$L M$ - Foi. Fizeram tudo isso aqui, depois a cobertura, teve que esperar um pouquinho para serem colocadas todas as longarinas. Esse também foi um trabalho que eu tiro o chapéu para eles. Pois em cada corte, a curva é diferente. Dessa mais acentuada até virar zero. Então cada linha de longarina tinha uma inclinação, uma ondulação totalmente diferente uma da outra. Eles montaram, e na hora que eles começaram a avançar para o lado eles começaram já a montar o telhado.

$P N-$ Realmente uma equipe muito eficiente.

LM - Muito boa. E assim a gente chegou lá.

PN-Parabéns pela obra, ela é muito bonita, e todos a admiram no nosso meio. 
$L M-E$, mas foi muita coragem de todo mundo, sabe, do cliente, da gente, dos montadores, porque era uma coisa nova, uma coisa nova para todo mundo. Tiveram muitas noites que eu não dormia porque eu sabia que tinha problemas para resolver. Você tem que vestir a camisa, senão não sai. 

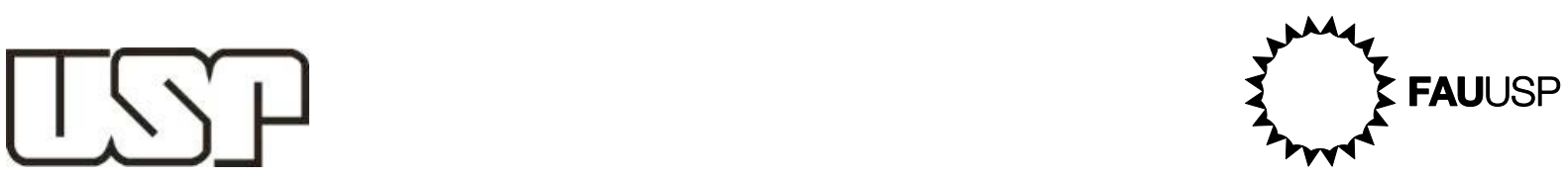

Universidade de São Paulo

Faculdade de Arquitetura e Urbanismo

Curso de Pós-graduação

Entrevista Engenheiro Danilo Candia, diretor da Empresa Bambu Carbono Zero Levantamento de dados primários - Cadeia produtiva do bambu no Brasil.

São Paulo, 16 de Setembro de 2011.

\section{PRODUÇÃO AGRÍCOLA NO VALE DO RIBEIRA}

Paula Noia - O primeiro e-mail que Ihe enviei perguntando onde haviam produtores de bambu no Vale do Ribeira soou estranho, uma vez que você é comprador do material desses pequenos produtores ${ }^{43}$...

Danilo Candia - Na verdade eu brinco, mas falo mesmo: eu falo tudo sobre o bambu, menos onde está o bambu... Tudo o que você precisar, a tecnologia que estou fazendo, como eu a faço, etc...

P.N. - Na verdade só precisava saber o quão factível e viável é a produção agrícola de Bambu nessa área, que as pessoas podem dar continuidade a uma cultura existente... Para a comprovação e elaboração do projeto no contexto desta pesquisa. Já que você mesmo falou que como engenheiro agrônomo pode garantir que é possível a cultura desse material no local...

D.C. - Sim, ele está lá. A foto que você me mandou é do Dendrocalamus giganteus ${ }^{44}$ dá pra construir, é o melhor que tem no mercado hoje para construir. Lá tem, e não é pouco não... Uma das maiores plantações de bambu que eu conheço na minha vida tá no Vale do Ribeira. Lá o cara tem Phyllostachys, tem Mossô, tem Medake e tem Gigante, bastante. 0 proprietário está destruindo a plantação de Gigante dele. Ele encontrou um cara do sul que

\footnotetext{
${ }^{43}$ Danilo Candia, engenheiro agrônomo e empresário diretor da empresa Bambu Carbono Zero atua no tratamento, beneficiamento e comercialização de bambus e seus produtos além de comercialização de mudas e consultoria em agronegócio.

${ }^{44}$ Foto enviada para Danilo para análise de espécie comumente encontrada pela pesquisadora no Vale do Ribeira.
} 
está comprando o Gigante para fazer os laminados da Oré Brasil ${ }^{45}$, umas cadeiras com design, e é um cara agressivo, que tem um projeto legal. Ele está plantando bastante Mossô no sul, mas enquanto não tem ainda o resultado da plantação, achou esse japonês dono da plantação e está comprando todo bambu dele. E o cara está serrando de qualquer jeito, eu fui lá conversar com o cara e não teve conversa. Se eu pudesse comprar dele agora eu compraria, mas eu tenho bambu mais perto, até ir buscar lá... Eu deixo o cara da Oré comprar. E ele tem outros bambus lá que um dia eu posso fazer alguma coisa talvez, que são uns bambus de diâmetros menores, ele é um cara grande e eu não gostaria de falar onde está. Lá no Vale do Ribeira está muito espalhado, onde teve colonização japonesa tem. As áreas onde se encontra mais bambu é Juquiá, Sete Barras, a região quando você desce a serra, bem no pé da Serra, próxima à Rodovia, principalmente do lado direito ${ }^{46}$ da rodovia. Tem três caras que eu conheci no Vale do Ribeira e agora tem esse novo que é em Sete Barras/ Eldorado, na zona de transição do Parque. Enfim, no Vale do Ribeira tem, e mais do que isso, é uma região muito boa para o cultivo do bambu. O clima da região, dentro do estado de São Paulo só perde para a região de Ubatuba. A região litorânea, de Peruíbe a Ubatuba, que é uma região muito ruim pra produzir por causa de mão de obra, pois não tem essa cultura de produção rural; no entanto possui o clima ideal. Então o clima ideal está onde ninguém produz. O projeto de pupunha eu comecei lá, mas onde deu certo o desenvolvimento foi no Vale do Ribeira. O Vale do Ribeira produz menos rápido do que Parati, pois está em uma região não tão úmida. A Serra do mar, responsável pela chuva, faz de Iguape não tão úmido, pois já é uma planície. Iguape e Cananéia já não chove tanto quanto de Peruíbe pra cima: Itanhaém, Guarujá, Bertioga, São Sebastião, Ilha Bela, Ubatuba, até Parati, Itaguaí, o clima é muito melhor do que no Vale do Ribeira, mas o Vale vem logo em segundo lugar. Nenhuma outra região do estado tem o mesmo clima, o mesmo nível de pluviometria, de umidade que tem o Vale. Então é o melhor lugar: as terras são mais baratas, as pessoas estão precisando de alternativas econômicas, as prefeituras estão sedentas por novos negócios, que se desenvolvam cadeias produtivas, a gente tem incentivo lá para isso, tem gente lá querendo mexer com isso, tem empresários com dinheiro para fazer isso, eu já tive andando lá com empresários procurando terras, então é uma região que, se eu tivesse capital para investir em bambu eu iria para lá. É a região do bambu no estado de São Paulo.

Nós fizemos um projeto de produção de madeira com bambu que não está mais viável, pois a China está entrando no mercado de pisos aqui em São Paulo direto. Antes os brasileiros compravam na China e revendiam aqui, estava viável mexer com piso, porque os pisos estavam muito caros e a gente tinha um target para trabalhar. Agora as empresas chinesas

\footnotetext{
${ }^{45}$ Empresa catarinense fabricante de mobiliário de materiais ditos sustentáveis como pinus e bambu. http://www.orebrasil.com.br/

${ }^{46}$ Lado direito da Rodovia Régis Bitencourt no sentido São Paulo - Curitiba.
} 
entraram no Brasil direto, hoje a gente já está representando porque não tem como fugir disso. Então pisos, eu estou importando da China direto e revendendo aqui.

\section{P.N. - Você diz pisos laminados?}

D.C. - Não, laminado já era, não concorre com nenhuma madeira de lei. Não sei se você sabe, mas a casca do bambu é onde você tem a densidade maior de fibras, e é onde está a força, o "aço" do bambu é a casca. A parte de dentro é "pinus". Você tem um diferencial de densidade muito alto entre a parte interior e exterior. $E$ essa parte externa garante toda flexibilidade do bambu, a tração, é perdida quando você pega uma seção do bambu na produção de laminados, tecnologia criada de 1945 para cá pelos chineses. Agora os chineses inventaram a chamada madeira de alta densidade: ele pega a régua, passa numa máquina que dá só uma riscada na casca e é esmagado como se fosse um bagaço de caldo-de-cana entre dois tambores. O feixe daquilo é entregue pelos campesinos pra indústria, a indústria toma aquilo como matéria prima, é usada uma cola fenólica livre de formaldeído, que é proibido hoje, e aí essa cola dá uma consolidada durante algumas horas, depois ela entra em uma grande prensa que esmaga tudo com uma pressão tão grande que é capaz de fazer essa alta densidade. Isso é igual ao Ipê. A cola é a mesma cola da fórmica, que é absolutamente impermeável. Então você pega as fibras do bambu, com alta resistência à tração, prensa com essa cola que fica extremamente impermeável e em altíssima densidade devido à capacidade da prensa. Essa madeira concorre com Ipê, com Mogno, com tudo.

\section{P.N. - E aqui no Brasil não há nenhuma indústria similar?}

D.C. - Aqui não tem indústria nenhuma. Aqui não existe, a maior indústria que existe de bambu no Brasil é de papel, que é a João Santos no Nordeste, e agora tem um pessoal entrando forte para fazer biomassa para queima, para cerâmica e siderurgia. Fiquei sabendo hoje que vão entrar 2000 hectares no Mato Grosso para fazer siderurgia do grupo Queiroz Galvão, então isso vai começar a ser utilizado em larga escala, mas indústria de madeira de bambu, no Brasil não existe. Tem só a Oré, que faz alguns "laminadinhos" lá. Acaba ficando um material muito mole, que no caso do piso marca muito fácil.

Hoje um piso maciço de bambu tá em torno de 4800 dólares $/ \mathrm{m}^{3}$ que vai hoje significar $130 / 140$ dólares o $\mathrm{m}^{2}$. Essa é a madeira mais cara que existe no Brasil, o piso. Depois vêm as outras aplicações. Madeira para viga, para telhado, pra caibramento, essas coisas, chega a 2500 dólares $0 \mathrm{~m}^{3}$. Então isso não permite que a gente faça uma indústria de madeira porque a madeira ainda é muito barata, eu vou fazer a madeira a 2700 dólares pra você pegar na Amazônia por 2500 e a cultura já é essa, então a gente precisa de mais alguns anos para que haja uma restrição maior de madeira, para que a madeira fique mais cara, e está ficando: fizemos uma pesquisa com uma construtora e constatamos que nos últimos 3 anos subiu $40 \%$ a madeira. Se continuar nessa curva, e a tendência já vem de dez anos, ou seja, é 
certo que vai continuar ou aumentar, em alguns anos a gente vai ter o preço da madeira já compatível com o preço da madeira de alta densidade do bambu. Quando isso acontecer a gente pode começar uma indústria de madeira aqui no Brasil, porque daí, a China não faz esse tipo de madeira porque tem um valor agregado muito baixo, então a gente vai ter condições de fazer.

\section{P.N. - Como chama esse piso de bambu chinês de alta densidade?}

D.C. - Chama-se strand woven. É uma madeira prensada, depois eu te mostro aqui. Mas laminado de bambu é coisa do passado. A tecnologia da China data de cinco anos e meio pra cá. Nós já fomos à China, sabemos tudo que eles desenvolvem lá, temos engenheiros para implantar a parte chinesa da indústria, de acabamento final, de vernizes, de secagem, de prensa, a gente tem tudo aqui no Brasil melhor que na China, porque a gente tem uma cultura de madeira muito estabelecida. Então o que a gente não tem é a parte de bambu, que é a parte que corta, que racha, que esmaga, até chegar na prensa. Então uma parte da indústria seria chinesa, importada da China e uma parte seria brasileira. A gente já tem tudo isso determinado, os custos, valores, business plan montado e tudo, mas está engavetado, não é a hora, não vamos fazer nada agora. Por enquanto vamos tocando essa Carbono Zero, fazendo pequenas coisas de bambu, um negócio que vai crescendo devagarinho, viabilizando o agronegócio de bambu de médio e pequeno porte pro Brasil inteiro que é o que a gente quer fazer. Tem o bambulhão que é o vergalhão de bambu, tem as casa préfabricadas, toda a parte de revestimento, de estruturas ${ }^{47} \ldots$

P.N. - Cada vez mais agregando valor às peças pelo processo da manufatura...

D.C. - Sim, a nossa fábrica até hoje tem a razão social artesanato. É um produto artesanal. Ele entra na fábrica, é colhido manualmente, colocado em caminhão, chega até Cunha - SP, descarregado na mão, corta um por um na mão, faz régua por régua, limpa régua por régua, cozinha régua por régua, é uma coisa muito artesanal ainda. Mas a gente consegue agregar um valor fazendo coisas muito simples como essa régua de bambu ${ }^{48}$. Por exemplo, meu sócio esteve na Holanda, depois que saiu da China, e ficou impressionado com o que viu lá. A Holanda é um país de grande tradição em transação de negócios, eles são traders por excelência. E por exemplo, aquele aeroporto de Barajas ${ }^{49}$ que fizeram lindo, é chinês, mas foi holandês que pôs lá, que garantiu... Porque a China tem ainda um problema de qualidade... O que eles fizeram é, colocaram doze caras de qualidade na China, eles ficam dentro das indústrias que eles selecionaram, que têm capacidade de produção, qualidade, cuida dos empregados, têm todas as ISOs que precisam. Eles fizeram um catálogo holandês,

\footnotetext{
${ }^{47}$ Produtos da empresa Bambu Carbono Zero

${ }^{48}$ Réguas de bambu cortados em meia-cana que formam o forro da varanda do escritório da Carbono Zero.

${ }^{49}$ Aeroporto Internacional de Madrid Barajas (MAD), projetado por Richard Rogers Partnership.
} 
bacana, com todos os números, índices que precisam, densidade, aplicações, milhões de fotografias e desenhos técnicos, um primor. Eles vendem produto chinês. Nós estivemos lá para tentar fazer um link entre a Holanda e a nossa fábrica de madeiras que queríamos começar aqui, ou uma das ideias era começar vendendo produto da China aqui, quando ainda estava no começo essa história de pisos aqui no Brasil a gente pensou em trazer da China. Mas só que para trazer da China porcaria, e queimar o filme, a gente achou melhor pagar um pouco mais caro e trazer da Holanda, que tem todo aquele nome. Saía $27 \%$ a mais, mas valia a pena pela qualidade do produto. Nós fomos lá conversar com ele, e nos apresentar, eles entraram no site, para conhecer a Carbono Zero e eles abriram o site e viram o preço dos itens, que na época tínhamos disponível no site, na época 120 reais $/ \mathrm{m}^{2} \mathrm{da}$ régua, que na época dava 80 dólares. E eles perguntavam: "Como você consegue fazer isso?", "Mas vocês vendem bastante?" "Por 80 dólares/m²?" Ficaram impressionados, pois isso não era fazer nada no bambu, perto do processo da madeira que eu te falei.

Enfim, no final eles ficaram impressionados com isso e pediram na Colômbia, através de uns braços alemães importantes, uma referência da produção de bambu da Carbono Zero no Brasil, saber se conheciam, se confiavam e eles responderam "Pô, lógico, o Danilo, ele é muito bom!". Falaram um monte...

\section{P.N. - Sim, você esteve lá na Colômbia, não é?}

D.C. - Sim, eu estive lá, interagi com muitas pessoas, e realmente, conheci os alemães, mostrei o meu trabalho, fiz um curso que me destaquei, pois já trabalhava com o negócio há 15 anos, você sempre tem algo a falar para a Universidade... Então esse cara que falou, possivelmente o Jorg $\operatorname{Stamn}^{50}$, com quem tive uma proximidade, deve ter dado um sinal positivo para os holandeses.

P.N. - Na sua opinião, há espaço para crescimento da demanda do material em nosso país ou ainda é um processo muito inicial?

D.C. - Olha, acho que é um processo gradativo. Por exemplo, estou fazendo alguma coisa de obra estrutural, claro não são 300 obras, mas elas vão aparecendo e estamos sobrevivendo disso. Com esse processo, várias pessoas vão vindo atrás. Os bio-construtores, os novos arquitetos, os recém-formados, essa nova geração que tem uma cabeça mais sustentável, porque os velhos arquitetos a gente não vai conseguir fazer pensar em bambu. Mas a sua geração já sai pensando em bambu e vão ser nossos clientes, vão ajudar a desenvolver, vão ser nossos concorrentes, e é aí que está a perspectiva do bambu no Brasil. Eu vejo com muito bons olhos isso. A gente tem o braço florestal da Carbono Zero já bem mais forte hoje, e a gente já está com um bom viveiro de muda e gente tem feito algumas negociações de

\footnotetext{
50 Jorg Stamm é carpinteiro de formação e nasceu em Drohlshagen, na Alemanha. Atualmente vive na Colômbia e trabalha com o bambu como matéria-prima em uma série de construções.
} 
plantio, já tem bastante coisa surgindo. O maior viveiro de Guadua do Brasil é meu e estamos já negociando alguns plantios, que vão começar agora no final de setembro para construção civil, para madeira e inevitavelmente vai criar esse mercado, e a maior parte dele vai ser no Vale do Ribeira.

P.N. - E a relação entre as espécies Guadua, Mossô e Gigante: você considera o Guadua sem dúvida a melhor espécie para a construção civil?

D.C. - Sem dúvida. Bom, o Guadua é um bambu americano, não existe em outros locais, o que é um orgulho para a gente. Temos no Norte um que não é o Angustifolia ${ }^{51}$, mas é um guadua muito bom. Temos também na bacia do Paraguai, várias espécies que não perdem nada em qualidade e são espécies brasileiras, com grande aproveitamento do clima natural. A pupunha, por exemplo, é um produto imbatível em termos de rentabilidade porque é da Amazônia, cresce em clima altamente úmido e altamente quente, então é uma planta com alta produtividade. A mesma coisa com o Guadua, que é um bambu de trópico. O Mossô, o gigante, vieram do Oriente e não são originalmente espécies tropicais. O Mossô cresce a

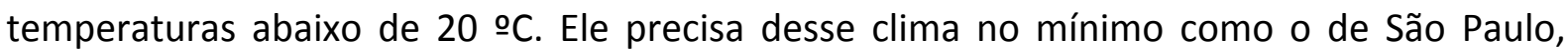
região úmida, mas que é fria. Então, esses bambus são ótimos bambus para trabalhar, mas a produtividade por hectare de massa é menor do que a do Guadua.

Depois o Guadua é um bambu que tem maior espessura de parede em relação ao diâmetro. O Guadua raramente chega a obter o diâmetro do gigante, de 16 a $18 \mathrm{~cm}$. Mas se você pegar um Guadua, um Gigante e um Mossô de $15 \mathrm{~cm}$, e esse é o máximo que o Mossô chega, você vai ter a maior espessura sendo a do Guadua. Além disso você tem no Guadua, a distância entre nós mais curta, o que garante maior resistência mecânica ao colmo, tendo diafragmas a cada $15 / 20 \mathrm{~cm}$, já o gigante a cada $50 \mathrm{~cm}$. A espécie também apresenta um índice de sílica muito maior entre as fibras, que significa ainda mais resistência. Possui também o menor índice de conicidade e retidão, garantindo peças mais retas. De cada 1000 bambus Guadua você vai ter 700 bambus retos. Já do gigante você vai ter 300, e num Mossô, 450. Para construção civil, é mais desejável o bambu reto, então o Guadua é mais indicado.

É um bambu com uma facilidade de colheita, pois ao contrário do gigante, neste você consegue entrar na plantação, pois é uma mistura de alastrante com entouceirante. Ele não espalha, não ganha terreno, mas quando você olha para ele na plantação ele se comporta como bosque. Ele não anda tanto quanto o Mossô, que chega a andar até $15 \mathrm{~m}$ de um ano

\footnotetext{
${ }^{51}$ Guadua angustifolia, espécie comumente empregada para a construção civil na Colômbia.
} 
para outro, o Guadua anda 2,5 m. Pra finalizar, ele é o único bambu que floresce de $7 \mathrm{em} 7$ anos mas não perde o bambuzal, então você não tem o prejuízo ${ }^{52}$.

Tem também o fato dele ser nativo e exótico ao mesmo tempo. Ele pode ser considerado as duas coisas. Por exemplo, na Mata Atlântica ele não existe, mas ele é brasileiro. Então pela legislação ele pode ser cultivado. Mas ao mesmo tempo, há algumas restrições de cultivo, por exemplo, a Juçara: para ser cultivada exige um plano de manejo, uma autorização do Ibama, etc. Nesse caso podemos considerá-la uma planta colombiana, por exemplo. Em certos aspectos, quando eu precisar dele para fazer mata nativa, recompor uma mata ciliar, por exemplo, eu posso falar que ele é brasileiro. Ele tem essa vantagem.

Então para mim o Guadua angustifolia é "o bambu", pois além de tudo isso que eu falei, ele tem mais de 20 anos de estudo nas Universidades da Colômbia.

P.N. - E qual o critério quanto às espécies nativas/exóticas? Por exemplo o Mossô não é nativo do Brasil, significa que pode-se cortar a vontade?

D.C. - Sim, você pode cortar quanto quiser, só não nas áreas de proteção ambiental, que são beira de rio, etc.

P.N. - Há uma relação entre bambu e eucalipto se pensados como monocultura? Há, também no caso do bambu, os mesmos níveis de empobrecimento do solo?

D.C. - Bom, na verdade vou ter que falar bastante sobre isso, pois tem alguns equívocos aí. O eucalipto é um boi de piranha, talvez daqui a 20 anos o bambu esteja no banco dos réus como o eucalipto está hoje. Na verdade o problema é a monocultura, não o eucalipto. Ter 100 milhões de hectares de plantação não faz bem seja ela qual for. Outro equívoco é falar que o eucalipto estraga o solo. Qualquer coisa estraga o solo, o solo é um reservatório, e muito sujeito às intempéries, já que a ação da chuva nos países tropicais degrada muito o solo. Se você só tirar do solo e não adubar não vai conseguir bons resultados. 0 eucalipto na verdade é uma cultura que exige muito pouco, em geral no primeiro ano você faz uma adubação e pronto, e o resto é tudo o que ele tirou do solo. Aí, lógico no corte, depois de 7 anos de extração de nutrientes do solo, o certo para um agricultor consciente, seria repor tudo aquilo. O problema é que não se faz isso, investe-se na plantação, aduba-se e não se faz mais nada, investe-se 2.800 reais por hectare e nunca mais faz nada e no sétimo ano você vai lá e ganha dinheiro pra caramba. É uma visão extrativista, capitalista e nociva, de monocultura. A cana está um pouco acima disso, pois é uma cultura anual, de 2 a 3 cortes e as usinas tratam do solo muito bem. Apesar de ser uma monocultura com muitos

\footnotetext{
${ }^{52}$ Algumas espécies de bambu ao florescerem comprometem toda a plantação, tendo que se esperar que atinjam novamente a fase adulta.
} 
problemas, o solo da cana de açúcar é muito bem cuidado, com uma grande tecnologia Inclusive a biotecnologia em termos de controle biológico é uma das mais avançadas do mundo. Já o eucalipto está equivocado, é aquela visão de fazer barato, de indústria gigantesca, de sugar ao máximo do solo e o abandonar, ir para outra área. Isso com os anos vai melhorando.

Aí tem outras coisas: o eucalipto cresce muito rápido, mais até que o bambu. Daí você pega o eucalipto e coloca numa região com índice de pluviometria baixo, é lógico que ele vai extrair a umidade do solo. Aí mais uma vez é um erro do ser humano de plantar no lugar errado. Mas enfim, isso tudo ainda é muito melhor do que você fazer um pasto. Um sistema florestal, ainda que em monocultura garante algumas coisas como a matéria orgânica se decompondo, sombreamento, evita a erosão, protege muito mais o sistema hídrico do que um boi pastando. Isso tudo é muito relativo. Tem muito ecologista que é contra o eucalipto, mas na verdade o eucalipto gerou riqueza pro Brasil demais, e acho que as pessoas deviam contabilizar isso também.

Agora o bambu é totalmente diferente do eucalipto. Você planta o bambu, e nunca mais você pode ir embora do terreno senão você não vai ter bambu. Você vai ter gasto com mão de obra desde o inicio, e sempre. Quando chegar no 70 ano, aí que você vai ter mão de obra, porque vai ter que cortar, desgalhar, limpar, triturar... Então ele é um fixador do homem do campo, o que é um ponto positivo para a ecologia e para o social, mas negativo para o empresário. As pessoas querem produzir sem gente hoje em dia, então os investidores ele fogem disso hoje em dia. Mas ambientalmente falando o bambu é espetacular porque você cria um bosque perene. E já foi provado cientificamente na Colômbia que o bambu devolve a água ao terreno, inclusive transferindo umidade na época da seca, armazenando água dentro dos colmos, que serve para em períodos de seca, os bambus manterem seu desenvolvimento. O sistema todo acaba ficando muito mais úmido, sendo assim, o bambuzal tem um papel hídrico importantíssimo nas bacias hidrográficas e na regeneração, porque é uma mata ciliar que cresce muito rápido em cobertura vegetal, coisa de 3 anos. Então o bambu forma uma barreira física, tem o papel de regeneração hídrica da bacia. Sendo que sua extração sempre é seletiva, você nunca verá um bosque totalmente cortado, a chuva nunca cairá diretamente no solo, sempre tendo assim uma reposição de matéria orgânica e regulação hídrica e de erosão. Não dá para comparar com eucalipto, ganha de longe. Mas pode ser encarado como monocultura também. O ideal é mistura com babaçu, dendê, etc., como estivemos fazendo em alguns projetos. Alguns deles como o Guadua tendem a suprimir algumas espécies, mas ainda assim, trata-se de uma floresta, tem biodiversidade, etc. O Mossô também, quando se decompõe, as folhas cria-se inibidores de germinação de sementes de outras espécies, em geral tudo o que fica abaixo dos Mossôs não resiste, são bambus supressores. 


\section{TRATAMENTOS}

P.N. - Quais tratamentos recomendados para ser utilizados na construção civil para habitação popular tendo em vista a produção local de baixo investimento? Octoborato por imersão? Autoclave?

D.C. - A autoclave é cara e a tendência é acabar. Hoje toda a minha linha de revestimento interno, mais de $60 \%$ dos produtos é octoborato. Eu cozinho com octoborato em geral, só uso a autoclave quando são peças estruturais acima de $3 \mathrm{~m}$, para dar garantia. Sempre que possível entro nos projetos usando boro. Não pretendo usar mais o CCA, temos que tirar química pesada, metais pesados, coisas que podem detonar a saúde das pessoas. É um risco, você faz uma obra, corta um pedaço, joga fora, alguém vai lá e põe no fogão dele, liberando arsênico... Você está serrando e lixando inalando aquilo, tem que pagar adicional por periculosidade para quem trabalha com isso, que está sempre exposto...

P.N. - E a durabilidade é muito diferente?

D.C. - Totalmente, o octoborato é um sal solúvel em água, o CCA é insolúvel até em petróleo. Nada tira o CCA.

P.N. - Tem que ter contato zero com a água para o uso do octoborato então.

D.C. - Sim, mas aí é que está, o projeto colombiano mostra que o bambu tem que estar protegido, a famosa proteção pelo desenho, como se diz lá na Colômbia. Isso é muito importante que se desenvolva na cultura. O bambu é "pra dentro".

Lá eu uso cozimento em solução a $80 / 90$ Cㅡㄹ ebulindo com octoborato. Porque aí faço em duas horas. A imersão natural leva cerca de 4 dias. Tudo isso baseado em pesquisa tecnológica da universidade da Colômbia. 

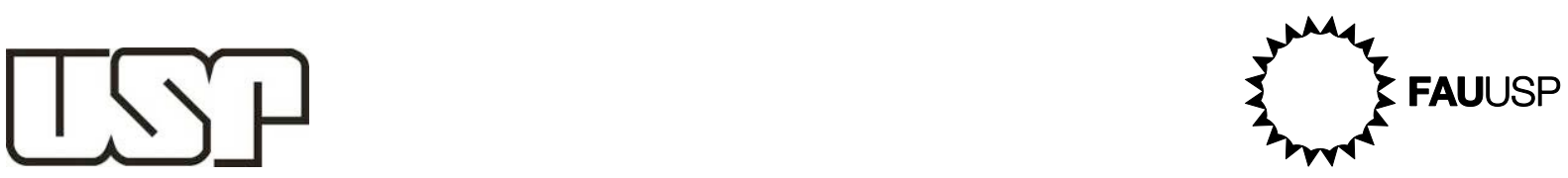

Universidade de São Paulo

Faculdade de Arquitetura e Urbanismo

Curso de Pós-graduação

Entrevista Arquiteto Simón Vélez - Levantamento de dados primários

Bogotá, 22 de Fevereiro de 2012.

\section{INTRODUÇÃO}

Paula Noia - Sabemos que é filho de arquiteto e que tem uma família de tradição construtiva, mas gostaria de saber um pouco sobre sua formação arquitetônica, suas influências e referências.

Simón Vélez - Bem, meus avôs eram construtores. Não existia então a arquitetura então, mas um deles trabalhava no que equivale a ser arquiteto, fazia urbanizações e construía com madeira e com guadua e bahareque ${ }^{53}$. Aqui o que se chama bahareque é universal, bahareque pode ser muitas coisas. Qualquer arquitetura vernacular de qualquer parte do mundo usa bahareque. No Japão, na Alemanha, na Colômbia... São fibras vegetais verticais e horizontais e terra, pode ser com aglomerados, com fibras como palha, depois com cal e pintura, com paredes lisas. Enfim, isso existe em todo planeta.

P N-Sim, seria um tipo de taipa no Brasil, o pau-a-pique.

$S V$ - Sim. Aqui costumam classificá-la como algo nativo, autóctone, mas na verdade é uma forma natural de se construir. Como um pássaro construindo seu ninho, os pássaros em qualquer parte do mundo tem seus ninhos parecidos.

Meu avô era grande proprietário de terras e seu hobbie era fazer casas em suas fazendas, era o que mais gostava. Então digamos que tinha uma grande experiência como construtor. Já meu pai estudou arquitetura nos Estados Unidos, porque aqui não existia ensino superior

53 Sistema construtivo constituído a partir de trama de bambus com revestimento de reboco cimentício ou em terra. Muito empregado desde épocas remotas para a construção de habitações indígenas na América. 
em arquitetura. Estudou primeiro engenharia aqui em Bogotá, na Universidad Nacional, mas como queria ser arquiteto, iniciou o curso de arquitetura nos Estados Unidos. Era a época da guerra e tinha muitos professores alemães da época da Bauhaus. Então meu pai foi o primeiro arquiteto na Colômbia formado com os parâmetros da Bauhaus. Foi o primeiro arquiteto moderno, mas não ficou conhecido pois nunca saiu do povoado que nascemos, próximo à Manizales. Então fazia lá a arquitetura moderna como se entende por arquitetura moderna. Eu nasci em uma casa realmente moderna, mas isso não me interessa. Havia rampas, pés-direitos duplos, era uma casa muito bonita. Mas também era uma casa estranha. Eu tenho 63 anos e nasci aí, ou seja, foi feita há 65 anos. A primeira casa moderna que existiu na Colômbia foi feita por ele. E também haviam outros arquitetos que vieram do Chile e da Europa, mas não eram tão modernos quanto meu pai, que foi responsável pela vanguarda da Bauhaus aqui. Então eu nasci em uma casa dessas, por isso não tenho nenhum interesse nisso, não me agrada. Não é que não me agrada, me agrada, mas não quero fazer isso, não me interessou. Me interessou muito mais a arquitetura de casas de campo que fazia meu avô oligarca, ser um arquiteto rural. E me interessei pelas madeiras, aqui a princípio não há uma cultura florestal, saímos de caça na floresta. E as madeiras de floresta que não tem cultivo não são fáceis de aproveitar. E acidentalmente me interessei pela guadua.

$P N-E$ como se deu isso?

SV - Um cliente me pediu que projetasse uma estrutura para cavalos e tinha que ser em guadua. E eu nunca tinha trabalhado com guadua. Eu nasci dentro de um guadual praticamente, mas a guadua para nós tem o estigma da pobreza. As casas antigas eram feitas em guadua igualmente, e em madeira e bahareque, mas não se mostrava muito a guadua, ela ficava oculta, mas eram feitas de guadua. Manizales foi feita assim, e sofreu muitos incêndios, durante três ou quatro anos aconteceram quatro incêndios enormes e ninguém mais quis construir com a guadua. Era uma cidade rica, o negocio do café iniciou-se ali, e havia muito negócio de ouro também. E por ser uma cidade rica, a reconstruíram em concreto. E foi tão alto o custo de reconstruí-la em concreto que aí chegou a economia dessa cidade. Fizemos a maior igreja de concreto do mundo. E todas as famílias ricas, com seu fanatismo religioso, arruinaram-se fazendo essa catedral.

PN - Isso é em Pereira?

SV - Não, Manizales. Em Pereira existe uma mas é de madeira e é belíssima, e não se queimou nunca. Estiveram reformando a catedral de Pereira e me pediram que fizesse uma catedral provisória em guadua. E essa igreja a refiz em Cartagena, em minha fazenda, em meio a uma lagoa. Mas não é católica, nem cristã, é um templo sem religião. 
$P N$ - Eu ouvi dizer que quando a igreja foi desmontada de Manizales pediram para refazê-la não?

SV - Não, na verdade o terreno era emprestado de uns judeus. Foram muito generosos, emprestaram, não cobraram e era um lote muito valioso, na Praça Bolívar. E também a igreja foi feita de maneira provisória então não foi devidamente tratada contra os insetos. Se não a demolissem ela ia cair por si só.

$P N-E$ quanto tempo funcionou a igreja?

SV - Um ano e meio.

$P N-E$ sem tratamento quanto tempo a mais acredita que duraria?

SV - Um ano a mais. Porque a guadua sem tratamento é comida pelos insetos.

PN - Bem, falando um pouco sobre a arquitetura vernacular, acredita que pode representar uma produção que represente essa arquitetura vernacular por estimular o uso de uma técnica local, com matérias-primas locais e mão de obra local ou acredita que essa associação seja estigmatizada?

SV - Não, me agrada ter meu trabalho associado à arquitetura vernacular. Na verdade nunca o pensei assim por que se trabalha de maneira inconsciente. Mas prefiro que me comparem com o vernacular do que com o contemporâneo. Além disso, o que é o moderno? A palavra moderno já é uma palavra antiga. Nos classificamos em definições absurdas, e o moderno é o que já foi moderno. O moderno não tem mais a conotação atual, o que meu pai fazia para mim é antiguidade. Deve-se respeitar o significado da palavra moderno. É como se disséssemos que o "amanhã" ou o "hoje" começassem a ter significados diferentes. A palavra "futuro" tem que significar "futuro" a palavra "hoje" tem que continuar significando "hoje". E a palavra moderno não pode estar descrevendo antiguidades que vem de um passado que para mim já é remoto.

Eu não sou fundamentalista ambiental, mas isso se tornou uma religião que não tem volta. Ou seja, não penso que eu esteja aqui para salvar o planeta e ao planeta não importa o que fazemos nós seres humanos. O dano que estamos causando não é ao planeta mas sim a nós mesmos. E não quero representar isso como um dano ao planeta, o planeta é totalmente indiferente. Qualquer porcaria que o ser humano faça, ao planeta é totalmente indiferente. Talvez até se continuássemos a fazer o que fazemos o planeta fique mais feliz, pois vamos acabar com nós mesmo mais rápido...

PN-Sim, vamos parar de aborrecer o planeta... 
SV - Sim... Uma explosão de um vulcão, um meteorito, existem coisas geológicas que geram cem vezes mais impactos que todas as atrocidades juntas do ser humano. Antes de acabar com o planeta acabamos com nós mesmos. De qualquer forma, isso está gerando uma consciência do uso dos materiais naturais que me agrada. E por sensibilidade, decidi que me agradam as coisas naturais. Por ser hippie. Sou um hippie velho pois pertenço a essa geração que foi a primeira que teve uma atitude frente à natureza e que hoje gera todo esse fundamentalismo ecológico que não gosto. Não gosto de qualquer coisa que pareça uma religião. Ou seja, se trabalhar com materiais naturais fosse ruim para o planeta eu estaria fazendo também.

PN - Sim, eu li em uma entrevista sua que dizia que a sua produção arquitetônica não era uma questão de salvar o planeta mas sim de fazer justiça social e de ressaltar as grandes qualidades materiais do bambu.

SV - Gosto muito das coisas feitas à mão, e as coisas feitas à mão e não em série tem um benefício social. Não é que eu seja um justiceiro social. Por coincidência agora eu estou nas tendências que supostamente agora estão se tornando de vanguarda. Mas o que eu faço, e o faço há muitos anos, a academia nunca considerou importante. Então, aqui queremos demonstrar que não somos pobres, que pertencemos ao primeiro mundo então os exemplos que temos para mostrar são de arquiteturas de concreto, tijolos e aço que não me interessa. Sinto que aqui as fazem de melhor qualidade, melhor do que no resto do mundo, mas essa arquitetura não me interessa. Isso não porque ela tem um custo ambiental ou social, mas porque não. Não me interessam os materiais sintéticos para ir à lua ou para competências esportivas, porque tem alguns materiais prodigiosos. O high-tech nos materiais naturais é a guadua, que tem as propriedades estruturais que aproximadamente tem os materiais de altíssima tecnologia, e o fazem grátis. E geram rendimentos a um campesino, ao contrário da arquitetura mineral que somente produz rendimentos aos grupos econômicos que são imensamente ricos. Quando se emprega o uso do aço, além do custo ambiental , que não me importa, está o custo de todos os combustíveis para a geração do material, sendo que a guadua a natureza a faz grátis.

Digo que como arquiteto, deve-se ser um pouco mais vegetariano. Nos tornamos muito trogloditas. Quando se faz uma casa de piso de cimento, estrutura de cimento, parede de cimento, de tijolos vidro e ferro, você esta vivendo como um homem das cavernas, entre minerais somente. E nós homens não viemos das cavernas, viemos das árvores, por isso temos polegar opositor, nossa anatomia é arborícola e não cavernícola, caso contrário teríamos garras para escavar. Isso é um mito histórico, nunca fomos cavernícolas, jamais. Um ser humano que se enfia em uma caverna morre, pois nosso pior inimigo é a umidade, não aguentamos tocar o solo quando dormimos. 
Então a arquitetura tinha que ser mais vegetariana. Eu não sou fundamentalista vegetariano, eu como carne. Deve-se ter um equilíbrio na arquitetura, componentes carnívoros e componentes vegetarianos. O carnívoro seria componentes como o concreto, o aço, dos quais eu gosto muito, mas deve-se tentar o equilíbrio entre os materiais.

Estamos em um país de terremotos. Construir com o código sismo-resistente em um país de terremotos é exageradamente caro. Uma família pobre não tem nem com o que fazer a fundação de uma habitação sismo-resistente pensando em termos de concreto. E quando constrói-se exclusivamente em madeira há uma coisa pior que os terremotos que são os incêndios. Construir totalmente "vegetarianamente" pode ser um perigo quando há grandes aglomerações pois podem provocar incêndios gigantescos. Isso já se passou em Los Angeles, em Tokyo, em Manizales, de onde sou, e isso é pior que um terremoto. Então minha proposta é que a arquitetura tenha o esqueleto flexível em qualquer fibra vegetal, ou seja, madeira ou bambu e, o revestimento, a pele das construções que seja em cimento, pois o cimento não se queima. Que o compromisso estrutural seja feito por materiais flexíveis e que o compromisso contra o fogo seja feito pelos materiais minerais incombustíveis. Essa casa é um exemplo primitivo de isso. ${ }^{54} \mathrm{~A}$ estrutura é madeira mas a pele é cimento. Esse piso que está vendo está sobre cimento, se há um incêndio o cimento seria um isolante. Essa casa não sofreria incêndio nem terremoto. Essa cultura não conservamos aqui, nós os países pobres somente pensamos em concreto e concreto e concreto. E quando acontecer um terremoto forte aqui, será apocalíptico. O concreto ainda que bem construído também colapsa. No Japão também falharam estruturas muito sofisticadas em concreto enquanto que com a madeira não acontece nada, o problema da madeira é o incêndio. Deve-se ter um equilíbrio entre muitos materiais, por razões de segurança.

Então nunca me propus a ser arquiteto urbano, tenho muitas coisas a dizer, e tive a oportunidade de fazer coisas urbanas de impacto grande. Já estou um pouco velho mas talvez ainda consiga fazer algo com uma proposta de interesse social com isso que estou dizendo: de materiais flexíveis na estrutura e materiais incombustíveis nos revestimentos. Poderia se fazer até sete, oito andares em estrutura de madeira, para não se construir com tão baixa densidade que implica em extensão de serviços de infraestrutura e transporte. Aqui mesmo, por exemplo, tem um projeto da prefeitura que é exigir que a cidade volte ao centro de baixíssima densidade. Ali cabe outra cidade gigantesca e já tem as vias, os serviços, e pode-se vir a pé ao principal empregador da Colômbia que é o governo, que fica aqui. $O$ país se administra nesse centro.

PN - Sim, há muito potencial de adensamento em Bogotá.

\footnotetext{
${ }^{54}$ Casa de Simón Vélez em Bogotá, com estrutura em bambu e revestida em cimento.
} 
SV - Aqui só pensa-se em estender e estender a cidade para enriquecer urbanizadores que compram terras baratíssimas. A cidade tem que sustentar sobre si mesma, demolir-se e reconstruir-se sobre si mesma sempre. Há cidades muito antigas que arqueólogos conseguem distinguir 7 a 8 "camadas" de cidade, uma em cima da outra. Isso tem que continuar acontecendo assim. Paris medieval, belíssima, foi demolida por Napoleão e reconstruída e se continuou belíssima.

Agora já não deixam mais fazê-lo mas se deveria exigir que as cidades fossem se reciclando, demolindo e reconstruindo sobre elas mesmas. Me parece que a arquitetura moderna, desse moderno pré-histórico que falei, é tão feia que felizmente proibiram de seguir fazendo essas porcarias...

PN-Sim... Bom, falando agora um pouco sobre o reconhecimento do bambu atualmente no mundo, muita coisa mudou na relação do material de construção bambu com a Colômbia e com o mundo depois do projeto do pavilhão Zeri em Hannover e em Manizales?

SV - Acredito que o que foi feito em Hannover não teve nenhum impacto, porque a entidade que a fez é de reputação duvidosa. O pavilhão não teve tanto reconhecimento assim. Para mim, fazê-lo foi muito importante, e ele existe em Manizales. Há dois anos fiz uma exposição de uma estrutura mais interessante, que foi o pavilhão da Índia em Expo Xangai. Fiz a engenharia de um grande domus isso foi bem interessante mas ficou o edifício mais feio que vi em minha vida. A estética indiana é muito peculiar. $O$ antigo da cultura indiana é belíssimo, mas a arquitetura contemporânea indiana, para a nossos padrões é muito estranha. Impossível encontrar algo mais feio. Para eles é algo muito bonito, eles são milhões de habitantes e essa é a estética deles, tem todo o direito, mas é uma estética que eu não compreendo. Isso me deixou muito frustrado também pois tive oportunidade de estar nas duas grandes exposições universais e em nenhuma das duas houve nenhuma transcendência. Mas de todo modo, o tema dos materiais naturais está se difundindo com muita força. Muitíssima. Então, parte do meu prestígio se diria que coincide com essa avidez que existe agora no mundo desenvolvido em explorar os materiais naturais.

PN-Sim. E seu trabalho também contribui muito para essa corrente de pensamento, não?

SV - Não sei. Eu não sou intelectual, nunca fui acadêmico e nunca escrevo. Mas sim, houve muitas palestras, permanentemente estou viajando convidado a dar conferências. Acabo de voltar da Indonésia onde estive falando sobre como construir com bambu e fazendo um trabalho prático em Bali. Estou frequentemente viajando, mas na Colômbia nunca dei conferencias.

$P N-N u n c a ?$ 
SV - Não. Aqui não os interessa o que eu faço. Aqui o prestígio está no concreto e nos tijolos, no Salmona ${ }^{55}$. Para mim, Salmona não me diz nada, ou seja, aqui existiu uma bonita tradição de se trabalhar com o tijolo cerâmico, e o fazem muito bem, mas a mim isso não interessa. Não porque eu não ache bonito, mas porque não é meu espaço. Poderia fazê-lo e seria muito viável para mim, faria uma arquitetura com essa linguagem sem nenhum problema pois se você é bailarino, você dança qualquer ritmo sem nenhum problema, mas esse ritmo não me interessa.

PN - Sim. E você acredita que essa não aceitação desse sistema construtivo dentro da Colômbia...

SV - Não, existe uma aceitação. Digamos que eu faço muitas casas de gente rica. Há uma elite econômica e cultural que aprecia meu trabalho. E fiz uma vez um trabalho de habitações de interesse social, um pequeno exemplo de cem casas e cometi muitos erros mas também fiquei muito contente com o resultado, pois fiz as casas que haviam sido as mais econômicas da história da construção na Colômbia, e as mais dignas. E gostaria de fazer mais projetos de habitações de interesse social mas não tenho tempo para dedicar-me à corrupção. Não me importa a corrupção, isso nunca se acabará, mas isso demanda muito tempo. Então se houver a possibilidade de fazer um exemplo interessante sem corrupção de projeto de interesse social, gostaria muito de fazer.

$P N-E$ onde fica esse projeto de interesse social que fez?

SV - Fica próximo a um clube de golf que também fiz que se chama Peñalisa. Então, como já haviam casas de gente rica em bambu, as pessoas pobres aceitaram que se fizesse suas casas também em bambu, pois havia um exemplo já feito. Mas isso evoluiu mal e não estou contente com como ficou o projeto. Então estou pronto para fazer outro projeto de interesse social que possa ter um melhor impacto.

$P N-E$ onde fica esse projeto?

SV - Fica em Girardot em um povoado que se chama Ricaurte. Fica aqui, baixando o Rio Magdalena, três horas em carro.

PN - A guadua está recém-aceita no código de construção colombiano...

SV - Sim, iam proibí-la, me inteirei e falei com o presidente que era o Uribe, de quem não gosto muito, mas ele conseguiu parar a lei e pediu para que eu redigisse o capítulo sobre Guadua. Mas como não sou bom em escrever, contratei um engenheiro que a redigiu, o Eng. Luis Felipe Lopez, e ele trabalhou comigo.

\footnotetext{
${ }^{55}$ Rogelio Salmona, mais notável arquiteto moderno colombiano.
} 
PN - Então você tem uma relação direta com essa inclusão da guadua...

$S V$ - Sim, isso foi obra minha pois fui eu quem falou com o presidente e o presidente fez parar a lei, o que foi importante pois até esse ano, não se permitia nem se proibia, estava no limbo, mas possivelmente iam proibir o uso.

$P N$ - Então agora o que considera como obstáculos ainda existentes para a prática da construção em guadua?

$S V$ - Os fundamentalistas ecológicos. Existe uma lei que alega que a guadua esta em vias de extinção e isso é falso. O que a faz ficar em vias de extinção é uma lei como essa, pois ninguém cultiva a guadua porque esta proibido cortá-la. E eu jamais pude comprar a guadua do dono da plantação, porque a corrupção não permite. Existe uma lei tão absurda que proíbe os donos de fazenda de cortar guadua, necessitam de um estudo de impacto ambiental que vale uma fortuna e não importa a quantidade de material que vai cortar, uma, cem ou mil, necessita do mesmo maldito estudo. Ao passo que os que cortam a guadua ilegalmente tem essas permissões no bolso. Então ao dono da fazenda lhe pagam 200 pesos $^{56}$ por uma guadua que mede mais de $20 \mathrm{~m}$. Eu pago 20 mil pesos $^{57}$ por essa guadua e a mim não interessa que seja mais barato, já é muito barato. Mas me interessaria que esses 20 mil pesos chegassem ao dono da fazenda, ao campesino e não a um corrupto intermediário. E é uma corrupção muito pequena, de pequenos funcionários, mas a culpa é da lei, não deles mesmos. Então se algum dia consigo ter mais importância política, a usarei para a eliminação dessa lei absurda e que a guadua seja um material agrícola e não como dizem, uma espécie em vias de extinção. Esses ambientalistas corruptos são uma praga, esses tipos Greenpeace que nos aborrecem com tanta besteira. Toda essa gente o que fazem é fomentar corrupção e fazer com que os grandes empresários odeiem os temas ambientais, pois só os incomodam com esses temas para arrancar-lhes dinheiro. É um motivo de corrupção abominável, detestável e seus personagens são sinistros. Os aiatolás da ecologia, mas corruptos, ou se não são corruptos, geram consequências corruptas, que é a mesma coisa.

Te mostro o último trabalho urbano que fiz. A primeira consequência de que já não está proibido construir com guadua por causa do código é que me pediram um terminal de transportes em Cali muito grande. São vinte mil metros quadrados o que para a escala que trabalho é muito grande. E como há o código não é mais ilegal. Então é um tipo de projeto que já pode obter todos os protocolos de licença.

Então, mas o que dizia que fiz na Índia, o grande domo: fiquei muito frustrado porque o edifício é muito feio. Estão estou fazendo-o outra vez aqui sem indianos. Já estamos fazendo

\footnotetext{
${ }^{56}$ Equivalente, no momento da entrevista, a 20 centavos de real $(R \$ 0,20)$.

${ }^{57}$ Equivalente a vinte reais $(R \$ 20,00)$.
} 
a fundação mas tivemos muitos problemas. Mas vai ser uma grande estrutura que está aí, se chama Mundo Aventura. Será muito similar ao pavilhão de Xangai mas sem a estética hindu. Na China, que foi feito com Mossô, que não é tão forte, consegui fazer um diâmetro de 36 metros livres. Mas com a guadua que é muito mais estrutural posso chegar a $50 \mathrm{sem}$ problemas o Panteão em Roma que é de pedra tem 41, em bambu é muito mais fácil. E se consigo fazer maior, posso chegar a 70 ou $80 \mathrm{~m}$. Na medida que se vai avançando a escala real com os protótipos.

$P N-E$ as conexões que vem fazendo nessa obra seguem sendo com preenchimento em argamassa?

$S V$ - Sim. Até que inventem uma melhor eu continuo usando essas. Mas tem que ser melhor e mais barato.

PN-Difícil...

$S V$ - Sim, o cimento é muito barato.

$P N-E$ a norma colombiana está exclusivamente com esse tipo de união?

SV - Sim, quem a fez foi um engenheiro, mas contratado por mim. Mas está aberta para que alguém que apareça com outra técnica construtiva a incorpore na norma. Eu fiz uma primeira aproximação a uma técnica construtiva mas quando existir mais gente trabalhando com o mesmo vão encontrar outras maneiras. Além disso o que menos tem futuro é a forma com a qual eu trabalho o bambu, em seu estado natural. O futuro é a laminação, retirar lâminas prensá-las e com isso fará o que queira. Inclusive estou como sócio de uma pequena indústria que estamos montando em Manizales e o grande problema é que a Guadua é um cultivo ilícito. É o único cultivo ilícito que não temos que pedir permissão aos americanos para que nos deixem legalizá-la. Porque como disse, os ambientalistas tem a guadua como espécie em vias de extinção, para administrar a corrupção. São todos uns fundamentalistas, vão proibir os touros, vão nos proibir de comer carne e que já proibiram a todos de fumar, que importa se vão todos morrer de câncer?

PN - Uma última questão: minha pesquisa tem uma premissa de colocar o bambu como material que promove uma articulação social, por possuir um baixo custo de produção, com o qual as pessoas podem se apropriar de todo o processo produtivo, desde o manejo da plantação, tratamento, até a execução de casas, tendo assim um enfoque muito social. Acredita no potencial do material nesse sentido?

SV - Sim. Nenhuma planta na terra cresce mais rápido do que os bambus. Estabelecer uma floresta de bambu leva uns 10 anos e estabelecer um bosque de madeira leva 40 . E numa plantação de madeira, ao longo desses trinta anos você emprega pouquíssimas pessoas em 
sua manutenção que se faz sobretudo com maquinário. Enquanto que uma plantação de bambu, se você a projeta no tempo apos 10 anos você já inicia a colher, e nenhuma planta cresce na velocidade de um bambu. A guadua é o bambu mais preguiçoso dos bambus gigantes que existe pois cresce somente $12 \mathrm{~cm}$ por dia, quando já tem seu diâmetro definitivo. Esse diâmetro se obtém no sétimo/oitavo ano da plantação, que a cada ano dá um diâmetro maior. Se for para esterilla ${ }^{58}$, que é o grande futuro para fazer laminados, o bambu é mais jovem, não pode ser adulto que é o negócio que estou fazendo agora. $A$ resistência é a mesma, mas o ataque contra insetos que é maior quando jovem mas de todas as maneiras temos que tratá-las. Então em um hectare de área produtiva de bambu, se você projetá-la no tempo, deve colher 20 a $25 \%$ da plantação de bambu a cada ano. Você tem nos 12 meses do ano gente ocupada fazendo a extração de bambu, muito diferente de um bosque solitário por 40 anos.

Além disso, os usos do bambu são infinitos. Como comida: a guadua origina deliciosos brotos de bambu, tem que cozinhá-los como qualquer bambu. Na Ásia tropical todos os dias se comem brotos de bambu, como comemos batatas. Para os têxteis é prodigioso, o bambu origina tecidos maravilhosos. Para fazer laminados, são infinitos os usos, o plywood, com seu tamanho standard de 2,40 X 1,90 teve uma indústria devastadora em países como Colômbia por arrasarem bosques extraordinários que foram arrasados sem reflorestamento, locais com árvores de umidade, muito difícil de se replantar. Fizeram-se devastações ambientais terríveis todas baseadas em corrupção. $O$ maior dano não é a natureza mas sim à moral humana. E com o bambu você pode abrir mão desse tipo de indústria, não necessita nunca mais incomodar uma floresta dessa, pois você pode fazer esses laminados com guadua a uma velocidade que nenhuma outra planta na terra cresce. A biomassa que você consegue em uma área projetada com bambu é muitíssimas vezes maior do que a biomassa produzida em uma floresta de madeira. Também tem a questão da captura de CO2: nenhuma planta na terra produz maior captação de $\mathrm{CO} 2$ do que os bambus.

Para a construção, os usos são infinitos, para têxteis, para papel. Temos esse colonialismo cultural horrível pois somente temos papéis de coníferas, que importamos do Canadá. A Colômbia deveria produzir seu próprio papel com celulose de bambu, com um bambu apropriado, não necessariamente a guadua. Nossa indústria de papel deveria ser em bambu, e nossa indústria de madeira deveria ser em bambu, pois é o recurso florestal mais valioso que existe na Colômbia. E os engenheiros florestais reataram uma lei florestal que passaram uns cinco anos escrevendo-a e a palavra guadua nesse gigante tratado não aparece nenhuma vez! E esse é o recurso florestal mais valioso da Colômbia. Esta mesa que tenho aqui em madeira pode-se fazer em bambu, sem ter que devastar um bosque. Ao bosque

58 Esterilla é o colmo do bambu aberto longitudinalmente e planificado, formando uma esteira de aproximadamente 35 centimetros de largura. 
convém uma entressafra natural, mas nós humanos não sabemos fazer coisas racionais. Se nos dão licença para explorar uma floresta, chegam com maquinaria pesada e arrasamos tudo. Não sabemos fazer uma extração seletiva e delicada. Este piso de madeira é um crime ambiental. Isso saiu de uma floresta tropical e ninguém o esta replantando, este piso deveria ser de bambu. Estas cadeiras poderiam ser de bambu com esta mesma forma, fazendo-a laminada. 